\title{
Optimizing Soil and Water Management in Dryland Farming Systems in Cabo Verde
}




\section{Thesis committee}

\section{Promotor}

Prof. Dr Coen J. Ritsema

Professor of Soil Physics and Land Management

Wageningen University

Prof. Dr Violette Geissen

Privatdozent at INRES, University of Bonn, Germany

\section{Co-promotor}

Dr Luuk Fleskens

Assistant professor, Soil Physics and Land Management Group

Wageningen University

\section{Other members}

Prof. Dr Jakob Wallinga, Wageningen UR

Prof. Dr Celeste Coelho, University of Aveiro, Portugal

Prof. Dr Thilo Streck, University of Hohenheim, Germany

Dr Gudrun Schwilch, University of Bern, Switzerland

This research was conducted under the auspices of the Research School for SocioEconomic and Natural Sciences of the Environment (SENSE) 


\title{
Optimizing Soil and Water Management in Dryland Farming Systems in Cabo Verde
}

\author{
Isaurinda dos Santos Baptista Costa
}

Thesis

submitted in fulfilment of the requirements for the degree of doctor at Wageningen University

by the authority of the Rector Magnificus

Prof. Dr A.P.J. Mol, in the presence of the

Thesis Committee appointed by the Academic Board

to be defended in public

on Tuesday, 10 May 2016

at 4 p.m. in the Aula. 
Isaurinda dos Santos Baptista Costa

Optimizing Soil and Water Management in Dryland Farming Systems in Cabo Verde, 189 pages.

PhD thesis, Wageningen University, Wageningen, NL (2016)

With references, with summary in English

ISBN 978-94-6257-736-7 


\section{Dedication}

I dedicate this last degree of my academic training to the memories of two important people in my life that cannot share this special moment with me. One is my late, beloved father, Antão Pedro Baptista (Cuca), a man that I always admired for his intelligence and general knowledge, a land lover that did not have the means to pursue a high education. He always encouraged his children to study and was always proud of their accomplishments. The other is my brother, Adriano Baptista, a very bright young man that would have a promising future ahead of him if an accident had not taken his life at the age of 21 . Were they alive, they would be very happy for me. May they rest in peace!

\section{Dedicatória}

Dedico este meu último grau académico em memória de duas pessoas que foram muito importantes na minha vida e que não podem partilhar comigo este momento importante. Uma é o meu falecido, amado pai (Antão Pedro Baptista - Cuca), um homem cuja inteligência e conhecimento geral, eu sempre admirei, um apaixonado pela terra que não teve a oportunidade de prosseguir uma formação superior. Ele sempre encorajou os filhos a estudar e sentia-se orgulhoso dos seus sucessos. A outra pessoa é o meu irmão Adriano Baptista, um jovem que teria um futuro promissor não fosse um acidente a ceifar-lhe a vida aos 21 anos de idade. Se estivessem vivos, por certo, estariam muito felizes por mim. Que descansem em paz! 



\section{Table of contents}

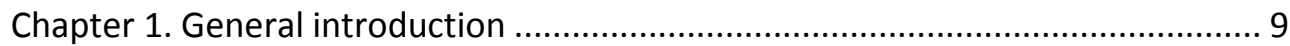

Chapter 2. Sustainable land management strategies in Cabo Verde and their impacts on livelihoods: an overview from the Ribeira Seca Watershed.

Chapter 3. Improving rainwater-use in Cabo Verde drylands by reducing runoff and erosion. 53

Chapter 4. Effect of integrated water-nutrient management strategies on soil erosion mediated nutrient loss and crop productivity in Cabo Verde drylands .83

Chapter 5. Assessing the biophysical impact and financial viability of soil management technologies under variable climate in Cabo Verde drylands: the PESERA-DESMICE approach

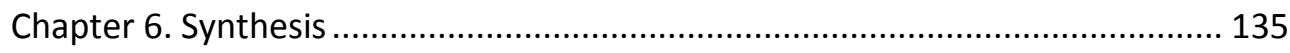

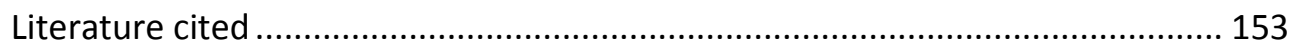

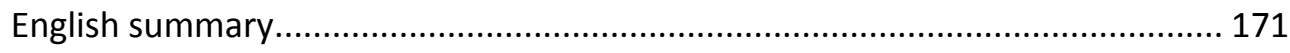

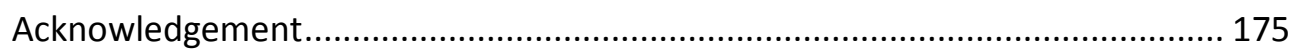

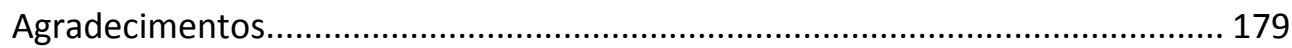

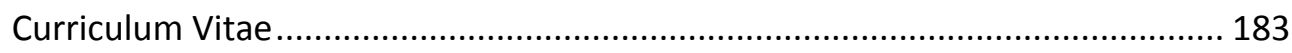

Certificate of the Netherlands Research School for the Socio-economic and Natural Sciences of the Environment (SENSE) 



\section{General introduction}




\subsection{Dryland soil degradation due to runoff and nutrient depletion: impact on food production and sustainable land management}

Worldwide, drylands occupy approximately $41 \%$ of the land surface area and support the livelihoods of about 2 billion people (Middleton et al., 2011; UNCCD, 2012; Reed et al., 2015). More than $20 \%$ of these drylands are being affected by soil erosion and desertification (Millennium Ecosystem Assessment, 2005; WSR, 2015). Every year the world is losing approximately 24 billion tons of fertile top soil because of wind or water erosion (Ehlers et al., 2013), which poses a great challenge for sustainable development. Along with climate change, population growth and changing consumption patterns are putting additional pressure on both land and water resources. The increasing demand on the finite soil resources for the food, feed, fibre and fuel needs of the growing population exacerbates the problems of soil degradation and desertification (Lal, 2009). Cabo Verde is part of the world's drylands and experiences its share of all these problems, thus making it ideal as an area to study how to adapt to and/or mitigate these problems.

Due to the link between soils and other natural resources, soils need to be considered as an integral component of the water, energy and food security connexion. One of the greatest threats in arid, semi-arid, and dry sub-humid areas is land degradation through soil erosion by water (UNCCD, 2007) which results from various factors, including climatic change and human activities. Land degradation occurs because drylands are vulnerable to overexploitation, inappropriate land use, nutrient depletion, and climate change (Schwilch et al., 2012). It deprives the land of its soil, biodiversity, and productivity potential, leading to long-term (sometimes-irreversible) deterioration of the functions that ecosystems provide (Abdi et al., 2013). For example, low and declining soil fertility are recognized as major factors underlying low crop productivity in sub-Saharan Africa (WSR, 2015). And it is estimated that the potential loss in grain yield due to the impact of climate change is about $5 \%$ for each degree Celsius of global warming (Lobell et al., 2011). Thus, integrating climate change adaptation and mitigation may ensure food security and reduce agriculture's ecological footprint. Adaptation to climate change is a priority to pursue mitigation, but it should bring benefits without increasing costs and risks (Jarvis el al., 2011). Reversing land degradation is essential to improving water productivity, nutrient availability, and rural livelihoods in low-yielding dryland farming systems (Zougmoré et al., 2003; Schwilch et al., 2012).

Water management in agricultural drylands can strongly influence land degradation. Improving rainwater-use efficiency (RWUE), which measures the biomass or grain yield produced per increment in precipitation (Hatfield et al., 2001), by properly managing the 
land through use of sustainable land management (SLM) techniques and approaches benefits not only water productivity, but also soil conservation (Bossio et al., 2010). Considering that soil erosion by water is one of the greatest degradation threats in drylands, evaluating land management techniques that reduce erosion and optimize both water and soil management is key for sustainable farming in these areas.

Current scientific debates regarding how to sustainably increase food production and deal with land degradation consider two closely related and complementary approaches: sustainable intensification (SI) and climate smart agriculture (CSA). SI aims to increase food production from existing farmland while minimizing pressure on the environment, also requiring consideration of economic and social priorities (Campbell et al., 2014). As this approach is a policy related goal for several national and international institutions, to operationalize $\mathrm{SI}$ in the drylands it is of utmost importance to apply the concepts of vulnerability and resilience (Campbell et al, 2014; Robinson et al., 2014). CSA is an approach that can greatly help smallholder farmers to adapt to climate change and its effects as it embraces multiple objectives: firstly, increasing agricultural productivity to support increased incomes, food security and development; secondly, increasing adaptive capacity at multiple levels (from farm to nation); and thirdly, decreasing greenhouse gas emissions and increasing carbon sinks (FANRPAN, 2012; Campbell et al., 2014). Thus, CSA strengthens the resilience of ecosystems and livelihoods to the effects of climate change (Neufeldt et al., 2013). Thus, all cases of CSA invariably turn out to be cases of SI. In this regard, Sustainable Land Management (SLM) practices, including soil and water conservation measures that meet CSA requirements are key contributions to achieving sustainable intensification and land degradation neutrality through resilience at local, regional and national levels.

\subsection{Causes of water erosion and consequences for drylands}

Soil erosion is the major physical agent of soil degradation in drylands (World Soil Report, 2015), while factors such as rainfall, topography, lack of vegetation cover, soil properties, and land use practices are the immediate causes of the related soil loss (Morgan, 1986; Hallsworth, 1987). Soil erosion is the movement and transport of soil by various agents, particularly water, wind, and mass movement, that leads to a loss of soil (WMO, 2005); and it is one of the most serious environmental problems facing human society. Each year about 10 million ha of cropland worldwide are lost due to soil erosion, thus reducing the cropland available for food production. Overall, soil is being lost from land areas 10 to 40 times faster than the rate of soil renewal, endangering future food security and environmental quality (WMO, 2005). 
As humans obtain more than $98 \%$ of their food calories from the land (Pimentel, 2006), maintaining and augmenting the world food supply depends on the productivity and quality of all soils. Accelerated water erosion degrades agricultural soils through the loss of organic matter, diminished nutrient supply and impaired hydrologic function, thus, diminishing soil quality and, thereby the productivity of the agricultural systems (Pimentel, 2001; Bossio et al., 2010). Finding ways to reduce or control soil erosion is therefore of vital importance.

The extremes of variable rainfall, one of the effects of climate change, can enlarge land degradation problems, as too much rain causes water erosion through runoff while the lack of, or too little, rain causes degradation through lack of vegetation cover. Rainfall can erode soil by the force of raindrops, surface and subsurface runoff, and river flooding (WMO, 2005). Rainfall intensity is the most important factor governing soil erosion caused by rain. In general, the higher the intensity of the rainfall the greater the soil particles that are carried away.

Raindrops play a crucial role in detaching soil particles. They remove a thin film of the soil from the land surface, originating sheet erosion, the dominant form of soil degradation from erosion (Oldeman, 1997). Once dislodged, the soil particles become susceptible to being carried away with runoff. A critical factor that determines soil erosion by rainfall is the permeability of the soil, which indirectly influences the total amount of soil loss and the pattern of erosion on slopes (WMO, 2005).
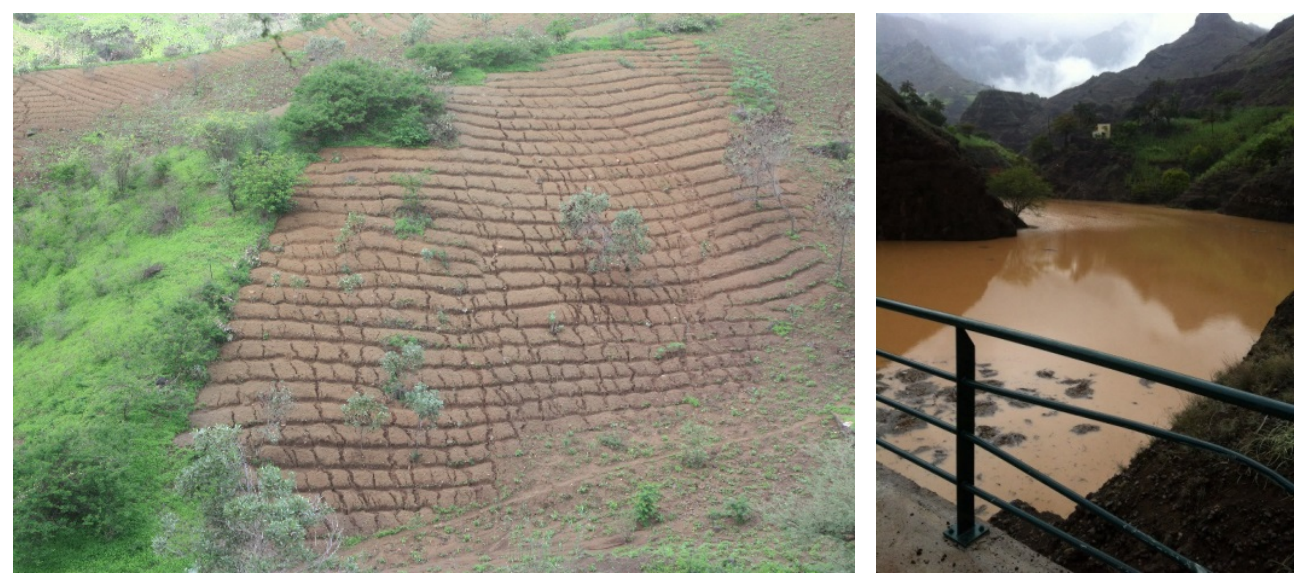

Figure 1.1 On-site impact of erosion: severe riling on a hillslope used for peanut cultivation on Santiago Island (left), and siltation of rainwater collecting dam (right) (note the sediment-rich water). 


\subsubsection{On-site and off-site effects of erosion}

Effects of soil erosion can occur on-site or off-site, further away from the source of erosion. The main on-site impacts are the reduction in soil quality, which results from the loss of the nutrient-rich upper layers of the soil, and the reduced water holding capacity of the eroded soils. Loss of soil quality is a long-term problem; globally, soil erosion's most serious impact may be its threat to the long-term sustainability of agricultural productivity (Poesen et al., 2003).

The decreased agricultural yields are common in the developing countries of Africa and Asia (Pimentel, 2006), but it causes concern also in the developed world. In erosion-prone areas of the more developed countries, however, productivity may be maintained in the short to medium term by increased fertiliser input, making the effects of erosion rarely acknowledged by farmers. This strategy is however infeasible with regard to erosion in developing countries.

In addition to on-site effects, eroded soil may be transported considerable distances, giving rise to off-site problems. Water erosion's main off-site effect is the movement of sediment into watercourses, which can lead to the silting-up of dams (Figure 1.1), disruption of the ecosystems of lakes and wetlands, and contamination of drinking water. In some cases, increased runoff may also occur due to the reduced capacity of eroded soils upstream to absorb water, leading to downstream flooding and local damage to property (Poesen et al., 2003).

Another major off-site impact may result from the agricultural chemicals that often move with eroded sediment. These chemicals pollute downstream watercourses and water bodies (Geissen et al., 2007). In the rich nations, where inputs of agricultural chemicals are high, costs of removing such pollutants from drinking water can be considerable. On the other hand, in poor nations, cost of chemical inputs are often prohibitively expensive, hence there is more focus on improved resource use efficiency to attain sustainable intensification.

On sloped lands, the impact of soil erosion is intensified because most of the soil particles dislodged by raindrops are carried away as the water flows downhill into the valleys and waterways. Since on steep slopes soils are generally shallower, with limited water and nutrient storage capacity, they are very vulnerable to degradation when exposed to eroding agents (Pimentel et al., 1998). 
Soil loss directly affects dryland crop productivity through loss of productive top soil, decreased water availability due to deteriorated physical properties of soil and loss of essential nutrients. This loss of crop productivity decreases the efficiency of rain as less crop is produced per amount of rain, or "less crop per drop" as pointed out by Stroosnijder (2009). Dryland precipitation is inherently variable in amounts and intensities and so are the subsequent runoff and erosion. Different forms of soil erosion such as gullies, rills, mass flow, and sheet erosion can occur depending on the topographic landform. Nonetheless, this research focuses on sheet erosion since it is the main form of soil erosion on the dryland hillsides in Cabo Verde.

\subsubsection{Causes and consequences of loss of plant available water by runoff}

Runoff occurs when rain intensity exceeds the infiltration capacity of the soil. Infiltration capacity measures the ability of the soil to absorb and transmit water (Lal, 1975; Le Bissonnais et al., 2005). Runoff occurs more commonly in arid and semiarid regions, where rain intensities (and/or erosivity) are high and surface crusting, dryness or rock fragments impede soil infiltration (Cerdà, 1996, 2001). The generation of runoff is an important factor in soil loss (Le Bissonnais et al., 2005) and has a strong relationship with the incidence of erosion. Shallow soils, which are common in Cabo Verde drylands, are highly susceptible to overland flow when saturated (Smolikowsky et al., 2001).

Water erosion induced land degradation affects soil quality and productivity at the field scale and affects water availability, quality and storage (Gao et al., 2014), by reducing infiltration rates, soil depth, water holding capacity, nutrients, organic matter, and soil biota. Runoff decreases water availability to crops, which results in less crop yield, thus, decreasing RWUE, which is already remarkably low in sub-Saharan Africa, where plants use only about $15 \%$ of the rainwater for the production of food, fibre and fodder (Stroosnijder, 2009).

\subsubsection{Nutrient and organic matter (OM) loss related to erosion and runoff}

Soil erosion leads to the loss of essential plant nutrients and organic matter (OM) from top soil, a process that also occurs in soils with a high leaching potential and a low buffering capacity (IPCC, 2007). Nutrient depletion can in turn also be a contributing cause of soil erosion because, in cases where nutrients are limiting, there is lower production of aboveand below-ground biomass, which protects the soil against erosion. This feedback is less frequently recognized than the fact that erosion causes nutrient depletion. The quantity of 
nutrient and OM loss by soil erosion is the product of soil loss and the nutrient content of sediment, but may also be predicted from soil loss and topsoil nutrient content. Nutrient depletion as a form of land degradation has a severe economic impact at the global scale, especially in sub-Saharan Africa where replenishment of soil nutrients through organic and inorganic fertilizers constitutes a great constraint (Adimassu et al., 2014).

Nutrient balance studies, where the effect of added nutrients on soil loss can be quantified, help to identify those situations where nutrient depletion is a cause of soil erosion (Zougmoré et al., 2009). In semiarid drylands, the low availability of animal manure and crop residue has reduced the amount of organic matter, which should have been added into soils as organic fertilizers (Zougmoré et al., 2010). Because of the low soil $\mathrm{OM}$, the soil structure has deteriorated and soils have become fragile and prone to erosion (Tan et al., 2005). In nutrient balances for low-input systems, nutrient losses by soil erosion can be very large and such balances highlight which interventions should receive priority.

Runoff and water erosion can transport nutrients and OM from the field either dissolved in solution or associated with soil particles, reducing the amount of nutrients available to support crop production (Pimentel et al., 1995; Roose, 2004; Dass et al., 2011). Nutrient deficiency can lead to low crop yields due to poor crop development, making the use of available water inefficient. As nutrients and moisture are the primary factors limiting crop growth and productivity in sub-Saharan Africa (Bationo et al., 2007; Bossio et al., 2010), addressing nutrient deficiency is essential to maximise the efficiency of rainwater use.

Nitrogen is mostly lost in runoff while phosphorus is mostly lost adsorbed to the eroded soil (Ali et al., 2007; Zougmoré et al., 2009; Xia et al., 2013; Baptista et al., 2015c). The use of organic amendments such as compost, animal or green manure can significantly reduce nutrient losses since their incorporation into the soil can improve aggregate stability and thus reduce $\mathrm{NO}_{3}-\mathrm{N}$ and $\mathrm{PO}_{4}-\mathrm{P}$ losses. Likewise, mulch can protect soil against the impact of raindrops, decrease runoff velocity and improve the infiltration capacity of the soil, thus further helping to control erosion and nutrient loss (Zougmoré et al., 2003; Novara et al. 2013).

Although loss of nutrients and OM due to erosion is significant, research has shown that it is largely reversible using inorganic and organic fertilizers (Zougmoré et al., 2010; Wu et al., 2015). Yet subsistence farmers in countries with low-input agriculture are not able to replace the lost nutrients with expensive fertilizers (Altieri \& Toledo 2005), and, in hilly dryland areas, there are also environmental risks associated with fertilizer application. The rate of restoration of the soil OM pool is extremely slow, while that of its depletion is often very rapid (Lal, 2009). OM in soils improves soil structure, root penetration, water- 
holding capacity and infiltration. With increasing OM, soil erodibility decreases (Wischmeier \& Smith, 1978).

Several studies have evaluated soil erosion under techniques that reduce runoff and erosion (Smolikowski et al., 2001; Ali et al., 2007; Tavares, 2010; Tavares et al., 2013; Xia et al., 2013; Novara et al., 2013). However, less attention has been given to the quantification of the effects of these measures on nutrient losses associated with runoff and erosion, and the impact of these measures on soil nutrient balances and crop productivity, particularly on hilly dryland areas.

\subsection{Sustainable land management strategies in drylands: erosion and runoff prevention}

Sustainable land management (SLM) is the key to assuring long-term productivity of inhabited drylands through mitigation/prevention of land degradation and desertification. SLM is a form of land management that is targeted toward improving or stabilising agricultural productivity, improving people's livelihood and improving ecosystems (Schwilch et al., 2012a). SLM is the use of land resources, including soils, water, animals and plants, for the production of goods to meet changing human needs, while simultaneously ensuring the long-term production potential of these resources and the maintenance of their environmental functions (WOCAT, 2007). Thus, SLM strategies that remediate important soil functions can restore the productivity of degraded soils (Gruver, 2013). Soil fertility restoration which benefits both soil structure and hydrologic function is one important SLM strategy.

Restoration of soil hydrologic function that has been lost due to erosion, though a serious challenge is possible through practices that raise OM levels, especially at the soil surface. For example, SLM farming practices that minimize tillage, maximize soil cover, and utilize additional organic inputs (i.e. animal or green manure and compost) have been known to restore the productivity of soils degraded by water erosion (Gruver, 2013). Higher OM levels in the top layer of an eroded soil can dramatically increase water infiltration and infiltration, nutrient cycling and resistance to detachment (Franzluebbers 2002).

A wide range of reliable and proven SLM techniques are also available to mitigate land degradation and increase dryland crop yield through improving rainwater-use efficiency and decreasing runoff in dryland farming systems (Erenstein, 2003; Rockstrom et al., 2002, 2009; Stroosnijder, 2003, 2009; Turner, 2004; WOCAT, 2007). In dryland regions, 
water-management techniques such as water-harvesting (WH) are very promising forms of SLM (WOCAT 2007). They can consist of: (a) mechanical structures (i.e. terraces, check dams, contour stone walls, contour ridges, etc.) applied at field and micro watershed scales; (b) biological structures (i.e. vegetation strips, afforestation) applied at field and micro watershed scales; (c) soil surface manipulation (i.e. tillage, mulching/residue management, soil amendments) applied at field scale); (d) rain water harvesting (i.e. reservoirs, retaining dams, etc.) at flood, micro and field scale.); and (e) agronomic measures (i.e. drought resistant species and varieties, short cycle varieties, crop rotation, green manures, appropriate fertilizer use, compost, weed control, etc.) applied at field scale. These soil-water conservation and $\mathrm{WH}$ practices decrease erosion (less runoff), increase infiltration (less surface evaporation), reduce runoff and increase green wateruse efficiency, i.e. the fraction of rainwater that is used for biomass production (Stroosnijder, 2003). While each technique may be used individually or in combination with other erosion control techniques, the implementation of the appropriate techniques has the potential to reduce runoff, erosion and nutrient loss 2 to 1000 -fold and water loss from 1.3 to 21.7-fold (Pimentel et al., 1995).

Covering the soil with crop residues also helps to reduce runoff (Araya et al, 2011; Baptista et al, 2015b). On bare fields, the rate of soil loss by water is many times magnified, presenting a threat to agricultural fields both in wet and dry areas. Residue mulch offers a high degree of soil cover, which limits runoff by providing a physical barrier and protecting the soil surface from the erosive energy of rainfall (Baptista et al., 2015b). SLM techniques that cover the soil (i.e. residue mulch), increase infiltration, while reducing runoff and splash effect, thus limiting the transport of detached particles. On the other hand, practices that slow down runoff, such as terraces and vegetation hedges, promote deposition of suspended sediment before it leaves the field. The positive effect of soil cover on both runoff and soil loss indicates the importance of maintaining some residue on the soil surface during erosive rainfall events (Cerdà, 2001; Hartanto et al., 2003; Kairis et al., 2013). Organic amendments including crop residue cover and organic fertilizers (i.e. animal and green manures), also have the potential to simultaneously improve water conservation and soil fertility, promoting water-nutrient synergy (Bossio et al, 2010; Stroosnijder et al., 2012).

Some of these measures may succeed under certain combinations of conditions but may fail in other settings. Farmers' perception of the benefits of the measures is also an important factor to consider. Moreover, it is advisable to test the measures in each specific condition and offer farmers a selection of integrated management options that would give sufficient benefits against reasonable costs. Sufficient studies and reviews demonstrate that land degradation affects all facets of life (Barrow, 1991; Blaikie and 
Brookfield, 1987; Johnson and Lewis, 1995). A large number of SLM techniques is described to mitigate land degradation and restore land productive capacity (Erenstein, 2003; Stroosnijder, 2003, 2009; Turner, 2004; WOCAT, 2007; Rockstrom et al., 2009). However, there are few studies on the biophysical as well the socioeconomic impact of implemented SLM techniques (Abdi et al., 2013; Tavares et al., 2013; Zougmoré et al., 2014), particularly in semiarid hilly, drylands conditions (Baptista et al., 2015a).

The selection of appropriate SLM techniques should involve active participation of farmers to increase the chance of adoption and success in developing solutions, leveraging their knowledge and experiences and combining them with technical knowledge (Reed et al., 2005; Schwilch et al., 2012; Mutekenga et al., 2013; Tavares et al., 2013). The selection should take into account the biophysical characteristics of the area where the techniques will be applied, the socioeconomic conditions of the farmers, the cost of the techniques and their applicability to the site (Baptista et al., 2015b). Moreover, for farmers to adopt adequate SLM practices, the practices must be attractive in economic terms, i.e. have potential from a farmer's perspective, lead to cost reductions, benefit enhancements, or both (Teshome et al., 2013; Fleskens et al., 2014). Hence, in short, to support sustainable intensification, SLM measures are required that reduce runoff, erosion and nutrient losses while boosting productivity.

This thesis project investigated SLM techniques (i.e. residue mulch, vegetation barriers, organic fertilizers), including rainwater harvesting (i.e. planting pits) at different scales and under different scenarios in the semiarid, hilly drylands of Cabo Verde. We looked at the effects of these measures not only on runoff and erosion, but also on soil nutrient balances and crop productivity, taking into account both their biophysical as well the socioeconomic impacts.

\subsection{Aim and research questions}

The main objective of this thesis is to explore SLM techniques for sustainable intensification of Cabo Verde drylands. The focus is on optimizing soil and water management by reducing runoff and soil and nutrient losses and increasing crop yield. The research combines traditional and scientific knowledge in a field-based participatory process with local stakeholders.

This research addresses the following research questions:

I. What have been the impacts of implemented soil and water conservation strategies on livelihoods in Cabo Verde drylands in the last decades? 
II. What are the most important criteria for farmers in selection of land management practices/techniques?

III. How do selected land management techniques influence runoff and soil erosion?

IV. How do selected land management techniques influence erosion and runoff related nutrient losses and crop productivity?

V. What is the potential of promising SLM technologies at Santiago Island under variable climate scenarios?

This thesis presents options to support moving from a state of land degradation towards more sustainable land management in semi-arid hilly drylands through implementation of SLM techniques and approaches that reduce runoff and soil loss, increase water infiltration, soil nutrients and crop productivity, and ultimately contribute to sustainable intensification, adaptation to climate change, land degradation neutrality and food security in Cabo Verde.

\subsection{Methodological approach}

\subsubsection{The study area}

The Cabo Verde Islands are located in the central eastern Atlantic $\left(14^{\circ} 50^{\prime}-17^{\circ} 20^{\prime} \mathrm{N}\right.$, $22^{\circ} 40^{\prime}-25^{\circ} 30^{\prime} \mathrm{W}$ ), ca. $500 \mathrm{~km}$ West of Senegal. There are 10 islands (of which nine are inhabited by about half a million people) and 8 Islets, totalling a land area of $4033 \mathrm{~km}^{2}$. Severe land degradation occurs in the whole country, in different ways and extent according to the physical characteristics of the islands. To prevent land degradation and to enable agriculture production, both structural and biological SWC and water harvesting measures have been implemented at watershed, island and country level scale in the last decades (see chapter 2 ).

Santiago is the largest island, both in size $\left(991 \mathrm{~km}^{2}\right)$ and population $(250,000)$. It is the most important agricultural centre and home to the nation's capital city of Praia. The island is mountainous, although slightly flatter in the southeast. The climate is predominately semiarid, though arid and sub humid in parts, with two seasons: a moderate season (December-June, with an average seawater temperature of $22^{\circ}-23^{\circ} \mathrm{C}$ ) and a warm season $\left(26^{\circ}-27^{\circ} \mathrm{C}\right)$. Precipitation is meagre and erratic as the country can be seen as an island extension of the arid Sahel zone.

Rainfall, the dominant climate factor influencing land degradation, is extremely variable in both space and time, and strongly influenced by elevation and topography. This is the 
result of the seasonal migration of the Inter-Tropical Convergence Zone (ITCZ) around the equator, which generates a single, short wet season from July to October, coinciding with high temperatures, and a long dry season from November to June (Langworthy \& Finan, 1997; Sanchez-Moreno et al., 2013). Rainfall is extremely heterogeneous and its spatialtemporal distribution irregular, typically ranging from 200 to more than $650 \mathrm{~mm}$ in the upwind façade to less than $100 \mathrm{~mm}$ in the downwind side.

Of the arable surface on Santiago, $>90 \%$ is used for rain-fed agriculture, particularly the staple crops (maize and beans) and about 5\% is used for irrigated crops (sugarcane, fruits, vegetables, cassava and sweet potato). Livestock keeping is an important activity in the rural areas. About $30 \%$ of the island's surface is forested.

The soils are mainly of volcanic origin, developed on basaltic substrate, are shallow and low in organic matter (OM), generally with low to medium fertility and medium to coarse texture. Most soils, particularly on the steep slopes, exhibit marked symptoms of degradation (i.e. rills, gullies and sheet erosion). Deeper soils, with higher OM content can be found on the plateaus of less steep slopes. In the valley bottoms or ribeiras, Fluvisols are predominant and used for irrigated agriculture.

The Ribeira Seca Watershed (Figure 1.2) was selected as the experimental area because it is the largest $\left(72-\mathrm{km}^{2}\right)$ watershed of Santiago and can be considered a reference area for the number and diversity of soil conservation measures implemented in recent decades. At the same time, it still exhibits high rates of land degradation due to drought, erosion by water and inappropriate agricultural practices. Detailed climatic and physiographic characteristics of the RSW, which are similar to those of most watersheds in the island and the country, can be found in the different core chapters of this thesis.

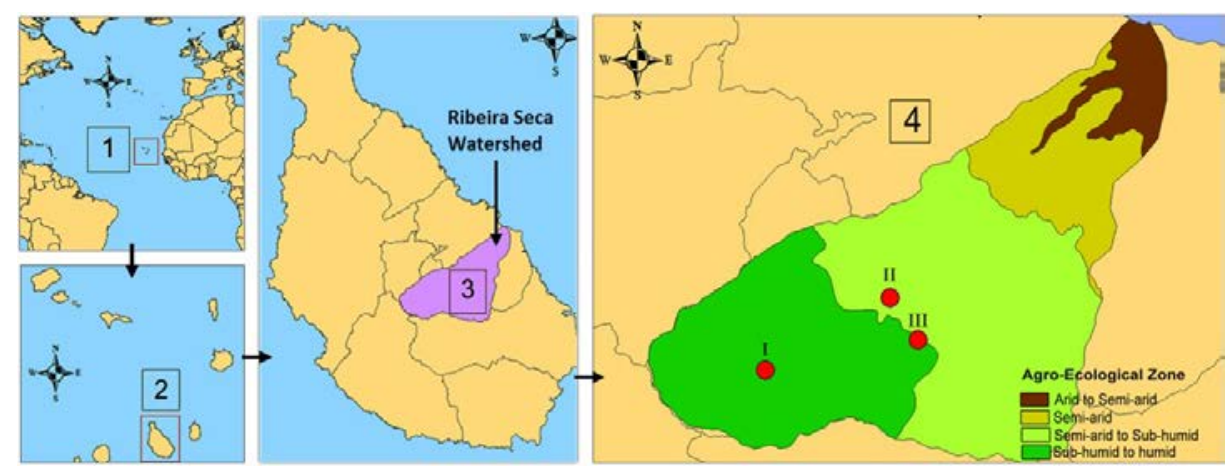

Figure 1.2 Location of the experimental sites. (1) The Cabo Verde Islands in relation to Africa, (2) the island of Santiago within the Cabo Verde Islands, (3) the Ribeira Seca Watershed (RSW) on Santiago, (4) the experimental sites within the RSW. 


\subsubsection{Methods}

The methodology used in this research comprised a combination of biophysical and socioeconomic field surveys, a comprehensive literature review of global practices, a stakeholder workshop, multi-location field trials to assess innovative SLM practices, statistical data analyses of field trial results, and biophysical and economical modelling to assess benefits of the promising techniques at larger scale, as depicted in figure 1.3.

The tested land management techniques were assessed and selected using a simplified version of the participatory approach developed by Schwilch et al. (2009) and applied by Tavares et al. (2013), which combines collective learning and decision-making with the application of evaluated global best practices. A list of techniques with the potential to increase the efficiency of rainwater within the study site was selected, mainly from the WOCAT database (WOCAT, 2007), and presented to local farmers in a stakeholder workshop before the start of the field experiments. The farmers identified and prioritized constraints to dryland production and proposed solutions for each priority. Based on the farmers' preferences, the selected technologies were combined into three treatments (T1T3) which were compared to an untreated control (TO). The treatments varied among the sites, and each consisted of a combination of an organic amendment (compost, animal manure or green manure) with a water-management technique (residue mulch, soil surfactant and/or pigeon pea (Cajanus cajan) hedges.

Three collaborative field trials, two on-farm and one on-research station, were conducted in different agro-ecological zones during two rainy seasons to test the effect of the different SLM techniques on runoff, soil erosion, nutrient losses and crop productivity.

The crops used in the experiments were maize (Zea mays) and two local types of beans (Vigna unguiculata, and Lablab purpureus).

Data collection comprised runoff and eroded soil after each erosive rainfall event for quantification and laboratory analysis, rainfall amount and intensity, soil moisture, infiltration, maize and bean yield and crop biomass. All statistical analyses were performed using SPSS 19.0.

At the end of the experiments, local farmers participated in the evaluation of the tested treatments and the determination of which were the best options according to their preferences. The PESERA-DESMICE (Fleskens et al., 2014) approach was used to model the biophysical and economic impact of the promising treatments compared to traditional practices, under variable climate conditions and to assess their applicability at island scale. 
Details of the field experimental methodology, data collection procedures and analyses can be found in the individual empirical chapters.

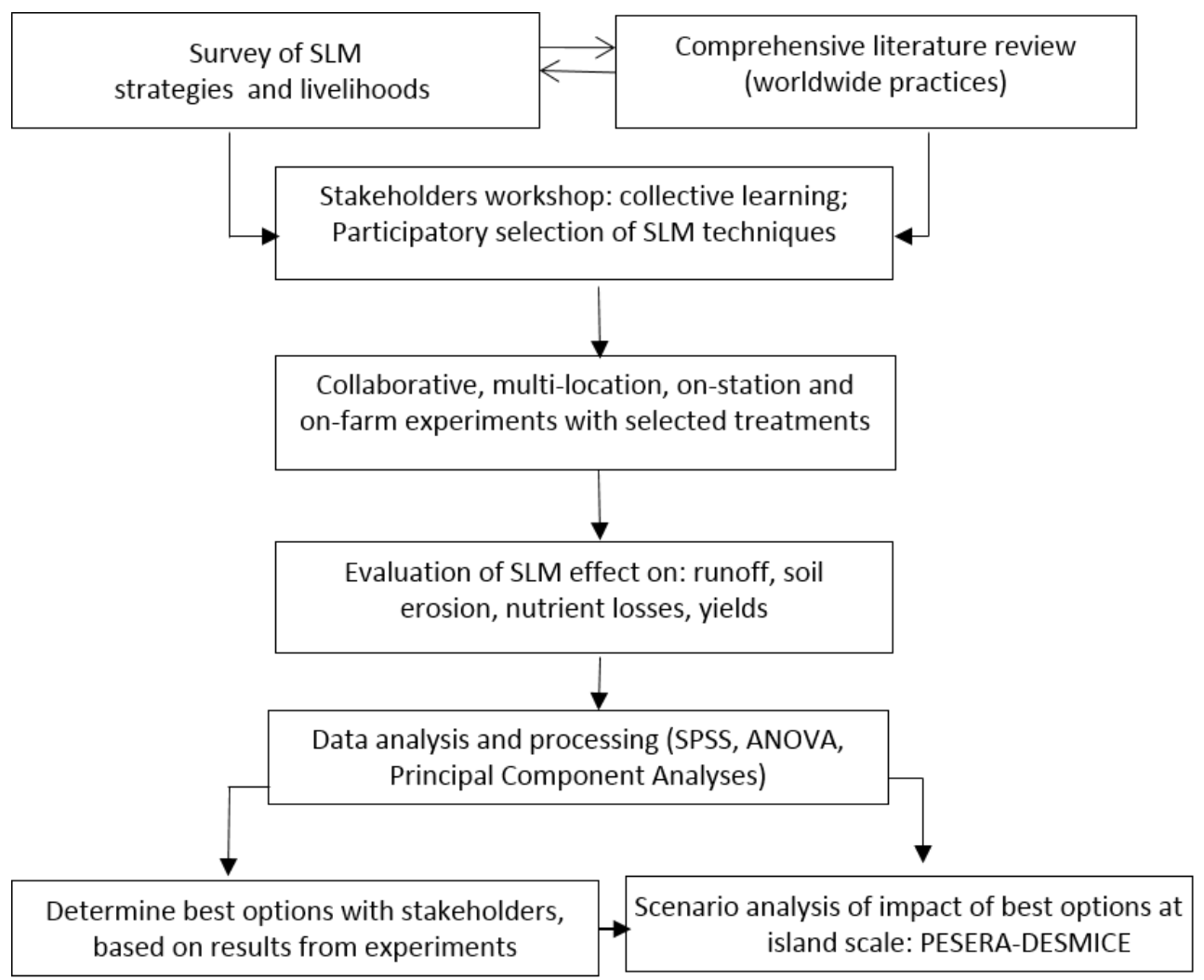

Figure 1.3 Schematic representation of the methodological approach

\subsection{Thesis outline}

The research questions are addressed in the following four chapters (2 to 5) and subsequently linked together by the Synthesis in chapter 6 . Since all the chapters have either been published in, or submitted to, international peer reviewed journals; they are all stand-alone articles that can be read independently. Figure 1.4 summarizes the outline of this thesis, indicating the research topic(s) addressed in each chapter.

Chapter 2 reviews the sustainable strategies towards building resilience against the harsh environmental conditions in Cabo Verde, analyses the state of land degradation and its 
drivers, surveys the existing Soil and Water Conservation (SWC or SLM) measures, and assesses their effectiveness against land degradation and people's livelihood in response to research question 1 . This chapter provides a panoramic view of the importance of SLM measures for the Cabo Verde drylands and recommends further specific, scientifically based assessment of the biophysical and socioeconomic impact of SLM and potential upscaling.

Chapter 3 first discusses the participatory approach used in selecting the SLM techniques that are field-tested in this research, in response to the second research question. It then reports on the effects of the selected combined techniques on the generation of runoff and soil loss from rain-fed agricultural fields, in comparison with traditional farmers' practices. For this purpose, and to address the third research question, three collaborative field trials were conducted in different agro ecological zones during 2011 and 2012 rainy seasons. The chapter also discusses the main factors influencing runoff and soil loss in semiarid dryland hilly areas.

Chapter 4 complements chapter 3 by further evaluating the effects of the techniques tested on the field trials on erosion and runoff related nutrient losses and crop productivity in response to research question 4. Based on the results, this chapter identifies and recommends sustainable land management techniques to prevent nutrient depletion, improve dryland crop yield and avoid further land degradation due to erosion by water.

Chapter 5 follows up on the recommendations in chapter 2 for further scientifically based biophysical and socioeconomic evaluation of SLM techniques and their potential upscaling. This chapter draws its input from chapters 3 and 4 to address research question 5. With the results of chapters 3 and 4 demonstrating the potential of the best techniques, but also significant spatial-temporal yield variability, this chapter shows how the PESERADESMICE modelling approach can be used to capture a greater range of climatic conditions and evaluate the biophysical and social economic benefits of the selected conservation techniques against a traditional baseline condition. It also analyses the potential for upscaling the selected techniques.

Finally, chapter 6 is a synthesis of the research findings, highlighting the new contributions they make to the field of study of the impact of SLM on erosion, runoff and nutrient losses in semiarid hilly drylands. This chapter also links the results of the research to current scientific debates and international context policies on land degradation, agriculture productivity for sustainable intensification and climate smart agriculture. Additionally, this chapter provides directions for further research and concludes with policy 
recommendations for sustainable management of soil and water in hilly drylands to prevent further degradation and to contribute to a land degradation neutral world.

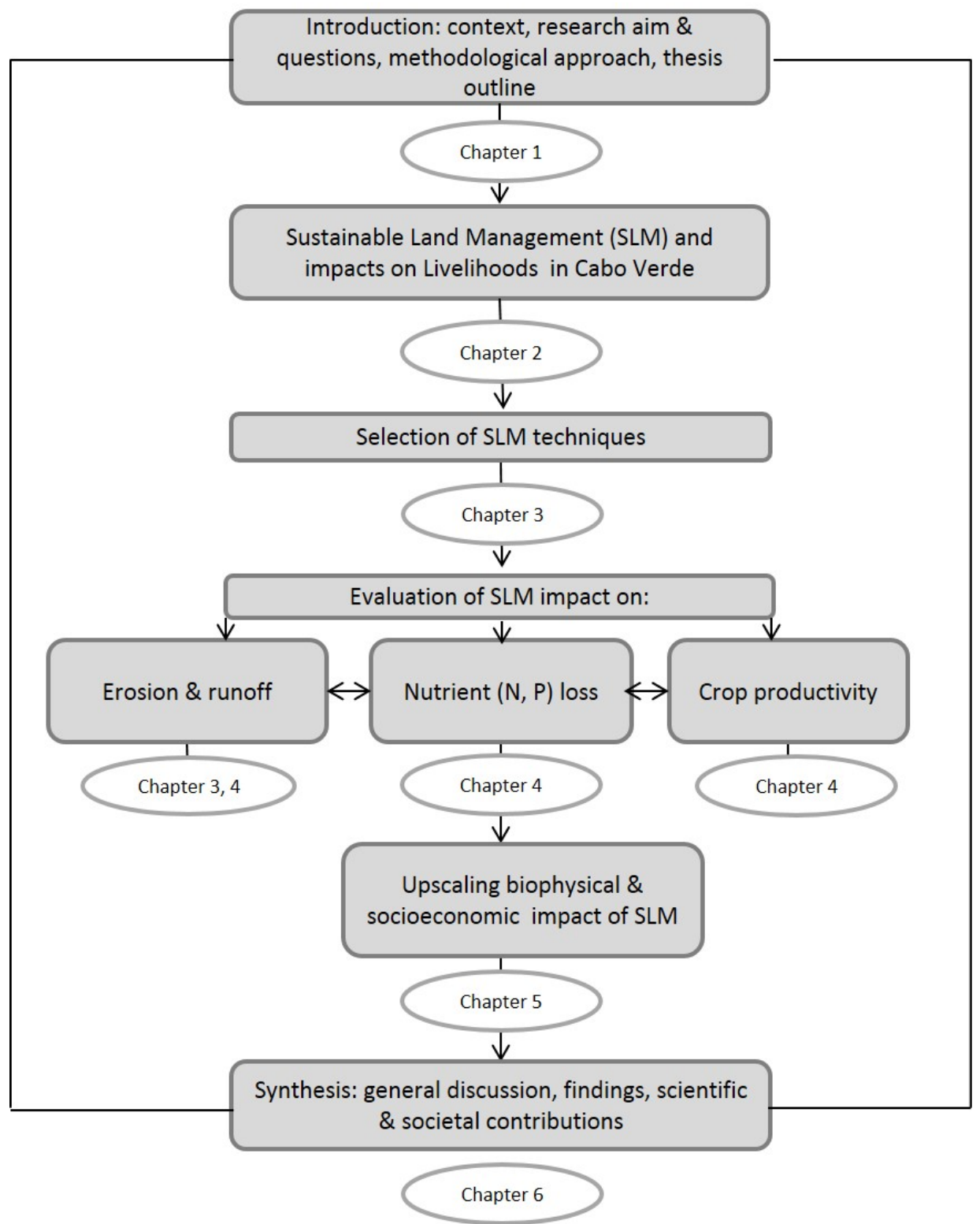

Figure 1.4 Thesis outline, indicating the chapters in which the different topics are addressed and the relation between them. 


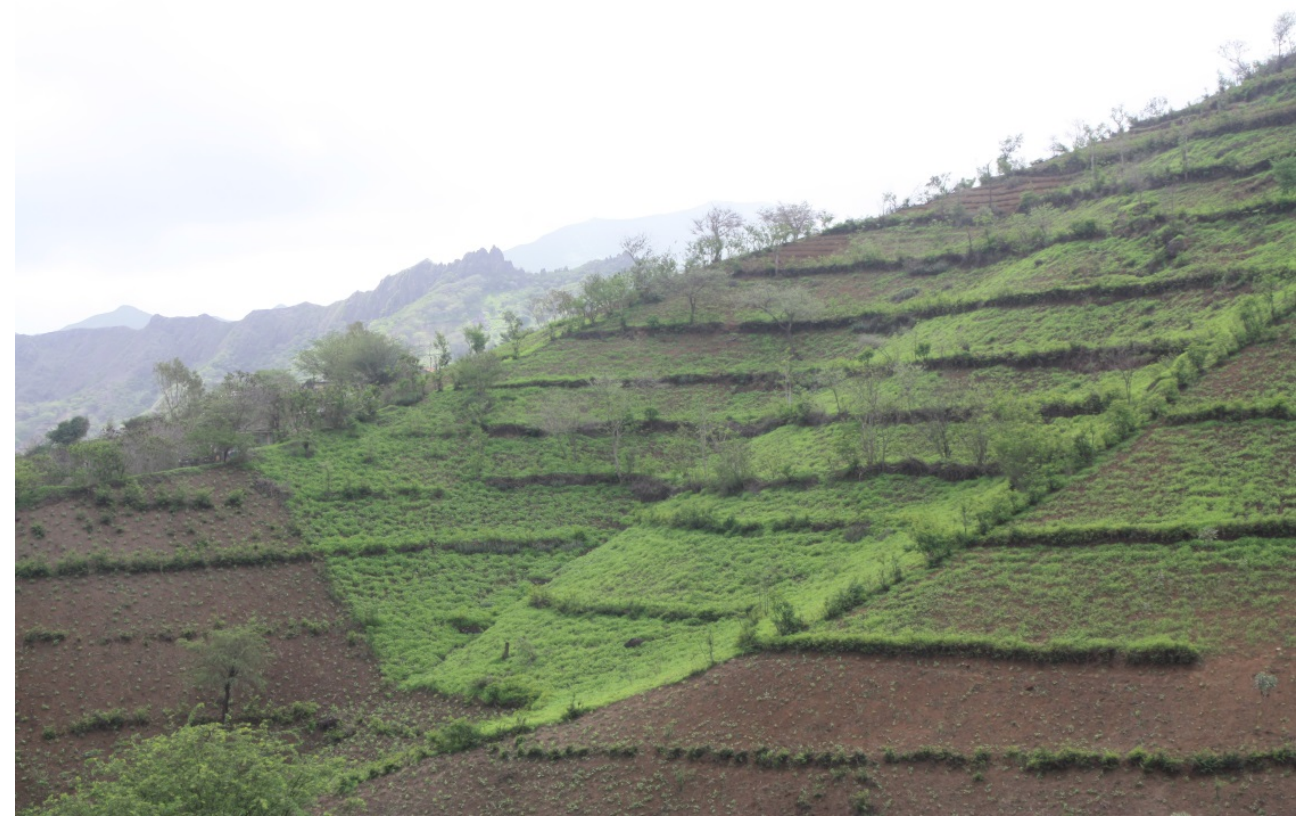




\section{Sustainable land management strategies in Cabo Verde and their impacts on livelihoods: an overview from the Ribeira Seca Watershed}

Severe land degradation has strongly affected both people's livelihood and the environment in Cabo Verde, a natural resource poor country. Despite the enormous investment in soil and water conservation measures (SWC or SLM), which are visible throughout the landscape, and the recognition of their benefits, their biophysical and socioeconomic impacts have been poorly assessed and scientifically documented. This study contributes to filling this gap, by bringing together insights from literature and policy review, field survey and participatory assessment in the Ribeira Seca Watershed through a concerted approach devised by the DESIRE project (the "Desire approach"). Specifically, it analyses government strategies towards building resilience against the harsh conditions, analyses the state of land degradation and its drivers, surveys and maps the existing SWC measures, and assesses their effectiveness against land degradation, on crop yield and people's livelihood. The inference is that the relative success of Cabo Verde in tackling desertification and rural poverty owes to an integrated governance strategy that comprises raising awareness, institutional framework development, financial resource allocation, capacity building, and active participation of rural communities. The study recommends that specific, scientific-based monitoring and assessment studies be carried out on the biophysical and socioeconomic impact of SLM and that the "Desire approach" be scaled-up to other watersheds in the country.

This chapter is published as:

Baptista, I., Fleskens, L., Ritsema, C., Querido, A., Tavares, J., Ferreira, A.D., Reis, E.A., Gomes, S., Varela, A. 2015. Soil and water conservation strategies in Cape Verde (Cabo Verde in Portuguese) and their Impacts on livelihoods: an overview from the Ribeira Seca Watershed. Land 4: 22-44. 


\subsection{Introduction}

Cabo Verde is a small island country where a mix of climatic, geomorphologic, pedologic and human factors has resulted in widespread land degradation, with negative consequences for the livelihood of the population and its fragile environment (Smolikowski et al., 2001; Ferreira et al., 2013). The scarcity of natural resources and the weakness of the productive system make poverty a structural occurrence in the country.

Desertification, associated with the occurrence of extreme drought episodes, has been present throughout the country's history and has led to periods of food production deficit and famine, which in the past have caused thousands of deaths (Ferreira et al., 2013). Following the last big famine in the late 1940's, the authorities took measures to eradicate famines from the country. The stabilization of the agricultural landscape with erosion control measures and the maintenance of sustainable yields became absolute priorities, not just for environmental protection, but also for survival. Since the country's independence in 1975, successive governments have focused their rural development policies on soil and water conservation (SWC) strategies to address desertification, water scarcity, and soil erosion, aiming to reconstruct the ecological potential and reduce poverty in rural areas (DGA, 2004). This effort has completely changed the landscape to a level where SWC techniques can be found everywhere, with the exception of rock outcrops. This arduous task was performed in the interval of two generations, since the last big famine in 1948, and more assertively in 1975, using a set of SWC techniques (Ferreira et al., 2013) and a governance strategy involving the communities affected by the drought.

Several types of SWC measures were implemented throughout the country (i.e., terraces, half-moons, live barriers, contour rock walls, contour furrows, micro-catchments, check dams, runoff water collecting dams, water reservoirs, wells and afforestation with drought resistant species), aiming to hold the soil in place, the water in the soil and to combat desertification (Ferreira et al., 2013).

Current efforts to reverse and prevent land degradation focus on the concept of sustainable land management (SLM) which refers to the use of land resources to meet present needs without compromising the ability of future generations to meet their own needs (WOCAT, 2007; Cowie et al., 2011). SLM technologies include agronomic, vegetative, structural, and management measures to control land degradation and enhance productivity in the field (Schwilch et al., 2009); thus, SWC measures implemented in Cabo Verde promote the SLM concept. The increased efforts and financial resources allocated to the promotion of SLM calls for adequate monitoring and assessment (M\&A) 
of their impact and benefits. Nevertheless, SLM must reflect the human-environment interactions. This requires a system to systematically assess the impacts and benefits from SLM measures that remain a fundamental gap (UNU-INWEH, 2011).

Investments in SLM measures are enormous at the national level have been huge, yet a clear overview of their extent and combined benefits in terms of agriculture productivity, conservation effectiveness, sustainability, and rural people's well-being, is still lacking. Information on past interventions is scattered and of little influence for new SLM activities. Implementation of the five-year research project, DESIRE (Desertification Mitigation and Remediation of Land: A global approach for local solutions), contributed to fill part of the gap for the Ribeira Seca Watershed (RSW), giving policy makers and implementing institutions a spatial overview of past and ongoing processes, so that they can plan future activities. The DESIRE project developed an approach for establishing SLM strategies in response to desertification, consisting of five steps: (1) establishing land degradation and SLM context and sustainability goals with stakeholders; (2) identifying, evaluating and selecting SLM strategies with stakeholders; (3) trialling and monitoring SLM strategies; (4) up-scaling SLM strategies; and (5) disseminating the knowledge gathered (Schwilch et al., 2012).

Even though consistent biophysical impact and cost-benefit studies of SWC measures are lacking, their contribution to the improvement of environmental conditions of the treated landscape is visible (Moreno and Pereira, 2005), making crop production possible, and consequently improving the livelihood of the rural people (Ferreira et al., 2013). The implementation of SWC measures, particularly afforestation, has contributed to change the "lunar" aspect of the landscape to more pleasant and greener ones (Tavares et al., 2013).

Since most of the rain-fed cropland is on steep slopes, the main concern has been to protect the hillsides from runoff and erosion caused by heavy rain events, while neglecting in-field agronomic measures that lead to sustainable productivity increase, such as soil cover and nutrient management. Rain-fed crop yields remain low, with maize grain yield not exceeding one ton ha $^{-1}$. The low input farming system, dominated by continuous maize and beans intercropping still faces severe climate conditions, inadequate crop and land management practices, and land degradation.

This study aimed to corroborate the importance of SLM measures for Cabo Verde, the strategies undertaken to address desertification, and the impact of those measures on the environment and rural livelihood. More specifically, the study analysed the government strategies towards building resistance against the harsh conditions and, based on the 
DESIRE approach and results within the RSW, it analysed the state of land degradation and its drivers, surveyed and map the existing SWC measures, and assessed their effectiveness against land degradation and impact on crop yield and livelihoods. It also explored the governance aspects behind the relative success of Cabo Verde in tackling desertification and rural poverty, to verify the replication potential in countries with similar adverse conditions.

\subsection{Methods}

\subsubsection{Study Area}

\subsubsection{Cabo Verde natural resource endowment}

Rainfall and climate: Rainfall, as the dominant climate factor influencing land degradation, is extremely variable in both space, time, and strongly influenced by elevation and topography. It results from the seasonal migration of the Inter-Tropical Convergence Zone (ITCZ) around the equator, which originates a single short wet season from July to October, and a long dry season from November to June (Langworthy and Finan, 1997; Sanchez-Moreno, 2014). The climate is predominantly semi-arid. Rainfall typically ranges from 200 to over $650 \mathrm{~mm}$ in the upwind façade, to less than $100 \mathrm{~mm}$ in the downwind side.

Water resources: Cabo Verde has no permanent surface stock of fresh water, creating an almost total dependence on ground water supplies for domestic and agricultural use. Ground and superficial water resources are scarce as they depend on the erratic rainfall, susceptible to be lost to the sea. In an average rainfall year, about $20 \%\left(180\right.$ million $\left.\mathrm{m}^{3}\right)$ is lost through runoff; more than $50 \%$ is lost as evaporation; and only about $13 \%-17 \%$ recharges the aquifers (INGRH, 2010). About $60,000 \mathrm{~m}^{3} \cdot \mathrm{day}^{-1}$ are currently being pumped for irrigation, representing a serious overexploitation of available groundwater resources that contributes to soil and water salinization.

Soil resources and land management: Of the $4033 \mathrm{~km}^{2}$ of land surface that the country comprises, about $10 \%$ is cultivated. The soils are mainly of volcanic origin, medium to coarse textured, steep, low in organic matter and generally shallow. Of the arable surface $(41,000 \mathrm{ha}),>90 \%$ is used for rain-fed agriculture while about $5 \%$ is used for irrigated agriculture. About $23 \%$ of the country's surface is forested. Severe land degradation occurs in the whole country, in different ways and extent according to the physical characteristics of the islands. To prevent land degradation and to enable agriculture production, both structural and biological SWC and water harvesting measures have been 
implemented at a vast scale. For a more comprehensive review of the SWC and water harvesting measures, please refer to (Ferreira et al., 2013).

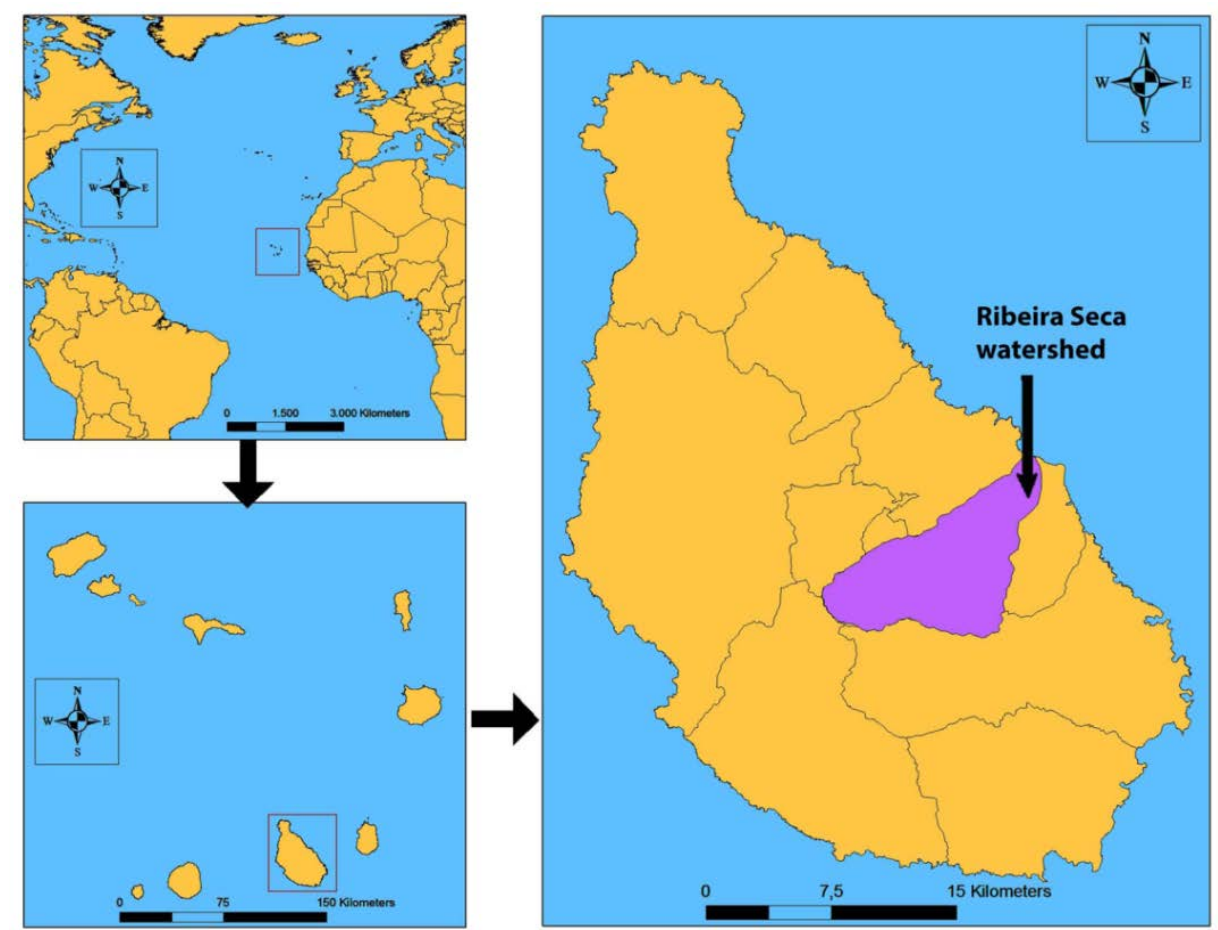

Figure 2.1 Location of the Ribeira Seca Watershed within Santiago Island and Cabo Verde.

\subsubsection{Ribeira Seca watershed: The Largest watershed in Santiago Island}

Ribeira Seca Watershed (RSW) is located on the east-central side of the Santiago Island, between latitude $15^{\circ} 07^{\prime} 40^{\prime \prime} \mathrm{W}$ and longitude $23^{\circ} 32^{\prime} 05^{\prime \prime} \mathrm{W}$ (Figure 2.1). With a drainage area of about $72 \mathrm{~km}^{2}$, it represents 4 agro-climatic zones: semi-arid (49\%), arid (20\%), subhumid (20\%), and humid (11\%) based on altitude, vegetation and relief (Diniz \& Matos, 1986).

The climate is characterized by a dry season that lasts 8-9 months (November to June) and a short, humid season of 3-4 months (July to October), with the humid period coinciding with high temperatures (Figure 2.2). Rainfall is extremely heterogeneous and its spatial-temporal distribution irregular. 


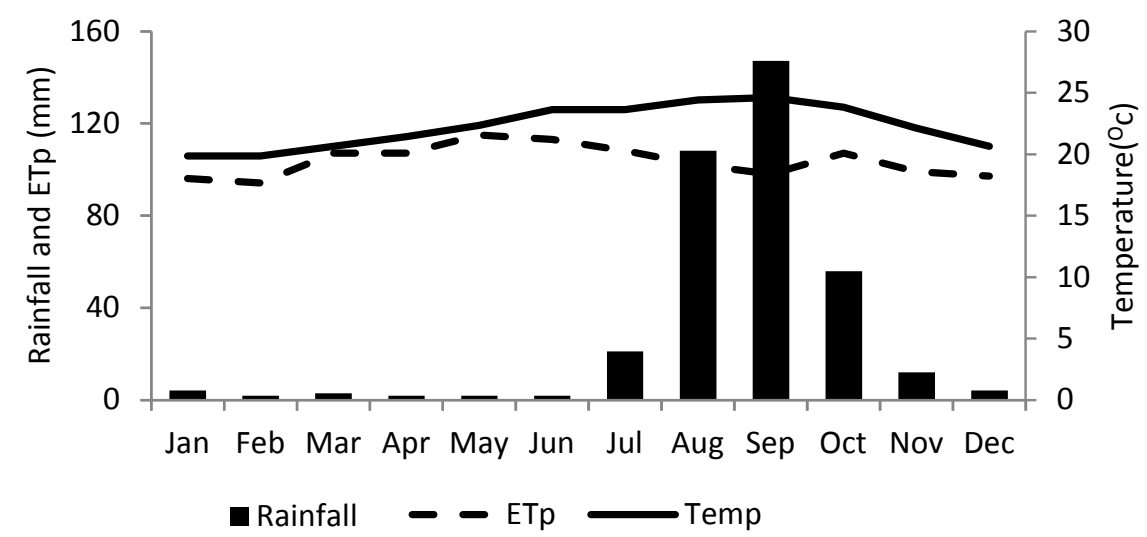

Figure 2.2 Mean annual rainfall distribution, evapo-transpiration and temperature for São Jorge Station (sub-humid zone of Ribeira Seca Watershed): period 1973-2010.

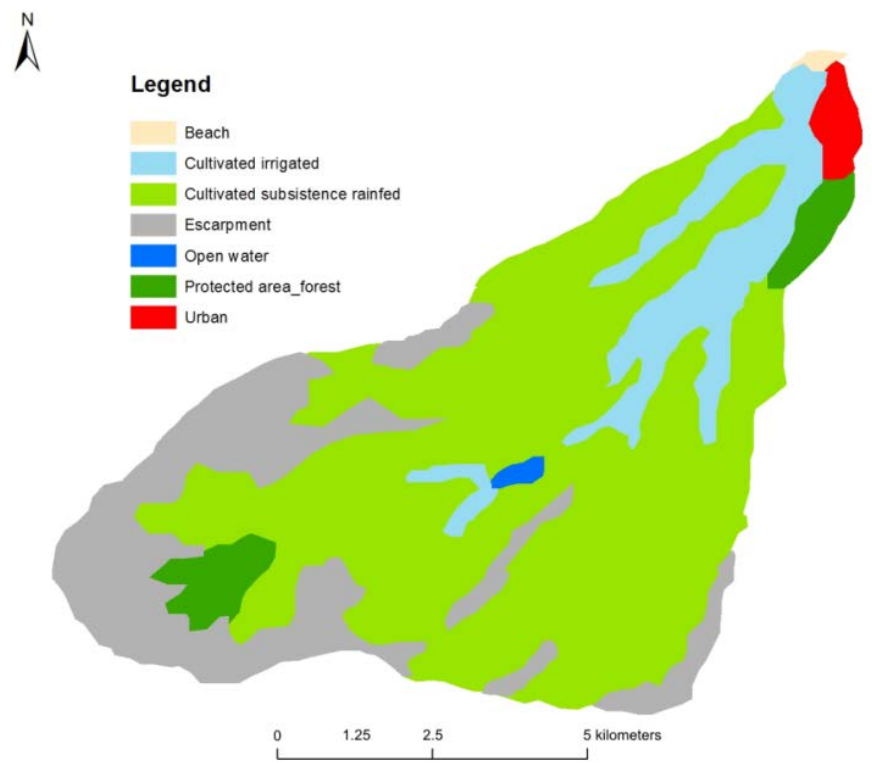

Figure 2.3 Map of land use types in the Ribeira Seca Watershed showing the dominance of rain-fed farming. Adapted from www.desire-his.eu.

The watershed has a maximum altitude of $1394 \mathrm{~m}$ and comprises seven sub-watersheds, characterized by steep slopes and annual precipitation that varies from $<200 \mathrm{~mm}$ downstream to $>650 \mathrm{~mm}$ upstream. The maximum average monthly temperature is 28.1 ${ }^{\circ} \mathrm{C}$ and the minimum is $16.6 \mathrm{C}$. The dominant land use is rain-fed agriculture (Figure 2.3), 
particularly the staple crops (maize and beans) and groundnut, occupying $83 \%$ of the area. The remaining area is used for: irrigated crops (sugarcane, fruits, vegetables, cassava and sweet potato) $5 \%$ (362 ha) and forest $4 \%$ (251 ha). In addition, 1\% are rock outcrops and 7\% are built environment (Figure 2.3). Livestock keeping is an important activity in the watershed as most family farmers own animals, such as cows, goats, pigs, and chickens that often graze freely.

The soils, developed on basaltic substrate, are mainly shallow and low in organic matter (OM), generally with low to medium fertility (INIDA, 1997) and medium to coarse texture, and exhibit marked symptoms of degradation (i.e., rills and gullies). Deeper soils with higher OM content can be found on the plateaus (achadas) of less steep slopes. In the valley bottoms or ribeiras, alluvial soils are predominant and used for irrigated agriculture.

The Ribeira Seca Watershed has an estimated total population of about 15,000 people, with an even gender distribution. Of the women, $43 \%$ are head of household. The population is young, with $77 \%$ below 35 years old (of which $48 \%$ are below 15) and features an $83 \%$ literacy rate (INIDA-DESIRE, 2008). Poverty (people living on $<\$ 1.25$ a day (World Bank, 2000) affects $>60 \%$ of the population. RSW was selected as the study area since it is the largest watershed of Santiago (the main agricultural island) that can be considered a reference for SWC works.

\subsubsection{Methodological approach}

For this study, we used a mixed methods approach, consisting of literature and policy review, qualitative and quantitative field assessment and analysis of local and scientific knowledge. Tapping into local and expert opinion formed an important part of the methodology, both to triangulate results obtained using other methods, and because measurements and observations were not always possible.

An analyses of Government actions towards building resilience against the harsh drought conditions (Section 3) was conducted through national documents, such as strategic and action plans (i.e., the United Nations Conventions on Desertification-UNCCD, Biological Diversity-CBD, and Climate Change-UNFCC), policy regulations, and project implementation reports.

Assessment and mapping of land degradation status (drivers, types, and extent), existing SLM measures (types and extent), effectiveness of measures, and expert recommendation 
of conservation measures were carried out during implementation of the DESIRE project (2007-2012) using the "DESIRE approach" (Schwilch et al., 2012).

Land degradation and existing SLM measures were mapped using the WOCAT-LADADESIRE methodology and evaluated by applying WOCAT (World Overview of Conservation Approaches and Technologies) questionnaires on SLM technologies and approaches at local level (WOCAT, 2008). WOCAT (www.wocat.net) offers a systematic methodology to assess both the institutional aspects (approaches) and practical implementation aspects (technologies) of SLM using expert questionnaires.

Detailed mapping coverage of the existing SWC measures was carried out using aerial photography (Digital Ortophotos, 2010). The extent of land degradation was determined in \% on the mapping unit, based on the land use system as the basic unit of evaluation; while the degree of degradation refers to the intensity of the land degradation process, weighted against the extent for each map unit: Degree $\times$ Extent (\%)/100.

The effectiveness of SLM measures was defined in terms of how much the measures reduce the degree, or prevent land degradation and was weighted against the extent for each mapping unit: Effectiveness $\times$ Extent $(\%) / 100$.

Expert recommendation concerning interventions on how to address degradation was based on four groups: adaptation, prevention, mitigation and rehabilitation.

Stakeholders involvement in the project was accomplished through workshops following a standard approach developed for sharing of local knowledge (Schwilch et al., 2009, 2011; Tavares et al., 2013) and through WOCAT questionnaires that generated data for the mapping.

To assess the biophysical impact of selected SWC measures (terraces, vegetation barriers and rock walls-arretos) on dryland crop yield and soil quality, thirty-six plots of $25 \mathrm{~m}^{2}$ were selected in farmers' fields, in three agroecological zones (arid, semi-arid and subhumid), during the 2010 rainy season. In each plot, maize, bean and total biomass yield and soil quality parameters (nutrients, texture, organic matter, depth of top layer, etc.) were measured and compared to untreated plots using ANOVA and LSD, assuming other drivers (i.e., yield drivers) being constant. Results of other studies were also used as evidences of biophysical impact. 


\subsection{Building resilience to challenge the harsh conditions: SLM governance Factors}

\subsubsection{Eradicating famine}

Cabo Verde's history comprises remarkable events of crop failure and food insecurity that caused widespread starvation from the 16th to the 19th centuries, registering several famines and epidemics (Ferreira et al., 2013). In the first half of the 20th century, six famines occurred, causing the starvation of more than 75,000 people (Lesourd, 1995). The famine episodes were closely associated with the occurrence of extended periods of extreme drought. The last famine in 1947-1948 caused an almost 50\% reduction of the Cabo Verde population, and Amaral (Amaral, 2007) points out that in the Santiago Island alone the population decreased by $65 \%$.

Following the 1947-1948 famine, the colonial authorities took measures to mitigate the problem. The first was to employ people locally on the so-called Frentes de Alta Intensidade de Mão-de-Obra-FAIMO (High Intensity Labor Fronts) to implement SWC measures, such as terraces, dams, afforestation and irrigation infrastructure, to reduce erosion risk, conserve soil and retain water, thus stabilizing the agricultural landscape. FAIMO was a national program that ensured jobs for thousands of people in rural areas, particularly in dry years (Haagsma \& Reij, 1993). A second measure was to expatriate people to other colonies to work in plantations. A third initiative was the installation of an agriculture technical school to guarantee technical know-how, dissemination and extension. These measures, together with large-scale emigration led to the eradication of famine from the country (Ferreira et al., 2013).

\subsubsection{Environmental awareness and actions}

The post-independence governments, facing successive dry years in the late 1970s and early 1980s, oriented their rural environmental actions towards combating desertification and land degradation by managing scarce financial resources, elaborating strategic instruments, creating proper institutional frameworks, setting policies and regulations and adhering to regional and international agreements. The establishment of an environmental restoration strategy was linked to political, cultural and economic objectives as the governments aimed to reduce rural poverty by creating jobs and reducing the rural exodus. 
Financial resources management. From 1975 to late 1990s, Cabo Verde received food aid which, in agreement with international donors, was internally commercialized to support development, with a large sum of the revenue channelled to SWC works and afforestation programs implemented through FAIMO (Haagsma \& Reij, 1993; Querido, 1999; Ferreira et al., 2013). The country also benefited from programs and projects with watershed development components such as: Community-based Project for the Development of Agriculture and Livestock (PRODAP/FIDA, 1993-1997), Watershed and Applied Research Development (WARD, 1993-1997), and the Millennium Challenge Account (MCA, 20072011), that contributed to implementing SWC works throughout the islands. Nowadays a large share of the Ministry of Rural Development's (MDR) budget is still being channelled to SWC through watershed planning and management projects, but the funds come from government loans for development.

National Instruments: The successive post-independence Governments defined instruments for the implementation of a national development strategy, aiming to mainstream environmental issues in the planning process to eradicate poverty and to promote sustainable development (NAPA, 2007). The most relevant ones are: The National Development Plans (PND); the Growth and Poverty Reduction Strategy (DECRP I: 2004-2007, II: 2008-2011, III: 2012-2016); the National Environmental Action Plan (PANA II: 2004-2014); the National Program to Combat Poverty (PNLP 1996-2008); the National Adaptation Program of Action (NAPA 2008-2012); the Agricultural Development Strategic Plan (PEDA: 2004-2015); and the National Action Plan to Combat Desertification (PAN-LCD: 1998). PANA II, which promotes natural resources management, the use of efficient techniques, local participation in the sustainable use of natural resources, sustainable management of biodiversity and defines policies for food security, incorporates the objectives of PAN-LCD. For more than 10 years, the UNCCD offered the outline of a global framework in the fight against desertification and Cabo Verde has been positively evaluated for its implementation. Cabo Verde is currently updating its PAN-LCD, aligning it with the UNCCD 10-year strategic plan (2008-2018).

Regional and international agreements: At regional level, Cabo Verde is a member of CILSS (Permanent Interstate Committee for Drought Control), which is the regional organization for the formulation, analysis, coordination and harmonization of strategies and policies on food security and combating the effects of drought and desertification in the Sahelian countries. At the international level, the country is a member of the three United Nations Conventions (CBD, UNFCC, and UNCCD). The fact that Cabo Verde was the first African country and the second in the world to ratify the UNCCD in 1995 (DGA, 2004) shows the strong commitment towards combating desertification, protecting the natural resources and fighting poverty in the country. 
Institutional context. Combating land degradation through SWC measures constitutes the main pillar of the sustainable rural development strategy in Cabo Verde. An institutional framework has been set up, adapted and strengthened through the years, to support both the current activities of rural development and UNCCD implementation. Currently, MDR is the coordinating institution and an umbrella organization of key departments such as the Direction General of Agriculture and Rural Development (DGADR); the National Institute of Agriculture Research and Development (INIDA), the National Institute of Rural Engineering and Forest (INERF/SONERF) and the National Institute of Water Resource Management (INGRH/ANAS). MDR collaborates with the Ministry of Environment, Housing and Territory Management (MAHOT) for crosscutting environmental issues.

Participatory approach. Stakeholders' participation in the post-independence implementation of SWC measures went through three major phases (DGA, 2004):

- From 1975 to 1985 , participation of the population was achieved through FAIMO, which were institutionalized employment schemes that provided people with temporary paid work to alleviate their immediate household needs. The employment scheme and the top-down approach created their own dynamics: while successful in mobilizing the participation of land users, they led to a lack of perceived responsibility by landowners to maintain the structures (Haagsma et al., 1993), with consequences for the effectiveness of environmental conservation (Querido, 1999).

- From 1985 to 1995 , in an attempt to change the concept of FAIMO by diversifying rural livelihood sources and introducing more participation of local people, there was some involvement of the stakeholders, particularly land users. However, it was not an effective participation since the approach did not emphasize participation as a process. Stakeholders' participation, as a process, needs to be supported by an approach that emphasizes empowerment, fairness, trust, and learning (Pretty, 1995). Thus, this can be considered a transitional phase to an effective stakeholders' participation.

- From the late 1990's onwards, the ratification of the UNCCD harnessed the participation of local communities in drawing up a national action program to combat desertification (PAN-LCD). Since then, a full partnership with the population has been established, with community-based organizations playing a major role not only in implementing and maintaining SWC works, but also in contributing local knowledge and choosing the best local measures.

There is general consensus that success in combating land degradation and natural resource management can best be achieved with active involvement of affected populations in developing solutions, leveraging their knowledge and experiences and combining them with the knowledge of researchers and managers in all planning steps 
(Reed et al., 2005; Stringer \& Reed, 2007; Reed, 2008; Reed et al., 2011; Schwilch et al., 2012b; Mutekanga et al., 2013; Tavares et al., 2013).

In addition, taking the watershed as the planning unit, with full involvement of community associations and farmers, has enabled the capacity of local people to implement major rural engineering SWC works. Thus, SWC activities acquired new dynamics, moving from essentially work provision schemes to effective participation in both building and maintenance of SWC measures.

Stakeholders' awareness, training and capacity building. Since the 1990s, an increasing attention was paid to awareness, training and capacity building of stakeholders on environmental conservation, which has positively influenced the success of SWC in the country. Stakeholders have become more conscious about the need for SWC and maintenance. Technical capacity building was crucial for executing engineering works. Currently, all environmental projects include awareness, training and capacity building activities for stakeholders.

As a result of these governance aspects, Cabo Verde is currently recognized as a success case on transforming a harsh environment into a less hostile living environment and building resilience to absorb shocks from extreme drought periods, which no longer result in deaths due to starvation (DP2012/PLEIN/11, 2011), and is currently pursuing a new development paradigm. New solutions have to be sought to provide food for a fast growing population, while intensifying soil productivity on highly degraded land and this should pass through the endorsement of SLM strategies.

\subsection{Drivers of land degradation and desertification}

Land degradation in Cabo Verde, particularly in Ribeira Seca, results from a combination of climate, human and topographic factors.

Climatic drivers. Extended droughts have reduced vegetation cover, exposing bare land to erosion, while heavy rainfall events during the wet season generate high rates of runoff transporting enormous quantities of soil. Erosion by water (i.e., 43 and $23 \mathrm{Mg} \cdot \mathrm{ha}^{-1} \cdot \mathrm{yr}^{-1}$, at watershed and plot levels, respectively) seriously affects the quality of the environment, food security, sustainability and longevity of the limited arable land in the RSW (Querido, 1999; Tavares \& Amiotte-Suchet, 2007).

Human drivers. In RSW, human activity exerts strong pressure on the limited land and water resources, contributing to land degradation in several ways (INIDA-DESIRE, 2008): 
(a) Inadequate agricultural practices such as intensive cultivation of steep slopes without adequate conservation measures and excessive weeding by hoe; (b) Overexploitation of the aquifers, through over-pumping of wells, which has resulted in sea water intrusion, leading to the salinization of soil and water in the valley bottom. Salinity has affected soil and water quality up to about $2.5 \mathrm{~km}$ from the coast into the valley; (c) Construction of the Poilão dam ( $2 / 3$ of the way to the sea) has blocked the aquifer movement downstream and also contributed to salinization of the lands close to the sea; (d) rural poverty, leading to deforestation due to tree cuttings for domestic use as energy for cooking; and excessive grazing by animals.

Topographic and pedological factors. Rainfall is strongly influenced by elevation, with highest erosivity values at high elevations, coinciding with steep slopes and shallow soils, which make these areas susceptible to erosion (Sanchez-Moreno, 2014). Despite the natural fertility of the soils due to their volcanic nature, intensive cultivation without replenishment of soil nutrients has resulted in the decline of fertility in the dryland soils. Since farmers do not apply any fertilizers on dryland soils, the only source of nutrients for the maize crop comes from the intercropped beans, which is not sustainable.

These driving forces place pressures on the land and have particular impacts at different levels. Cabo Verde society and authorities have already produced some responses to those impacts and also seek better knowledge on how to respond. Decisions on responses are governed by a range of international, national and local policy regulations and agreements (see Section 3). Nongovernmental Organizations (NGOs), governments and civil society are working together in natural resource management to combat environmental degradation through reduction of poverty, as it is believed that, by reducing poverty, the pressure on natural resources will also decrease environmental degradation. 


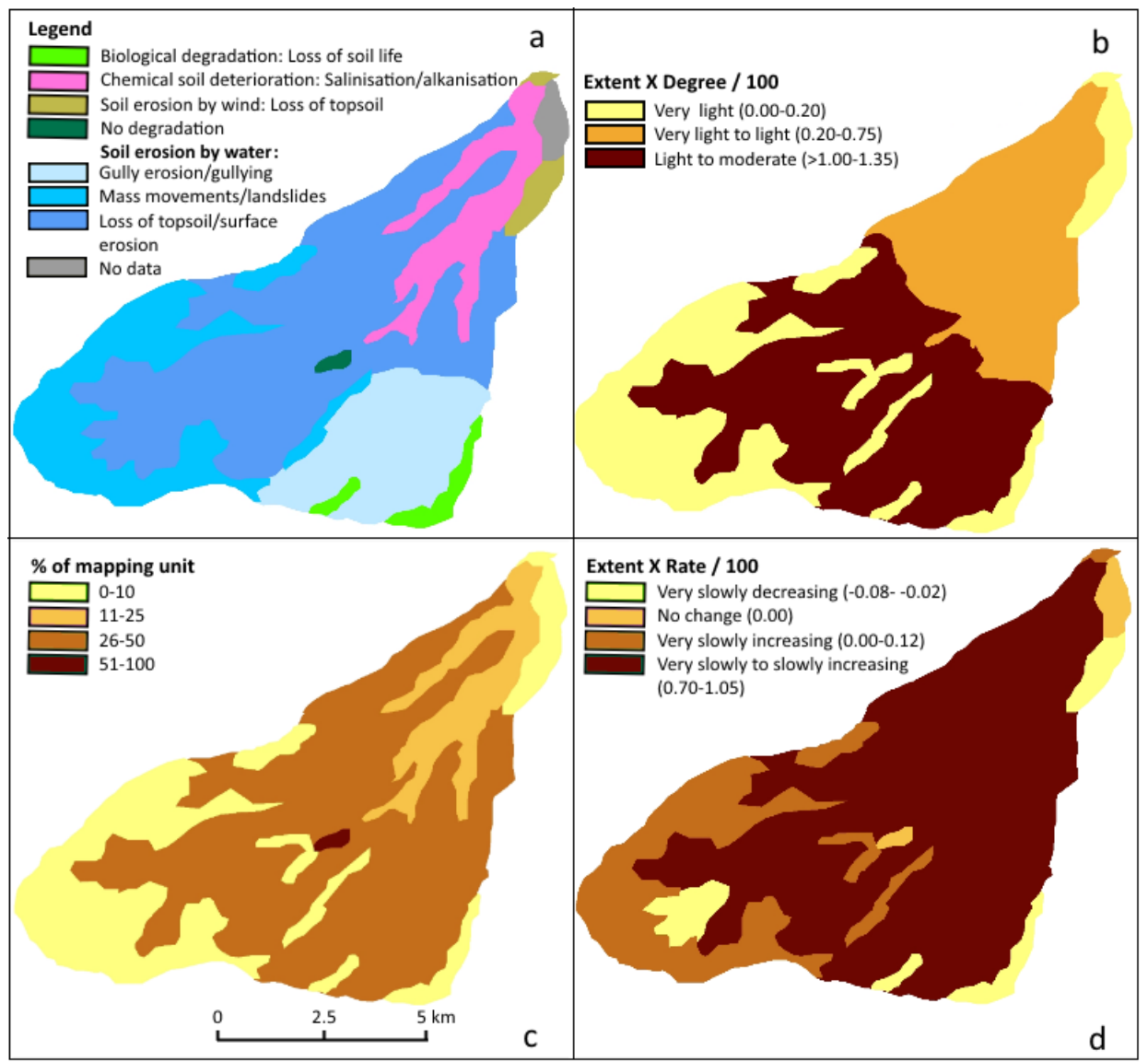

Figure 2.4 Type (a), degree (b), extent (c) and rate of land degradation (d) in the Ribeira Seca Watershed, showing water erosion as the dominant type, moderate degree, and slight to moderate rate of degradation. Adapted from (www.desire-his.eu).

\subsection{Status of land resources and management}

\subsubsection{Monitoring and assessment in the Ribeira Seca Watershed}

Monitoring and assessment (M\&A) of SLM measures in Cabo Verde are at an incipient stage, with few environmental projects containing these important components. Most projects lack a scientifically robust and consistent baseline, which is a key constraint to identifying priorities for action and monitoring their impact. This paper focuses on the implementation of the DESIRE project. 
The bottom-up Desire approach to combat desertification advocated SLM based on inventories of local knowledge using an integrative participatory approach in close collaboration with local stakeholders, but with a sound scientific basis for effectiveness at various scales (Schwilch et al., 2012). With the completion of the project, the data from RSW is part of a web-based harmonized information system (www.desire-his.eu) featuring the: socio-cultural, economic and environmental context; stakeholders goals and drivers of changes; status of land degradation and land management; identification, documentation and evaluation of SLM options; prioritization and selection of remediation options; field trials of SLM techniques with scientific and stakeholders' monitoring; biophysical and economic effects at field and regional scale; evaluation of options and recommendations; and strategy for disseminating recommendations at various levels. Given the DESIRE project's limited duration of five years, its methods, experiences, and expertise should be integrated into long-term programs (i.e., UNCCD) to ensure their continued use and ultimate effectiveness.

\subsubsection{Type, degree, extent and trend of land degradation and desertification risk}

The RSW presents physical land degradation in various forms, degree, extent and rate (Figure $2.4 \mathrm{a}-\mathrm{d}$ ). The degree of degradation is light to moderate, possibly due to the large extent of conservation measures, covering $80 \%-100 \%$ of the cultivated rain-fed land. The main type of land degradation is water erosion, estimated to affect $26 \%-50 \%$ of the watershed area under subsistence rain-fed agriculture, manifesting first as loss of top soil, second as mass movement and third as gullies. Chemical degradation due to salinization in cultivated land under irrigation is also significant, affecting $11 \%-25 \%$ of the surface area. Wind erosion and biological degradation, associated to the loss of top soil and soil life, are less significant and affect $0 \%-10 \%$ of the RSW.

The rate of land degradation on the hillsides, as indicated by the trend over the recent past 10 -year period, was estimated as very slowly to slowly increasing.

\subsubsection{Magnitude of soil erosion}

Several attempts have been made to quantify erosion in the RSW both at plot (Barry et al., 1995; Querido, 1999; Smolikowski et al., 2001; Baptista et al., 2015b) and sub-watershed levels (Mannaerts, 1986; Sabino, 1990; Lopes \& Meyer, 1993; Mannaerts, 1993; Tavares, 2010), with results indicating great spatial and temporal variability depending on slope, 
land-use, rainfall amount and intensity. Mean erosion rates $\mathrm{Mg} \cdot \mathrm{ha}^{-1} \cdot \mathrm{yr}^{-1}$ ) for traditional farming vary from 0.2 to 23 at plot level and from 0.1 to 43 at sub-watershed level under natural rainfall (Table 2.1). The smaller rates at plot level correspond to low slope areas and the larger to the steeper slopes. Given the large variability within the results, the high rates of erosion and the shallow soils on steep terrain, there is a need to carry out longer term assessments and to establish standard tolerable rates for Cabo Verde hillsides, allowing policy makers to better plan SWC interventions.

Table 2.1 Mean rates of soil erosion in the Ribeira Seca Watershed at different scales and periods.

\begin{tabular}{|c|c|c|c|c|}
\hline Scale/Location/\% Slope & $\begin{array}{c}\text { Period of } \\
\text { Measurements }\end{array}$ & $\begin{array}{c}\text { Land Use/Conservation } \\
\text { Measure }\end{array}$ & $\begin{array}{l}\text { Magnitude } \\
\left(\mathrm{Mg} \mathrm{ha}^{-1} \mathrm{yr}^{-1}\right)\end{array}$ & Reference \\
\hline $\begin{array}{l}\text { Sub-watershed: Seca (variable } \\
\text { slopes) }\end{array}$ & 1985-1989 & $\begin{array}{c}\text { Mixed land-use/Check } \\
\text { dams }\end{array}$ & 4.66 & $\begin{array}{c}\text { (Lopes \& } \\
\text { Meyer, 1993) }\end{array}$ \\
\hline $\begin{array}{l}\text { Sub-watershed: Longueira } \\
\text { (variable slopes) }\end{array}$ & \multirow{3}{*}{ 2005-2009 } & \multirow{3}{*}{$\begin{array}{l}\text { Mixed land-use and } \\
\text { conservation measures }\end{array}$} & 42.7 & \multirow{3}{*}{ (Tavares, 2010) } \\
\hline $\begin{array}{c}\text { Sub- } \\
\text { watershed/Grande/variable } \\
\text { slopes }\end{array}$ & & & 1.57 & \\
\hline $\begin{array}{c}\text { Sub-watershed: Godim/variable } \\
\text { slopes }\end{array}$ & & & 0.10 & \\
\hline Plot/O. Pequeno/ $\leq 37$ & \multirow{3}{*}{ 2011-2012 } & \multirow{3}{*}{ Maize and beans } & $9.10(16.6)^{*}$ & \multirow{3}{*}{$\begin{array}{c}\text { (Baptista et al., } \\
\text { 2015b) }\end{array}$} \\
\hline Plot/Serrado/ $\leq 23$ & & & $2.13(3.21)^{*}$ & \\
\hline Plot/S. Jorge/ $\leq 8$ & & & $0.30(0.4)^{*}$ & \\
\hline Plot/Godim)/50 & 1994-1996 & Maize and beans & $16.0(48)^{* *}$ & $\begin{array}{l}\text { (Smolikowski et } \\
\text { al., 2001) }\end{array}$ \\
\hline Plot/Godim/35-60 & & Maize and beans & $23(69)^{* *}$ & (Querido, 1999) \\
\hline
\end{tabular}

* Maximum rates; ${ }^{* *}$ total for period.

\subsubsection{Existing land management measures}

Ribeira Seca is one of the watersheds in the country where most SWC measures, both structural and biological (vegetation), were implemented. Structural techniques comprise check dams, contour rock walls, contour furrows, micro catchments, terraces, water reservoirs and retaining dams (Figure 5a). Biological techniques consist of vegetation barriers with different species (i.e., Aloe vera, L. leucocephala, F. gigantean), pigeon pea cultivation and reforestation with drought-tolerant species. Vegetative measures, including tree/shrub cover, implemented to protect the steep hillsides, are most widespread and cover more than $80 \%$ of the watershed area (Figure $2.5 \mathrm{~b}, \mathrm{c}$ ). Along the valley bottom and the steep water lines, about 200 check dams are present, contributing to decrease runoff rate and increase infiltration. The implementation of SWC techniques modifies landscape functions at different spatial scales (Wakindiki and Ben-Hur, 2004) and in Cabo Verde they have produced dramatic changes both at plot and watershed scales. 
Figure 2.6a-h) illustrates some relevant SWC measures in the watershed, some of which (i.e., afforestation and Aloe vera hedges) were documented as successful and promising conservation measures (Liniger et al., 2011; Schwilch et al., 2012).

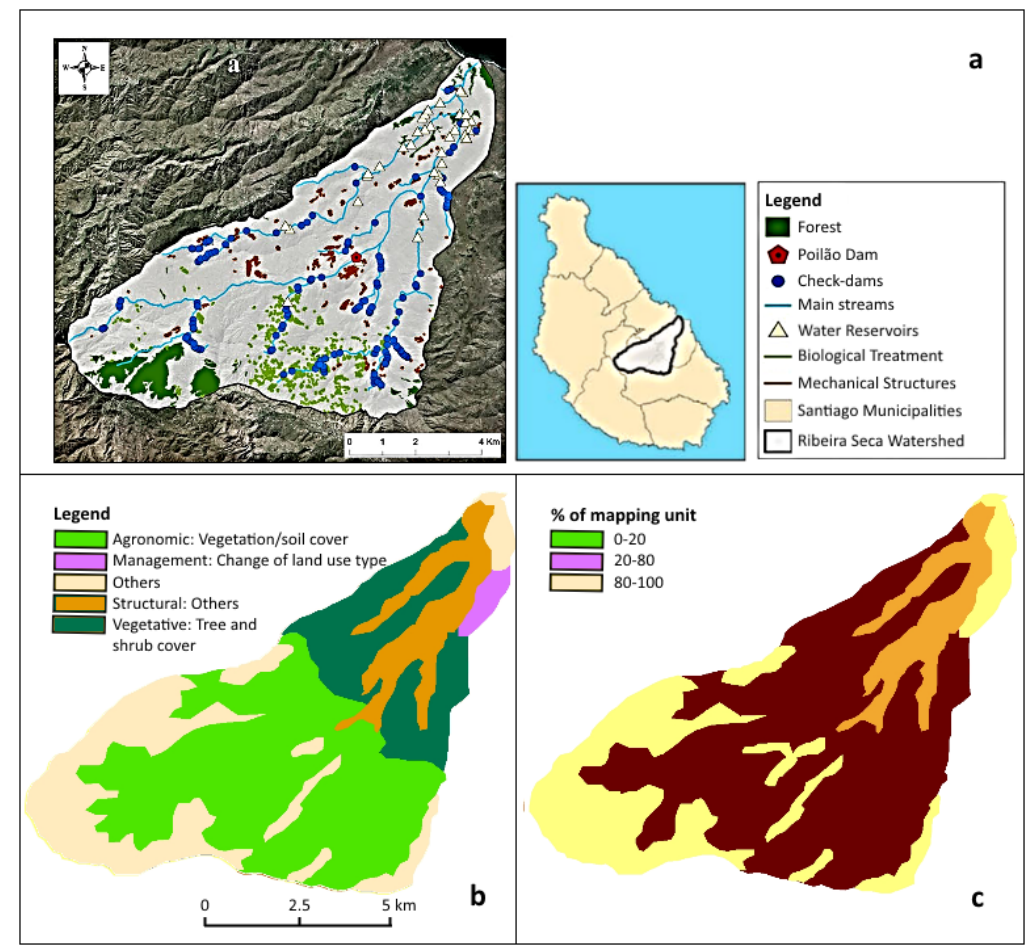

Figure 2.5 Existing soil and water conservation measures (a), land conservation group measures (b) and extent as \% of mapping unit showing the importance of vegetation measures as the major conservation group at hillslope level (c). $b$ and $c$ adapted from (www.desire-his.eu).

Recently, the government constructed large dams to collect and store runoff from the watersheds, with five dams already built in the two largest islands. Ribeira Seca encloses one of the largest rainwater collecting dams built in the country, with a capacity of 1.2 million $\mathrm{m}^{3}$. The construction of this large piece of infrastructure (see Figure 2.6c). completely changed the surrounding landscape, allowing 188 ha of irrigated land. Drip irrigation was introduced in the 1990's as a more efficient and water saving irrigation system, and has been promoted since. In rain-fed areas in the downstream section of the watershed, large concrete water reservoirs were built to collect and stock rain water for supplementary irrigation, human and animal consumption (DGA, 2004; INIDA-DESIRE, 2008; Ferreira et al., 2013). 

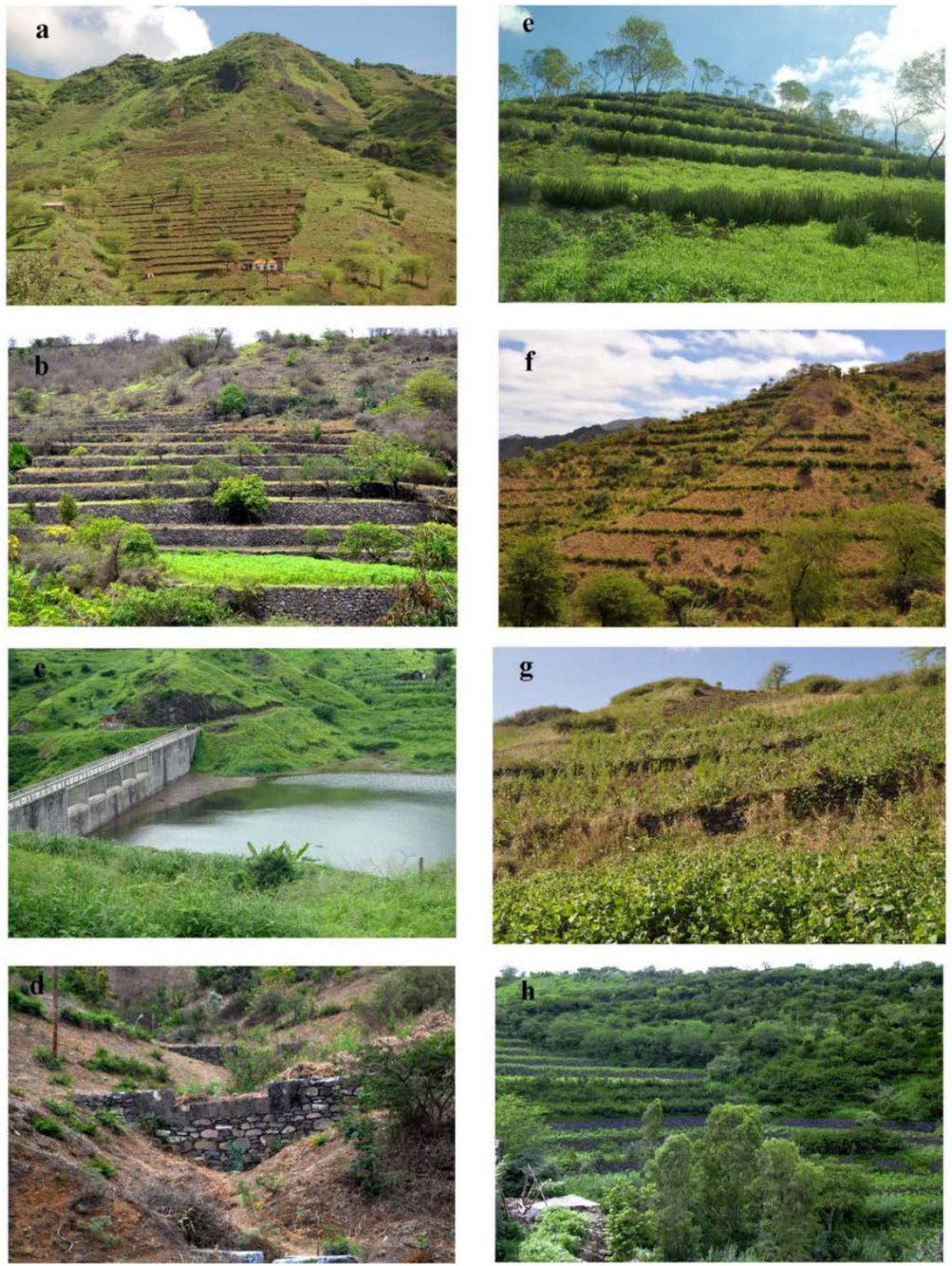

Figure 2.6 Vegetation and structural soil and water conservation measures in the Ribeira Seca Watershed: contour rock walls (a); terraces in São Jorge (b); Water collecting dam (Poilão) during rainy season (c), check dams on water ways in Godim (d); Aloe Vera barriers in São Jorge (e); L. Leucocephala hedges (f); Pigeon-pea on terraced fields (g); and Afforestation with different species in Longueira Baixo (h). 
Afforestation (Figure 2.6h) with numerous drought-tolerant species is one of the key techniques to address land degradation and has increased from <3000 ha in 1975 to 92,000 ha in 2012 . It provides soil protection against erosion, fuel wood for cooking and animal feed, and enables better use of rainfall for increased crop productivity. Moreover, the large afforested area has conveyed more green color to the "lunar" aspect of the landscape. The total biomass production has reached 800,000 ton in Cabo Verde and the total carbon sequestered in the biomass, 402,500 ton with Santiago Island contributing with $60 \%$ of the total (DGASP, 2013).

\subsection{Effectiveness and impact of SWC}

\subsubsection{Effectiveness for slope protection and soil cover}

Though the few studies carried out to evaluate the impact of SWC techniques on slope protection are not consistent, there is a consensus that the techniques implemented in the last half century played a positive role in the fight against land degradation (Querido, 1999; Ferreira et al., 2013; Tavares et al., 2013). The effectiveness of SWC measures refers to indications of how much or how well the measures reduce or prevent degradation (Schwilch et al., 2012). The area of the watershed under rain-fed agriculture shows moderate to high effectiveness of the implemented measures (Figure 2.7a) with an increasing efficiency trend (Figure 2.7b). A small area, corresponding to the irrigated land at the valley bottom, shows low to very low conservation effectiveness with a slightly increasing trend. Although $>80 \%$ of the watershed benefits from conservation measures, their effectiveness trend shows the need for additional SLM measures, either as mitigation, prevention, rehabilitation or a combination, according to the land use type [WOCAT, 2008). For the valley bottom, affected by salinization, mitigation of the problem and prevention of further degradation are recommended; for the biological degradation with loss of soil life at high elevation, mitigation measures are recommended; for the severe loss of top soil in the upstream part of the watershed, a combination of mitigation, rehabilitation and rehabilitation measures is recommended; while downstream rehabilitation measures are recommended (Figure 2.7c). 


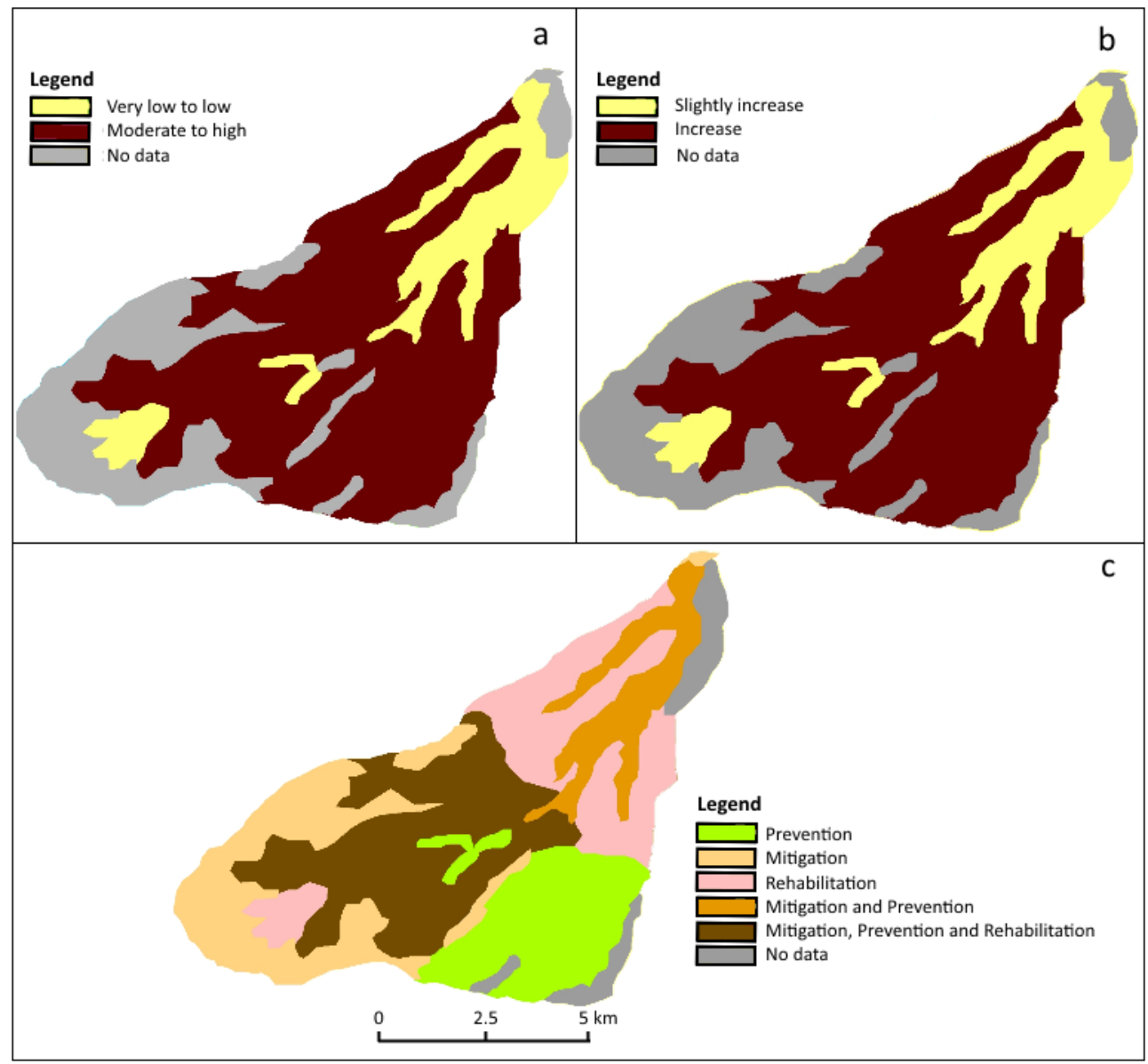

Figure 2.7 Effectiveness of conservation measures in the Ribeira Seca Watershed, weighted by area, evidencing the moderate to high effectiveness of the implemented measures at slope level (a), the increasing conservation efficiency trend on the slopes (b) and expert recommendation on measures (c). Adapted from (www.desire-his.eu).

At hillslope level, Ferreira et al. (2013) reported a positive effect of different SWC techniques (i.e., vegetation strips, afforestation, terraces, contour stone walls and vegetation strips) on parameters like soil compaction, erosion index, rock outcrops and stone, organic matter, vegetation cover and soil accumulation. Smolikowski et al. (2001) showed the effectiveness and the importance of vegetation barriers and mulch against water erosion when compared with traditional cropping practices (maize and beans),

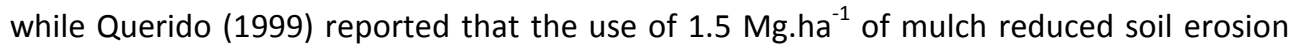
by up to $95 \%$ and significantly increased infiltration. Baptista et al. (2015b) also reported 
up to $100 \%$ reduction in soil loss from steep dryland hillsides with a combination of crop residue mulching, pigeon-pea hedges and organic amendments.

Agronomic trials of pigeon-pea runoff barriers under the DESIRE project (DESIRE, 2011) resulted in positive ecological impact such as $28 \%$ reduction in area with erosion rates $>10$ $\mathrm{Mg} \cdot \mathrm{ha}^{-1} \cdot \mathrm{yr}^{-1}$ and $>20 \%$ increase in both water availability and ground water recharge. As off-site impact, $>20 \%$ reduction in flooding and $20 \%$ less stream discharge were also reported. However, these experimental results have not been applied at larger scale.

\subsubsection{Impact on crop yield}

Impact studies of techniques on dryland crop productivity carried out by INIDA have turned out inconsistent through the years, depending on yearly rainfall and agroecological zone. In 2005, a year considered of deficient rainfall both in amount and distribution, a significant increase of $87 \%$ was registered for maize grain and biomass yield for contour stone walls when compared to non-treated plots, assuming other yield drivers constant (INIDA, 2006). However, this significant increase was only verified in the semiarid agro-ecological zones and not in humid, sub-humid or arid zones.

Table 2.2 Some indicators of biophysical impact of pigeon-pea technology in the Ribeira Seca Watershed (RSW) at field scale. Source: (DESIRE, 2011; Tavares et al., 2013).

\begin{tabular}{cccc}
\hline Parameter & Before Technology & Year 1 & Year 2 \\
\hline Soil cover (\%) & $<1$ & 35 & $48-87$ \\
Dry organic mulch (\%) & $<5$ & 31 & 60 \\
Grain yield (Mg.ha ${ }^{-1}$ ) & $<0.2$ & 1.9 & 1.8 \\
Biomass (\% increase) & & 115 \\
\hline
\end{tabular}

On the other hand, in 2010, a year of good rainfall amount and distribution, none of the assessed SWC measures (terraces, vegetation barriers and contour rock walls) resulted in a significant increase in maize, bean or biomass yield, in any of the three agro- ecological zones, when compared with untreated field plots. Likewise, no significant effect on soil quality parameters such as nutrients availability, depth of topsoil and organic matter was registered. The positive water balance observed during the growing period, indicating that soil moisture was not limiting crop yield, could explain the absence of an increase in yield. However, since overall mean crop yields were low $\left(0.6\right.$ and $0.3 \mathrm{Mg} \cdot \mathrm{ha}^{-1}$ for maize and bean, respectively), other factors such as low soil fertility (i.e., $\mathrm{N}$ and $\mathrm{OM}$ content) might also have influenced crop development and yield (Varela, 2012). 
Other researchers (DESIRE, 2011; Tavares et al., 2013) reported increased biophysical impact of the implemented pigeon-pea (Cajanus cajan) technology in RSW, at field scale trials, compared to without implementation (Table 2.2). Soil cover increased up to $87 \%$, dry mulch by $60 \%$, grain yield by $89 \%$, and biomass production by $115 \%$ after the second year of implementation.

To improve the quality of biophysical impact assessment of SWC measures on crop yield, there is a need for a more systematic and longer-term evaluation, allowing the establishment of a more consistent trend based on rainfall amount and distribution, agroecological zone and soils characteristics.

\subsection{Sustainable rural livelihood}

\subsubsection{Livelihood approach to soil and water conservation}

The SWC measures implemented contributed to the improvement of the economic and environmental conditions of the treated lands in Cabo Verde by making crop production possible, and consequently improving the livelihood of the people. The SLM measures implemented in the RSW have, to a great extent, imparted resilience to the agroecosystems, making them able to resist droughts and land degradation as evidenced by the high effectiveness of the measures, greener landscape, more water available, slight to moderate degree of degradation and moderate risk of desertification. These positive aspects contribute to people's well-being as evidenced by farmers' testimonies showing satisfaction, for example, with the pigeon-pea technology that lead to high yield and better soil cover, with positive impacts on soil conservation, human and animal feed (Tavares et al., 2013). Evaluation of the global scenario for food production (DESIRE, 2011) shows that the pigeon-pea technology can achieve very significant yield increases, both per area $\left(2568 \mathrm{~kg} \cdot \mathrm{ha}^{-1}\right)$ and per capita $(1218 \mathrm{~kg})$, thus, reducing poverty level. Pigeon-pea technology also resulted in $50 \%$ increase in production area and $50 \%$ reduction in production risk in RSW.

In addition, surface runoff water stored in the Poilão dam $\left(1.714 \mathrm{~m}^{3}\right)$ is used for irrigation of 188 ha of land, allowing farmers to increase yield and diversify their livelihood sources of income (MDR, 2012).

Though benefits of SWC measures are in line with the sustainable rural livelihoods framework (DFID, 1999), dryland agriculture sustainability as a whole may be questioned as unsuitable conditions such as high rates of soil erosion in many parts of the country, 
low rain-fed productivity, inadequate agricultural practices and high incidence of rural poverty (>60\%), still occur.

\subsubsection{Cultural value of rain-fed Crops}

Maize was introduced in Cabo Verde from Brazil in the $16^{\text {th }}$ century and evolved as the predominant dryland crop and the preferred staple food for the population (Langworthy \& Finan, 1997). Despite the low yields (300-700 kg maize grain per ha) and frequent crop failure, farmers routinely plant maize every year, regardless of the economic loss and environmental degradation arising from this agricultural activity. Land degradation has been widely associated with dryland farming practices (Tavares et al., 2013; Baptista et al., $2015 \mathrm{~b}$ ) as the conventional maize cultivation is practiced on steep lands without SWC measures, is excessively hoe-weeded, has low soil cover and thus leads to high soil erosion rates.

Maize is at the basis of local people diet and farmers are reluctant to cultivate other cereals. Several attempts were made to introduce crops like sorghum and quinoa that research proved to be better suited for the short rainy season, but the crops were not well accepted by local people. Maize and beans production in dryland does not contribute more than $5 \%$ to rural household revenues, and some families incur net costs for their cultivation (INIDA, 2013). Moreover, the market price of imported maize and beans is lower than local production cost. Thus, the importance of dryland crops like maize and beans is more due to their cultural than economic value, making them unlikely to be substituted for crops potentially more economically valuable or that promote SLM.

\subsubsection{Importance of dryland Production for rural family food security}

Rain-fed maize production in Cabo Verde does not cover more than $10 \%-15 \%$ of consumption in a normal rainfall year (FAO, 2007); nonetheless, it plays a crucial role in guaranteeing food security of the rural families. Firstly, it provides food grain (maize and beans) for family consumption so that in years of "good" rainfall families do not have to buy these food items for the whole year. Secondly, it provides crop biomass and stubble grazing, so the families keeping livestock do not spend money buying animal feed. Animals like goats, cattle, and pigs contribute up to $47 \%$ to the rural household income as well as food for the families (INIDA, 2013). Thirdly, rain-fed production guarantees maize and bean seeds for subsequent years, so that farmers do not have to buy them. 


\subsection{Policy oriented recommendations}

Cabo Verde's government should reinforce its policy regarding SLM practices, as they have numerous environmental, economic, and social benefits, reaching far beyond their potential to reduce land degradation and desertification. SLM also addresses global concerns such as water scarcity, resource-use efficiency, food security, poverty relief, climate change, and biodiversity conservation (FAO, 2011). These multiple benefits justify investments in SLM and may require funding schemes from different sources, especially when involving smallholder farmers and poor people.

The huge annual spending on implementation of SLM calls for concerted efforts to standardize documentation and evaluation. New efforts towards SLM should build on existing knowledge from either within the country or from similar environments elsewhere. Identifying and assessing existent knowledge on SLM and making it widely available needs a harmonized methodology for comprehensive data collection, knowledge management, and dissemination, such as the DESIRE approach applied in the RSW.

The DESIRE experience in Cabo Verde emphasized the importance of a close partnership between researchers and local stakeholders in developing and evaluating SLM options to meet local needs and priorities. Stakeholders' active involvement in the project has resulted in the application of the SLM measures tested. It is important to consider local knowledge and traditional approaches to land management together with the latest research tools (i.e., WOCAT-LADA-DESIRE mapping, DESIRE expert system, decision support tool), and to combine perceptions from both sources. Such tools can be used in reporting to UNCCD, thus contributing to the implementation of the convention in the country.

\subsection{Conclusions}

Cabo Verde has long recognized land degradation and desertification as major threats to its environment with direct impact on human well-being and social welfare. The country moved from experiencing regular crop failure and starvation to being a success case on managing a harsh environment and scarce natural resources to provide food security and improve the livelihoods of local inhabitants. Quoting the Minister of Rural Development (Mrs. Eva Ortet), allusive to the Desertification day, 2014, "Cabo Verde has successfully faced its limitations". 
The dual orientation of rural development policies towards combating desertification and reducing poverty based on massive implementation of SWC measures has resulted in building resilience to extreme drought periods.

The country's relative success in managing harsh conditions can be attributed to "good governance" in combating land degradation and desertification as evidenced by the positive evaluation of the UNCCD and DESIRE project implementation. Good governance here refers to a responsible handling of funds, an adequate framework and institutional setup, an appropriate set of instruments, the inclusion of civil society, and capacity building at national and international levels.

Although the positive impact of the implemented SWC measures on the environment, economy, food production, livelihood and combating land degradation in the country is generally acclaimed, monitoring and assessment of biophysical and socioeconomic impacts of SLM remain incipient, poorly quantified and documented, being restricted to a few isolated studies with limited scope.

There is a need for better integration of biophysical and socioeconomic aspects of SLM through a robust scientific framework. As an example of a standardized and harmonized knowledge management system, the DESIRE methodology provided a key pillar for informed decision-making at different scales by: giving SLM measures a sound scientific basis; improving indicators; assessing and developing promising SLM strategies with stakeholders; evaluating SLM measures on regional scale; and disseminating results, guidance and decision support tools suitable for all relevant stakeholders. DESIRE's methods, experiences, and knowledge should be integrated into long-term programs (i.e., UNCCD) to ensure their continued use and ultimate effectiveness. Joint commitment of all institutions, projects, and actors involved in SLM is needed to build a harmonized knowledge system for scaling up SLM. 


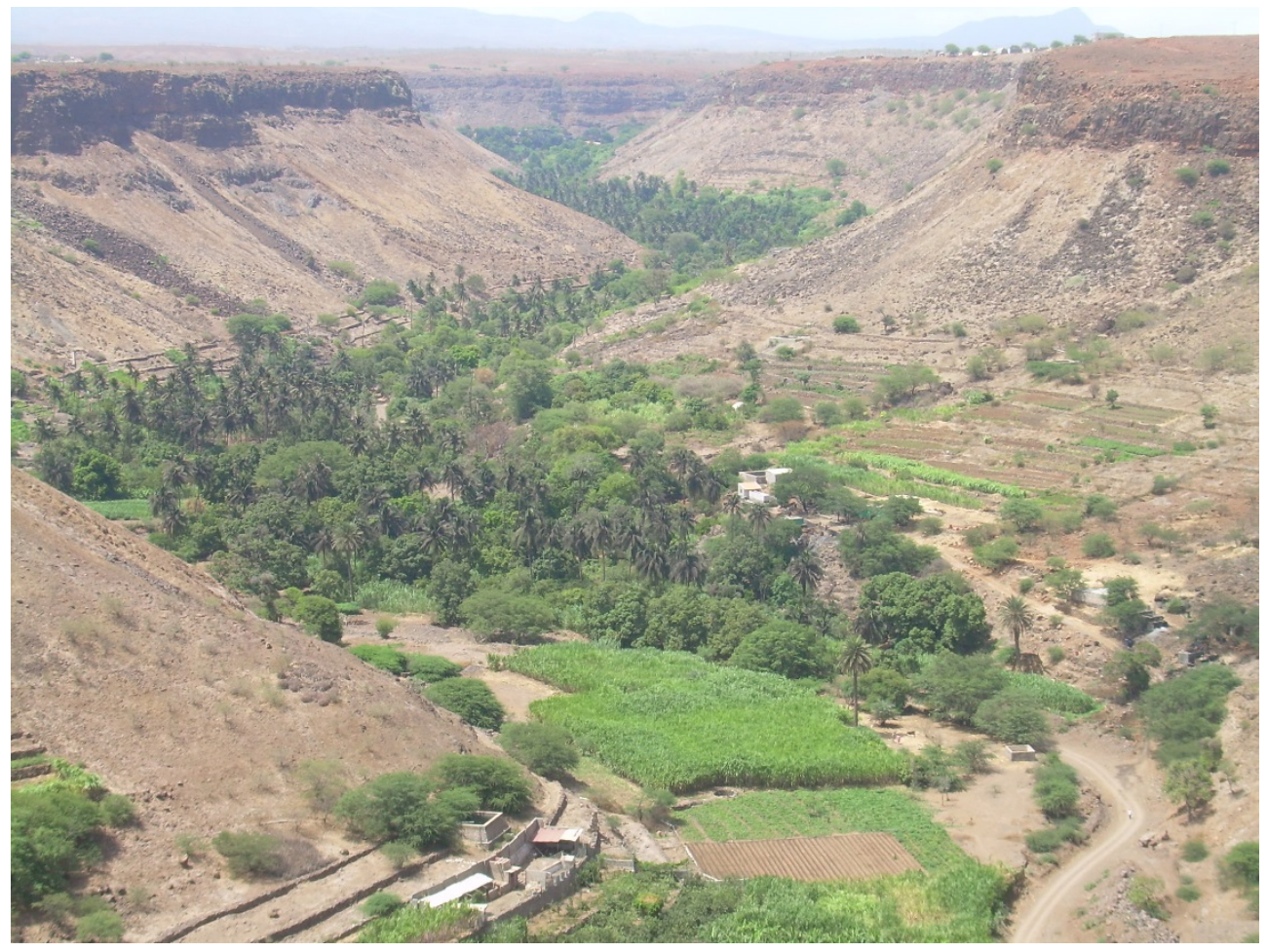




\section{Improving rainwater-use in Cabo Verde drylands by reducing runoff and erosion}

Dryland agriculture in Cabo Verde copes with steep slopes, inadequate practices, irregular intense rain, recurrent droughts, high runoff rates, severe soil erosion and declining fertility, leading to the inefficient use of rainwater. Maize and beans occupy $>80 \%$ of the arable land in low-input, low-yielding subsistence farming. Three collaborative field trials were conducted in different agroecological zones to evaluate the effects of waterconservation techniques (mulching of crop residue, a soil surfactant and pigeon-pea hedges) combined with organic amendments (compost and animal or green manure) on runoff and soil loss. During the 2011 and 2012 rainy seasons, three treatments and one control (traditional practice) were applied to $44-$ and $24-\mathrm{m}^{2}$ field plots. A local maize variety and two types of beans were planted. Runoff and suspended sediments were collected and quantified after each daily erosive rainfall. Runoff occurred for rainfalls $\geq 50$ $\mathrm{mm}$ (slope $<10 \%$, loamy soil), $\geq 60 \mathrm{~mm}$ (slope $\leq 23 \%$, silt-clay-loam soil) and $\geq 40 \mathrm{~mm}$ (slope $\leq 37 \%$, sandy loam soil). Runoff was significantly reduced only with the mulch treatment on the slope $>10 \%$ and in the treatment of surfactant with organic amendment on the slope $<10 \%$. Soil loss reached 16.6, 5.1, 6.6 and $0.4 \mathrm{Mg} \mathrm{ha}^{-1}$ on the silty-clay-loam soil $(\leq 23 \%$ slope) for the control, surfactant, pigeon-pea and mulch/pigeon-pea (with organic amendment) treatments, respectively; 3.2, 0.9, 1.3 and $0.1 \mathrm{Mg} \mathrm{ha}^{-1}$ on the sandy loam soil ( $\leq 37 \%$ slope) and $<0.2 \mathrm{Mg} \mathrm{ha}^{-1}$ for all treatments and control on the loamy soil $1<10 \%$ slope). Erosion was highly positively correlated with runoff. Mulch with pigeon-pea combined with an organic amendment significantly reduced runoff and erosion from agricultural fields on steep slopes, contributing to improved use of rainwater at the plot level. Sustainable land management techniques, such as mulching with pigeon-pea hedges and an organic amendment, should be advocated and promoted for the semi-arid hillsides of Cabo Verde prone to erosion to increase rainwater-use and to prevent further soil degradation.

This chapter is published as:

Baptista, I., Ritsema, C.J. Querido, A., Ferreira, A.D., Geissen, V. 2015. Improving rainwater-use in Cabo Verde drylands by reducing runoff and erosion. Geoderma 237-238: 283-297. 


\subsection{Introduction}

A combination of harsh climatic conditions, human pressure on limited natural resources, nutrient depletion and geomorphologic and pedological factors have led to environmental degradation in semi-arid sub-Saharan Africa (Smolikowski et al., 2001; Ryan and Spencer, 2001). Land degradation reduces water productivity at the field scale and affects water availability, quality and storage (Gao et al., 2014). The strong links between water use and land degradation and management allow the improvement of rainwater-use efficiency (RWUE) by properly managing the land through use of sustainable land management techniques and approaches (Bossio et al., 2010). RWUE is a measure of the biomass or grain yield produced per increment in precipitation (Hatfield et al., 2001). A wide range of land-management techniques is available to improve RWUE in dryland farming systems (Erenstein, 2003; Rockstrom et al., 2002, 2009; Stroosnijder, 2003, 2009, 2012; Turner, 2004; WOCAT, 2007).

The World Overview of Conservation Approaches and Technologies (WOCAT, 2007) defines land-management technologies or soil- and water-conservation (SWC) techniques as "agronomic, vegetative, structural and/or management measures that prevent and control land degradation and enhance productivity in the field". These solutions may include: mechanical structures (i.e. terraces, check dams, contour stone walls and contour ridges), biological structures (i.e. afforestation and strips of vegetation), manipulation of the surface soil (i.e. tillage, mulching and soil amendments such as surfactants, compost and animal and green manure), rainwater harvesting (i.e. reservoirs and retaining dams) and agronomic measures (i.e. drought-resistant species and varieties, short-cycle varieties, crop rotation, animal and green manures, appropriate fertilizer use, compost and weed control). These SLM practices improve soil quality (Araya and Stroosnijder, 2010, Tesfaye et al., 2014), decrease erosion (less runoff and nutrient losses) and increase infiltration (less surface evaporation) and the efficient use of green water, i.e. the fraction of rainwater used for biomass production (Stroosnijder, 2003). Some of these measures succeed under certain combinations of conditions but may fail in other settings, so they require testing under specific conditions, taking into account the perception and knowledge of the farmers.

Land degradation is a major environmental issue in Cabo Verde, an island country off the western coast of Africa. The degradation has been associated with prolonged droughts and inadequate dryland agricultural practices such as the cultivation of steep slopes and bare soils (Langworthy and Finan, 1997; Mannaerts, 1993, Tavares et al., 2013). Both a lack of rain, through drought, and excess rain, through erosion and runoff, are drivers of 
land degradation. Paradoxically, rain in this semi-arid Sahelian country is both responsible for land degradation and the limiting factor determining dryland yields.

Though dryland farming is a subsistence activity, it is very important for the livelihoods of smallholder farmers that rely on it for food production. Farmers must have a selection of integrated management options (Stroosnijder, 2003) that would provide sufficient benefits against reasonable costs and simultaneously reduce dryland degradation and maintain sustainable yields, as the application of conservations strategies depends on the farmers (Huenchuleo et al., 2012; Thapa and Yila, 2012).

Dryland farming in Cabo Verde is dominated by a continuous cultivation of maize intercropped with beans and occupies over 80 percent of the arable land. This farming system must cope with steep slopes, short and irregular rains, recurrent droughts, severe storms, water losses through rapid runoff and high rates of evaporation and increasing land degradation due to erosion and declining fertility, leading to an inefficient use of rainwater. To stop land degradation and desertification, successive governments since Cabo Verde's independence in 1975 have supported a long-term program of soil and resource conservation as a centerpiece of their agricultural policy (NAPA, 2007). The predominant SLM strategies have focused on the construction of rural structures that retard sedimentation flow and increase infiltration and the widespread reforestation of marginal soils (steep slopes and semi-arid rangeland). These strategies have included the implementation of a series of measures, both mechanical and biological with the most common ones in hillslopes being: a. terraces which are structures comprising levelled strips running across the slope at vertical intervals that potentially reduces erosion and sediment transport up to $50 \%$; b. contour stone walls which are slope stabilizing structures built along a contour line, using on-site stones that slow down runoff, promote infiltration and trap sediment; c. vegetation barriers which consist in planting lines of species, such as Aloe vera, Leucaena leucocephala and Fucraea gigantean, particularly in places without stones, impeding the erosion processes and allowing accumulation of sediments behind the vegetation barriers; $d$. vegetation surface cover which consists in the use of plants such as thorn shrubs to protect sensitive areas from overland flow; and reforestation which consists in the plantation of drought-resistant species, both as SCW measure and strategy against desertification (INIDA/DESIRE, 2008; Ferreira et al., 2012; Tavares et al., 2013). The implemented strategies do not include agronomic measures or soil surface manipulation such as mulching and soil amendments that prevent and control land degradation and enhance productivity at field scale. Thus, despite the governmental efforts to reverse the processes at the watershed scale, soil erosion, low rainwater use efficiency and land degradation are still very problematic (Tavares et al., 2013), and dryland yields remain low (FAO, 2003, 2014), even in years of sufficient annual rainfall. 
This study evaluates the effects of selected sustainable land management techniques in Cabo Verde dryland for improving the efficiency of rainwater through the reduction of runoff and soil loss from rain-fed agricultural fields. More specifically, the study tests the effectiveness of residue mulching, soil surfactant and pigeon pea barriers combined with organic amendments (i.e. compost, animal manure and green manure) on surface runoff and soil loss. The selection of the techniques combined traditional and scientific knowledge in a field-based participatory approach, with the perceptions and contributions of the farmers playing a major role.

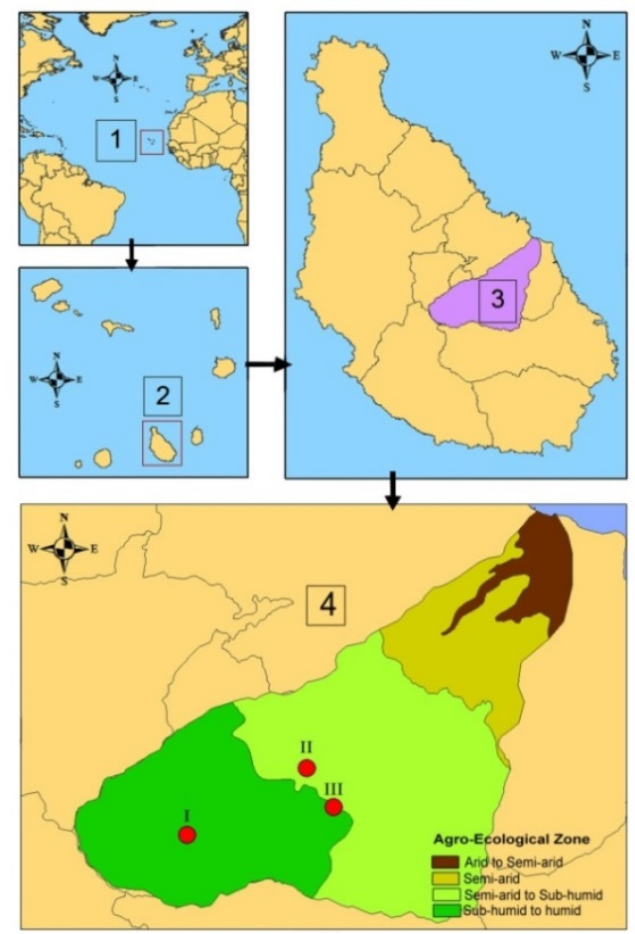

Figure 3.1 Location of (1) Cabo Verde, (2) Santiago, (3) the Ribeira Seca watershed and (4) the experimental sites and agroecological zones. I, site I (São Jorge); II, site II (Serrado) and III, site III (Orgãos Pequenos).

\subsection{Materials and methods}

\subsubsection{Study site characterization and soil properties}

This study was conducted on three sites (S. Jorge - site I; Serrado - site II; and Órgãos Pequenos - site III) of the Ribeira Seca watershed, which is the largest watershed on 
Santiago, the main agricultural island of Cabo Verde (Figure 3.1). The watershed has a drainage surface of approximately $72 \mathrm{~km}^{2}$ and extends across four agro-ecological zones of the Cabo Verde classification: semi-arid (49\%), arid (20\%), sub-humid (20\%) and humid (11\%) (Diniz \& Matos, 1986).

The climate is characterized by a dry season of 8-9 months (November-June) and a short, humid season of 3-4 months (July-October). Rainfall is extremely heterogeneous and has an irregular spatiotemporal distribution, with annual precipitation varying from $<200 \mathrm{~mm}$ downstream to $650 \mathrm{~mm}$ upstream of the watershed. The 30-years mean annual rainfall (1980-2010) was 437, 300 and $310 \mathrm{~mm}$ at experimental sites I, II and III, respectively, with most of the rain falling in August and September (INMG, 2010). The predominant land use is rain-fed (i.e. dryland) agriculture covering $>83 \%$ of the area, comprising maize, several varieties of beans and groundnuts.

The sites were selected based on their specific characteristics of soil, agro-ecological zone (AEZ), slope and agricultural practices present. Site I is characterized by a low slope $(<10 \%)$ and loamy soil on a terraced field at a research station in the sub-humid to humid zone (351 $\mathrm{m}$ a.s.l. and mean annual rainfall of AEZ of $437 \mathrm{~mm}$ ). Site II is characterized by a steep slope (37\%), a sandy loam soil and marked symptoms rill erosion on a farm, in the semiarid zone (183 $\mathrm{m}$ a.s.I. and mean annual rainfall of AEZ of $300 \mathrm{~mm}$ ). Site III is characterized by moderate to steep slopes (23\%) and a silt-clay-loam soil subject to erosion by mass flow in which the soil is protected with stone and plant barriers at field edges and is located on a farm at the junction of the semi-arid and sub-humid zones (204 $\mathrm{m}$ a.s.l and mean annual rainfall of $A E Z$ of $310 \mathrm{~mm}$ ).

The initial physical and chemical properties of the soil varied among the three sites but were homogeneous within the sites (Table 1 ) in texture, bulk density, slope and total $\mathrm{N}$ and extractable-P contents. The soils at sites I, II and III had loam, sandy loam and silt-clayloam textures, respectively. Organic-matter content was low at sites II and III and average at site I (INIDA, 1997). All sites were low in total N, particularly sites II and III with <10 mg $\mathrm{N} \mathrm{g}^{-1}$ and the extractable-P content was average to high. Bulk density varied from $1.16 \mathrm{~g}$ $\mathrm{cm}^{-3}$ at site III to $1.42 \mathrm{~g} \mathrm{~cm}^{-3}$ at site I. The soil pH was neutral to slightly alkaline. The slope was gentle at site I (8\%), moderate at site III (23\%) and steep at site II (37\%). The infiltration rate was highest at site II, followed by site I and site III, which had the lowest water infiltration. 
Table 3.1 Initial soil properties $(0-20 \mathrm{~cm})$ at the experimental sites, site slope and total seasonal rainfall in 2011 and 2012.

\begin{tabular}{|c|c|c|c|c|c|c|c|c|c|c|}
\hline Site & $\begin{array}{c}\text { Soil } \\
\text { texture }\end{array}$ & $\begin{array}{c}\text { Slope } \\
\%\end{array}$ & $\begin{array}{c}\mathrm{pH} \\
\left(\mathrm{H}_{2} \mathrm{O}\right)\end{array}$ & $\begin{array}{c}\text { Initial soil } \\
\text { moisture } \\
2011 / 2012 \\
\%\end{array}$ & $\begin{array}{c}\mathrm{Bd}^{*} \\
\mathrm{~g} \mathrm{~cm}^{-3}\end{array}$ & $\begin{array}{l}\mathrm{OM}^{* *} \\
\mathrm{~g} \mathrm{~kg}^{-1}\end{array}$ & $\begin{array}{c}\text { Total } \\
\mathrm{N} \\
\mathrm{g} \mathrm{kg}^{-1}\end{array}$ & $\begin{array}{l}P_{\text {ext }}{ }^{* * *} \\
\mathrm{mg} \mathrm{kg}_{1}\end{array}$ & $\begin{array}{c}\mathrm{K}^{* * * *} \\
\mathrm{~mm}_{1}^{-}\end{array}$ & $\begin{array}{c}\text { Total } \\
\text { rainfall } \\
2011 / 2012 \\
\mathrm{~mm}\end{array}$ \\
\hline$I$ & Loam & 8 & 7.3 & $7.1 / 7.2$ & 1.42 & 25.0 & 12.7 & 12.39 & 17.86 & $565 / 572$ \\
\hline II & $\begin{array}{l}\text { Sandy } \\
\text { loam }\end{array}$ & 37 & 7.1 & $6.8 / 6.6$ & 1.25 & 11.0 & 5.6 & 5.81 & 40.84 & $481 / 519$ \\
\hline III & $\begin{array}{c}\text { Silt-clay- } \\
\text { loam }\end{array}$ & 23 & 6.9 & $7.5 / 8.1$ & 1.16 & 15.7 & 8.6 & 8.15 & 10.67 & $549 / 540$ \\
\hline
\end{tabular}

Bd, bulk density; ${ }^{* *} \mathrm{OM}$, organic matter; ${ }^{* * *}$ extractable $\mathrm{P} ;{ }^{* * * *} \mathrm{~K}$, initial infiltration rate.

Table 3.2 Main dryland problems and solutions as perceived and prioritized by stakeholders.

\begin{tabular}{|c|c|}
\hline Priority constrains/problems & Solutions \\
\hline Soil loss, weeding with hoes & $\begin{array}{c}\text { Contour stone walls with vegetation } \\
\text { Hedges with drought-resistant species (L. leucocephala, } \\
\text { Aloe vera or pigeon-pea) } \\
\text { Direct seeding/conservation agriculture } \\
\text { Partial hand-weeding }\end{array}$ \\
\hline Weak soils (low fertility) & $\begin{array}{l}\text { Application of animal manure } \\
\text { Contour-stone walls combined with plant barriers }\end{array}$ \\
\hline Water loss by runoff & Contour-stone walls combined with hedges \\
\hline No maintenance of SWC structures & $\begin{array}{l}\text { Maintenance cost of SWC structures shared among } \\
\text { farmers and governmental institutions }\end{array}$ \\
\hline $\begin{array}{l}\text { Absence of crop rotation } \\
\text { Pest infestation } \\
\text { Intensive use of soils }\end{array}$ & $\begin{array}{l}\text { Strengthen the capacity of farmers through information, } \\
\text { training, sensitization and exchange with other farmers }\end{array}$ \\
\hline $\begin{array}{l}\text { Resistance of farmers to follow technical guidelines } \\
\text { Low involvement of young people in dryland farming }\end{array}$ & $\begin{array}{l}\text { Involvement of schools and parents/educators in } \\
\text { sensitizing youth to the importance of agriculture } \\
\text { Increase dryland productivity } \\
\text { Choice of adapted species and crop varieties based on soil } \\
\text { characteristics }\end{array}$ \\
\hline $\begin{array}{l}\text { Shortage and irregularity of rain } \\
\text { Strong, hot winds (Harmatan) }\end{array}$ & $\begin{array}{l}\text { Harvest rainwater for irrigation, converting dryland into } \\
\text { irrigated land } \\
\text { Adequate species and varieties } \\
\text { Combination with livestock production } \\
\text { Soil protection }\end{array}$ \\
\hline Shortage and high cost of field labor & Increase dryland productivity \\
\hline
\end{tabular}




\subsubsection{Selection of technologies and treatments}

The selection of treatments was based on a comprehensive review of the literature of land-management technologies in drylands and on one workshop for stakeholders. A list comprising ten techniques with the potential to increase the efficiency of rainwater within the Ribeira Seca watershed was prepared, taking into account the biophysical characteristics of the study area, the socioeconomic conditions of the farmers, the cost of the techniques and their applicability in the watershed. Most of these techniques were selected from the WOCAT database (WOCAT, 2007).

Twenty-two farmers of the Ribeira Seca watershed participated in a local workshop for stakeholders in March 2011, before the start of the field experiments. The farmers were asked to: (1) identify and group the primary constraints of dryland production, (2) discuss the list of potential technologies for addressing the primary constraints, (3) select and rank these technologies and (4) group these technologies into three categories representing low, medium and high levels of investment. The promising technologies were assessed and selected using a simplified version of the participatory approach developed by Schwilch et al. (2009) and applied by Tavares et al. (2013), which combines collective learning and decision-making with the application of evaluated global best practices.

Table 3.3 Description of the treatments applied at each experimental site

\begin{tabular}{|c|c|c|c|}
\hline Treatment & Site I (São Jorge) & Site II (Serrado) & Site III (O. Pequenos) \\
\hline $\begin{array}{c}\text { T0 } \\
\text { (Control) }\end{array}$ & $\begin{array}{l}\text { Traditional maize/bean } \\
\text { intercropping (no input) }\end{array}$ & $\begin{array}{l}\text { Traditional maize/bean } \\
\text { intercropping (no input) }\end{array}$ & $\begin{array}{l}\text { Traditional maize/bean } \\
\text { intercropping (no input) }\end{array}$ \\
\hline $\mathrm{T} 1$ & $\begin{array}{l}\text { Animal manure }\left(4 \mathrm{t} \mathrm{ha}^{-1}\right)+\text { soil } \\
\text { surfactant }\left(1 \mathrm{~mL} \mathrm{~m}^{-2}\right)\end{array}$ & $\begin{array}{c}\text { Compost }\left(4 \mathrm{t} \mathrm{ha}^{-1}\right)+\text { soil surfactant } \\
\qquad\left(1 \mathrm{~mL} \mathrm{~m}^{-2}\right)\end{array}$ & $\begin{array}{l}\text { Animal manure }\left(4 \mathrm{tha}^{-1}\right)+\text { soil } \\
\text { surfactant }\left(1 \mathrm{~mL} \mathrm{~m}^{-2}\right)\end{array}$ \\
\hline $\mathrm{T} 2$ & $\begin{array}{l}\text { Compost }\left(4 \mathrm{t} \mathrm{ha}^{-1}\right)+\text { soil } \\
\text { surfactant }\left(1 \mathrm{~mL} \mathrm{~m}^{-2}\right)\end{array}$ & $\begin{array}{c}\text { Pigeon-pea hedges + animal } \\
\text { manure }\left(4 \mathrm{t} \mathrm{ha}^{-1}\right)+\text { soil surfactant } \\
\left(1 \mathrm{~mL} \mathrm{~m}^{-2}\right)\end{array}$ & $\begin{array}{l}\text { Pigeon-pea hedges + green } \\
\text { manure ( } 1 \mathrm{t} \mathrm{ha} 1 \mathrm{~L} \text {. } \\
\text { leucocephala De Wit prunings) } \\
\text { + soil surfactant }\left(1 \mathrm{~mL} \mathrm{~m}^{-2}\right)\end{array}$ \\
\hline T3 & $\begin{array}{l}\text { Mulch ( } 4 \mathrm{t} \mathrm{ha}^{-1} \text { banana leaves) } \\
+ \text { compost }\left(4 \mathrm{t} \mathrm{ha}^{-1}\right)\end{array}$ & $\begin{array}{c}\text { Mulch ( } 4 \mathrm{t} \mathrm{ha}^{-1} P \text {. maximum grass) }+ \\
\text { pigeon-pea hedges }+ \text { animal } \\
\text { manure }\left(4 \mathrm{tha}^{-1}\right)\end{array}$ & $\begin{array}{l}\text { Mulch ( } 4 \mathrm{t} \mathrm{ha}^{-1} P \text {. maximum } \\
\text { grass) + pigeon-pea hedges + } \\
\text { green manure ( } 1 \mathrm{t} \mathrm{ha}^{-1} \mathrm{~L} \text {. } \\
\text { leucocephala De Wit prunings) }\end{array}$ \\
\hline
\end{tabular}

The farmers identified and grouped the constraints into eight main priorities and proposed solutions for each. Soil loss, low fertility and runoff from agricultural fields emerged as the three main constraints. For the three highest-priority problems, the farmers recommended the use of contour stone walls, vegetation hedges using drought- 
resistant species along contour lines, conservation farming (mulch) with partial weeding and animal manure

Based on the farmers' preferences for each study site, the selected technologies were combined into three treatments (T1-T3) which were compared to an untreated control (TO). The treatments varied among the sites, depending on the local availability of residue mulch, the source of organic amendments and the preferences of the local farmers. Each treatment contained an organic amendment (compost, animal manure or green manure) and a water-management technique (residue mulch, soil surfactant and/or pigeon-pea (Cajanus cajan) hedges

\subsubsection{Experimental set-up}

The experiments were conducted during the 2011 and 2012 rainy seasons, from August to October. The experimental plots were $11 \times 4 \mathrm{~m}$ in the two on-farm trials (Figure $3.2 \mathrm{~A}-\mathrm{C}$ ) and $6 \times 4 \mathrm{~m}$ in the trial at the research station. The smaller plot size at the research station was due to limited availability of land. Each experimental plot was isolated by a $25-\mathrm{cm}$ metal sheet hammered a few centimeters into the soil. The sheets were funneled into a large polyethylene tube at the bottom of the plots to channel the runoff water and soil loss to a covered 100- or 200-L barrel (Figure 3.2A). The experiments had a randomized design with the three treatments and one control replicated three times (Figure 3.2B).

For T1-T3, planting pits ( $20 \mathrm{~cm}$ wide and $15 \mathrm{~cm}$ deep) were dug with hoe and distanced 75 $\mathrm{cm}$ in the rows and $80 \mathrm{~cm}$ between the rows. Organic amendments (compost, animal or green manure) were applied manually to the bottoms of the pits and covered with a small amount of soil. The agricultural soil surfactant IrrigAid Gold ACA 1848 (Aquatrols, from USA) was diluted in water and sprayed on the soil surface after seeding with a handpressure pulverizer. Three types of crop residue were applied to the surface as mulch ( $4 \mathrm{t}$ $\mathrm{ha}^{-1}$ ) to cover $60-80 \%$ of the soil surface (Table 3.3 ).

The crops used in the experiments were maize (Zea mays) and two local types of beans (Vigna unguiculata, or cowpea, and Lablab purpureus, or feijão pedra). After the first significant rain (>20 mm), the crops were planted by placing three maize and four bean seeds (two of each type of bean) in each planting pit, thus forming a seed cluster. For the plots with pigeon-pea hedges (T2-T3), two pigeon-pea seeds were alternated along two lines $50 \mathrm{~cm}$ apart to form double-row hedges three meters apart (Figure 3.2A). Maize and beans were planted between the hedges. The planting density was approximately 16300 seed clusters per hectare in all plots, including the control. 
Weeds were removed from all plots twice during the rainy season, approximately three and six weeks after planting, either with a hoe or by hand, with minimum disturbance of the soil, except for the control plot, where weeding was always with hoe.

\subsubsection{Data collection and calculations}

Three composite soil samples were collected to a depth of $20 \mathrm{~cm}$ from each site at the end of the dry season before the experiments began to characterize the soil of the experimental sites. Laboratory analyses were conducted at the Instituto Nacional de Investigação e Desenvolvimento Agrário (INIDA)'s laboratory applying methods currently in use in the laboratory. These included texture by pipette method; bulk density by core method (Blake and Hartge, 1986), $\mathrm{pH}\left(\mathrm{H}_{2} \mathrm{O}\right)$ by potentiometer, EC, nitrogen ( $\mathrm{N}$ ) content by Kjeldahl digestion (Jackson, 1982), phosphorus (P) content by Olsen (Olsen and Sommers, 1982) and organic-matter content by Walkley Black (Nelson and Sommers, 1982).

Infiltration rate and soil penetrability were measured at the beginning and end of the experiments with a minidisk infiltrometer (Figure 3.2 C-4) and a hand-held penetrometer, respectively, for each treatment.

Simple rain gauges and automatic data loggers were installed at each experimental site to measure the amount and intensity of rainfall (Figure 3.2 C-3 and 5). However, due to malfunction of the data logger, it was not possible to retrieve rainfall intensity data.

The amount of runoff water in the barrels was measured after each daily erosive rainfall event (hereafter, event ${ }^{1}$ ) and $1 \mathrm{~L}$ of the suspended sediment was collected after stirring the total runoff for laboratory analysis (Sadeghi et al., 2008). The sediment was weighed after filtration and oven drying. Soil loss $\left(\mathrm{g} \mathrm{m}^{-2}\right)$ per event was determined by multiplying the sediment concentration $\left(\mathrm{g} \mathrm{L}^{-1}\right)$ by the volume of runoff $(\mathrm{L})$. Individual rates of runoff $(\mathrm{L}$ $\mathrm{m}^{-2}$ ) and soil loss per event was calculated for each treatment and added-up to obtain total seasonal rates of runoff and soil loss. The specific erosion rate per treatment, in $\mathrm{g} \mathrm{m}^{-2}$ $\mathrm{mm}^{-1}$ rain, was also calculated.

Daily rainfall erosivity, expressed as $\mathrm{El}_{30}$ parameter, was estimated using a power-law equation developed by Mannaerts and Gabriels (2001) and modified by Sanchez-Moreno et al. (2014a):

$$
E I_{30}=0.26\left(P_{24}\right)^{1.31}
$$

\footnotetext{
${ }^{1}$ Event refers to one or more rainfalls in a rainy day, with runoff and/or sediment occurrence.
} 
in which, $\mathrm{El}_{30}$ is the rainfall energy intensity or erosivity in $\mathrm{KJ} \mathrm{m}^{-2} \mathrm{~mm} \mathrm{~h}^{-1}$ and $\mathrm{P}_{24}$ the daily rainfall amount in $\mathrm{mm}$. Only rainfall amounts $\geq 9.0 \mathrm{~mm}$ were included in the calculations. Seasonal erosivity was estimated by adding daily $\mathrm{El}_{30}$ values. The reductions in total runoff and soil loss due to the treatments were calculated using the formula:

$$
R=\frac{C-T}{C} \times 100
$$

where $\mathrm{R}$ is the reduction in runoff or soil loss (in \%) and $\mathrm{C}$ and $\mathrm{T}$ are the amounts of runoff or sediment (in $\mathrm{L} \mathrm{m}^{-2}$ or $\mathrm{g} \mathrm{m}^{-2}$, respectively) in the control and treatments, respectively. The mean total runoff and sedimentation rates of the control plot were taken as the reference values $(C)$. The total yearly runoff coefficient $(\mathrm{Cr})$ was calculated for total growing-season erosive periods of rain using the equation:

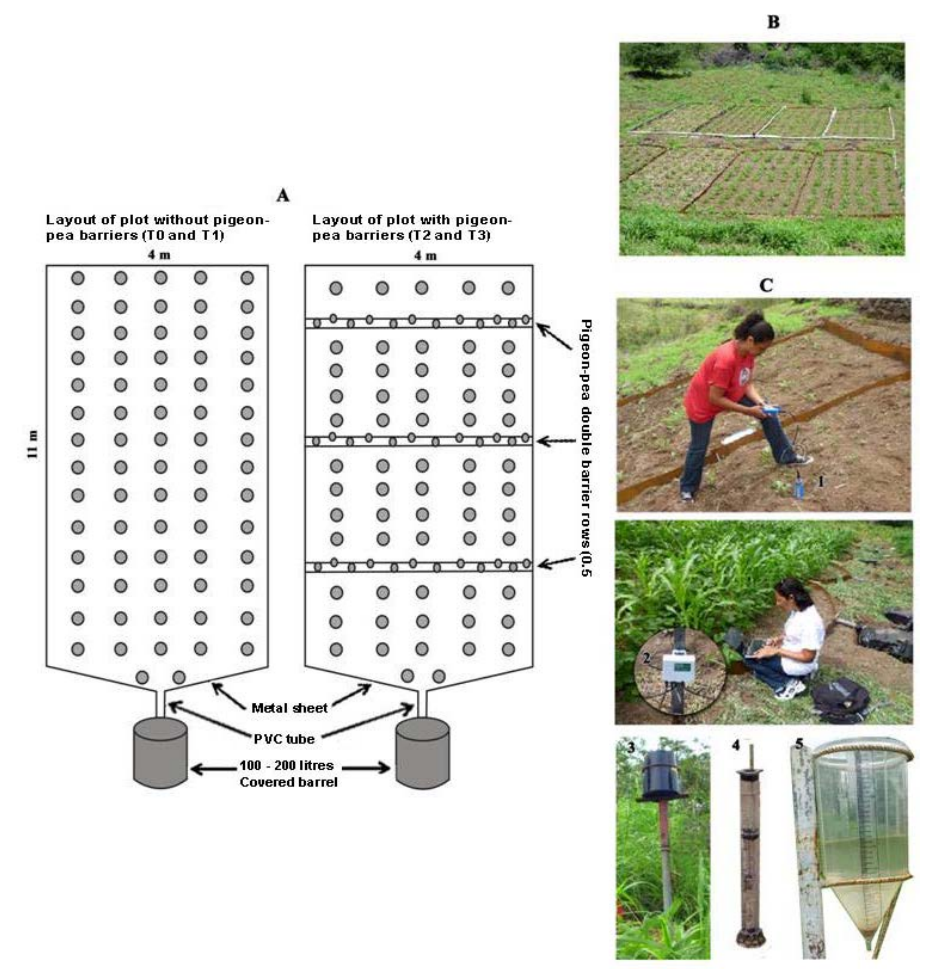

Figure 3.2 Layout and aspects of the $11 \times 4 \mathrm{~m}$ erosion plots (sites II and III). (A) Schematic layout of a plot, (B) field layout of the plots and (C) measuring instruments: 1, Trime TDR moisture meter; 2, Em5b ECH2O moisture-meter logger; 3, automatic rain gauge; 4, minidisk infiltrometer and 5, simple rain gauge.

$$
C r=\left(\frac{Q}{R}\right) \times 100
$$


where $Q$ is the runoff volume (in $\mathrm{mm}$ ) and $\mathrm{R}$ is the total rainfall producing runoff (in $\mathrm{mm}$ ).

The volumetric soil-moisture content was measured after each event at a depth of $15 \mathrm{~cm}$, both within and between the planting pits, using a TRIME ${ }^{\circledR}$ time-domain reflectrometric (TDR) moisture meter (Eijkelkamp, Giesbeek-The Netherlands) (Figure 3.2C-1).

Soil cover was estimated at each event during each season, using a modified grid method (Chambers and Brown, 1983) by placing a $1 \mathrm{~m} \times 1 \mathrm{~m}$ frame on the ground surface in each plot and visually estimating the amount of soil covered by plants and crop residue within the frame, including the applied mulch. This method was also reinforced with observations and analysis of plot photographs.

\subsubsection{Data analysis}

All statistical analyses were performed using SPSS 19.0. We used the ANOVA to test for the significance of the treatments on total seasonal runoff and soil loss that were normally distributed, and used the post-hoc Dunnett's T3 test for non-homogenous variances to identify significant differences among the treatments. The runoff and soil loss data for rainfall event were not normally distributed following the KS test, so we tested for significant differences among specific treatments for each site using the non-parametric Kruskal-Wallis and Mann-Whitney U-tests. We performed all tests applying a probability value of 0.05 . A principal component analysis (PCA) of treatment, soil cover, total runoff, total sediment, site slope, rainfall amount, soil moisture in the planting pits and soil penetrability was conducted, and components with eigenvalues over Keiser's criterion of 1 were extracted.

Correlation and regression analysis of the different variables were also performed. The data were split by site and event for analysing the treatment effect on runoff and soil loss throughout the rainy seasons. 

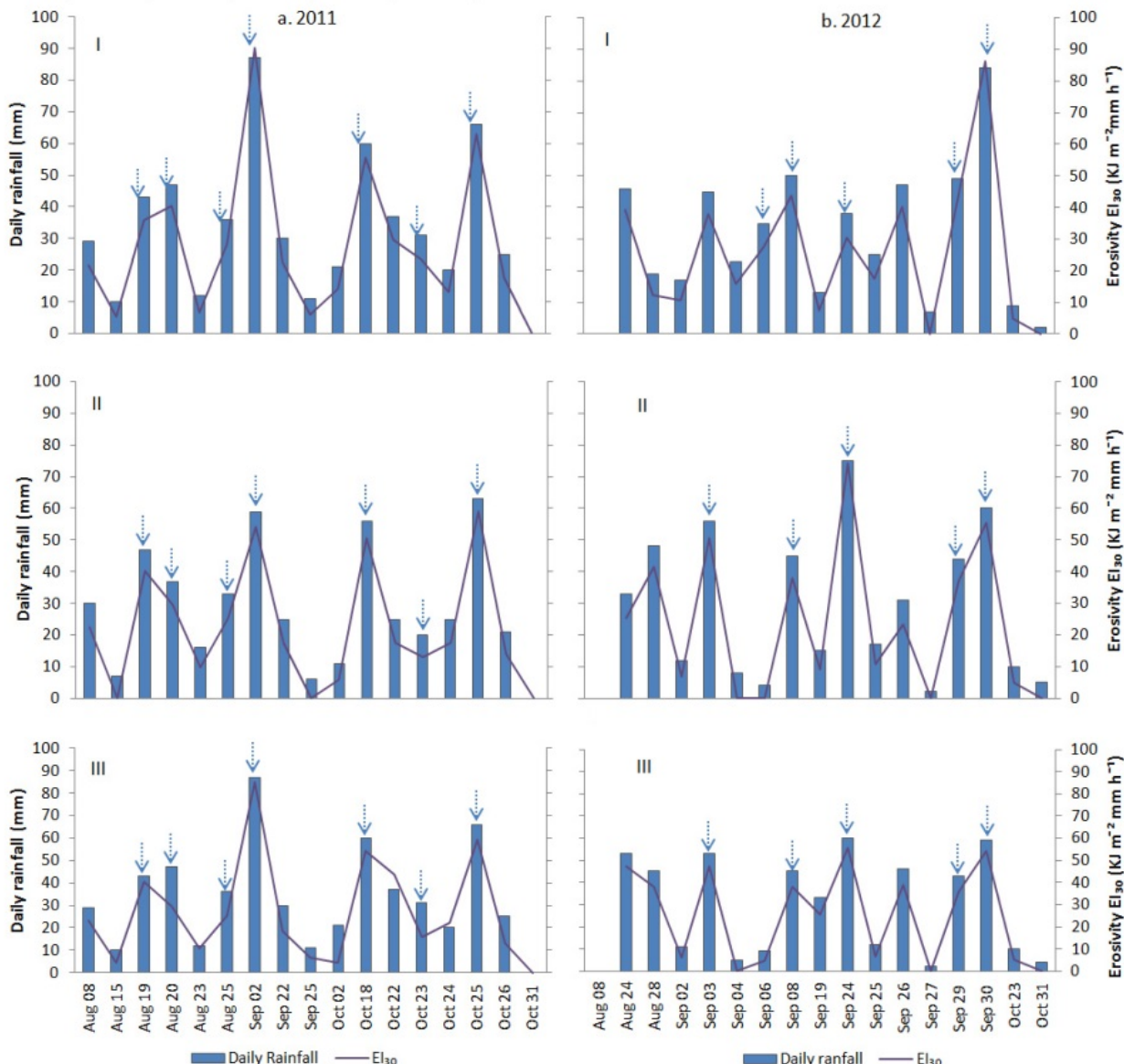

Figure 3.3 Daily rainfall distribution and daily rainfall erosivity (El ${ }_{30}$ ) over the (a) 2011 and (b) 2012 rainy seasons at the three experimental sites. $E_{30}$ was calculated with the KE-I relationship developed for Cabo Verde (Sanchez-Moreno et al., 2014). Arrows indicate erosive rainfall events (rainfall causing runoff).

\subsection{Results}

\subsubsection{Rainfall characteristics}

Total seasonal rainfall was 565, 481 and $549 \mathrm{~mm}$ in 2011 and 572, 519 and $540 \mathrm{~mm}$ in 2012 at sites I, II and III, respectively (Table 3.1). These values were substantially higher than the average precipitation for all three sites for August to October for 1980-2010. The total rainfall did not significantly differ among the sites for each year, but the distribution 
varied considerably (Figure 3.3). The 2011 rainy season began earlier (August 8) and continued until the end of October but with a dry period of 20 days in September that affected crop development. The first rain in 2012, however, fell in late August and continued well distributed throughout September with 12 days of rain, but no rain fell in October. Of the 16 rainy days in 2011, five were light $(<20 \mathrm{~mm})$, three were heavy rains (>50 mm) and eight were moderate $(20-50 \mathrm{~mm}$ ). Of the 18 rainy days in 2012, five were $<20 \mathrm{~mm}$, only one was $>50 \mathrm{~mm}$ and the others were $20-50 \mathrm{~mm}$ for all three sites (Figure 3.3).

In 2011, seasonal rainfall erosivity EI30 (in $\mathrm{KJ} \mathrm{m}^{-2} \mathrm{~mm} \mathrm{~h}^{-1}$ ) was 473, 378 and 457 for sites I, II and III, respectively, with the highest monthly value occurring in October and the lowest in September. The highest daily EI30 values (in $\mathrm{KJ} \mathrm{m}^{-2} \mathrm{~mm} \mathrm{~h}^{-1}$ ) were 90 and 85, corresponding to 87 and $83 \mathrm{~mm}$ rainfall, respectively, and occurred at sites I and III, both on September 02 (Figure 3.3). At site II, daily values were lower and the highest (59) occurred on October 25 . In 2012, seasonal erosivity values were slightly lower for sites I (417) and III (403) and similar for site II (377), while the highest monthly value occurred in September. The highest daily $\mathrm{El}_{30}$ values were 86, 74 and 56 for sites I, II and III, respectively, corresponding to 84,75 and $60 \mathrm{~mm}$ rainfall, occurring on September 24 at sites II and III and on September 30 at site I (Figure 3.3).

\subsubsection{Effect of treatments on runoff and soil loss}

\section{Total seasonal runoff}

All treatments generally produced significantly less seasonal runoff than the control, with T3 much better $(P<0.01)$ than all other treatments at all three sites in both years (Table 3.4A). T3 had the lowest seasonal runoff rate $\left(0.1 \mathrm{~L} \mathrm{~m}^{-2}\right)$ at site $\mathrm{I}$ in 2012 , and T0 had the highest rate $\left(20 \mathrm{~L} \mathrm{~m}^{-2}\right)$ at site II in 2012. Total runoff was significantly higher for all treatments and the control in 2012 than in 2011. Compared to T0, T3 reduced total runoff by $84 \%$ (site II) to $90 \%$ (site I) in 2011 and by $95 \%$ (site III) to 99\% (sites I and II) in 2012. Runoff generation for both years was in the order $\mathrm{T} 3<\mathrm{T} 1=\mathrm{T} 2<\mathrm{T} 0$ at site $\mathrm{I}$ and in the order $\mathrm{T} 3<\mathrm{T} 1=\mathrm{T} 2=\mathrm{T} 0$ at sites II and III. For slopes $>10 \%$ (sites II and III), only the mulch treatment (T3) significantly reduced runoff, and the soil surfactant combined with either manure or compost (T1/T2) significantly reduced runoff on the slope $<10 \%$ (site I). Runoff reduction followed the order $\mathrm{T} 3>\mathrm{T} 1 \geq \mathrm{T} 2$ for 2011 and $\mathrm{T} 3>\mathrm{T} 2>\mathrm{T} 1$ for 2012 at sites II and III and $\mathrm{T} 3>\mathrm{T} 2>\mathrm{T} 1$ for 2011 and $\mathrm{T} 3>\mathrm{T} 2>\mathrm{T} 1$ for 2012 at site I. These results confirm the high effectiveness of $\mathrm{T} 3$ at all sites. 
The runoff coefficients for the two years were low, varying from nearly negligible at site I in 2011 to $6.7 \%$ at site II in 2012 (Table 3.5A). T3 had the lowest proportion of seasonal rainfall lost as runoff, and T0 had the highest. T1 and T2 did not generally differ in either year at any of the sites. Even though 2012 had fewer events, T0, T1 and T2 had higher runoff coefficients in 2012 than 2011, except for T2 at site III.

Table 3.4(A) Total runoff (mean \pm standard deviation) and runoff reduction and (B) total soil loss (mean \pm standard deviation) and reduction in soil loss at each experimental site for the 2011 and 2012 rainy seasons as a function of treatment. Lowercase letters indicate significant differences (Dunnet T3 test) between the treatments at the same site $(P<0.05): a<b<c<d$. For detailed treatment descriptions, see Table 3.3. Site I did not include pigeon-pea hedges.

A

\begin{tabular}{|c|c|c|c|c|c|c|}
\hline \multirow[t]{2}{*}{ Treatment } & \multicolumn{2}{|c|}{1} & \multicolumn{2}{|c|}{ II } & \multicolumn{2}{|c|}{ III } \\
\hline & $\begin{array}{l}\text { Runoff } \\
\left(\mathrm{L} \mathrm{m}^{-2}\right)\end{array}$ & $\begin{array}{c}\% \\
\text { reduction } \\
\text { in runoff }\end{array}$ & $\begin{array}{l}\text { Runoff } \\
\left(\mathrm{L} \mathrm{m}^{-2}\right)\end{array}$ & $\begin{array}{c}\% \text { reduction } \\
\text { in runoff }\end{array}$ & $\begin{array}{l}\text { Runoff } \\
\left(\mathrm{L} \mathrm{m}^{-2}\right)\end{array}$ & $\begin{array}{c}\% \\
\text { reduction } \\
\text { in runoff }\end{array}$ \\
\hline \multicolumn{7}{|l|}{2011} \\
\hline TO & $6.17 \pm 2.16 c$ & 0 & $11.3 \pm 1.95 b$ & 0 & $15.0 \pm 0.41 b$ & 0 \\
\hline $\mathrm{T} 1$ & $2.98 \pm 2.50 \mathrm{~b}$ & 52 & $9.00 \pm 0.25 b$ & 20 & $12.6 \pm 1.05 b$ & 16 \\
\hline $\mathrm{T} 2$ & $2.65 \pm 1.39 b$ & 57 & $9.20 \pm 2.28 b$ & 19 & $13.2 \pm 2.15 b$ & 12 \\
\hline $\mathrm{T} 3$ & $0.70 \pm 0.33 a$ & 90 & $1.83 \pm 0.67 a$ & 84 & $6.65 \pm 3.48 a$ & 86 \\
\hline \multicolumn{7}{|l|}{2012} \\
\hline то & $12.1 \pm 1.76 c$ & 0 & $20.1 \pm 0.23 c$ & 0 & $16.4 \pm 1.64 \mathrm{~b}$ & 0 \\
\hline $\mathrm{T} 1$ & $6.81 \pm 1.08 b$ & 44 & $17.6 \pm 0.53 b c$ & 12 & $14.8 \pm 1.59 \mathrm{~b}$ & 10 \\
\hline $\mathrm{T} 2$ & $8.33 \pm 2.65 b$ & 31 & 15. $4 \pm 2.29 b$ & 23 & $11.3 \pm 4.25 b$ & 31 \\
\hline $\mathrm{T} 3$ & $0.11 \pm 0.19 a$ & 99 & $0.17 \pm 0.10 \mathrm{a}$ & 99 & $0.75 \pm 1.30 \mathrm{a}$ & 95 \\
\hline ANOVA & 0.000 & & 0.000 & & 0.000 & \\
\hline \multicolumn{7}{|c|}{ B } \\
\hline \multirow[t]{2}{*}{ Treatment } & \multicolumn{2}{|c|}{ 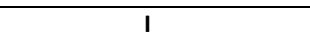 } & \multicolumn{2}{|c|}{ II } & \multicolumn{2}{|c|}{ III } \\
\hline & $\begin{array}{l}\text { Soil loss } \\
\left(\mathrm{g} \mathrm{m}^{-2}\right)^{*}\end{array}$ & $\begin{array}{c}\% \\
\text { reduction } \\
\text { in soil loss }\end{array}$ & $\begin{array}{c}\text { Soil loss } \\
\left(\mathrm{g} \mathrm{m}^{-2}\right)\end{array}$ & $\begin{array}{c}\% \\
\text { reduction } \\
\text { in soil loss }\end{array}$ & $\begin{array}{l}\text { Soil loss } \\
\left(\mathrm{g} \mathrm{m}^{-2}\right)\end{array}$ & $\begin{array}{c}\text { \% reduction } \\
\text { in soil loss }\end{array}$ \\
\hline \multicolumn{7}{|l|}{2011} \\
\hline T0 & $16.9 \pm 5.21 \mathrm{c}$ & 0 & $321 \pm 132 d$ & 0 & $1660 \pm 288 c$ & 0 \\
\hline T1 & $4.18 \pm 1.43 a$ & 75 & $91.7 \pm 12.3 \mathrm{~b}$ & 71 & $506 \pm 382 b$ & 70 \\
\hline $\mathrm{T} 2$ & $8.44 \pm 2.36 \mathrm{~b}$ & 50 & $128 \pm 28.6 \mathrm{c}$ & 60 & $661 \pm 366 b$ & 60 \\
\hline Т3 & $1.74 \pm 1.10 \mathrm{a}$ & 90 & $6.77 \pm 4.81 \mathrm{a}$ & 98 & $44.3 \pm 26.0 \mathrm{a}$ & 97 \\
\hline \multicolumn{7}{|l|}{2012} \\
\hline TO & $38.9 \pm 17.6 c$ & 0 & $104 \pm 18.4 c$ & 0 & $156 \pm 15.6 c$ & 0 \\
\hline $\mathrm{T} 1$ & $8.99 \pm 3.66 b$ & 77 & $35.2 \pm 16.4 b$ & 66 & $41.0 \pm 15.1 \mathrm{~b}$ & 74 \\
\hline $\mathrm{T} 2$ & $9.90 \pm 6.42 b$ & 75 & $48.1 \pm 18.4 \mathrm{~b}$ & 54 & $25.0 \pm 14.4 b$ & 84 \\
\hline $\mathrm{T} 3$ & $0.02 \pm 0.01 a$ & 100 & $0.05 \pm 0.04 a$ & 100 & $0.68 \pm 0.12 a$ & 100 \\
\hline $\begin{array}{l}\text { ANOVA } \\
(0.05)\end{array}$ & 0.005 & & 0.000 & & 0.000 & \\
\hline
\end{tabular}




\section{Total seasonal soil loss}

All treatments generally lost significantly $(P<0.05)$ less soil than the control. T3 had the lowest rate of soil loss at all three sites in both years (Table 3.4B). Site III had the highest rates of soil loss in 2011, reaching 16.6, 5.1, 6.6 and $0.4 \mathrm{Mg} \mathrm{ha}^{-1}$ for T0, T1, T2 and T3, respectively. The rates at site II were $3.2,0.9,1.3$ and $0.1 \mathrm{Mg} \mathrm{ha}^{-1}$ for the same treatments.

The rates were very low at site I; TO had the highest rate $\left(0.2 \mathrm{Mg} \mathrm{ha}^{-1}\right)$, and T1, T2 and T3 had negligible rates. These trends were similar in 2012, but the highest rate of soil loss was only $1.6 \mathrm{Mg} \mathrm{ha}^{-1}$ (TO). T1 did not generally differ significantly $(P>0.05)$ from $\mathrm{T} 2$, but both lost significantly $(P<0.05)$ less soil than T0. The mean rates of soil loss were $0.8,1.34$ and $7.2 \mathrm{Mg} \mathrm{ha}^{-1}$ in 2011 and $0.1,0.5$ and $0.6 \mathrm{Mg} \mathrm{ha}^{-1}$ in 2012 at sites I, II and III, respectively. The highest mean rates of soil loss for the two years were $0.3,2.1$ and $9.1 \mathrm{Mg}$ ha $^{-1}$ at sites I, II and III, respectively.

Table 3.5 (A) Runoff coefficients (\%) and (B) specific erosion rate ( $\mathrm{g} \mathrm{m}-2 \mathrm{~mm}$-1rain) for the treatments at sites I, II and III in 2011 and 2012. Seasonal erosive rainfall amounts ( $\mathrm{mm}$ ) were: Site I - 452; Site II - 386; Site III - 318 in 2011; and Site I - 296; Site II - 300; Site III - 292 in 2012. For treatment descriptions, see Table 3.3. Site I did not include pigeon-pea hedges.

\begin{tabular}{ccccccc}
\hline Treatment & \multicolumn{2}{c}{ Site I } & \multicolumn{3}{c}{ Site II } & \multicolumn{2}{c}{ Site III } \\
\cline { 2 - 7 } & $\mathbf{2 0 1 1}$ & $\mathbf{2 0 1 2}$ & $\mathbf{2 0 1 1}$ & $\mathbf{2 0 1 2}$ & $\mathbf{2 0 1 1}$ & $\mathbf{2 0 1 2}$ \\
\hline T0 & $1.4 \pm 0.5$ & $4.1 \pm 0.5$ & $2.9 \pm 0.5$ & $6.7 \pm 0.1$ & $4.7 \pm 0.1$ & $5.6 \pm 0.6$ \\
T1 & $0.7 \pm 0.6$ & $2.3 \pm 0.3$ & $2.3 \pm 0.1$ & $5.7 \pm 0.2$ & $4.0 \pm 0.3$ & $5.1 \pm 0.5$ \\
T2 & $0.6 \pm 0.3$ & $3.0 \pm 0.8$ & $2.4 \pm 0.6$ & $5.1 \pm 0.7$ & $4.3 \pm 0.7$ & $3.9 \pm 1.4$ \\
T3 & $0.2 \pm 0.1$ & $0 \pm 0.1$ & $0.5 \pm 0.2$ & $0.1 \pm 0.0$ & $2.1 \pm 1.1$ & $0.3 \pm 0.1$ \\
& & & & & & \\
T0 & $0.04 \pm 0.01$ & $0.13 \pm 0.06$ & $0.83 \pm 0.34$ & $0.35 \pm 0.06$ & $5.22 \pm 0.91$ & $0.53 \pm 0.05$ \\
T1 & $0.01 \pm 0.00$ & $0.03 \pm 0.01$ & $0.24 \pm 0.03$ & $0.12 \pm 0.05$ & $1.59 \pm 1.20$ & $0.14 \pm 0.05$ \\
T2 & $0.02 \pm 0.01$ & $0.03 \pm 0.02$ & $0.33 \pm 0.07$ & $0.16 \pm 0.06$ & $2.08 \pm 1.15$ & $0.09 \pm 0.05$ \\
T3 & $0.00 \pm 0.00$ & $0.00 \pm 0.00$ & $0.02 \pm 0.01$ & $0.00 \pm 0.00$ & $0.14 \pm 0.08$ & $0.00 \pm 0.00$ \\
\hline
\end{tabular}

All treatments had significantly less soil loss in 2011 compared to the control, but the effect varied among the sites in the orders $\mathrm{T} 3=\mathrm{T} 1<\mathrm{T} 2<\mathrm{T} 0$ at site $\mathrm{I}, \mathrm{T} 3<\mathrm{T} 1<\mathrm{T} 2<\mathrm{T} 0$ at site II and $\mathrm{T} 3<\mathrm{T} 1=\mathrm{T} 2<\mathrm{T} 0$ at site III. The order in 2012 was $\mathrm{T} 3<\mathrm{T} 1=\mathrm{T} 2<\mathrm{TO}$ for all sites. These results indicate that T3 was best at reducing soil loss. The effectiveness of the T2 at sites II and III increased from 2011 to 2012.

The reduction of soil loss due to the treatments was variable (Table 3.4B), with T2 producing the lowest reduction (54\%) at site II in 2012 and T3 the highest (100\%) at all sites, also in 2012. Soil loss was low in 2012, except at site II, but the magnitude of reduction was higher than in 2011 for all treatments. The order of reductions was $\mathrm{T} 3>\mathrm{T} 1>\mathrm{T} 2$, except T2 produced a larger reduction than T1 at site III in 2012. These results 

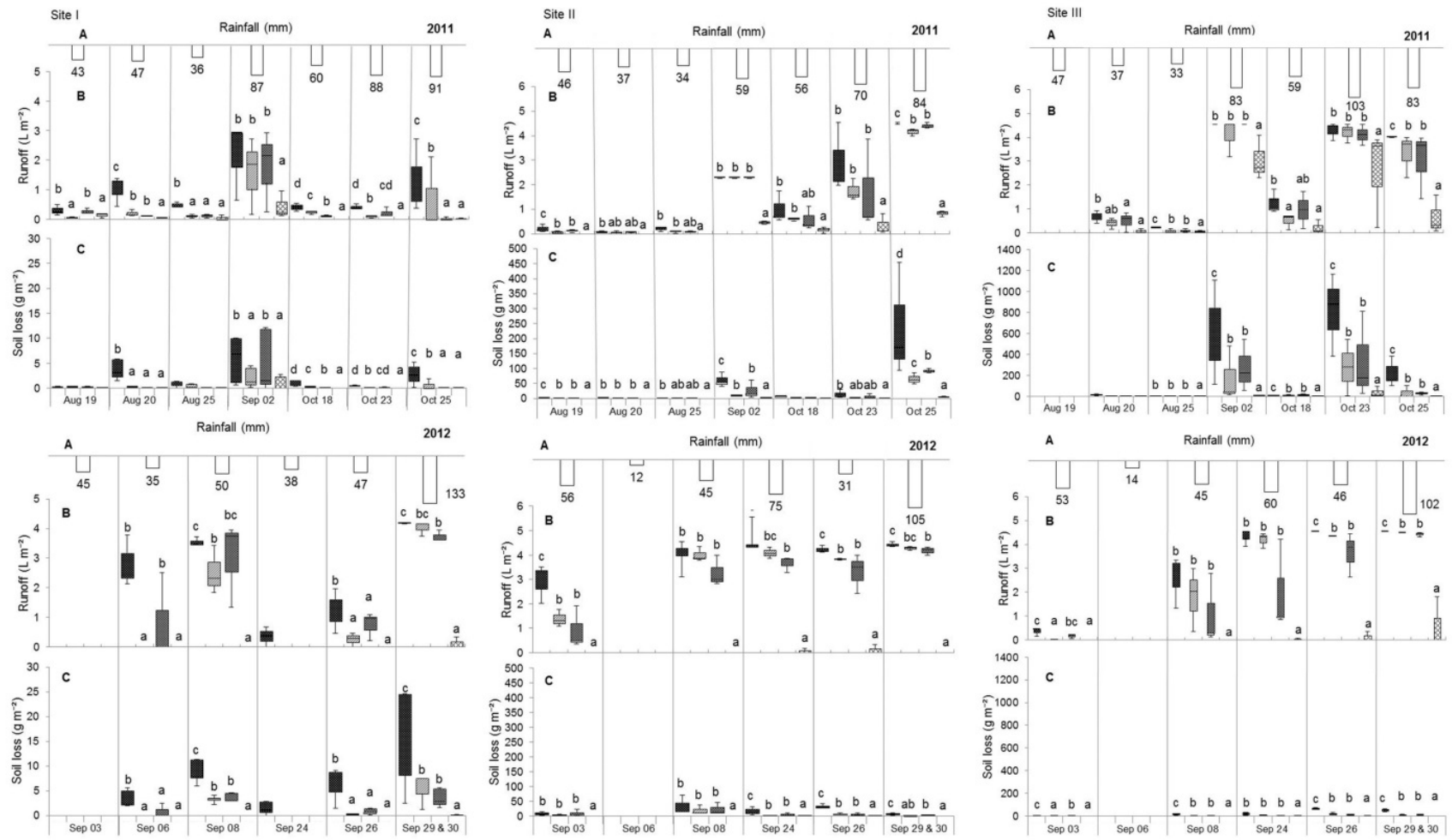

Figure 3.4 I-III. Treatment effects on runoff (B) and sediment (C) per erosive rainfall event (A) during the 2011 and 2012 rainy seasons at sites I, II and site III. For each date on the $x$-axis, treatments from left to right are TO, T1, T2 and T3. Lowercase letters indicate significant differences (Mann-Whitney Utest): $a<b<c<d$. For treatment descriptions, see Table 3.3. 
also confirm the high effectiveness of T3, which reduced soil loss between $90 \%$ (site I) and 98\% (site II) in 2011 and completely eliminated soil loss in 2012. Total soil loss was higher in 2011 than in 2012 at the sites with steeper slopes (II and III), but total runoff was higher. Both runoff and sediment yield were lowest in 2011 and highest in 2012 at the low-slope site (I), despite more rainfall events in 2011. All treatments resulted in more reduction in soil loss rates than in runoff rates at all sites, but T3 also resulted in high runoff reduction. The standard deviations from the means of seasonal runoff and sediment yield in the treatments were very high in both years (Table 3.4A and B), indicating the variable effects of the treatments.

The specific soil loss rates ( $\mathrm{g} \mathrm{m}^{-2} \mathrm{~mm}^{-1}$ rain) show negligible values for site I in both seasons, for all treatments and control, with T3 eliminating erosion completely (Table 3.5B). The highest values were obtained at site III in 2011 for T0 (5.22) T1 (1.59), T2 (2.08) and T3 (0.14). Except for site I, values for 2011 were higher than for 2012, for all treatments and sites, following the order T0>T2>T1>T3.

\section{Runoff and sediment yield per rainfall events}

Of the 16 rainy days during the 2011 growing season, seven produced runoff at sites I and II and six at site III from August 19 to October 25. Of the 18 rainy days in 2012, five produced runoff during September but not simultaneously at all sites; the rainfall on September 3 caused runoff at sites II and II but not at site I and the rainfall on September 6 caused runoff only at site I (Figure 3.3). The first three events for 2012 generated very little runoff and sediment at all sites, even though soil cover was low and the soil surface was still affected by disturbance from field work after the first rain.

The amount of runoff per event varied among the treatments and sites (Figure $3.4 \mathrm{I}-\mathrm{III}$ ). Rainfalls $<40 \mathrm{~mm}$ generally only produced runoff when the rain fell shortly (1-5 days) after an earlier rainfall and when the soil was still wet, reaching saturation with a small amount of rain. Runoff was generally low for all events in both years at site I with a low slope gradient (Figure 3.4-I), with the highest runoff generation (3-4 $\mathrm{L} \mathrm{m}^{-2}$ ) in the control plot for the heaviest events on September $2(87 \mathrm{~mm}$ ) in 2011 and on September 29 and 30 (133 $\mathrm{mm}$ ) in 2012. Runoff was generally low, but T3 had significantly less runoff than T0 for all events. Runoff from T1 and T2 was not consistently significantly different from T0. For events $<47 \mathrm{~mm}$ in the first year, all treatments contributed to less runoff generation than the control, while for events, the effects of T1 and T2 were similar to that of T0. Only five events caused significant runoff in 2012, in which T2 was similar to T0, while T1 and T3 had significantly $(P<0.05)$ less runoff than T0, suggesting positive effects for both manure combined with soil surfactant and mulch combined with compost. 
Erosion rates were low at site I for events $\leq 43 \mathrm{~mm}$ in 2011 and $\leq 35 \mathrm{~mm}$ in 2012 (Figure 3.4-I), and no significant effects of the treatments $(P>0.05)$ were observed. For heavier events, however, all treatments generated significantly $(P<0.05)$ less sediment compared to the control in both years. T1 and T2 did not differ significantly for most events in both years.

For the steepest slope (site II), the highest runoff rate in 2011 occurred over the last two heavy events ( $>70 \mathrm{~mm}$ ) even though soil cover was high for all treatments, while the most significant runoff in 2012 occurred over the last four events from September 8 to 29 (Figure 3.4-II). All treatments generally had a positive effect on runoff, with T3 generating significantly $(P<0.05)$ less runoff than all other treatments and the control over the two years. T1 and T2, however, did not differ significantly from T0 in 2011, except for the first and last events. In 2012, T2 and T3 generated less runoff than T0 for all events, and T1 was similar to TO for events $>75 \mathrm{~mm}$. Soil loss at this site followed a trend identical to that of runoff, with T3 producing the best results in both years. The magnitude of soil loss, however, was relatively low for all events and treatments.
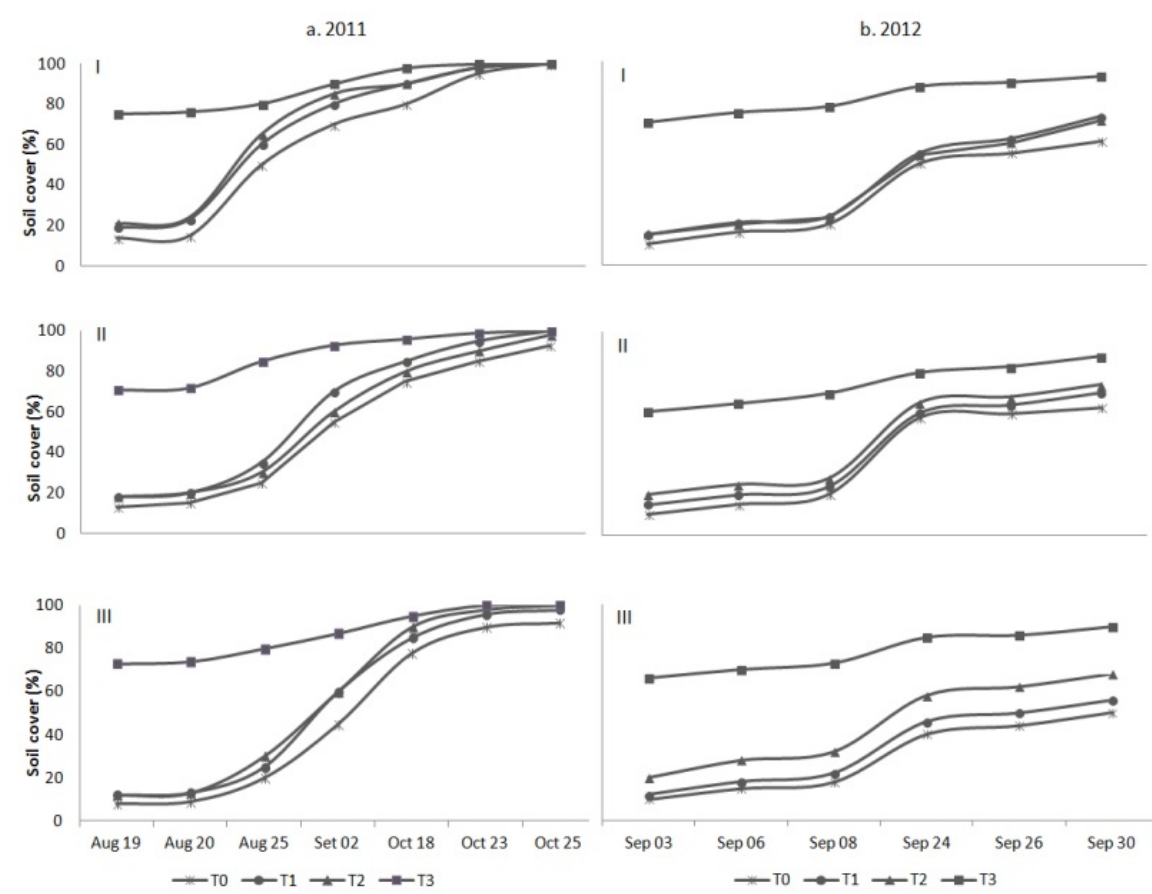

Figure 3.5 Estimated soil cover for daily erosive rainfall events at sites I (São Jorge), II (Serrado) and III (O. Pequenos) in the 2011(a) and 2012(b) seasons, as influenced by the treatments. Planting dates were: August 7-8 2011 and August 28-29 2012. For treatment descriptions, see Table 3.3. 
On the moderate slope (site III), all treatments produced significantly less runoff than the control for all events, with T3 again having the least runoff (Figure 3.4-III), while the effect of the other treatments depended on the event. High runoff rates, generating large amounts of sediment, occurred in 2011 for heavy events from September 2 to October 25. The $59 \mathrm{~mm}$ event on October 18, though, did not generate large amounts of runoff. T3 produced the least amount of runoff and sediment. In 2012, T3 still produced the lowest runoff and soil loss. For $45 \mathrm{~mm}$ (September 8 ) and $60 \mathrm{~mm}$ (September 24) events, runoff from T1 and T2 did not differ from T0. Despite the large variability among the events, and even though T1 and T2 may have contributed to reduce runoff and/or soil loss, T3 produced the best results, nearly eliminating runoff and soil loss at all sites in both years.

\subsubsection{Soil cover}

Soil cover was highest for T3 and lowest for T0 in both years and for all sites and events, with the general effect of the treatments in the order T3>T2>T1>T0 (Fig. 5). T1 and T2 were identical at site I in either year, but T2 had a larger effect than T1 at sites II and III, particularly in 2012. Soil cover varied for all treatments from as low as $8 \%$ (T0) at the beginning of the 2011 season to $100 \%$ at the end, and from $10 \%$ (T0, all sites) to $93 \%$ (T3, site III) in 2012, with none of the treatments reaching 100\%. Except for T3 that showed a constant trend in the two years, the other treatments and the control varied more throughout the seasons, but more so in 2011.

\subsubsection{Effect of treatments on soil-moisture content}

The effect of the treatments on soil moisture, inside and between the planting pits, differed among the sites in 2012 for the various rains (Figure 3.6). At site I, T3 had a significantly $(P<0.05)$ higher moisture content relative to T0 both inside and between the planting pits for the last rain $(133 \mathrm{~mm})$ and also inside the pits for the rain on September $26(47 \mathrm{~mm})$. T3, however, did not differ significantly $(P>0.05)$ from the other treatments. Moisture content at site II was higher in the treated plots than in the control for most of the rains, both inside and between pits, but the effects of the treatments were not statistically significant $(P>0.05)$ for any of the events. Moisture content at site III, however, was significantly higher for T2 and T3, particularly for the last three events (60, 46 and 102 $\mathrm{mm}$ ), both inside and between pits, while the contents were identical in T0 and T1.

Soil moisture was generally higher between than in the pits for all treatments, event and sites. Only T3 had consistently higher moisture contents between the pits, while the other 
A
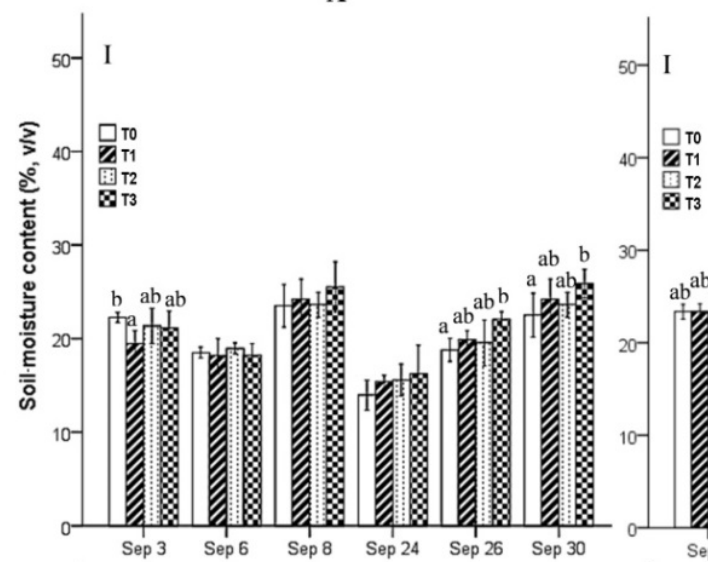

B
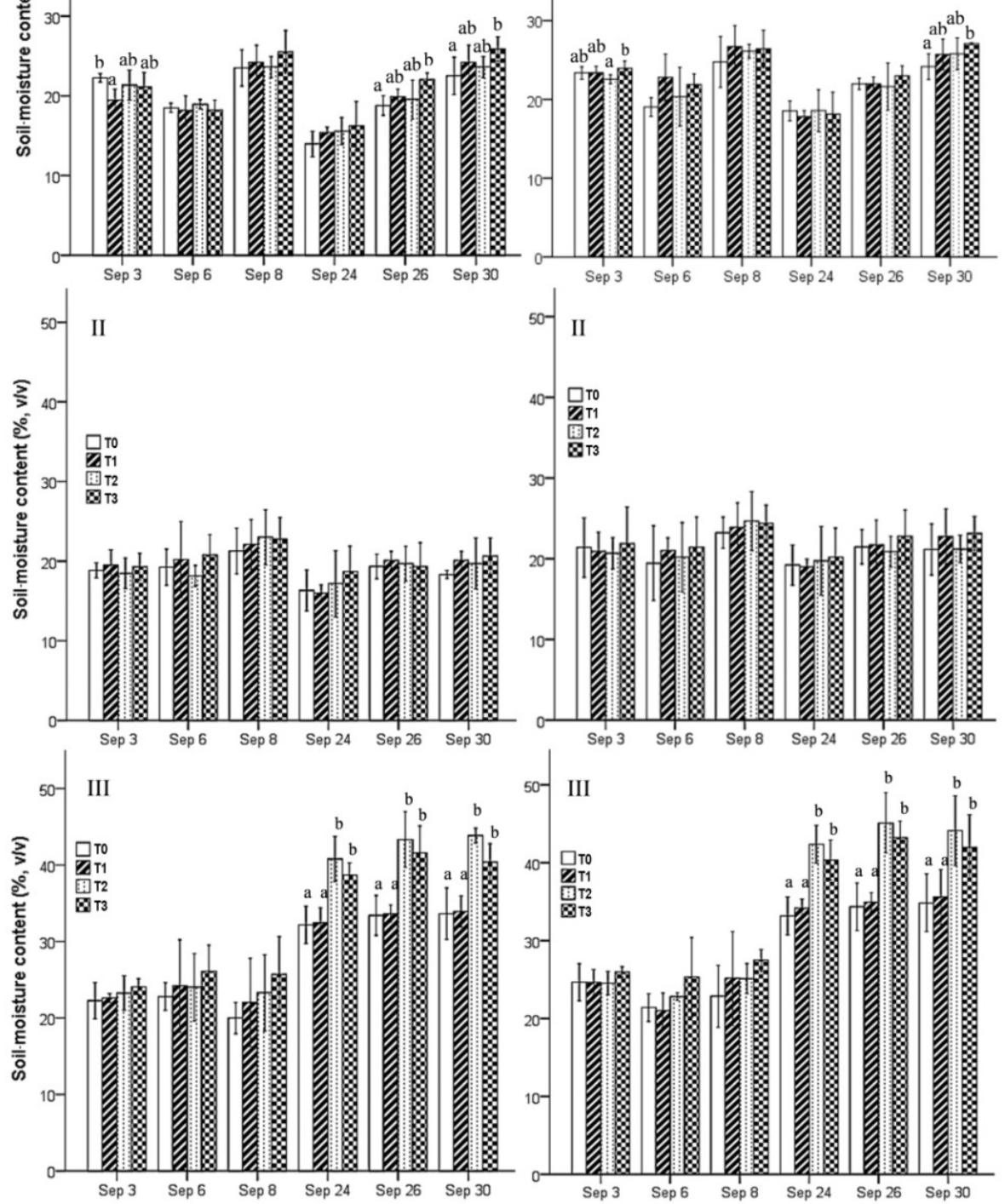

Figure 3.6 Soil-moisture contents at 15-cm depths (A) inside and (B) between the planting pits for the various treatments at sites I, II and III during the 2012 rains. Lowercase letters indicate significant differences: $a<b$. For treatment descriptions, see Table 3.3. 
treatments had significantly higher moisture contents mainly inside the pits. The mean seasonal soil-moisture contents at the sites followed the orders $I I \leq I \quad(20-21 \%)<I I(30 \%)$ inside the pits and II $\leq \mathrm{I}(22-23 \%)<I I I(32 \%)$ between the pits.

\subsubsection{Relationships between the various parameters}

\section{Runoff-erosion relationship}

In general, runoff and soil loss were reasonably well positively correlated $(\alpha=0.001)$ in both years at all sites, but the correlation was strongest in 2012. The order of correlation (Pearson) among the sites was II (0.756)>III (0.708)>I (0.595) in 2011 and I (0.800)>II $(0.790)>$ III (0.693) in 2012. However, soil loss did not linearly increase with increase in runoff for all treatments, at all sites. In 2011, for T0, the runoff-erosion relationship coefficient $\left(r^{2}\right)$ was significant $(p<0.05)$ only at site II $(0.804)$; for T1, at sites I $(0.981)$ and II (0.998); for T2, only at site II (0.969); and for T3, at all sites ( $\geq 0.924)$. In 2012, except for T3 that had significant $r^{2}$ values at all sites (1.000), T0-T2 only had significant values at site III (0.996, 0.996 and 0.934, for T0, T1 and T2, respectively).
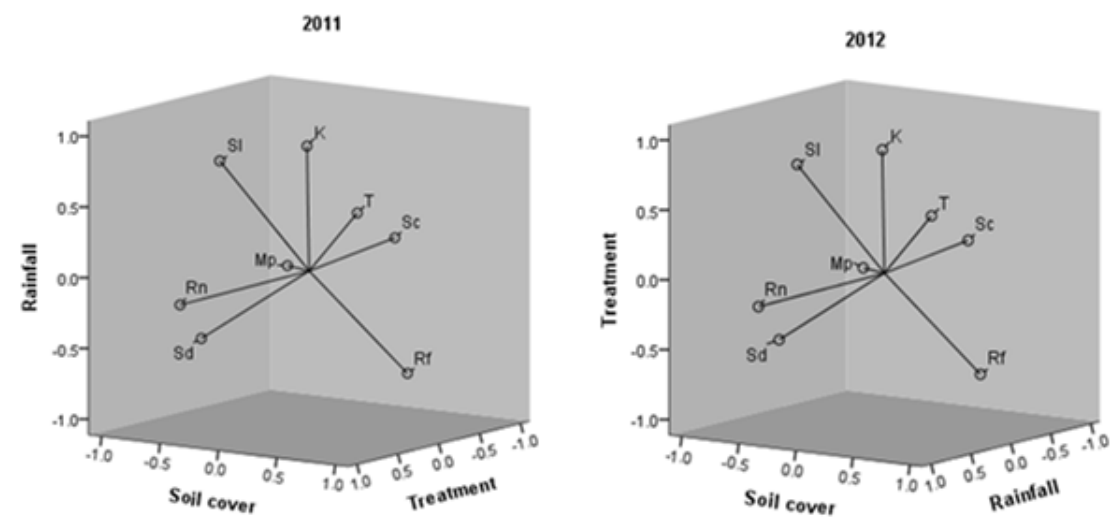

Figure 3.7 PCA plots for the 2011 and 2012 rainy seasons showing the three PCs extracted in both years. $T$, treatment; Rf, rainfall; Rn, runoff; Sd, sediment; Sl, slope; $M p$, soil moisture in pits; Sc, soil cover; $K$, initial infiltration rate.

\section{Factors influencing runoff and soil loss}

The three principal components (PCs) extracted explained 91 and $87 \%$ of the variance in the data in 2011 and 2012, respectively. The main components in 2011 were: soil cover $(42 \%)$, treatment (19\%) and rainfall (30\%). PC1 (soil cover) explained $49 \%$ the variance in 2012, with treatment and rainfall mainly related to PC2 and PC3, respectively (Figure 3.7). Runoff and soil loss were positively correlated with slope and rainfall but negatively correlated with soil cover and initial soil-infiltration rate in both years. Rainfall, however, 
was more strongly correlated with soil loss, and slope was more strongly correlated with runoff (Table 3.6). Runoff was high on the steepest landscape (site II), but sediment yield was lower than at site III, which had a lower slope.

In 2011, parameters such as runoff, sediment, treatment and soil cover were more strongly associated with PC1; rainfall, slope and infiltration were more strongly associated with PC2 and soil moisture was mostly correlated with PC3 (Table 3.6). In 2012, however, rainfall and infiltration rate were strongly associated with $\mathrm{PC} 3$, slope was associated with PC2 and all other parameters were more strongly associated with PC1.

Table 3.6 PC matrix for the 2011 and 2012 experimental seasons showing the relationships between various parameters and the main components.

\begin{tabular}{|c|c|c|c|c|c|c|}
\hline \multirow[t]{2}{*}{ Parameter } & \multicolumn{3}{|c|}{ PCs 2011} & \multicolumn{3}{|c|}{ PCs 2012} \\
\hline & 1 & 2 & 3 & 1 & 2 & 3 \\
\hline Treatment & 0.67 & 0.53 & 0.36 & 0.87 & 0.37 & -0.08 \\
\hline Runoff & -0.83 & -0.27 & 0.39 & -0.93 & 0.37 & 0.04 \\
\hline Soil loss & -0.57 & -0.46 & 0.50 & -0.84 & 0.01 & -0.28 \\
\hline Rainfall & 0.67 & -0.69 & -0.24 & 0.33 & -0.57 & 0.72 \\
\hline Soil moisture in pits & 0.39 & 0.20 & 0.83 & 0.73 & 0.10 & -0.24 \\
\hline Soil cover & 0.85 & 0.35 & 0.17 & 0.89 & 0.37 & -0.05 \\
\hline Slope & -0.66 & 0.74 & 0.16 & -0.38 & 0.92 & 0.016 \\
\hline Infiltration rate & -0.35 & 0.78 & -0.47 & -0.20 & 0.69 & 0.69 \\
\hline
\end{tabular}

\subsection{Discussion}

\subsubsection{Effect of treatments on runoff and soil loss}

\section{Runoff}

The results indicate that runoff and soil loss are not generated for rainfall $<50 \mathrm{~mm}$ and soil moisture $\leq 20 \%$ for low-slope areas with medium-textured soils. Runoff can be expected for rainfall $>40 \mathrm{~mm}$, regardless of soil-moisture content, for coarse-textured soil on steep slopes. This confirms the results of Smolikowski et al. (2001) who reported runoff in Cabo Verde Regosols ( $>50 \%$ slope) only for rainfall $>40 \mathrm{~mm}$ and intensity $\left(\mathrm{I}_{30}\right)>$ than $40 \mathrm{~mm} \mathrm{~h}^{-1}$. For finer-textured soil (silt-clay-loam) on moderate slopes ( $\geq 23 \%)$, runoff will likely occur for rainfall $>60 \mathrm{~mm}$ and soil moisture $\geq 30 \%$.

All rainfall events in 2012 occurred in September, so the soil remained moist during this period; increasing the amount of rainfall did not change soil-moisture contents to any great extent. The increase in soil moisture accompanying the application of mulch, pigeonpea hedges and organic amendments at sites I and III corroborated the numerous studies 
(Montenegro et al., 2013; Ramakrishma et al., 2006; Ling-duo et al., 2013) that have reported the positive effect of mulch and compost on soil-moisture content. The lower soil-moisture contents inside than between the planting pits may have been due to the use of water by the plants.

Runoff occurs when rain intensity exceeds the infiltration capacity of the soil, which measures the ability of the soil to absorb and transmit water (Lal, 1975; Le Bissonnais et al., 2005; Schwab et al., 1993). Runoff occurs more commonly in arid and semi-arid regions, where rain intensities (or erosivity) are high and soil infiltration is impeded by surface crusting, dryness or rock fragments (Cerdà, 1996, 2001). The generation of runoff is an important factor in soil loss (Le Bissonnais et al., 2005) and has a strong relationship with the incidence of erosion. The fact that, on silty-clay-loam soil with slopes up to $23 \%$, and on the sandy loam up to $37 \%$, only the treatment combining mulch with pigeon-pea hedges and an organic amendment had a significant effect in runoff reduction highlights the high efficacy of the mulch in preventing runoff. This is because runoff is reduced by pigeon-pea, splash effect reduced by mulch and the infiltration capacity of the soils increased by mulch.

Residue mulch, as a system that maintains a protective cover of vegetation on the soil surface, has been widely used to reduce runoff and erosion from agricultural fields. The beneficial effects of mulching include protection of the soil against rain impact, decrease in runoff velocity and improved infiltration capacity of the soil (Zougmoré et al., 2003). Protecting the soil surface with a dead or living cover is an effective way to control erosion (Lal, 1975; Mando 1997; Novara et al., 2013).

Several authors (Cogle et al., 2002; Srinivasarao et al., 2014; Zougmoré et al., 2003) have reported the positive effect of organic amendments (i.e.compost and animal or green manure) on the reduction of runoff and soil loss in semi-arid areas. Zougmoré et al. (2003) reported $87 \%$ reduction in runoff and $75 \%$ reduction in soil loss with compost application in Bukina Faso. These organic amendments contribute to the integrity of soil particles, increasing aggregate stability and decreasing erosion rates.

Soil surfactants are designed to improve infiltration, distribution and retention of water (Mobs et al., 2012), runoff and water-use efficiency (Cooley et al, 2009; Lentz, 2003); thus the already high infiltration rate of the soils could explain the lack of response from the soil surfactant on runoff, obtained in the study on the sandy- and silt-clay loam soils. In addition, as those soils are on steep slopes, thus subject to runoff, under these conditions, a single application may not be enough. 
In this study, the pigeon-pea hedges without mulch at sites II and III were not effective in reducing runoff in the first year, and the effectiveness of the combination of mulch and hedges was mostly due to the mulch. Pigeon pea, as a perennial crop, does not develop a full canopy that can reduce the effect of raindrops on runoff during the first year. In 2012, however, the pigeon-pea plants developed a full canopy and deeper roots, and the hedges were better able to keep the soil in place, decreasing runoff 11 and $21 \%$ at sites II and III, respectively, compared to the plots without hedges. Smolikowski et al. (2001) reported $35 \%$ reduction in surface runoff with hedges of L. Leucocephala alone, comparatively to traditional maize and beans without hedges, on similar conditions.

The low runoff coefficients for all treatments (0.1-5.7\%) and the control (1.4-6.7\%) demonstrated the high permeability and infiltration potential of the soils regardless of treatment. They can also be due to the relatively low erosivity values registered for daily rainfalls during the two seasons when compared to extreme values $\left(\mathrm{El}_{30}\right.$ of $200-300 \mathrm{KJ} \mathrm{m}^{2}$ $\mathrm{mm} \mathrm{h}^{-1}$ ) reported by Sanchez-Moreno, 2014a). These results are comparable to the $5 \%$ reported by Smolikowski et al. (2001) on steeper slopes (50\%) even though the runoff coefficient for individual storms reached $49 \%$. However, they are lower than those reported by other authors (Botha et al., 2003; Hensley et al., 2000) stating that runoff can represent between 8 and $49 \%$ of the annual rainfall in semi-arid areas with fine-textured soils, depending on the prevailing conditions.

The higher runoff coefficients in $\mathbf{2 0 1 2}$ may be attributed to the concentration of rainfall in a shorter period, more aggressive (high erosivity) rainfall events and constantly wet soils. After a long dry period from September 2 to October 18 in 2011, a heavy rainfall of $59 \mathrm{~mm}$ did not generate large amounts of runoff, because the dry soil absorbed the water and rainfall erosivity was low.

\section{Soil loss}

Soil loss reached 16.6, 5.1, 6.6 and $0.4 \mathrm{Mg} \mathrm{ha}^{-1}$ on the silty-clay-loam soil (site III) for the control, surfactant, pigeon-pea and mulch/pigeon-pea (with organic amendment) treatments, respectively; 3.2, 0.9, 1.3 and $0.1 \mathrm{Mg} \mathrm{ha}^{-1}$ on the sandy loam soil (site II) and $<0.2 \mathrm{Mg} \mathrm{ha}^{-1}$ for all treatments and control on the loamy soil (site I). These results indicate that, at all sites, the traditional farming system lost more soil than the soil and water conservation treatments tested, but the magnitude of soil loss only exceeded the tolerable threshold values at sites II and III, in the 2011 rainy season.

The mean erosion rate from 1994 to 1996 found by Smolikowski et al. (2001) for traditional farming plots was $16 \mathrm{Mg} \mathrm{ha}^{-1} \mathrm{y}^{-1}$ under similar agropedological conditions but on a steeper (50\%) slope. The results obtained in our study in 2011and those obtained by 
Querido (1999) and Smolikowski et al. (2001) confirmed that soil erosion on Cabo Verde semi-arid, steep hillsides under current traditional rain-fed farming can be excessive.

Despite the steeper slopes and possibly more aggressive rains as suggested by the $\mathrm{El}_{30}$ values, the mean erosion rates in this study, particularly for sites I and II, are lower than those in other semi-arid Sahelian countries. Roose (1997) reported mean annual soil losses of $0.2-20 \mathrm{Mg} \mathrm{ha}^{-1}$ under different crops growing on glacis with less than a $3 \%$ slope in Burkina Faso, and Martin (1995) measured a mean annual soil loss of $9 \mathrm{Mg} \mathrm{ha}^{-1}$ on cultivated land in Niger, with maximum losses reaching $18.5 \mathrm{Mg}$ ha- $1 \mathrm{y}^{-1}$. In Nigeria, Ande et al. (2009) reported rates of 12.8 and $9.4 \mathrm{Mg} \mathrm{ha}^{-1}$, respectively, for rocky hill with $>15 \%$ slope and for low land. Most of these studies consider the tolerable threshold value of 12 $\mathrm{Mg} \mathrm{ha}^{-1}$ (Lal, 1998). However, given the shallow soils and the aggressive character of the rains in Cabo Verde (Sanchez-Moreno et al., 2013), the acceptable threshold rate should be substantially lower to ensure long-term production sustainability.

On the loamy soil ( $<10 \%$ slope), soil loss was not significant as the rates were below the acceptable threshold value of $3.6 \mathrm{Mg} \mathrm{ha}^{-1}$ for moderately deep soils (FAO, 1993), even for the traditional farming system (control). On the sandy loam, the highest soil loss rate for the control was slightly higher than the acceptable erosion threshold of $<3.0 \mathrm{Mg} \mathrm{ha}{ }^{-1} \mathrm{y}^{-1}$ for shallow soils, following the FAO criteria based on soil depth (FAO, 1993), with all treatments lowering soil loss below the threshold value. On the silty-clay-loam, even though all treatments strongly reduced soil loss, only the treatment combining mulch with pigeon-pea and an organic amendment was able to effectively prevent soil loss, lowering the rates below the acceptable threshold of $3.0 \mathrm{Mg} \mathrm{ha}^{-1}$, as it nearly eliminated soil loss.

Tavares and Amiotte-Suchet (2007) reported that areas of rain-fed farming on Santiago were at severe risk of water erosion, with $90-95 \%$ of the dryland area at high to very high risk. Sanchez-Moreno et al. (2014b) also reported soil losses of $43 \mathrm{Mg}$ ha'1 for extreme rain event in the watershed. For a more sustainable rain-fed farming system, the susceptibility to runoff and erosion should thus be reduced by applying conservation techniques of land management such as mulch combined with an organic amendment, with or without pigeon-pea hedges. The additional advantage of pigeon-pea (for increasing soil conservation, soil fertility and the production of biomass and food) can be an incentive to farmers. Pigeon-pea, as a perennial crop with roots deeper than those of maize and beans, can continue to produce biomass and to provide soil cover after the maize and beans have been harvested. 


\subsubsection{Relationships between the parameters}

Soil loss increased with increasing runoff, but at different magnitude at each site for the different treatments, indicating that, despite runoff being the major cause of soil loss, other factors were also involved. The higher rates of soil loss recorded at site III in 2011 than in 2012, despite identical runoff rates, confirm that runoff rate was not solely responsible for soil loss as also showed by the high specific soil loss rate $\left(\mathrm{g} \mathrm{m}^{-2} \mathrm{~mm}^{-1}\right.$ rain) and the variable runoff-erosion relationship coefficient (see 3.5). Mudflow and rill erosion were observed for the highly erosive daily rainfalls of September $2(83 \mathrm{~mm})$ and October $23(103 \mathrm{~mm})$ that transported large amounts of sediment and deposited them at the bottom of the slope, particularly for the control. Rills and mass transport may thus contribute substantially to the high erosion rate in this type of soil with a high content of silt and clay that swells as the water enters the soil, increasing its weight on the slope.

The pigeon-pea hedges (T2) were more effective in reducing soil loss rates than runoff rates. The high effectiveness of the treatment combining mulch with pigeon-pea hedges in reducing both erosion and runoff rates in the traditional system to negligible levels is likely due to the protection of the mulch and vegetation, controlling splash, runoff, rills and mass flow, as also reported by Ali et al. (2007) and Mingguo et al. (2007). Thus, the combination does not only reduce runoff volume, but also change the runoff-erosion relationship.

Several interrelated factors, namely amount, erosivity and frequency of rainfall (which affect moisture levels and time to saturation), degree of soil cover, slope and soil properties such as texture and infiltration rate influenced the runoff and soil loss during the study period, but soil cover was the main factor followed by rainfall and the treatments (see 3.5). The positive influence of soil cover on both runoff and soil loss indicate the importance of maintaining some residue on the soil surface during erosive rainfall events, as also reported by Cerdà (2001), Hartanto et al. (2003) and Kairis et al. (2013). The mulch provided a high degree of soil cover, which limits runoff by providing a physical barrier and protecting the soil surface from the erosive energy of rainfall. As the surface cover was high towards the end of the experimental seasons, the differences in runoff between the treatments and the control were less accentuated.

The rates of runoff were more influenced by the site slope and the rates of soil loss were more strongly influenced by the amount and erosivity of rainfall, partially explaining the highest runoff rates observed at the steepest landscape, but highest soil loss rate for a less steep landscape. Even though slope is assumed to have a positive relationship with soil loss (Wischmeier and Smith, 1965), this study found a decline in soil loss for the steepest 
slope, a finding also reported by Defersha et al. (2011) in Ethiopia highlands. Effect of slope on runoff and soil loss also depended on soil type and antecedent moisture.

\subsubsection{A promising SLM technique for the control of erosion and runoff for Cabo Verde dryland hillsides and its adoption by farmers}

The results show that a combination of an organic amendment with residue mulch and pigeon-pea hedges is very effective in controlling runoff and soil loss on the hillsides cultivated with dryland crops. Despite the benefits of this new technique for soil and environmental conservation, its adoption may not be easy or rapid due to economic reasons and the limited availability of organic amendments and plant material for mulching, particularly during drier years. Smaller amounts of residue mulch should thus be tested. Efforts to develop sustainable agricultural systems acceptable to the local population must be continued. Evaluations of the cost-effectiveness of these techniques, the yield benefits and the nutrient losses through runoff and erosion would be important for establishing the most sustainable options for the farmers under these semi-arid conditions.

The techniques tested in these experiments were selected with the participation of local stakeholders, and farmers were involved in the field trials. This level of participation could facilitate the adoption of the technique. Farmers could be motivated to adopt the new SLM technique by hosting demonstration plots, interacting with each other and being educated about the need to protect the soil. A participatory approach such as the farmerled technology-transfer model for transferring technologies for the management of natural resources, that gives farmers a central role in the process, could promote adoption.

\subsection{Conclusions and recommendations}

The erosive character of rainfall in Cabo Verde associated with the traditional practice of rain-fed farming can cause considerable losses of soil and water from agricultural fields, leading to soil degradation. The soils of the experimental sites had relatively high capacities for water retention and low runoff rates, but their continuous cultivation without protection will eventually accelerate the degradation of the land. Erosion was highly positively correlated with runoff. 
With this study, we conclude that a combination of mulch, pigeon-pea hedges and an organic amendment on steep slopes can significantly reduce runoff and erosion from dryland agricultural fields in Cabo Verde, thus contributing to a more efficient use of rainwater at the field level. Mulch or a soil surfactant combined with an organic amendment can also improve the use of rainwater on gentle slopes with low erodibility.

A shortcoming of the implementation of this combined technique, which includes some components of conservation farming, could be the lack of crop residue for use as mulch. This constraint, however, could be overcome by including a cover crop in the system to use as mulch. In addition, the pigeon-pea used as hedges could be pruned and also used as mulch. If the steep hillsides must be used for cultivating traditional crops such as maize and beans, and because land degradation must be stopped, then the agronomic practice of mulching combined with an organic amendment should be advocated to conserve soil and water. Pigeon-pea, either as hedges or intercropped with the maize and bean crops, should also be endorsed as a more permanent soil cover.

Given the variability of rainfall distribution between the two years of study and the limited erosion and runoff data at the plot level, there is a need to conduct experiments for longer periods to consolidate data, establish trends and standardize tolerable threshold erosion rates for the semi-arid steep hillsides.

Effective farmer involvement through demonstration plots, farmer interactions and education about the need to protect the soil will be crucial for the successful implementation of such techniques. For the Cabo Verde semi-arid hillsides, is recommended that sustainable land management techniques that increase rainwater-use and prevent further degradation of the natural resources be advocated and implemented. 


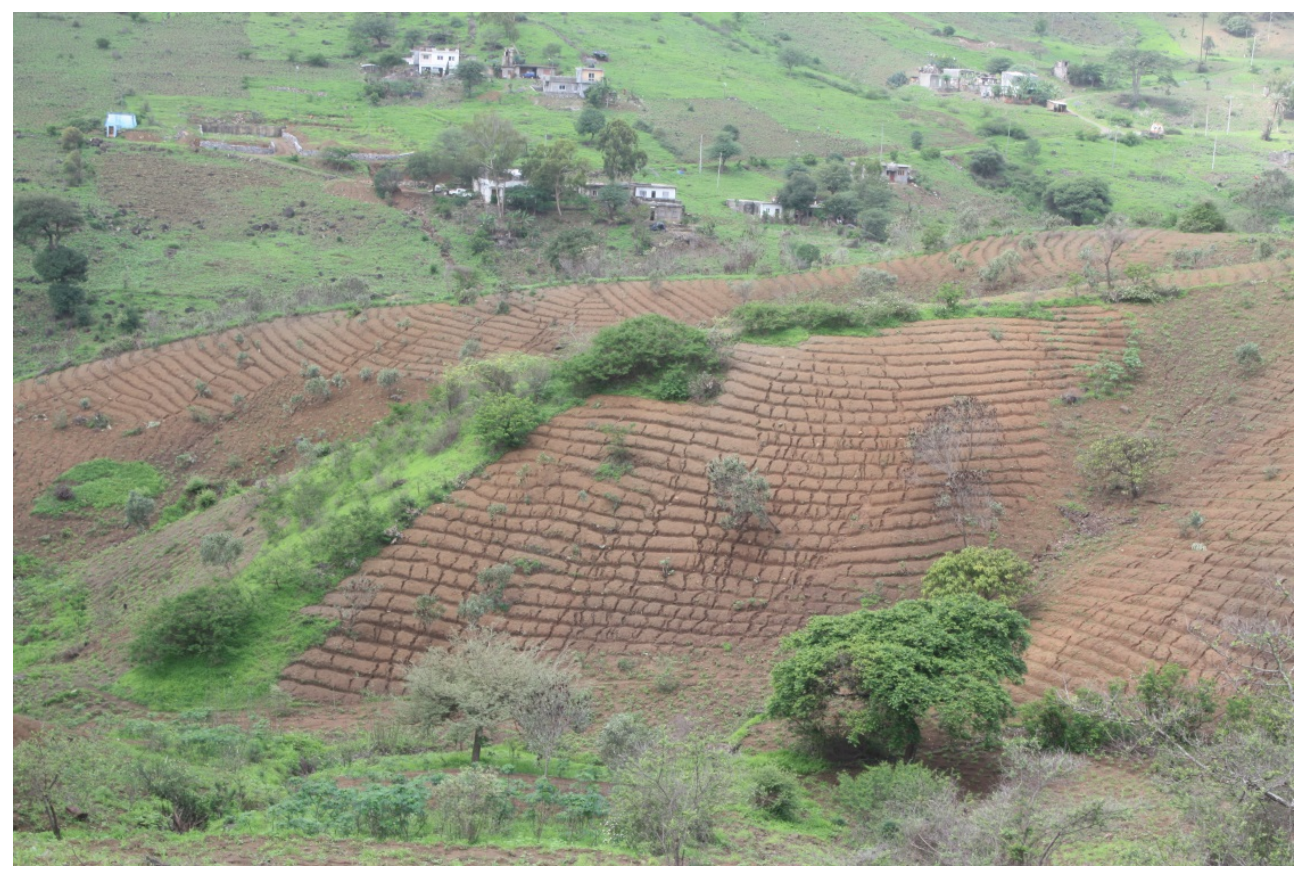




\section{Effect of integrated water-nutrient management strategies on soil erosion mediated nutrient loss and crop productivity in Cabo Verde drylands}

Soil erosion, runoff and related nutrient losses are a big risk for soil fertility in Cabo Verde drylands. In 2012, field trials were conducted in two agro-ecological zones to evaluate the effects of selected techniques of soil-water management combined with organic amendments (T1: compost/manure + soil surfactant; T2: compost/animal or green manure + pigeon-pea hedges + soil surfactant; T3: compost/animal or green manure + mulch + pigeon-pea hedges) on nitrogen $(N)$ and phosphorus $(P)$ losses in eroded soil and runoff and on crop yields. Three treatments and one control (traditional practice) were tested in field plots at three sites with a local maize variety and two types of beans. Runoff and eroded soil were collected after each erosive rain, quantified, and analysed for $\mathrm{NO}_{3}-\mathrm{N}$ and $\mathrm{PO}_{4}-\mathrm{P}$ concentrations. In all treatments runoff had higher concentrations of $\mathrm{NO}_{3}-\mathrm{N}$ (2.20$\left.4.83 \mathrm{mg} \mathrm{L}^{-1}\right)$ than of $\mathrm{PO}_{4}-\mathrm{P}\left(0.02-0.07 \mathrm{mg} \mathrm{L}^{-1}\right)$, and the eroded soil had higher content of $\mathrm{PO}_{4}-\mathrm{P}$ (5.27-18.8 $\left.\mathrm{mg} \mathrm{g}^{-1}\right)$ than of $\mathrm{NO}_{3}-\mathrm{N}\left(1.30-8.51 \mathrm{mg} \mathrm{g}^{-1}\right)$. The control had significantly higher losses of both $\mathrm{NO}_{3}-\mathrm{N}\left(5.4,4.4\right.$ and $\left.19 \mathrm{~kg} \mathrm{ha}^{-1}\right)$ and $\mathrm{PO}_{4}-\mathrm{P}\left(0.2,0.1\right.$ and $\left.0.4 \mathrm{~kg} \mathrm{ha}^{-1}\right)$ than the other treatments. T3 reduced soil loss, runoff and nutrient losses to nearly a $100 \%$ while $\mathrm{T} 1$ and $\mathrm{T} 2$ reduced those losses from 43 to $88 \%$. The losses of $\mathrm{NO}_{3}-\mathrm{N}$ and $\mathrm{PO}_{4}-\mathrm{P}$ were highly correlated with the amounts of runoff and eroded soil. Nutrient losses from the applied amendments were low (5.7\% maximum), but the losses in the control could indicate long-term nutrient depletion in the soil (19 and $0.4 \mathrm{~kg} \mathrm{ha}^{-1}$ of $\mathrm{NO}_{3}-\mathrm{N}$ and $\mathrm{PO}_{4}-\mathrm{P}$, respectively). T1-T3 did not consistently increase crop yield or biomass in all three sites, but T1 increased both crop yield and biomass. T3 (combining crop-residue mulch with organic amendment and runoff hedges) is the best treatment for steep slope areas but, the pigeonpea hedges need to be managed for higher maize yield. T1 (combining organic amendment with soil surfactant) could be a better choice for flatter areas with deeper soils.

This chapter is published as:

Baptista, I., Ritsema, C.J., Geissen, V. 2015. Effect of integrated water-nutrient management strategies on soil erosion mediated nutrient loss and crop productivity in Cabo Verde drylands. PLOS ONE 10 (7): e0134244. 


\subsection{Introduction}

A combination of nutrient depletion, mismanagement of fragile ecosystems, and harsh climatic conditions can lead to soil degradation in arid and semi-arid regions, particularly in the Sahel region, that threatens the sustainability of dryland agricultural systems (Smolikowski et al. 2001; Zougmoré et al., 2009; Bossio et al., 2010; Schwilch et al., 2012; Abdi et al., 2013; Reed et al. 2015). Soil erosion, nutrient depletion, and other forms of land degradation reduce crop productivity per unit of water (Rockström et al., 2009; Stroosnijder et al., 2012) and affect water availability, quality, and storage. Water erosion and recurrent droughts, both important drivers of land degradation, limit crop productivity. Increasing water infiltration and storage in the soil is the key for increasing soil productivity in sub-Saharan Africa (Lal, 2009).

Erosion by water is the most common form of land degradation worldwide and usually increases with agricultural activity, particularly with annual cropping systems where the soil surface is seasonally exposed to rain with high intensities (Bossio et al., 2010; Tavares et al. 2013). Erosion removes nutrients, thins the soil layer, reduces rooting depth, damages soil structure, and reduces infiltration, resulting in negative nutrient balances and lower crop yields in most farming systems in West Africa (Lal, 1998; Zougmoré et al., 2009; Bossio et al., 2010; Zougmoré et al., 2014) and parts of Asia (Zhao et al., 2013; Huang et al., 2015).

Rainfed (or dryland) agriculture plays, and will continue to play, a dominant role in providing food and livelihoods for an increasing global population (Rockström et al., 2010; Reed et al., 2015). Dryland agriculture produces most of the food consumed by poor communities in developing countries, with over $80 \%$ of the farmed land consisting of smallholder farms (Rockström et al., 2003; Cooper et al., 2012). Water-use efficiency, however, tends to be low (Bossio et al, 2010; Rockström et al., 2010). The productivity of dryland crops is particularly low in parts of sub-Saharan Africa and southern Asia, resulting in food insecurity and high levels of poverty in rural communities (Drechsel et al., 2003; Stroosnijder et al., 2012). The depletion of nutrients from rainfed agricultural soils in many Asian, African, and Latin American countries is so high that current agricultural land use is not sustainable (Bossio et al., 2010) and is considered the main biophysical factor limiting production on small-scale African farms (Drechsel et al., 2003; Zhao et al., 2013; Zougmoré et al., 2014). The loss of nutrients and organic matter needed for plant growth are associated with surface erosion, because they are concentrated in the surface layer and are thus subject to loss with the eroded soil (Ali et al., 2007; Zougmoré et al., 2009). Nutrient-use efficiency in cereal-based farming systems is also often very low due to shortages of moisture that limit the availability of nutrients (Buerkt et al., 2002; Zougmoré 
et al., 2009), particularly in the Sahel region, where nutrient limitation is a major cause of the per capita decline in crop production (Zougmoré et al., 2004).

Reversing land degradation is essential to improve water productivity, nutrient availability, and rural livelihoods in low-yielding dryland farming systems (Bossio et al., 2010; Schwilch et al., 2012). Many measures of soil and water conservation (SWC), such as terraces, check dams, contour stone walls, contour ridges, afforestation, hedges, tillage, mulching, soil amendments, and water harvesting, have been widely used to improve soil quality, decrease erosion and nutrient losses, and increase infiltration and crop productivity (Stroosnijder, 2003; Araya \& Stroosnijder, 2010; Araya et al., 2014).

Other factors that hinder crop productivity, however, must be simultaneously addressed to make use of the water gained from the mitigation of erosion-induced loss (Stroosnijder et al., 2012). Nutrients and moisture are the primary factors limiting crop growth and productivity in sub-Saharan Africa (Stroosnijder, 1996; Bationo et al., 1998; Bossio et al., 2010), so maximising the use of rainwater without addressing nutrient deficiency is pointless. The development and adoption of sustainable systems of land management able to replenish or maintain soil nutrients and to control runoff and soil loss are thus crucial. The simultaneous improvement of soil fertility and water conservation promotes water-nutrient synergy (Zougmoré et al., 2003; Stroosnijder et al., 2012), and covering the soil with crop residues helps to reduce runoff (Araya et al., 2011; Adimassu et al., 2014; Baptista et al., 2015b). The key factors for the sustainability of both short-term nutrient availability and long-term maintenance of soil organic matter under the systems of continuous dryland cultivation in sub-Saharan Africa may be the integration of water and nutrient management geared to ecologically sound and economically viable practices of land use (Buerkt et al., 2002). The optimisation of dryland crop production requires a better understanding of the interaction between combined SWC measures and locally available nutrient sources (i.e. compost and animal or green manure).

Despite the positive impact of the widespread implementation of SWC measures to combat land degradation in Cabo Verde (Baptista et al., 2015a), the steep slopes and limited area of arable land, together with the semi-arid and arid environments characterised by an irregular and poorly distributed rainy season with few heavy rains, continue to be challenges to dryland production. Maize (Zea mays) and beans, as the major dryland crops, occupy more than $80 \%$ of the dryland area under a low-input farming system that produces very low yields (RGA, 2004; FAO, 2014). Farmers in Cabo Verde, fearing economic losses due to the irregular rains, are reluctant to use fertilisers to improve the yield and soil fertility of their dryland fields. The only source of nutrients for the maize crop is the nitrogen $(\mathrm{N})$ provided by intercropped beans. The application of 
fertilisers on the steep slopes, though, may pose an environmental risk due to flooding in the valleys (Baptista et al., 2015a).

Several studies have attempted to quantify soil erosion in Cabo Verde, both at plot and watershed levels (Lopes \& Mayer, 1993; Mannaerts, 1993; Querido, 1999; Tavares, 2010), and some have evaluated techniques to reduce runoff and erosion (Smolikowski et al., 2001; Baptista et al., 2015b). However, the quantification of the effects of these measures on nutrient losses associated with runoff and erosion, and their impact on soil nutrient balances, have been neglected. Furthermore, the findings of the few studies that have monitored crop productivity under different SLM measures in Cabo Verde (Smolikowski et al., 2001; INIDA, 2006; Varela, 2012) have been inconsistent.

This study evaluated the efficacy of selected strategies of soil-water management (residue mulching, a soil surfactant, and pigeon-pea hedges) combined with organic amendments (compost and animal and green manures) on $\mathrm{N}$ and $\mathrm{P}$ losses with eroded soil, and runoff and on crop yields in Cabo Verde drylands. The study hypothesised that the synergetic effect of the combined strategies would significantly decrease nutrient losses related to runoff and erosion, and increase crop productivity.

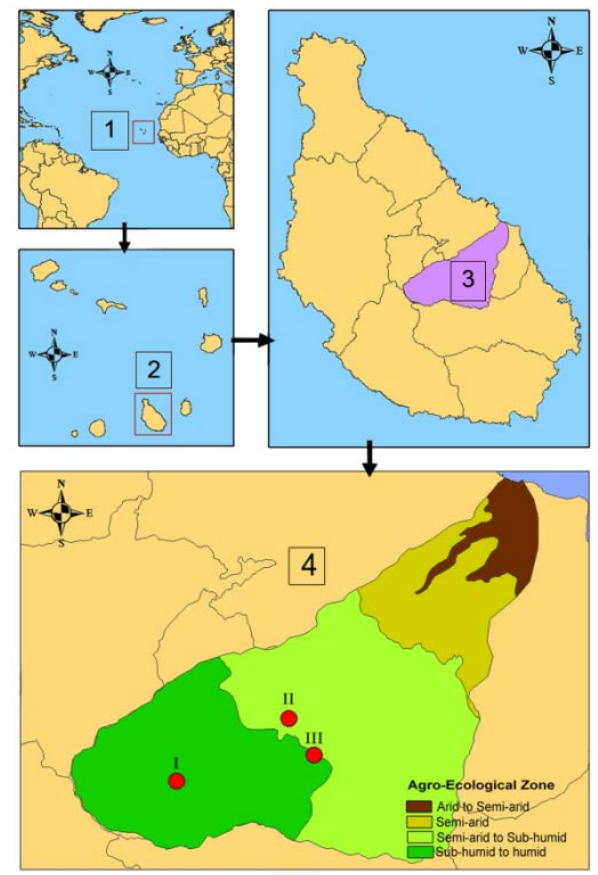

Figure 4.1.Location of (1) Cabo Verde, (2) Santiago, (3) the Ribeira Seca watershed, and (4) the experimental sites and Agro-Ecological zones. I, site I (São Jorge); II, site II (Serrado); and III, site III (Órgãos Pequenos). Adapted from (Baptista et al., 2015b). 


\subsection{Materials and Methods}

\subsubsection{Study site}

This study was conducted at three sites: São Jorge, site I $\left(15^{\circ} 03^{\prime} 05.7^{\prime \prime} \mathrm{N}, 23^{\circ} 36^{\prime} 29.2^{\prime \prime} \mathrm{W}\right)$;

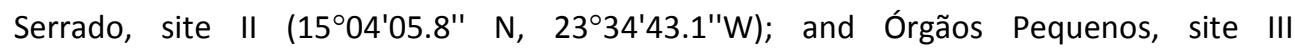
$\left(15^{\circ} 03^{\prime} 25.3^{\prime \prime} \mathrm{N}, 23^{\circ} 34^{\prime} 27.5^{\prime \prime} \mathrm{W}\right)$ in the Ribeira Seca watershed (RSW), which is the largest $\left(72 \mathrm{~km}^{2}\right)$ watershed on Santiago, the main agricultural island of Cabo Verde (Figure 4.1). Site I was at the Instituto Nacional de Investigação e Desenvolvimento Agrário (INIDA) station and the president of the institute gave permission to conduct the study. Sites II and III were at private lands and the landowners gave permission to conduct the study. At none of the sites, the study did not involve endangered or protected species.

The climate is characterised by a monomodal rainfall regime, with a 3-4 month humid season (July-October) and an 8-9 month dry season (November-June). The mean annual rainfall is extremely heterogeneous and has an irregular spatiotemporal distribution, with annual precipitation varying from $<200 \mathrm{~mm}$ downstream of the watershed to $650 \mathrm{~mm}$ upstream. The 30-year (1980-2010) mean annual rainfalls were 437, 300, and $310 \mathrm{~mm}$ at experimental sites I, II, and III, respectively, with most of the rain falling in August and September (INMG, 2010). Rainfed (i.e. dryland) agriculture, comprising maize, several varieties of beans, and groundnuts, is the predominant land use, covering $>83 \%$ of the area.

The sites were selected based on their specific characteristics of soil, agro-ecological zone (AEZ), slope, and agricultural practices. Site I is characterised by a low slope $(<10 \%)$ and loamy soil and is on a terraced field at a research station in the sub-humid to humid zone (351 $\mathrm{m}$ a.s.l. and mean annual rainfall of $437 \mathrm{~mm}$ ). Site II is characterised by a steep slope $(37 \%)$ and a sandy loamy soil and is in the semi-arid zone (183 $\mathrm{m}$ a.s.l. and mean annual rainfall of $300 \mathrm{~mm}$ ). Site III is characterised by a moderately steep slope (23\%) and a siltclay-loam soil and is located on a farm at the junction of the semi-arid and sub-humid zones (204 $\mathrm{m}$ a.s.l and mean annual rainfall of $310 \mathrm{~mm}$ ).

The initial physical and chemical properties of the soil $(0-20 \mathrm{~cm})$ varied among the three sites, but texture, bulk density, total $\mathrm{N}$ and extractable-P contents, and slope were homogeneous within each site (Table 4.1). The soils at sites I, II, and III had loam, sandy loam, and silt-clay-loam textures, respectively. Organic-matter content was low at sites II and III and average at site I. All sites were low in total N, particularly sites II and III with $<10 \mathrm{mg} \mathrm{N} \mathrm{g}^{-1}$ and the extractable-P content was average to high. Bulk density varied from 
$1.16 \mathrm{~g} \mathrm{~cm}^{-3}$ at site III to $1.42 \mathrm{~g} \mathrm{~cm}^{-3}$ at site I. The soil $\mathrm{pHs}$ were neutral to slightly alkaline. The rate of water infiltration was highest at site II and lowest at sites I and III.

Table 4.1. Soil properties $(0-20 \mathrm{~cm})$ at the experimental sites, site slopes, and total seasonal rainfall in 2012.

\begin{tabular}{|c|c|c|c|c|c|c|c|c|c|c|}
\hline Site & $\begin{array}{c}\text { Soil } \\
\text { texture }\end{array}$ & $\begin{array}{c}\text { Slope } \\
\text { (\%) }\end{array}$ & $\begin{array}{c}\mathrm{pH} \\
\left(\mathrm{H}_{2} \mathrm{O}\right)\end{array}$ & $\begin{array}{c}\text { Soil } \\
\text { moisture } \\
(\%)\end{array}$ & $\begin{array}{c}\mathrm{Bd}^{*} \\
\left(\mathrm{~g} \mathrm{~cm}^{-3}\right)\end{array}$ & $\begin{array}{l}\mathrm{OM}^{* *} \\
\left(\mathrm{~g} \mathrm{~kg}^{-1}\right)\end{array}$ & $\begin{array}{c}\text { Total } \\
\mathrm{N} \\
(\mathrm{g} \mathrm{kg} \\
\left.{ }_{1}\right)\end{array}$ & $\begin{array}{c}P_{\text {ext }} \\
\left(\mathrm{mg} \mathrm{kg}^{-1}\right)\end{array}$ & $\begin{array}{c}\mathrm{K}^{* * * *} \\
\left(\mathrm{~mm} \mathrm{~h}^{-1}\right)\end{array}$ & $\begin{array}{c}\text { Total } \\
\text { rainfall } \\
(\mathrm{mm})\end{array}$ \\
\hline 1 & Loam & 8 & 7.3 & 7.2 & 1.42 & 20.6 & 13.7 & 13.5 & 17.86 & 572 \\
\hline II & $\begin{array}{l}\text { Sandy } \\
\text { loam }\end{array}$ & 37 & 7.1 & 6.6 & 1.25 & 10.2 & 7.90 & 6.21 & 40.84 & 519 \\
\hline III & $\begin{array}{c}\text { Silt-clay- } \\
\text { loam }\end{array}$ & 23 & 6.9 & 8.1 & 1.16 & 10.7 & 10.6 & 8.75 & 10.67 & 540 \\
\hline
\end{tabular}

$\mathrm{Bd}$, bulk density; ${ }^{* *} \mathrm{OM}$, organic matter; ${ }^{* * *}$ extractable $\mathrm{P} ;{ }^{* * * *} \mathrm{~K}$, infiltration rate.

Table 4.2 Descriptions of the treatments applied at each experimental site in 2012 (adapted from (Baptista et al., 2015b) (fresh weights for compost with a moisture content of 35\% and manure with a moisture content of 10\%).

\begin{tabular}{|c|c|c|c|}
\hline Treatment & Site I (São Jorge) & Site II (Serrado) & Site III (Ó. Pequenos) \\
\hline TO & Traditional maize/bean & Traditional maize/bean & Traditional maize/bean \\
\hline (Control) & intercropping (no input) & intercropping (no input) & intercropping (no input) \\
\hline T1 & $\begin{array}{l}\text { Animal manure }\left(4 \mathrm{t} \mathrm{ha}^{-1}\right)+ \\
\text { soil surfactant }\left(1 \mathrm{~mL} \mathrm{~m}^{-2}\right)\end{array}$ & $\begin{array}{l}\text { Compost }\left(4 \mathrm{t} \mathrm{ha}^{-1}\right)+\text { soil surfactant } \\
\left(1 \mathrm{~mL} \mathrm{~m}^{-2}\right)\end{array}$ & $\begin{array}{l}\text { Animal manure }\left(4 \mathrm{t} \mathrm{ha}^{-1}\right)+\text { soil } \\
\quad \text { surfactant }\left(1 \mathrm{~mL} \mathrm{~m} \mathrm{~m}^{-2}\right)\end{array}$ \\
\hline $\mathrm{T} 2$ & $\begin{array}{l}\text { Compost }\left(4 \mathrm{t} \mathrm{ha}^{-1}\right)+\text { soil } \\
\text { surfactant }\left(1 \mathrm{~mL} \mathrm{~m}{ }^{-2}\right)\end{array}$ & $\begin{array}{l}\text { Pigeon-pea hedges + animal manure } \\
\left(4 \mathrm{t} \mathrm{ha}^{-1}\right)+\text { soil surfactant }\left(1 \mathrm{~mL} \mathrm{~m} \mathrm{~m}^{-2}\right)\end{array}$ & $\begin{array}{l}\text { Pigeon-pea hedges + green } \\
\text { manure ( } 1 \mathrm{t} \mathrm{ha}^{-1} \text { Leucaena } \\
\text { leucocephala prunings })+ \text { soil } \\
\text { surfactant }\left(1 \mathrm{~mL} \mathrm{~m}^{-2}\right)\end{array}$ \\
\hline T3 & $\begin{array}{l}\text { Mulch ( } 4 \mathrm{t} \mathrm{ha}^{-1} \text { banana } \\
\text { leaves) + compost }\left(4 \mathrm{t} \mathrm{ha}^{-1}\right)\end{array}$ & $\begin{array}{l}\text { Mulch ( } 4 \mathrm{t} \mathrm{ha}^{-1} \text { Panicum maximum } \\
\text { grass) + pigeon-pea hedges + animal } \\
\text { manure }\left(4 \mathrm{t} \mathrm{ha}^{-1}\right)\end{array}$ & $\begin{array}{l}\text { Mulch ( } 4 \mathrm{t} \mathrm{ha}^{-1} P \text {. maximum } \\
\text { grass) + pigeon-pea hedges + } \\
\text { green manure ( } 1 \mathrm{t} \mathrm{ha}^{-1} \mathrm{~L} \text {. } \\
\text { leucocephala prunings) }\end{array}$ \\
\hline
\end{tabular}

\subsubsection{Selection of technologies and treatments}

The methodology used to assess and select the promising technologies combined collective learning and decision-making with the application of evaluated global best practices, which was a simplified form of the participatory approach developed by (Schwilch et al., 2009) and applied by (Tavares et al., 2013). The selection of the treatments followed the procedure described by Baptista et al. (2015b). Most of the potential techniques (i.e.crop-residue mulching, vegetation barriers, organic amendments, and improved planting pits) were selected from the database of the World Overview of Conservation Approaches and Technologies (WOCAT, 2007). The local farmers who 
participated in the workshop for stakeholders, before the start of the field experiments, (1) identified the primary constraints of dryland production, (2) discussed potential technologies for addressing the constraints, (3) selected and ranked these technologies, and (4) grouped them into three categories representing low, medium, and high levels of investment.

The individual technologies for each study site were combined into three treatments (T1T3), which were compared with an untreated control (TO). The supplemented treatments differed among the sites, depending on the local availability of residue mulch, the type of organic amendments, and the preferences of the local farmers (Baptista et al., 2015b). Each supplemented treatment contained an organic amendment (compost or animal or green manure) and a water-management technique (residue mulch, a soil surfactant, and/or pigeon-pea (Cajanus cajan) hedges (Table 4.2).

The compost used in the experiments was prepared four months before the rainy season from raw organic materials (cow and poultry manure, ash, various dry crop residues, and Leucaena leucocephala prunings) enriched with $3 \mathrm{~kg}$ of a nitrogen/phosphorus/ potassium (NPK) inorganic fertiliser.

All materials were added in layers to fill a $1-\mathrm{m}$ deep $2 \times 1 \mathrm{~m}$ rectangular pit at the INIDA research station in Cabo Verde, watered weekly and then biweekly in a second pit for three months. The decomposed material was then covered and left to rest until its application in the field. The animal manure used at all sites was obtained from a farmyard and consisted of a well-decomposed mixture of cow manure and animal feed (i.e. crop residue). The green manure consisted of chopped fresh twigs of L. leucocephala obtained from nearby shrubs planted on the steep slopes for conserving soil and water.

Table 4.3 Nutrient contents (total $N, P, K)\left(\mathrm{g} \mathrm{kg}^{-1}\right)$ of the organic amendments (dry weights) used in the 2012 cropping season.

\begin{tabular}{cccc}
\hline Amendment & $\mathbf{N}$ & $\mathbf{P}$ & $\mathbf{K}$ \\
\hline Animal manure & 24.2 & 3.00 & 16.2 \\
Compost & 23.2 & 2.30 & 24.1 \\
Leucaena green manure & 38.1 & 2.20 & 17.0 \\
\hline
\end{tabular}

Table 4.3 presents the nutrient contents of the organic amendments applied in the two study seasons. Total N, P, and $\mathrm{K}$ contents of the organic amendments were analysed using STH soil-test kits (LaMotte, Eijkelkamp, NL): N and P by the colorimetric method. 
A

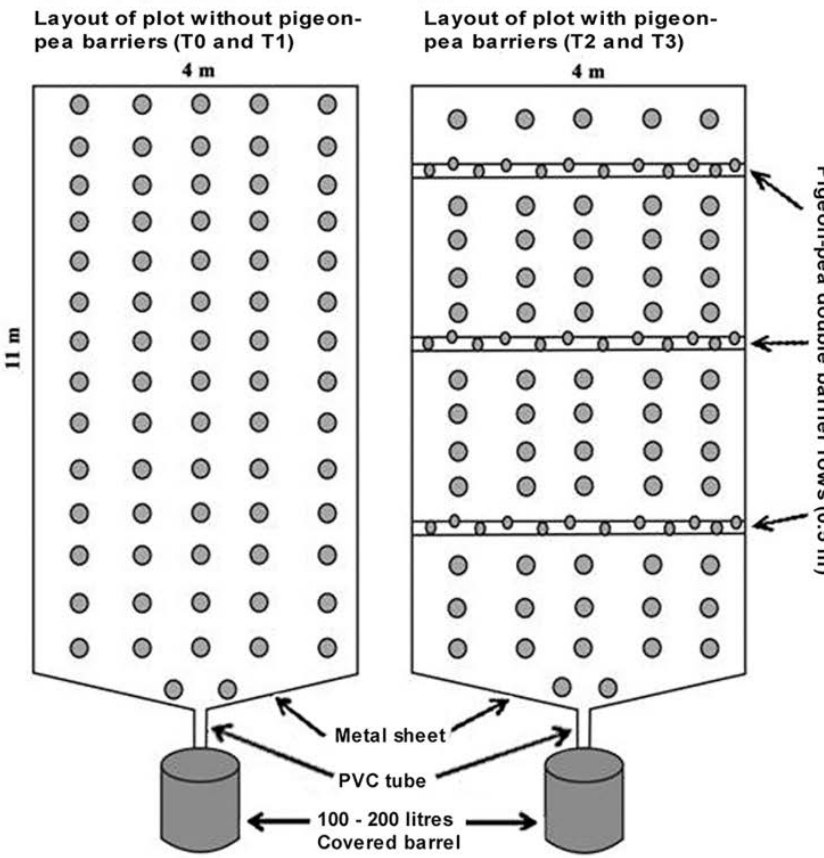

B

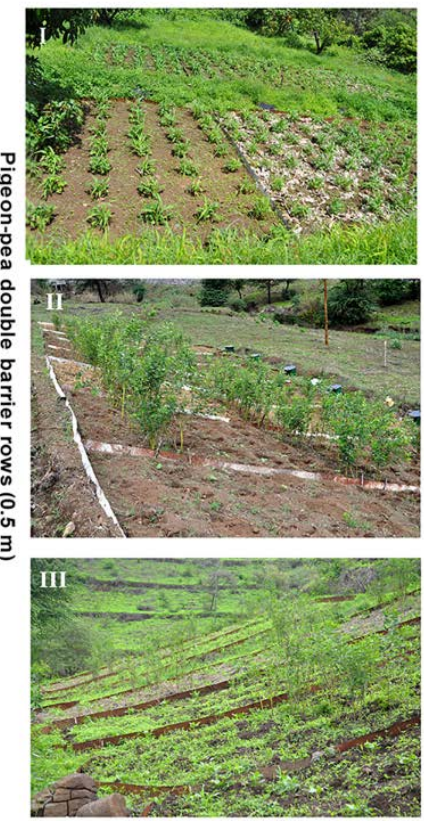

Figure 4.2 Layout and aspects of the experimental plots. (A) Schematic layout of the $11 \times 4 \mathrm{~m}$ erosion plots (sites II and III) with and without hedges, and (B) field layouts of the plots at sites I, II, and III.

\subsubsection{Experimental set-up}

The experiments were conducted during the 2012 rainy season, from August to October. The experimental plots were $11 \times 4 \mathrm{~m}$ in the two farm trials (Figure 4.2) and $6 \times 4 \mathrm{~m}$ in the trial at the research station. Each experimental plot was isolated with a metal sheet of 20 $\mathrm{cm}$ depth to prevent the entrance of runoff water from the other plots as well from subsurface flow. Despite different plot sizes, a pre-study indicated similar erosion and infiltration depth for the different sites. A barrel was placed at the bottom of each plot to collect runoff water. The experiments had a randomised design with three replicates of three supplemented treatments and one control. Figure $4.2 \mathrm{~A}$ and $4.2 \mathrm{~B}$ shows the field layout of the plots at each study site.

For T1-T3, planting pits (20 cm wide and $15 \mathrm{~cm}$ deep) were dug with a hoe $75 \mathrm{~cm}$ apart in the rows, with $80 \mathrm{~cm}$ between the rows. The organic amendments (compost or animal or green manure) were applied manually to the bottoms of the pits and covered with a small 
amount of soil before seeding. The agricultural soil surfactant IrrigAid Gold ACA 1848 (Aquatrols, New Jersey, USA) was diluted in water and sprayed on the soil surface with a hand-pressure atomiser after seeding. Three types of crop residue (banana leaves, sugarcane leaves, and P. maximum grass) were cut into small pieces and applied to the surface as mulch $\left(4 \mathrm{t} \mathrm{ha}^{-1}\right)$ to cover $60-80 \%$ of the soil surface.

\subsubsection{Crop management and measurements of crop growth and yield}

The crops used in the experiments were maize and two local types of beans (Vigna unguiculata, or cowpea, and Lablab purpureus, or feijão pedra). The crops were planted after the first significant rain $(>20 \mathrm{~mm}$ ) by placing three maize and four bean seeds (two of each type of bean) in each planting pit, thus forming a seed cluster. For the plots with pigeon-pea hedges (T2-T3), two pigeon-pea seeds were alternated along two lines $50 \mathrm{~cm}$ apart to form double-row hedges $3 \mathrm{~m}$ apart (Figure 4.2A). The maize and beans were planted between the hedges. The planting density was approximately 16300 seed clusters per hectare in all plots.

Weeds were removed from all plots twice during the rainy season, approximately three and six weeks after planting (Table 4.4), either with a hoe or by hand, with minimum disturbance of the soil, except for the control plots where weeding was always with a hoe. The heights of the maize plants were measured in all plots with a measuring tape, from the soil surface to the tip of the first fully developed leaf, taking six measurements per plot at flowering.

Composite samples of maize leaves were collected in each plot at the early maturity stage for the analysis of nutrient content at BLGG AgroXpertus, Wageningen, NL, using nearinfrared spectroscopy for N and SPZ2 for P and K (www.blgg.com).

Table 4.4 Dates of planting, weeding, and harvesting at each experimental site for the 2012 cropping season.

\begin{tabular}{cccc}
\hline Field operation & Site I & Site II & Site III \\
\hline $1^{\text {st }}$ significant rain & Aug 24 & Aug 24 & Aug 24 \\
Sowing of maize and beans & Aug 27 & Aug 28 & Aug 28 \\
$1^{\text {st }}$ weeding & Sep 17 & Sep 19 & Sep 20 \\
Harvest of $V$. unguiculata (cowpea) & Nov 08 & Nov 09 & Nov 07 \\
Harvest of maize & Dec 19 & Dec 20 & Dec18 \\
Harvest of $L$. purpureus (feijão pedra) & Mar 20 2013 & Mar 18 2013 & Mar 25 2013 \\
\hline
\end{tabular}

The maize and beans, excluding the outer rows, were harvested when dry. The yield of the dry maize was determined by weighing all cobs harvested from each plot. The bean yield 
was determined by weighing the dry grains harvested from each plot. Crop biomass, which consisted of all maize and bean plant material, was cut at the soil surface and weighed for all plots.

\subsubsection{Data collection and calculations}

Three composite soil samples were collected to a depth of $20 \mathrm{~cm}$ from each site at the end of the dry season before the experiments began. Laboratory analyses were conducted at INIDA. Soil texture was determined by the pipette method, bulk density by the core method (Blake \& Hartge, 1986), infiltration rate by minidisk infiltrometry (Decagon, Pullman, WA, USA), $\mathrm{pH}(\mathrm{H} 2 \mathrm{O})$ by a potentiometer, $\mathrm{N}$ content by Kjeldahl digestion (Jackson, 1982), extractable-P by the Olsen method, and organic-matter content by the Walkley Black method (Olsen \& Somers, 1982). Daily rainfall was measured with a simple rain gauge installed at each experimental site.

Automatic Em5b data loggers with moisture sensors (Decagon Devices, Pullman, WA, USA) were installed in each plot at a depth of $15 \mathrm{~cm}$ (only one at each site due to financial restrictions) to register trend in the volumetric moisture content of the soil every $30 \mathrm{~min}$ under the various treatments. Daily moisture contents were estimated by averaging the 30-min values. Runoff water and eroded soil were collected after each erosive rain following the procedure described in (Baptista et al., 2015b). After measuring the volume of the runoff, $1 \mathrm{~L}$ was taken to the laboratory for analysis. $\mathrm{NO}_{3}$ concentrations were determined by the Aquamerck colorimetric method, $\mathrm{PO}_{4}$ concentrations were determined by Olsen spectrophotometry (Olsen \& Sommers, 1982), and the $\mathrm{pH}$ was measured with a potentiometer.

After filtration and oven-drying, the eroded soil was weighed, and the amount of soil loss $\left(\mathrm{g} \mathrm{m}^{-2}\right)$ was estimated for each plot. The seasonal soil loss per plot was calculated by totalling the amount of soil lost from each erosive rain. The seasonal runoff coefficient $(\mathrm{Cr})$ was calculated for total growing-season erosive periods of rain using the equation (Baptista et al., 2015b):

$$
C r=(Q / R) \times 100
$$

where $Q$ is the runoff volume (in $\mathrm{mm}$ ) and $\mathrm{R}$ is the total rainfall producing runoff (in $\mathrm{mm}$ ). The runoff and eroded soil were considered to be the only sources of nutrient losses (see (Baptista et al., 2015b) for detailed data analyses of the runoff and sediments). 
$\mathrm{NO}_{3}$ and $\mathrm{PO}_{4}$ concentrations in the runoff and eroded soil were determined by colorimetry using STH soil-test kits (LaMotte, Eijkelkamp, $\mathrm{NL}$ ). Nutrient losses $\left(\mathrm{NO}_{3}-\mathrm{N}\right.$ and $\mathrm{PO}_{4}-\mathrm{P}$ ) per plot and from each rain in the runoff and sediments were estimated following Ali et al. (2007):

$$
\begin{aligned}
& \text { Nutrient loss in runoff }\left(\mathrm{mg} \cdot \mathrm{m}^{-2}\right) \\
& =\text { nutrient concentration in runoff }\left(\mathrm{mg} \cdot \mathrm{L}^{-1}\right) \times \operatorname{total} \operatorname{runoff}\left(\mathrm{L} \cdot \mathrm{m}^{-2}\right) \\
& \text { Nutrient loss in eroded soil }\left(\mathrm{mg} \cdot \mathrm{m}^{-2}\right) \\
& =\text { nutrient concentration in eroded soil }\left(\mathrm{mg} \cdot \mathrm{g}^{-1}\right) \\
& \times \text { total soil loss }\left(\mathrm{g} \cdot \mathrm{m}^{-2}\right)
\end{aligned}
$$

Partial $\mathrm{NO}_{3}-\mathrm{N}$ and $\mathrm{PO}_{4}-\mathrm{P}$ balances were estimated from the amounts added with the organic amendments and the amounts lost in the runoff and sediments.

\subsubsection{Data Analysis}

All statistical analyses were performed using IBM SPSS 19.0 statistics software. The data were tested for normality with the Kolmogorov-Smirnov test. Analyses of variance tested for the significance of the supplemented treatments on plant height, crop and biomass yields, seasonal $\mathrm{NO}_{3}-\mathrm{N}$ and $\mathrm{PO}_{4}-\mathrm{P}$ losses in the runoff and eroded soil. We used the posthoc Dunnett's T3 test for non-homogenous variances to identify significant differences among the treatments. All tests were deemed statistically significant at a probability value of 0.05. A principal component analysis (PCA) was conducted for treatment, seasonal runoff and eroded soil, site slope, seasonal rainfall, seasonal $\mathrm{NO}_{3}-\mathrm{N}$ and $\mathrm{PO}_{4}-\mathrm{P}$ losses, soil moisture, yield, and biomass. Components with eigenvalues over Keiser's criterion of 1 were extracted. Pearson correlation analyses of the variables were also performed.

\subsection{Results}

\subsubsection{Rainfall distribution}

The total seasonal rainfalls in the 2012 rainy season were 572,519 , and $540 \mathrm{~mm}$ at sites I, II, and III, respectively (Table 4.1), which were substantially higher than the average precipitation for August to October for 1980-2010. The seasonal rainfall did not substantially differ among the sites, but the distribution varied considerably (Figure 4.3). The first rain fell in late August, and rains were well distributed throughout September, with 12 days of rain, but no rain fell in October. Of 18 total rainy days, five rainfalls were 
$<20 \mathrm{~mm}$, only one was $>50 \mathrm{~mm}$, and the others were $20-50 \mathrm{~mm}$ for all three sites (Figure 4.3).

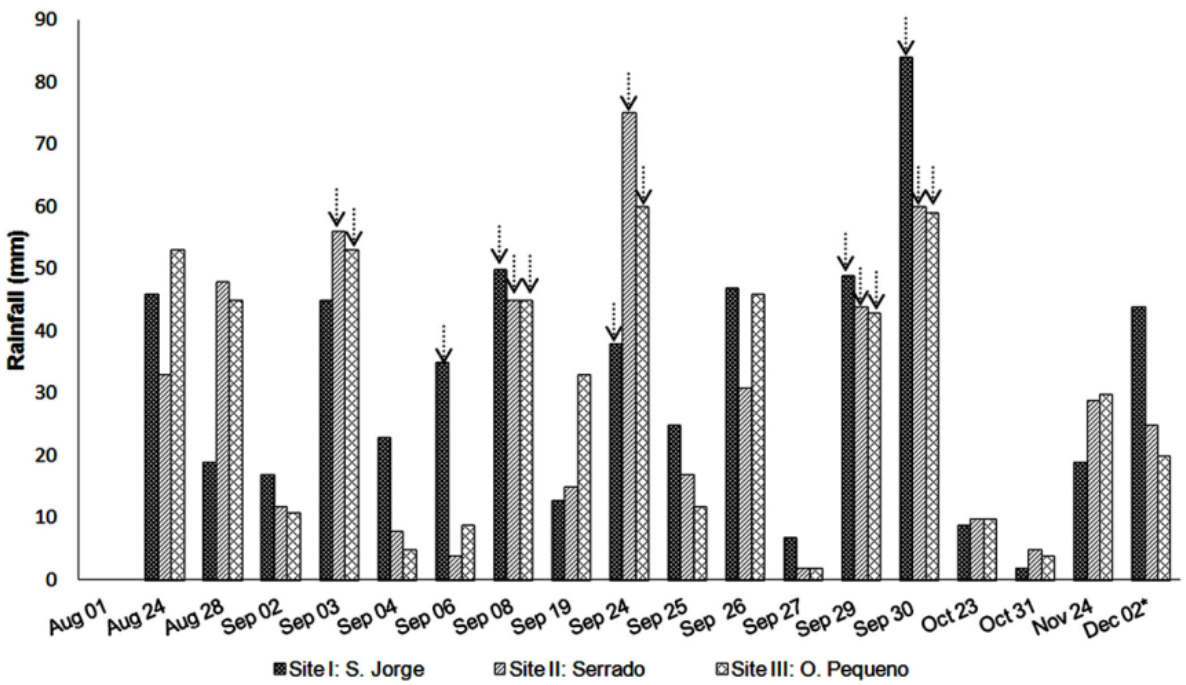

Figure 4.3 Rainfall distribution over the 2012 rainy season at the three experimental sites. The arrows indicate daily rainfall causing runoff. * Rainfall accumulated between Nov 30 and Dec 2.

Table 4.5 Effects of the treatments on seasonal runoff, runoff coefficient, seasonal soil loss and concentrations of nutrients (mean \pm standard deviation) in the runoff and eroded soil. Different letters indicate significant differences (Dunnett's T3 test) between the treatments within the same site $(P<0.05)$ : $a<b<c$. See Table 4.2 for treatment descriptions.

\begin{tabular}{|c|c|c|c|c|c|c|c|c|}
\hline Site & $\begin{array}{l}\text { Treat- } \\
\text { ment }\end{array}$ & $\begin{array}{l}\text { Runoff } \\
\left(\mathrm{L} \mathrm{m}^{-2}\right)\end{array}$ & $\begin{array}{c}\text { Runoff } \\
\text { coefficient } \\
(\%)\end{array}$ & $\begin{array}{c}\text { Eroded } \\
\text { soil }^{*} \\
\left(\mathrm{~g} \mathrm{~m}^{-2}\right)\end{array}$ & $\begin{array}{c}\mathrm{NO}_{3}-\mathrm{N} \text { in } \\
\text { runoff } \\
\left(\mathrm{mg} \mathrm{L}^{-1}\right)\end{array}$ & $\begin{array}{c}\mathrm{PO}_{4}-\mathrm{P} \text { in } \\
\text { runoff } \\
\left(\mathrm{mg} \mathrm{L}^{-1}\right)\end{array}$ & $\begin{array}{l}\mathrm{NO}_{3}-\mathrm{N} \text { in } \\
\text { eroded soil } \\
\left(\mathrm{mg} \mathrm{g}^{-1}\right)\end{array}$ & $\begin{array}{c}\mathrm{PO}_{4}-\mathrm{P} \text { in } \\
\text { Eroded soil } \\
\left(\mathrm{mg} \mathrm{g}^{-1}\right)\end{array}$ \\
\hline \multirow[t]{4}{*}{1} & T0 & $12.1 \pm 1.76 \mathrm{c}$ & $4.1 \pm 0.5$ & $38.9 \pm 17.6 \mathrm{c}$ & $3.24 \pm 2.71 a$ & $0.06 \pm 0.06 a$ & $5.30 \pm 3.61 a$ & $18.8 \pm 13.7 a$ \\
\hline & $\mathrm{T} 1$ & $6.81 \pm 1.08 \mathrm{~b}$ & $2.3 \pm 0.3$ & $8.99 \pm 3.66 b$ & $2.20 \pm 1.67 a$ & $0.06 \pm 0.07 a$ & $4.37 \pm 3.03 a$ & $14.7 \pm 12.6 \mathrm{a}$ \\
\hline & $\mathrm{T} 2$ & $8.33 \pm 2.65 b$ & $3.0 \pm 0.8$ & $9.90 \pm 6.42 b$ & $2.51 \pm 1.99 a$ & $0.03 \pm 0.03 a$ & $3.45 \pm 2.25 a$ & $12.8 \pm 10.2 a$ \\
\hline & T3 & $0.11 \pm 0.19 a$ & $0 \pm 0.1$ & $0.02 \pm 0.01 a$ & $2.08 \pm 2.03 a$ & $0.04 \pm 0.06 a$ & $2.44 \pm 1.71 \mathrm{a}$ & $8.71 \pm 6.81 a$ \\
\hline \multirow[t]{4}{*}{ II } & TO & $20.1 \pm 0.23 c$ & $6.7 \pm 0.1$ & $104 \pm 18.4 c$ & $4.40 \pm 2.26 \mathrm{a}$ & $0.07 \pm 0.05 a$ & $2.80 \pm 1.65 a$ & $8.30 \pm 4.15 a$ \\
\hline & $\mathrm{T} 1$ & $17.6 \pm 0.53 b c$ & $5.7 \pm 0.2$ & $35.2 \pm 16.4 \mathrm{~b}$ & $3.06 \pm 2.12 a$ & $0.02 \pm 0.01 a$ & $2.24 \pm 1.21 \mathrm{a}$ & $5.78 \pm 4.53 a$ \\
\hline & $\mathrm{T} 2$ & $15.4 \pm 2.29 b$ & $5.1 \pm 0.7$ & $48.1 \pm 18.4 b$ & $3.24 \pm 2.03 a$ & $0.04 \pm 0.03 a$ & $1.30 \pm 1.14 \mathrm{a}$ & $5.27 \pm 3.56 \mathrm{a}$ \\
\hline & T3 & $0.17 \pm 0.10 \mathrm{a}$ & $0.1 \pm 0.0$ & $0.05 \pm 0.04 a$ & $3.85 \pm 2.18 \mathrm{a}$ & $0.06 \pm 0.04 a$ & $2.38 \pm 1.90 \mathrm{a}$ & $5.62 \pm 3.18 a$ \\
\hline \multirow[t]{4}{*}{ III } & TO & $16.4 \pm 1.64 b$ & $5.6 \pm 0.6$ & $156 \pm 15.6 c$ & $4.83 \pm 2.64 a$ & $0.06 \pm 0.04 a$ & $8.51 \pm 3.97 a$ & $17.8 \pm 8.88 a$ \\
\hline & $\mathrm{T} 1$ & $14.8 \pm 1.59 \mathrm{~b}$ & $5.1 \pm 0.5$ & $41.0 \pm 15.1 \mathrm{~b}$ & $2.51 \pm 1.71 \mathrm{a}$ & $0.03 \pm 0.05 a$ & $5.92 \pm 3.46 a$ & $13.3 \pm 8.25 a$ \\
\hline & $\mathrm{T} 2$ & $11.3 \pm 4.25 b$ & $3.9 \pm 1.4$ & $25.0 \pm 14.4 \mathrm{~b}$ & $2.69 \pm 1.70 \mathrm{a}$ & $0.04 \pm 0.02 a$ & $6.29 \pm 4.21 a$ & $12.8 \pm 7.04 a$ \\
\hline & T3 & $0.75 \pm 1.30 \mathrm{a}$ & $0.3 \pm 0.1$ & $0.68 \pm 0.12 a$ & $3.85 \pm 2.18 a$ & $0.03 \pm 0.02 a$ & $6.72 \pm 3.37 a$ & $13.2 \pm 6.12 \mathrm{a}$ \\
\hline
\end{tabular}

$\mathrm{mg} \mathrm{m}^{-2}=10^{-2} \mathrm{~kg} \mathrm{ha}^{-1}$. 


\subsubsection{Effects of the treatments on soil moisture}

Continuous soil-moisture trends at a depth of $15 \mathrm{~cm}$ in the planting pits exhibited different behaviours among the three sites and throughout the growing season (Figure 4.4).

At site I, the moisture contents of the supplemented treatments were either identical to or lower than the control, except during the wet period after the heavy rain of Sep 29 when the moisture content was higher in T1 (Figure 4.4I). The moisture content in T1, however, was lower than the contents of the other treatments during dry periods. T3 had similar moisture contents as T0 throughout the season, while the other supplemented treatments had lower moisture contents. The moisture contents in the treatments had the order $\mathrm{T} 0 \geq \mathrm{T} 3>\mathrm{T} 1>\mathrm{T} 2$.

At site II, T1-T3 had soil-moisture contents lower than that in T0, except for the first month of the season when T2 had a higher moisture content (Figure 4.4II). The moisture contents had the order $\mathrm{T} 0 \geq \mathrm{T} 1>\mathrm{T} 3>\mathrm{T} 2$. $\mathrm{T} 2$ had a very low moisture content throughout the experimental season, and the content did not vary a lot following rains.

At site III, the supplemented treatments contributed to increases soil-moisture content in the planting pits relative to the control (Figure $4.4 \mathrm{III}$ ) and the increases were larger after long periods of drought. Early in the season when plant cover was low, soil moisture was higher than in TO only in T3.

The soil-moisture contents of the planting pits differed among the sites, being highest (14$48 \%$ ) at site III, lowest (3-21\%) at site II, and intermediate (13-30\%) at site I.

\subsubsection{Effects of the treatments on nutrient losses in the runoff and sediments}

\section{Runoff and soil loss}

All supplemented treatments produced significantly less seasonal runoff than the control, with T3 significantly outperforming T1 and T2 at all three sites (Table 4.5). T3 had the lowest amount of seasonal runoff $\left(0.1 \mathrm{~L} \mathrm{~m}^{-2}\right)$ at site $\mathrm{I}$, and T0 had the highest amount $(20 \mathrm{~L}$ $\mathrm{m}^{-2}$ ) at site II. T3 reduced seasonal runoff relative to T0 by $95 \%$ (site III) to $99 \%$ (sites I and II). Runoff generation was in the orders $\mathrm{T} 3<\mathrm{T} 1=\mathrm{T} 2<\mathrm{T} 0$ at site I and $\mathrm{T} 3<\mathrm{T} 1=\mathrm{T} 2=\mathrm{T} 0$ at sites II and III, indicating significant differences. 


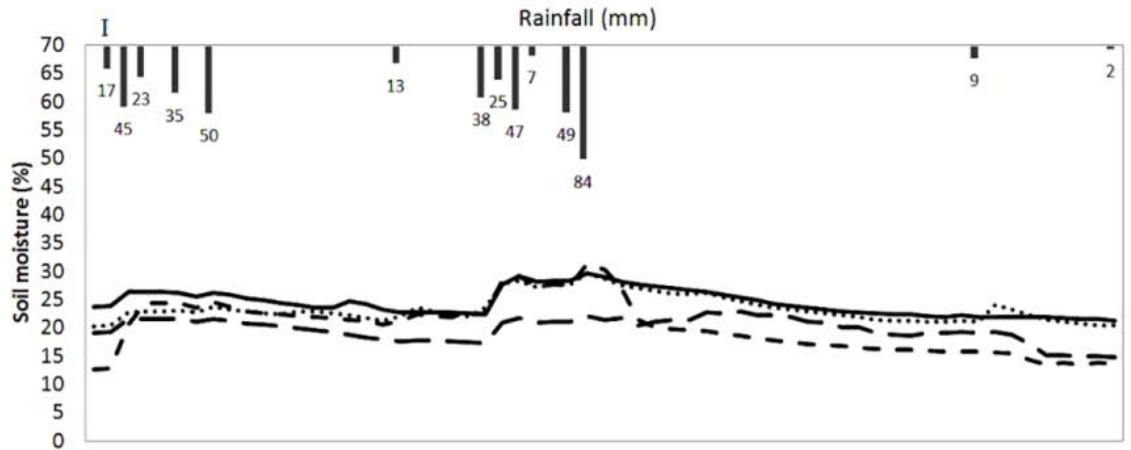

II

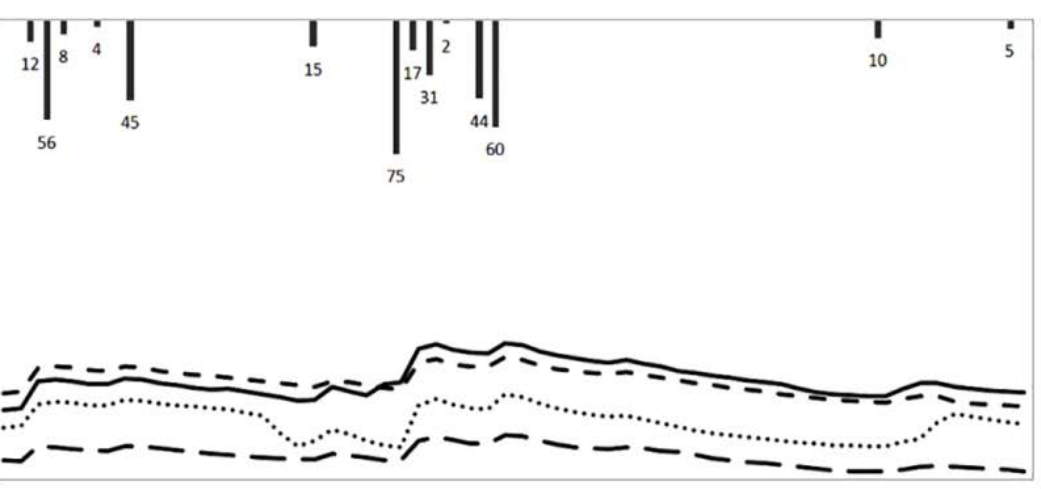

III

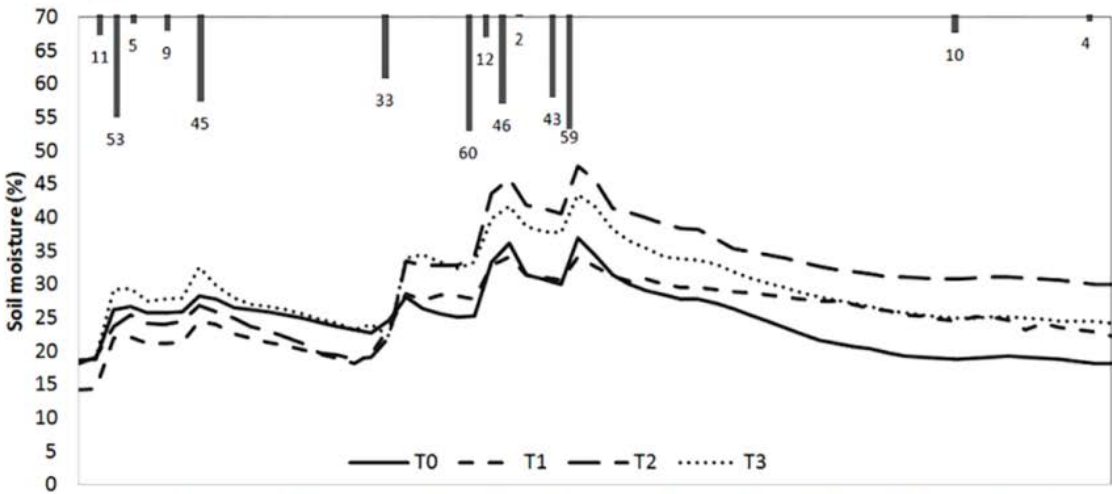

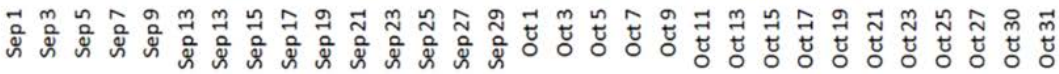

Figure 4.4 Daily soil-moisture trends (\% by volume) in the planting pits of the various treatments during the 2012 rainy season. The bars represent rainfall per rain. The higher moisture peaks correspond to the rains. 
Similarly, all supplemented treatments generally lost significantly $(P<0.05)$ less soil than the control, with T3 registering the lowest amount of soil loss at all three sites (Table 4.5). Site III lost the most soil, reaching 1.6, 0.4, 0.3, and $0.01 \mathrm{Mg} \mathrm{ha}^{-1}$ in T0, T1, T2, and T3, respectively. T1 did not generally differ significantly $(P>0.05)$ from $T 2$, but both lost significantly $(P<0.05)$ less soil than T0. The order of soil-loss reduction was $\mathrm{T} 3<\mathrm{T} 1=\mathrm{T} 2<\mathrm{T} 0$ for all sites (see Baptista et al., 2015b for details).

\section{$\mathrm{NO}_{3}-\mathrm{N}$ and $\mathrm{PO}_{4}-\mathrm{P}$ concentrations in runoff and eroded soil}

Nutrient $\left(\mathrm{NO}_{3}-\mathrm{N}\right.$ and $\left.\mathrm{PO}_{4}-\mathrm{P}\right)$ concentrations in the runoff and eroded soil did not differ significantly among the supplemented treatments at any of the sites relative to TO (Table 4.5). The $\mathrm{NO}_{3}-\mathrm{N}$ concentration (2.20-4.83 mg L${ }^{-1}$ ), however, was higher than the $\mathrm{PO}_{4}-\mathrm{P}$ concentration (0.02-0.07 mg L $\mathrm{m}^{-1}$ ) in the runoff, and the $\mathrm{PO}_{4}-\mathrm{P}$ concentration (5.27-18.8 mg $\mathrm{g}^{-1}$ ) was higher than the $\mathrm{NO}_{3}-\mathrm{N}$ concentration $\left(1.30-8.51 \mathrm{mg} \mathrm{g}^{-1}\right)$ in the eroded soil. Nutrient concentrations in the runoff from the supplemented treatments were very similar among the sites but differed from those in the eroded soil in the orders III>I>II for $\mathrm{NO}_{3}-\mathrm{N}$ and I $\geq \mathrm{III}>\mathrm{II}$ for $\mathrm{PO}_{4}-\mathrm{P}$. The $\mathrm{NO}_{3}-\mathrm{N}$ concentrations in runoff ranged from $2.20 \mathrm{mg} \mathrm{L}^{-1}$ (T1, site I) to $4.83 \mathrm{mg} \mathrm{L}^{-1}$ (TO, site III), and those of $\mathrm{PO}_{4}-\mathrm{P}$ ranged from $0.02 \mathrm{mg} \mathrm{L}^{-1}$ (T1) to $0.07 \mathrm{mg} \mathrm{L}^{-1}$ (TO) both at site II. In the eroded soil, the $\mathrm{NO}_{3}-\mathrm{N}$ concentrations ranged from $1.30 \mathrm{mg} \mathrm{g}^{-1}$ (T2, site II) to $8.51 \mathrm{mg} \mathrm{g}^{-1}$ (TO, site III) and those of $\mathrm{PO}_{4}-\mathrm{P}$ ranged from $5.27 \mathrm{mg}$ $\mathrm{g}^{-1}$ (T2, site II) to $18.8 \mathrm{mg} \mathrm{g}^{-1}$ (T0, site I). The mean $\mathrm{NO}_{3}-\mathrm{N}$ concentrations in the runoffs were $2.51,3.64$, and $3.47 \mathrm{mg} \mathrm{L}^{-1}$ for sites I, II, and III, respectively, and the mean $\mathrm{PO}_{4}-\mathrm{P}$ concentration was $0.05 \mathrm{mg} \mathrm{L}^{-1}$ for all sites. The mean $\mathrm{NO}_{3}-\mathrm{N}$ concentrations in the eroded soil were $3.89,2.20$, and $6.86 \mathrm{mg} \mathrm{g}^{-1}$, and the mean $\mathrm{PO}_{4}-\mathrm{P}$ concentrations were $13.8,6.18$, and $14.3 \mathrm{mg} \mathrm{g}^{-1}$, at sites I, II, and III, respectively (Table 4.5).

Table 4.5 Contributions of runoff and eroded soil to seasonal $\mathrm{NO}_{3}-\mathrm{N}$ and $\mathrm{PO}_{4}-\mathrm{P}$ at each experimental site in the various treatments. See Table 4.2 for treatment descriptions.

\begin{tabular}{|c|c|c|c|c|c|}
\hline \multirow[t]{2}{*}{ Site } & \multirow[t]{2}{*}{ Treatment } & \multicolumn{2}{|c|}{$\mathrm{NO}_{3}-\mathrm{N}$ loss (\%) } & \multicolumn{2}{|c|}{$\mathrm{PO}_{4}-\mathrm{P}$ loss (\%) } \\
\hline & & Runoff & Eroded soil & Runoff & Eroded soil \\
\hline \multirow[t]{4}{*}{ I } & T0 & 11 & 89 & 8 & 92 \\
\hline & $\mathrm{T} 1$ & 28 & 72 & 13 & 87 \\
\hline & $\mathrm{T} 2$ & 49 & 51 & 28 & 72 \\
\hline & T3 & 80 & 20 & 0 & 100 \\
\hline \multirow[t]{4}{*}{ II } & TO & 23 & 77 & 9 & 91 \\
\hline & $\mathrm{T} 1$ & 40 & 60 & 21 & 79 \\
\hline & $\mathrm{T} 2$ & 44 & 56 & 27 & 73 \\
\hline & T3 & 89 & 11 & 100 & 0 \\
\hline \multirow[t]{4}{*}{ III } & TO & 5 & 95 & 3 & 97 \\
\hline & $\mathrm{T} 1$ & 18 & 82 & 6 & 94 \\
\hline & $\mathrm{T} 2$ & 27 & 73 & 12 & 88 \\
\hline & T3 & 44 & 56 & 27 & 73 \\
\hline
\end{tabular}

$\mathrm{NO}_{3}-\mathrm{N}$ and $\mathrm{PO}_{4}-\mathrm{P}$ losses 
The amounts of runoff and soil loss in 2012 were low, but the treatments had highly significant effects on the losses of both $\mathrm{NO}_{3}-\mathrm{N}$ and $\mathrm{PO}_{4}-\mathrm{P}$ related to runoff and eroded soil
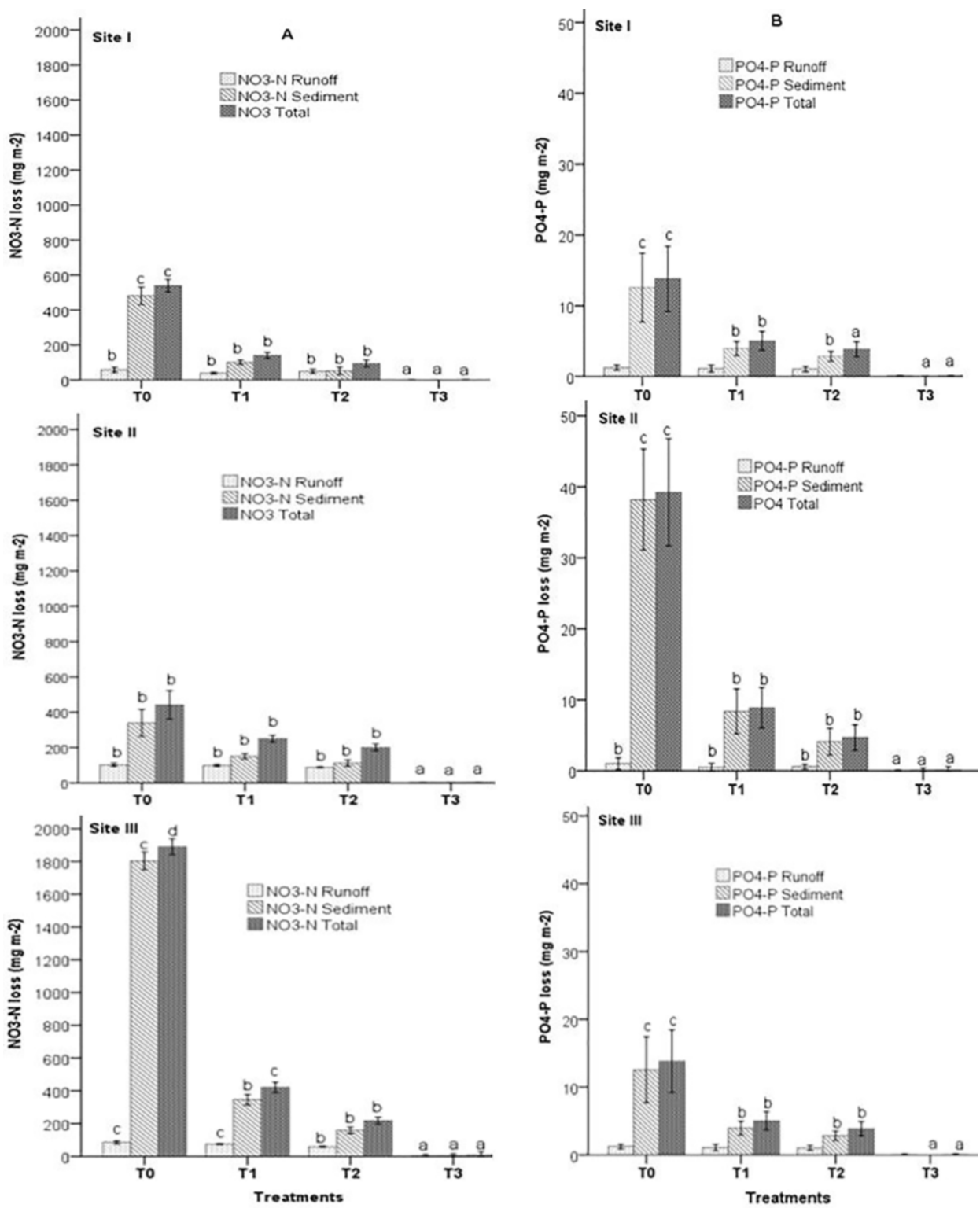

Figure 4.5 Annual losses of (A) $\mathrm{NO}_{3}-\mathrm{N}$ and (B) $\mathrm{PO}_{4}-\mathrm{P}$ in the eroded soil and runoff for the various treatments. Different letters indicate significant differences (Dunnett's T3 test) within the same site and category ( $P<0.05): a<b<c<d$. Error bars are standard deviation. See Table 4.2 for treatment descriptions. 
(Figure 4.5) at all sites. T0 had the significant highest $(P<0.01)$ and $T 3$ the significant lowest $(\mathrm{P}<0.01$ ) seasonal NO3-N loss at all sites (Figure 4.5A). T0 had losses of 539, 442, and 1890 $\mathrm{mg} \mathrm{NO}_{3}-\mathrm{N} \mathrm{m}^{-2}$ at sites I, II, and III, respectively, with 89,77 , and 95\% lost with the eroded soil and 11, 23 and 5\% lost in the runoff (Table 4.6). Both T1 and T2 at site I lost significantly $(P<0.05)$ less $\mathrm{NO}_{3}-\mathrm{N}$ than $\mathrm{TO}$, but the losses did not differ between them. At site III, T3 lost significantly less total $\mathrm{NO}_{3}-\mathrm{N}$ than $\mathrm{T} 1$ and $\mathrm{T} 2$.

$\mathrm{NO}_{3}-\mathrm{N}$ at sites I and II was lost mainly with the eroded soil in TO-T2 and mainly in the runoff in T3. $\mathrm{N}$ was lost at site III mainly with the eroded soil in all treatments. Total $\mathrm{NO}_{3}-\mathrm{N}$ losses in T3 were negligible at sites I and II and low $\left(9.36 \mathrm{mg} \mathrm{m}^{-2}\right)$ at site III. The losses in T1 and $\mathrm{T} 2$ were not significantly different.

Similarly, to $\mathrm{NO}_{3}-\mathrm{N}$, total $\mathrm{PO}_{4}-\mathrm{P}$ loss was significantly highest in $\mathrm{TO}$ and significantly lowest in T3 at all sites (Figure 4.5B). TO had losses of 16.6, 13.8, and $39.2 \mathrm{mg} \mathrm{PO}_{4}-\mathrm{P} \mathrm{m}^{-2}$ at sites I, $\mathrm{II}$, and III, respectively (Figure $4.5 \mathrm{~B}$ ), with $>90 \%$ in the sediments and $<10 \%$ in the runoff (Table 4.6). Both T1 and T2 lost significantly $(P<0.05)$ less $\mathrm{PO}_{4}-\mathrm{P}$ than $\mathrm{TO}$ at sites I and III, but the losses did not differ between them. At site II, T3 lost significantly less total $\mathrm{PO}_{4}-\mathrm{P}$ than $\mathrm{T} 1$ and $\mathrm{T} 2$. The amount of $\mathrm{PO}_{4}-\mathrm{P}$ lost in the sediments was higher for $\mathrm{T} 1$ than for $\mathrm{T} 2$.

The runoff and soil losses, $\mathrm{NO}_{3}-\mathrm{N}$, and $\mathrm{PO}_{4}-\mathrm{P}$ were low, but all supplemented treatments substantially reduced the losses relative to the control (Table 4.7). T3 reduced the loss of all parameters by nearly $100 \%$ at all sites. The reductions in the losses of total $\mathrm{NO}_{3}-\mathrm{N}$ varied from 43 to $78 \%$ in $\mathrm{T} 1$ and from 55 to $88 \%$ in T2. Similar values and trends were observed for $\mathrm{PO}_{4}-\mathrm{P}$. The reductions in the losses of all parameters were lowest at site II and highest at site III.

\section{Nutrient inputs versus losses}

The total nutrients ( $\mathrm{N}$ and $\mathrm{P}$ ) added with the organic amendments in T1-T3 were higher than the nutrient losses as $\mathrm{NO}_{3}-\mathrm{N}$ and $\mathrm{PO}_{4}-\mathrm{P}$ in the runoff and eroded soil (Table 4.8). The fractions of the nutrient inputs lost in the runoff and sediments were very low in all treatments, with the $\mathrm{NO}_{3}-\mathrm{N}$ losses ranging from negligible in $\mathrm{T} 3$ at all sites to $5.7 \%$ from the $\mathrm{N}$ added by the amendments in $\mathrm{T} 2$ at site III. TO had the highest nutrient losses at all sites and T3 had the lowest. TO, which received no nutrient inputs, lost 5.39 and $0.17 \mathrm{~kg}$ ha ${ }^{-1}$ of $\mathrm{NO}_{3}-\mathrm{N}$ and $\mathrm{PO}_{4}-\mathrm{P}$, respectively, at site $\mathrm{I}$, and 4.42 and $0.14 \mathrm{~kg} \mathrm{ha}^{-1}$, respectively, at site II. The losses were higher at site III, with 18.9 and $0.4 \mathrm{~kg}^{-1}$ for $\mathrm{NO}_{3}-\mathrm{N}$ and $\mathrm{PO}_{4}-\mathrm{P}$, respectively. The losses of both nutrients were negligible in $\mathrm{T} 3$ at all sites, indicating the effectiveness of this treatment in reducing nutrient losses. 
Table 4.7 Effects of the treatments on the seasonal reduction of runoff, soil loss, $\mathrm{NO}_{3}-\mathrm{N}$ and $\mathrm{PO}_{4}-\mathrm{P}$ losses relative to the control at each experimental site (\%). See Table 4.2 for treatment descriptions.

\begin{tabular}{|c|c|c|c|c|c|}
\hline Site & Treatment & Runoff (\%) & Eroded soil (\%) & $\mathrm{NO}_{3}-\mathrm{N}(\%)$ & $\mathrm{PO}_{4}-\mathrm{P}(\%)$ \\
\hline \multirow[t]{4}{*}{$\mathrm{I}$} & T0 & 0 & 0 & 0 & 0 \\
\hline & T1 & 44 & 77 & 74 & 76 \\
\hline & $\mathrm{T} 2$ & 31 & 75 & 83 & 83 \\
\hline & T3 & 99 & 100 & 100 & 100 \\
\hline \multirow[t]{4}{*}{ II } & TO & 0 & 0 & 0 & 0 \\
\hline & $\mathrm{T} 1$ & 12 & 66 & 43 & 64 \\
\hline & $\mathrm{T} 2$ & 23 & 54 & 55 & 72 \\
\hline & T3 & 99 & 100 & 100 & 100 \\
\hline \multirow[t]{4}{*}{ III } & T0 & 0 & 0 & 0 & 0 \\
\hline & $\mathrm{T} 1$ & 10 & 74 & 78 & 77 \\
\hline & $\mathrm{T} 2$ & 31 & 84 & 88 & 88 \\
\hline & T3 & 95 & 100 & 100 & 100 \\
\hline
\end{tabular}

Table 4.8 Total $N$ and $P$ input from the organic amendments, their losses as $\mathrm{NO}_{3}-\mathrm{N}$ and $\mathrm{PO}_{4}-\mathrm{P}$ in the runoff and eroded soil for the various treatments at each experimental site in the 2012 cropping season. Different letters indicate significant differences (Dunnett's T3 test) within the same site $(P<0.05): a<b<c<d$. See Table 4.2 for treatment descriptions.

\begin{tabular}{|c|c|c|c|c|c|c|c|}
\hline \multirow[t]{2}{*}{ Site } & \multirow[t]{2}{*}{ Treatment } & \multicolumn{2}{|c|}{ Inputs from amendments } & \multicolumn{2}{|c|}{$\begin{array}{l}\text { Losses in runoff and } \\
\text { sediments }\end{array}$} & \multicolumn{2}{|c|}{$\begin{array}{c}\text { Losses from input } \\
\text { nutrients }\end{array}$} \\
\hline & & $\begin{array}{c}\text { Total N (kg } \\
\text { ha }^{-1} \text { ) }\end{array}$ & $\begin{array}{c}\text { Total P (kg } \\
\left.\text { ha }^{-1}\right)\end{array}$ & $\begin{array}{c}\mathrm{NO}_{3}-\mathrm{N}(\mathrm{kg} \\
\left.\mathrm{ha}^{-1}\right)\end{array}$ & $\begin{array}{c}\mathrm{PO}_{4}-\mathrm{P} \text { (kg ha- } \\
\left.{ }_{1}\right)\end{array}$ & $\begin{array}{c}\mathrm{NO}_{3}-\mathrm{N} \\
(\%)\end{array}$ & $\mathrm{PO}_{4}-\mathrm{P}(\%)$ \\
\hline \multirow[t]{4}{*}{$\mathrm{I}$} & TO & 0 & 0 & $5.39 c$ & $0.17 c$ & & \\
\hline & T1 & 87.9 & 10.9 & $1.40 \mathrm{~b}$ & $0.04 b$ & 1.60 & 0.37 \\
\hline & $\mathrm{T} 2$ & 60.3 & 6.0 & $1.01 \mathrm{~b}$ & $0.03 b$ & 1.70 & 0.50 \\
\hline & T3 & 60.3 & 6.0 & $0.01 a$ & $0 a$ & 0.02 & 0 \\
\hline \multirow[t]{4}{*}{ II } & TO & 0 & 0 & $4.42 b$ & $0.14 c$ & & \\
\hline & $\mathrm{T} 1$ & 60.3 & 6.0 & $2.5 b$ & $0.05 b$ & 4.10 & 0.83 \\
\hline & $\mathrm{T} 2$ & 87.9 & 10.9 & $2.0 \mathrm{~b}$ & $0.04 b$ & 2.20 & 0.37 \\
\hline & T3 & 87.9 & 10.9 & $0.01 a$ & $0 a$ & 0.01 & 0 \\
\hline \multirow[t]{4}{*}{ III } & TO & 0 & 0 & $18.9 d$ & $0.4 c$ & & \\
\hline & $\mathrm{T} 1$ & 87.9 & 10.9 & $4.21 \mathrm{c}$ & $0.09 b$ & 4.80 & 0.83 \\
\hline & $\mathrm{T} 2$ & 38.1 & 2.22 & $2.18 \mathrm{~b}$ & $0.05 b$ & 5.70 & 2.30 \\
\hline & T3 & 38.1 & 2.22 & $0.1 a$ & $0 a$ & 0.27 & 0 \\
\hline
\end{tabular}

\subsubsection{Effects of the treatments on crop growth and yield}

\section{Crop growth and yield}

Maize plant height differed significantly $(P<0.05)$ among the treatments only at site II, in the order $\mathrm{T} 1 \geq \mathrm{T} 3>\mathrm{T} 0=\mathrm{T} 2$ (Table 4.9). Maize development varied among the sites, with plant height following the order $|>| I \mid>I I$. Except at site III, the treatments significantly $(P<0.05)$ affected maize yield, but the effect was different at each site (Table 4.9). At site I, T1 and T3 (1.4 and $1.3 \mathrm{t} \mathrm{ha}^{-1}$, respectively) significantly $(P<0.05)$ increased maize yield relative to TO (0.6 ton ha ${ }^{-1}$ ), with no significant difference between the two or between T2 and T0. 
Maize yield followed the order $\mathrm{T} 3 \geq \mathrm{T} 1>\mathrm{T} 2=\mathrm{T} 0$. At site II, only $\mathrm{T} 1\left(0.8\right.$ ton ha $^{-1}$ ) significantly increased maize yield relative to T0 $\left(0.6\right.$ ton $^{-1}$ ). Maize yield had the order $\mathrm{T} 1>\mathrm{T} 0=\mathrm{T} 3=\mathrm{T} 2$. T1-T3 did not differ significantly from T0 at site III. Mean maize yield was low at all sites in the order I>II>III (Table 4.9).

The treatments significantly affected bean yield at sites I and II but not at site III (Table 4.9). At site I, T1 significantly increased cowpea yield relative to $T 2, T 3$, and $T 0$, nearly doubling the yield. The bean yields at site II were significantly lower (50\% or less) in T2 and T3 than in T0, while the yield in T1 was similar to that in T0. The treatments significantly affected crop biomass at all sites in the 2012 cropping season (Table 4.9). All supplemented treatments at site I significantly increased biomass relative to TO, but only T1 significantly increased biomass at sites II and III.

Table 4.9 Effects of the treatments on maize height, maize yield, bean yield, and crop biomass (dry biomass) at each experimental site for the 2012 growing season. The values are means \pm standard deviations. Different letters indicate significant differences between the treatments $(P<0.05): a<b<c$. See Table 4.2 for treatment descriptions.

\begin{tabular}{|c|c|c|c|c|c|}
\hline Site & Treatment & Maize height $(\mathrm{cm})$ & $\begin{array}{l}\text { Maize yield (kg } \\
\text { ha }^{-1} \text { ) }\end{array}$ & $\begin{array}{c}\text { Bean yield } \\
\left(\mathrm{kg} \mathrm{ha}^{-1}\right)\end{array}$ & $\begin{array}{l}\text { Biomass } \\
\left(\mathrm{kg} \mathrm{ha}^{*}\right)\end{array}$ \\
\hline \multirow[t]{4}{*}{1} & TO & $172 \pm 7.0$ & $625 \pm 110 a$ & $88.3 \pm 11 a$ & $4722 \pm 636 a$ \\
\hline & $\mathrm{T} 1$ & $202 \pm 9.0$ & $1306 \pm 127 b$ & $174 \pm 52 b$ & $6736 \pm 1147 b$ \\
\hline & $\mathrm{T} 2$ & $191 \pm 8.0$ & $930 \pm 122 a$ & $81.7 \pm 10 a$ & $6111 \pm 636 b$ \\
\hline & T3 & $205 \pm 16$ & $1430 \pm 307 b$ & $89.9 \pm 13 a$ & $7778 \pm 1339 b$ \\
\hline \multirow[t]{4}{*}{ II } & TO & $148 \pm 12 a$ & $549 \pm 144 a$ & $458 \pm 155 b$ & $3409 \pm 601 a$ \\
\hline & $\mathrm{T} 1$ & $171 \pm 7.0 \mathrm{~b}$ & $761 \pm 156 b$ & $492 \pm 165 b$ & $4394 \pm 860 \mathrm{~b}$ \\
\hline & $\mathrm{T} 2$ & $151 \pm 10 a$ & $377 \pm 55 a$ & $188 \pm 9.46 a$ & $2719 \pm 402 a$ \\
\hline & T3 & $168 \pm 10 b$ & $478 \pm 122 a$ & $230 \pm 49.8 a$ & $3070 \pm 402 a$ \\
\hline \multirow[t]{4}{*}{ III } & T0 & $163 \pm 12$ & $258 \pm 57$ & $437 \pm 205$ & $2972 \pm 88 a$ \\
\hline & $\mathrm{T} 1$ & $171 \pm 2.0$ & $320 \pm 47$ & $530 \pm 159$ & $3523 \pm 227 b$ \\
\hline & $\mathrm{T} 2$ & $163 \pm 5.0$ & $241 \pm 44$ & $249 \pm 22.9$ & $2193 \pm 76 a$ \\
\hline & T3 & $171 \pm 9.0$ & $236 \pm 34$ & $326 \pm 85.8$ & $2500 \pm 132 a$ \\
\hline
\end{tabular}

"Bean yield is for both feijão pedra and cowpea, except at site I where it is for cowpea only; ${ }^{* *}$ Biomass includes all aboveground material from the maize, feijão pedra, and cowpea plants after harvesting.

\subsubsection{Relationships between the various parameters}

Three principal components (PCs) together explained $89 \%$ of the variance in the data. Parameters such as runoff and soil loss, $\mathrm{NO}_{3}-\mathrm{N}$, and $\mathrm{PO}_{4}-\mathrm{P}$ loss were associated with $\mathrm{PC1}$ (treatment component), which explained $43 \%$ of the variance, while maize yield, crop biomass, rainfall, and slope were associated with PC2 (yield/crop component), which explained $30 \%$ of the variance. Only soil moisture was associated with PC3, which explained $16 \%$ of the variance (Figure 4.6 and Table 4.11 ). 
Table 4.10 Nitrogen $(N)$ and phosphorus $(P)$ content of maize leaves at each experimental site for the 2012 cropping season. Different letters indicate significant differences between the treatments $(P<0.05): a<b<c$. The leaf samples were collected at early maturity.

\begin{tabular}{|c|c|c|c|c|c|c|}
\hline \multirow[t]{2}{*}{ Treatment $^{*}$} & \multicolumn{2}{|c|}{ Site I } & \multicolumn{2}{|c|}{ Site II } & \multicolumn{2}{|c|}{ Site III } \\
\hline & $\begin{array}{c}\mathrm{N}^{* *} \\
\left(\mathrm{~g} \mathrm{~kg}^{-1}\right)\end{array}$ & $\begin{array}{c}P^{* *} \\
\left(\mathrm{~g} \mathrm{~kg}^{-1}\right)\end{array}$ & $\begin{array}{c}\mathrm{N}^{* *} \\
\left(\mathrm{~g} \mathrm{~kg}^{-1}\right)\end{array}$ & $\begin{array}{c}P^{* *} \\
\left(\mathrm{~g} \mathrm{~kg}^{-1}\right)\end{array}$ & $\begin{array}{c}\mathrm{N}^{* *} \\
\left(\mathrm{~g} \mathrm{~kg}^{-1}\right)\end{array}$ & $\begin{array}{c}P^{* *} \\
\left(\mathrm{~g} \mathrm{~kg}^{-1}\right)\end{array}$ \\
\hline T0 & $17.7 \pm 2.55$ & $4.27 \pm 0.97$ & $18.4 \pm 1.42$ & $2.75 \pm 0.134 a$ & $16.8 \pm 3.67$ & $3.20 \pm 0.60$ \\
\hline $\mathrm{T} 1$ & $20.6 \pm 3.79$ & $4.34 \pm 0.39$ & $20.0 \pm 1.89$ & $3.36 \pm 0.5 \mathrm{ab}$ & $18.8 \pm 2.81$ & $3.37 \pm 0.77$ \\
\hline $\mathrm{T} 2$ & $22.5 \pm 4.24$ & $4.63 \pm 0.76$ & $21.7 \pm 3.12$ & $4.30 \pm 0.55 b c$ & $20.5 \pm 2.22$ & $3.43 \pm 1.24$ \\
\hline T3 & $19.6 \pm 1.71$ & $4.37 \pm 0.31$ & $21.5 \pm 2.25$ & $5.13 \pm 0.06 c$ & $21.7 \pm 2.45$ & $2.97 \pm 0.86$ \\
\hline
\end{tabular}

"See Table 4.2 for treatment descriptions. ${ }^{* *}$ Sufficiency range is $25-35 \mathrm{~g} \mathrm{~kg}^{-1}$ for N and 2.5-4.0 $\mathrm{g} \mathrm{kg}^{-1}$ for P

(Modesto et al., 2014).

Table 4.11 Component matrix of the relationships between the parameters and the main components of the principal components analysis.

\begin{tabular}{cccc}
\hline Parameter & \multicolumn{3}{c}{ Component } \\
\cline { 2 - 4 } & $\mathbf{1}$ & $\mathbf{2}$ & $\mathbf{3}$ \\
\hline Treatment & -0.707 & -0.577 & 0.143 \\
Biomass & -0.458 & 0.822 & -0.160 \\
Maize yield & -0.400 & 0.703 & -0.393 \\
Runoff & 0.792 & 0.172 & -0.344 \\
Soil loss & 0.928 & 0.247 & 0.024 \\
Soil moisture & 0.135 & -0.441 & 0.788 \\
Rainfall & -0.517 & 0.697 & 0.457 \\
Total N loss & 0.832 & 0.348 & 0.327 \\
Total P loss & 0.834 & 0.426 & 0.276 \\
Slope & 0.499 & -0.681 & -0.502 \\
\hline
\end{tabular}

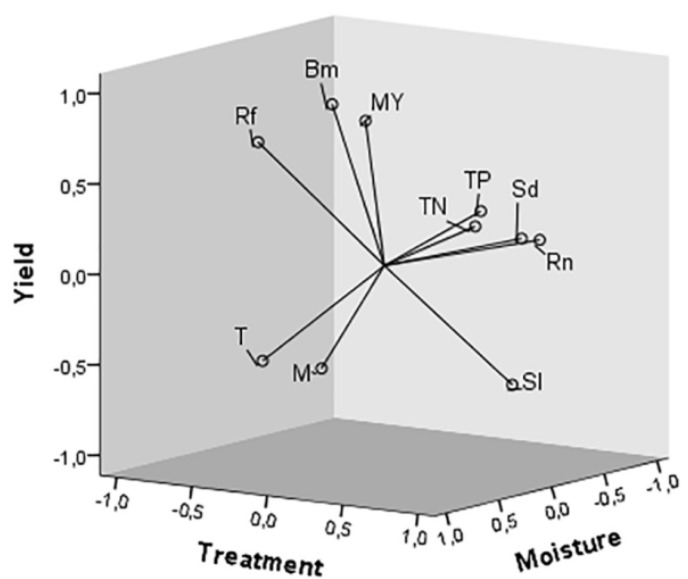

Figure 4.6 Principal components showing the three components extracted from the variables: $T$, treatment; $R f$, rainfall; Bm, biomass; $M Y$, maize yield; $T N$, total $N$ loss; $T P$, total P loss; Rn, runoff; Sd, sediment loss; $S I$, slope; $M$, soil moisture. 
Nutrient status of the maize plants

The application of all three types of organic amendments (compost and animal and green manure) increased the $\mathrm{N}$ contents of the maize leaves relative to the control, but the increases were not statistically significant (Table 4.10). The $\mathrm{N}$ content varied from 16.9 to $22.5 \mathrm{~g} \mathrm{~kg}^{-1}$, and the P content varied from 3.36 to $4.30 \mathrm{~g} \mathrm{~kg}^{-1}$.

Runoff and soil loss were strongly positively correlated $(\alpha=0.001)$ at all sites, with the order of correlation of I (0.800)>II (0.790)>III (0.693). The losses of $\mathrm{NO}_{3}-\mathrm{N}$ and $\mathrm{PO}_{4}-\mathrm{P}$ were strongly positively correlated with the amount of soil lost, which was also highly positively correlated with the runoff. Maize yield and biomass were positively correlated with soil moisture, rainfall, and slope but were not significantly correlated with treatment application or the nutrient parameters.

Both runoff and soil loss were positively correlated with rainfall, total $\mathrm{NO}_{3}-\mathrm{N}$ and $\mathrm{PO}_{4}-\mathrm{P}$ losses, and slope. The correlation coefficients of the nutrient losses, however, were higher with soil loss than with runoff.

\subsection{Discussion}

\subsubsection{Nutrient losses in runoff and eroded soil}

\section{Runoff and soil and nutrient losses}

The annual amounts of runoff and soil loss were generally low for all treatments and sites, with the highest annual runoff and coefficient $\left(20 \mathrm{~L} \mathrm{~m}^{-2}\right)$ in TO at site II and the highest annual soil loss $\left(156 \mathrm{~g} \mathrm{~m}^{-2}\right)$ in TO at site III. These amounts were significantly lower than those reported for 2011 at the same sites (Baptista et al., 2015b) and at other locations in the watershed (Smolikowski et al., 2001). The low runoff and soil loss were due to the short rainy season, with rains of low erosivity during the season. The smallest runoff and largest erosion rates at site III can be attributed to the high soil erodibility associated to the higher silt content in this site than in the others (O'Green et al., 2006).

The nutrient concentrations in the runoff $\left(2.20-4.83 \mathrm{mg} \mathrm{L}^{-1} \mathrm{NO}_{3}-\mathrm{N}\right.$ and $0.02-0.07 \mathrm{mg} \mathrm{L}^{-1}$ $\left.\mathrm{PO}_{4}-\mathrm{P}\right)$ and eroded soil (1.30-8.51 $\mathrm{mg} \mathrm{g}^{-1} \mathrm{NO}_{3}-\mathrm{N}$ and 5.27-18.8 $\left.\mathrm{mg} \mathrm{g}^{-1} \mathrm{PO}_{4}-\mathrm{P}\right)$ were higher than those reported at the plot level in Burkina (Zougmoré et al., 2009) and at the watershed level in Cabo Verde (Tavares, 2010).

The amounts of $\mathrm{NO}_{3}-\mathrm{N}\left(0-18.9 \mathrm{~kg} \mathrm{ha}^{-1}\right)$ lost in runoff and eroded soil, particularly for site III, may have been higher than those in other hilly areas (Ali et al., 2007; Han et al., 2010), 
but total $\mathrm{PO}_{4}-\mathrm{P}\left(0-0.4 \mathrm{~kg} \mathrm{ha}^{-1}\right)$ losses were in similar ranges. All supplemented treatments (T1-T3, but particularly T3) significantly reduced or eliminated runoff and soil loss and the amounts of $\mathrm{NO}_{3}-\mathrm{N}$ and $\mathrm{PO}_{4}-\mathrm{P}$ lost in both runoff and sediments. Similar findings have been reported in Burkina Faso (Zougmoré et al., 2009), Pakistan (Ali, et al., 2007), and China (Han et al., 2010; Xia et al., 2013). Indeed, runoff and water erosion can transport nutrients from the field either dissolved in solution or associated with soil particles, reducing the amount of nutrients available to support crop production (Pimentel et al., 1995; Roose, 2004; Pimentel, 2006).

The absence of a significant effect of the supplemented treatments on nutrient concentrations in both the runoff and sediments, and the positive effect of the treatments in reducing nutrient losses, indicated that the loss of nutrients in each treatment was mainly a function of the amount of runoff and soil loss, as previously reported (Ali et al., 2007; Tiscareno-Lopez et al., 2004; Zougmoré et al., 2009), and was not dependent on the nutrient concentration of the eroded soil and runoff water (Zobisch et al., 1995; Adimassu et al., 2014. This dependence can also account for the large nutrient losses in the control plot, which lost the most soil, and the small nutrient losses in T3, which lost the least amount of soil.

The results indicated that most of the $\mathrm{NO}_{3}-\mathrm{N}$ was lost in the runoff and most of the $\mathrm{PO}_{4}-\mathrm{P}$ was lost in the eroded soil, as also reported by other studies (Ali et al., 2007; Zougmoré et al., 2009; Xia et al., 2013). The higher $\mathrm{PO}_{4}-\mathrm{P}$ losses in the sediments in $\mathrm{T} 1$ (without hedges) compared with $\mathrm{T} 2$ and $\mathrm{T} 3$ (with hedges) indicated that the pigeon-pea hedges contributed to the lower $\mathrm{PO}_{4}-\mathrm{P}$ losses in the sediments. The effectiveness of all supplemented treatments to significantly reduce nutrient losses can be attributed to the organic amendments (compost or animal or green manure) applied to the plots, because their incorporation into the soil can improve aggregate stability and thus reduce $\mathrm{NO}_{3}-\mathrm{N}$ and $\mathrm{PO}_{4}-\mathrm{P}$ losses, as previously reported (Zougmoré et al., 2009). Mulch, as in the T3 plots, can protect soil against the impact of raindrops, decrease runoff velocity, improve the infiltration capacity of the soil, and thus control erosion and nutrient loss (Mando, 1997; Zougmoré et al., 2003; Novara et al., 2013).

\section{Nutrient inputs versus losses}

Nutrient inputs in the supplemented treatments were higher than the losses, but the losses in TO that received no inputs were higher than those in the supplemented treatments, indicating that the nutrients were lost from the original soil, as previously reported (Ali et al., 2007). The partial nutrient balance was positive for all supplemented treatments at all sites, but the balance for the traditional system (T0) may have been low, particularly at sites II and III, which in the medium to long term could lead to nutrient 
depletion, crop nutrient deficiency, and lower yields. Despite the relatively low annual nutrient losses, the combination of a technique to control soil erosion with an organic amendment will contribute to better long-term sustainable land management, because these techniques will decrease soil loss, provide nutrients for better crop productivity, maintain soil fertility, and prevent nutrient depletion (Dass et al., 2011; Wu \& Ma, 2015).

\subsubsection{Effect of the treatments on crop growth and yield}

\section{Crop yields and biomass}

The responses of dryland maize yield to the treatments were clearly inconsistent due to the irregularity of the rainfall, which affected the crop at crucial stages of its development, as has also been reported in earlier studies in Cabo Verde (Querido, 1999; Smolikowski et al., 2001; Varela, 2012). The short and poorly distributed rains during the growing season also contributed to the overall low maize yield at the three sites.

The plots containing pigeon-pea hedges (T2 and T3, at sites II and III) produced a shading effect on the maize plants, hindering the development and yield of the maize after the complete development of the hedges. The yields at site I, which did not contain pigeonpea hedges, supported this finding. The effect of shading may have also masked the performance of the combined treatments, suggesting that the hedges were spaced too closely and/or that the pigeon-pea plants needed to be managed to eliminate the shading on the maize crop. Our results corroborated those in another study with hedges of $L$. leucocephala in Burkina Faso (Zougmoré et al., 2003). Despite the positive effects of T2 and T3 on maize yield in some cases, the efficiency of the pigeon-pea hedges and mulch on maize yield was not conclusive for the cropping season studied. The ability of mulch combined with L. leucocephala hedges to improve the use of water resources by grain crops in semi-arid regions has been questioned (Smolikowski et al., 2001).

The high performance of T1, which consistently increased crop yield at all sites, showed the positive effect of both manure and compost combined with a soil surfactant, even though the plant nutrient content did not reach the sufficiency level. Thus, T1 can be considered the best treatment for flatter areas with deeper soils, considering mainly crop yield. However, on steep hillsides with shallow soils T3 will be the best treatment in order to prevent further land degradation due to runoff, soil erosion and nutrient loss. Given the efficiency of T3 in reducing runoff, erosion and nutrient loss (Table 4.7), it is the best treatment for the steep hillsides to guarantee the sustainability of soil management, as long as the pigeon-pea hedges are well managed to avoid shading. 
Earlier studies in Cabo Verde (Baptista, 2000, 2003) reported a significant increase in maize yield with the application of animal manure and a positive effect of Leucaena prunings as an $\mathrm{N}$ source for dryland maize production. In the absence of inorganic $\mathrm{N}$ fertiliser, however, only very high doses $\left(6 \mathrm{t} \mathrm{ha}^{-1}\right)$ of Leucaena prunings significantly increased yield. Other studies (Mittal et al., 1992; Sharma \& Behera, 2010) have also reported positive effects of Leucaena leaf biomass on the $\mathrm{N}$ economy and productivity of maize.

The availability of Leucaena biomass in Cabo Verde depends on the regularity of rainfall, so large quantities of material may not be available for green manuring. Animal manure is also not plentiful, so composting crop residues with animal and green manures would be a more sustainable solution for supplying nutrients to dryland maize.

The yield of pigeon-pea from the hedges was not included in the yield analysis. The crop, though, is high yielding, and both green and dry grains have high nutritional and economic value and are well appreciated as human food. If pigeon-pea biomass from the hedges (T2 and T3 at sites II and II) had been included, our biomass values would have been significantly higher for these treatments. Pigeon-pea biomass would be an added value and incentive for the farmers because it is widely used for animal feed (Tavares et al., 2013). Pigeon-peas are a leguminous, high-yielding crop (5-12 t ha ${ }^{-1}$ dry biomass) with a relatively high $\mathrm{N}$ content (24-29 $\mathrm{g} \mathrm{kg}^{-1}$ ), contributing to improve $\mathrm{N}$ budget when incorporated into maize-based cropping systems (Adu-Gyamfi et al., 2007). Pigeon-pea prunings can also be used as soil cover to protect the soil from erosion and to improve soil fertility.

\section{Plant nutrient status}

The $\mathrm{N}$ content of the plant tissues was below the sufficiency level (Steinhilber \& Salak, 2010) in all treatments at all sites, but the P content was at or above the sufficiency level in all treatments at all sites. Maize is a nutrient-demanding staple crop, so symptoms of deficiency appear and grain yield and quality decline when $\mathrm{N}$ levels drop below the sufficiency range (Modesto et al., 2014). $\mathrm{N}$ is a limiting nutrient in dryland maize in Cabo Verde (INIDA, 1997), and deficiency symptoms are widespread on the hillsides. In fact, symptoms of $\mathrm{N}$ deficiency were registered at all sites in both seasons.

The absence of a significant response to the application of the organic nutrient sources may have been due to the low $\mathrm{N}$ content of the compost $\left(22 \mathrm{~g} \mathrm{~N} \mathrm{~kg}^{-1}\right)$, animal manure (23 $\left.\mathrm{g} \mathrm{N} \mathrm{kg}^{-1}\right)$, and green manure ( $36 \mathrm{~g} \mathrm{~N} \mathrm{~kg}^{-1}$ ) applied to the soil. In such case, higher rates of organic amendments would be required to supply adequate nutrients to the maize plants. For soils low in $\mathrm{N}$ and $\mathrm{P}$, application rates of 100 and $40 \mathrm{~kg} \mathrm{ha}^{-1}$ of $\mathrm{N}$ and $\mathrm{P}$, respectively, 
have been reported for optimum yields of local varieties of maize (Kogbe \& Adediran, 2003; Khan et al., 2014). Another possibility for the absence of a significant response could be a slow rate of $\mathrm{N}$ mineralisation in the amendments, particularly the manure, which would reduce the amount of $\mathrm{N}$ available to the crops during the cropping season (Baptista, 1996). Increasing the amount of organic material, particularly the green and animal manures, to satisfy the $\mathrm{N}$ and $\mathrm{P}$ requirements may not be feasible due to low availability and to the poor economic conditions of the farmers.

\subsubsection{Relationships among the various parameters}

The treatment component was responsible for $43 \%$ of the variance in the data and was strongly associated with most parameters related to the nutrient losses in the runoff and sediments, confirming the positive effect of the techniques of land management on nutrient losses. Soil loss increased with increasing runoff, and nutrient losses increased with the amounts of runoff and soil losses. This indicates that the factors influencing runoff and soil loss (i.e. soil cover, vegetation runoff hedges, rain erosivity, and slope), as previously reported (Araya \& Stroosnijder, 2010; Araya et al., 2011; Baptista et al., 2015b), also influenced the nutrient losses (Ali et al., 2007; Zougmoré et al., 2009). These findings could account for the high effectiveness of the treatment containing mulch, pigeon-pea hedges, and an organic amendment (T3) in reducing nutrient losses associated with runoff and erosion. The stronger correlation between nutrient losses and soil loss compared to runoff indicated higher $\mathrm{NO}_{3}-\mathrm{N}$ and $\mathrm{PO}_{4}-\mathrm{P}$ losses in the eroded sediments at all sites.

Maize and biomass yields, the second most important component and responsible for $30 \%$ of the variance in the data, were not significantly correlated with treatment application or the nutrient losses but were positively correlated with soil moisture and rainfall. This lack of a generalised effect of the supplemented treatments on both maize yield and biomass was highlighted in section 4.2 and was due mainly to the variability of rainfall and the low soil moistures in some of the treatments during critical periods of the cropping season. For example, T2 and T3 at site II contained pigeon-peas and thus had higher plant biomasses than did T0 and T1, and the competition for water was greater, which together with the low water-retention capacity of the sandy loam soil could account for the low moisture content. At site III, however, as the plants reached full development and rainfall and moisture was more abundant, $\mathrm{T} 2$ and $\mathrm{T} 3$ registered higher soil-moisture contents than did TO and T1, despite the high use of water by the abundant biomass, perhaps due to the high water-holding capacity of the soil. 
The absence of a significant correlation between the crop parameters (maize, bean, and biomass yields) and the nutrient losses may have been due to the low losses, not affecting yield or plant development. The strong correlation between the nutrient losses and rainfall at each site, though, was an indication of the importance of a regularly distributed rainfall for providing moisture to the crops throughout the growing season; soil moisture was responsible for $16 \%$ of the variability in the data. The difference in soil-moisture content between the sites was due to the different soil textures, which influenced infiltration and the capacity of the soil to retain water in the order silty clay loam>loam>sandy loam.

\subsection{Conclusions}

This study evaluated the effects of selected sustainable land management techniques on nutrient losses in runoff and sediments and on crop yield. The following conclusions can be drawn:

The combination of an organic amendment with soil surfactant (T1) could be considered the best treatment for flatter areas with deeper soils less affected by soil erosion and setting the focus on increased crop yield.

The combination of crop-residue mulch with organic amendment and runoff hedges (T3) could be the best treatment to prevent further land degradation due to runoff, soil erosion and nutrient loss on steep hillsides with shallower soils, as long as the pigeon-pea hedges are well managed to guarantee higher maize yield.

Further research should focus on long-term field trials to include a wider range of rainfall conditions and should test different rates of organic amendments. This study aimed to help smallholder subsistence farmers, so an evaluation of the cost-effectiveness of the selected technologies will be crucial in establishing sustainable options under semi-arid hillside conditions and in determining their biophysical and socio-economic applicability at a wider scale.

Effective farmer involvement through the establishment of demonstration plots and farmer education and awareness of the need to prevent the degradation of soil fertility for sustainable dryland yields will be essential to foster the adoption and successful implementation of the selected strategies. 
Strategies of sustainable land management that increase the use of rainwater, prevent the degradation of soil fertility, and potentially increase sustainable dryland yields should be promoted and implemented on the semi-arid hillsides in Cabo Verde. 


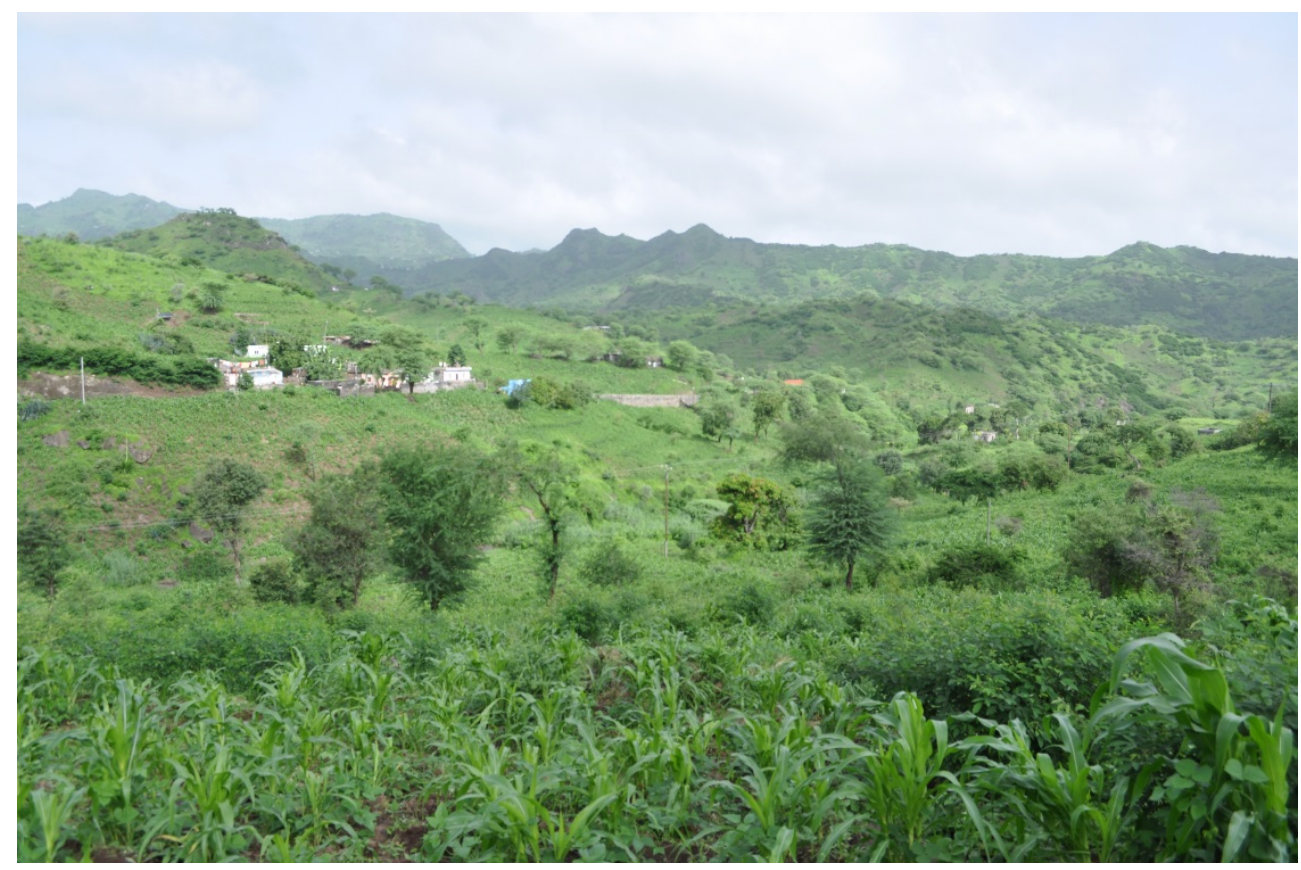




\section{Assessing the biophysical impact and financial viability of soil management technologies under variable climate in Cabo Verde drylands: the PESERA-DESMICE approach}

Field trials have demonstrated the potential of soil conservation technologies but have also shown significant spatial-temporal yield variability. This study considers the PESERADESMICE modelling approach to capture a greater range of climatic conditions to assess the potential effect of an improved agricultural management practice emerged from field trials as a promising strategy for enhancing food security and reducing soil and land degradation. The model considers the biophysical and socio-economic benefits of the improved soil conservation technique (T3) - residue mulch combined with pigeon-pea hedges and an organic amendment, against a local baseline practice (TO). The historic rainfall statistics and 50-year rainfall realizations provide a unique time-series of rainfall and an envelope of the potential crop yield. Envelopes of potential biomass production help express the agricultural risk associated with climate variability and the potential of the conservation measures to absorb the risk, highlighting the uncertainty of a given crop yield being achieved in any particular year. T3 elevates yield under both sub-humid and semi-arid climates with greater security for sub-humid areas even though risk of crop failure still exists. The technology offered good potential to increase yields by $20 \%$ in $42 \%$ of the area and reduce erosion by $8.6-\mathrm{Mg} \mathrm{ha}^{-1}$, but in terms of cost effectiveness, it might be prohibitively expensive for farmers lacking inputs. The findings can enable the assessment of policy options at larger scale or influence adoption of improved conservation measures under the climatic variability of the Cabo Verde drylands and resilience to future climate change.

This chapter is accepted for publication as:

Baptista, I., Irvine, B., Fleskens, L., Geissen, V., Ritsema, C.J. 2015. Assessing the biophysical impact and financial viability of soil management technologies under variable climate in Cabo Verde drylands: the PESERA-DESMICE approach. Land Degradation \& Development. 


\subsection{Introduction}

Land degradation persists as one of the most pressing environmental concerns with important consequences for sustainability at various levels through complex links with food production, poverty and climate change (Stringer et al., 2014, Fleskens et al., 2014). Soil erosion by water is recognized as an important worldwide driver of land degradation with consequences for the maintenance of soil fertility, sustainable dryland crop yields (Lal, 1995; Geissen et al., 2007; Kirkby et al., 2008; Muzinguzi et al., 2015), water availability (Araya et al., 2011), affecting food production, fuelwood, income and housing (Tesfaye et al., 2015). By removing the most fertile topsoil, erosion reduces soil productivity, potentially leading to a progressive loss of farmland where soils are shallow or conducting to desertification in more vulnerable areas (Xu et al., 2014; Baptista et al., 2015b; Xie et al., 2015).

In semi-arid and arid areas, rainfall variability, the occurrence of extreme drought and inappropriate historical land management practices have been recognized as contributing to serious environmental impact (Hessel et al., 2009; Baptista \& Tavares, 2011; Ferreira et al., 2012; Baptista et al. 2015a). For example, in Cabo Verde, a Sahelian country severely affected by land degradation and desertification (Ferreira et al., 2013; Tavares et al., 2015), rainfall in 2014 was 65 \% lower than the year prior. Consequently, Cabo Verde produced just $1000 \mathrm{Mg}$ of corn in 2014 (FAO, 2015), the lowest output ever in the history of the country which has caused a considerable shortage of livestock feed. This significant impact of the 2014 drought occurred despite enormous investment in soil conservation, which has become visible throughout the Cabo Verde landscape (Tavares et al., 2014; Baptista et al., 2015a). However, the biophysical and socioeconomic impacts of the conservation measures have been poorly assessed and, in particular, their performance under variable climatic conditions has not been documented. In recent years, a concerted approach based on Schwilch et al. (2012) has started to address this gap by documenting stakeholder consultations and carrying out field trials for selected sustainable land management (SLM) technologies.

SLM technologies are practical measures to prevent and/or decrease and/or reverse the effects of land degradation on land resources (i.e. soil and water) extending over defined spatial, temporal, and socio-cultural boundaries, and maintain and improve land productivity, water saving and use efficiency (Fleskens et al., 2014; Baptista et al., 2015b). Successful SLM technologies may support the rehabilitation of degraded land or conservation, helping to harness benefits over larger areas (Stringer et al., 2014). Yet, scaling-up adoption of SLM technologies beyond initial spatial, temporal and socio-cultural boundaries is challenging, often with low adoption of technologies due to design failures 
and lack of an approach that fully recognizes land managers' interests and socioeconomic dynamics (Tenge et al., 2005; 2007). Comprehensive identification and evaluation of SLM technologies are crucial to assess the applicability of promising technologies, their cost and the likely impact they will bring. Close stakeholder involvement in selecting the technologies to evaluate is vital (Schwilch et al., 2009; Tavares et al., 2014; Hessel et al., 2014; Baptista et al., 2015a). Model evaluation of the selected technologies additionally informs stakeholders regarding the spatial extent and regional impact of the technologies being considered; thus enhancing their understanding of the technology. Fleskens et al. (2014) highlight that this principle underpins the integrated PESERA-DESMICE (PanEuropean Soil Erosion Assessment - Desertification Mitigation Cost Effectiveness) approach developed as part of the DESIRE project.

The PESERA-DESMICE modeling approach offers a methodology to assess the biophysical and socio-economic benefits of SLM technologies against a local baseline condition (Fleskens et al., 2014; Stringer et al., 2014). PESERA is a process-based erosion prediction model, which explicitly considers climate variability and can be adapted to consider SLM strategies. DESMICE is an economic model that operates through spatial cost-benefit analysis (CBA), considering the suitability of the conservation measures in terms of environmental conditions and market access. The modeling approach departs from the assumption that for SLM technologies to get adopted they need to be financially attractive to land managers in terms of cost reduction and /or benefit enhancement (Fleskens et al., 2014).

Although biophysical factors and land-use influence soil erosion, the results from plot studies typically indicate the benefits of adopted SLM measures. The aim of this paper is to appraise the applicability of the PESERA-DESMICE modelling approach to extend biophysical and economic benefits of a previously selected promising SLM technology (Baptista et al., 2015b; 2015c) across typical field conditions in the Ribeira Seca catchment, where the SLM had been tested, and over the whole Santiago Island under variable climatic conditions. The rainfall time series for modelling are generated from the distribution of historical data and provide the opportunity to explore a full range of climate variability beyond the period of the trials. 


\subsection{Methods}

\subsubsection{Study site}

The PESERA-DESMICE model application has been based on outcomes from a two-year field experiment carried out with stakeholder participation in three sites (São Jorge, site I; Serrado, site II; and Órgãos Pequenos, site III) in the Ribeira Seca watershed (RSW), which is the largest watershed on Santiago, the main agricultural island of Cabo Verde (Baptista et al., 2015a). The RSW has a drainage surface of approximately $72 \mathrm{~km}^{2}$, is located on the east-central side of the Santiago Island $\left(991 \mathrm{~km}^{2}\right.$ ), between latitude $15^{\circ} 07^{\prime} 40^{\prime \prime} \mathrm{W}$ and longitude $23^{\circ} 32^{\prime} 05^{\prime \prime} \mathrm{W}$ (Figure 5.1) and extends across four agro-ecological zones of the Cabo Verde classification: semi-arid (49\%), arid (20\%), sub-humid (20\%) and humid (11\%) (Diniz \& Matos, 1986).

A

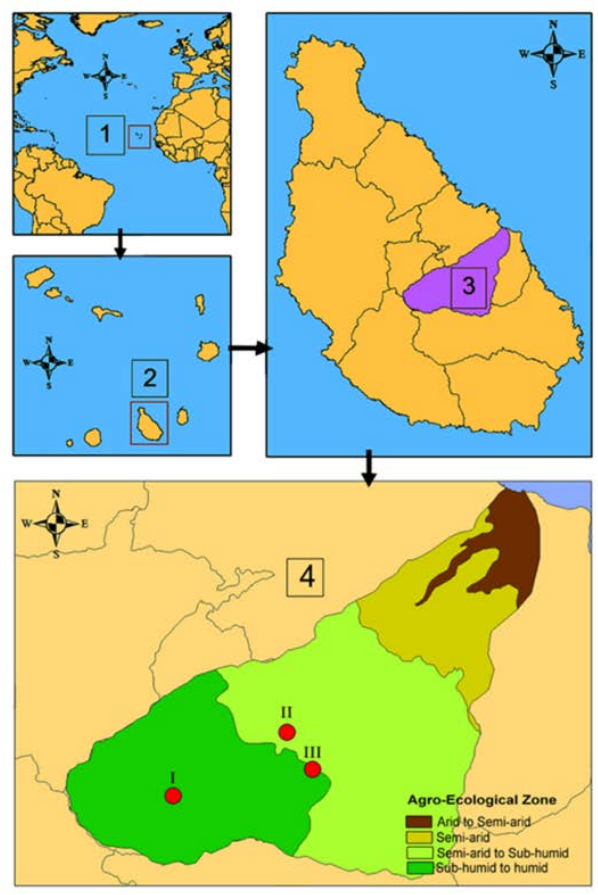

B
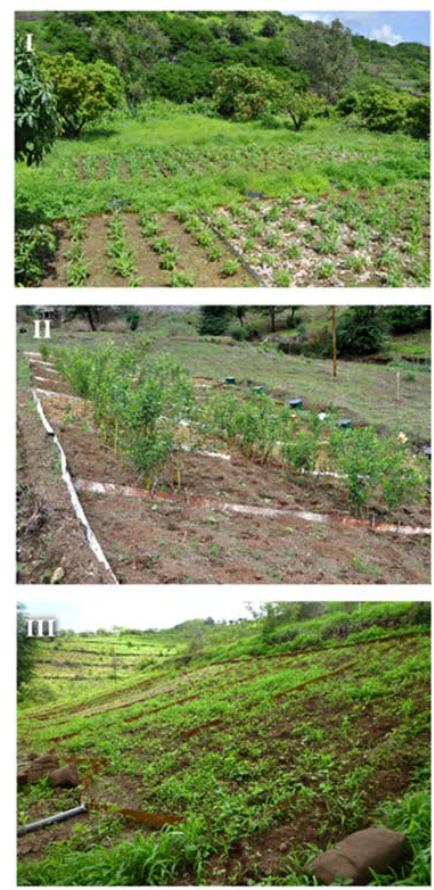

Figure 5.1 Location of the experimental sites within the Ribeira Seca Watershed, Santiago Island (the study site) and Cabo Verde (A) and field aspects of experimental sites at I, II and III (B). Figure 5.1A, adapted from Baptista et al. (2015b). 
The climate of the RSW, as well as that of the Santiago Island, is characterised by a unimodal rainfall regime, with a short (3-4 month) humid season (July-October) and a long (8-9 month) dry season (November-June). Mean annual rainfall is extremely heterogeneous and has an irregular spatiotemporal distribution, varying from $<200 \mathrm{~mm}$ in the downstream section of the watershed to $650 \mathrm{~mm}$ upstream. The 30-year (1980-2010) mean annual rainfall was 437, 300, and $310 \mathrm{~mm}$ at experimental sites I, II, and III, respectively, with most of the rain falling in August and September (INMG, 2010). The topography is rugged and predominant land use is rainfed (i.e. dryland) agriculture, particularly of the staple crops (maize and beans) and groundnut, occupying $>83 \%$ of the area (see Figure 2.3 for land use map). The remaining area is used for: irrigated crops (sugarcane, fruits, vegetables, cassava and sweet potato) $5 \%$, forest $4 \%$, rock outcrops $1 \%$ and $7 \%$ are built environment. Livestock keeping is an important activity in the watershed and in the country in general as most family farmers own animals that often graze freely. In 2013, Cabo Verde had 22000 cattle, 1117000 chickens, 190000 goats, 85000 pigs, and 12000 sheep (FAO, 2013).

Over a two-year period, (2011 - 2012) study plots representing a baseline scenario (T0) and three SLM scenarios (T1-T3) were monitored at the three sites and T3 revealed a promising SLM technology for the steep slopes. Full details of the field study are presented in Baptista et al. (2015b). The baseline scenario (T0) represented a traditional maize/bean intercropping system with no input or conservation measure. The SLM scenario (T3) trialed represented a combination of mulch (4 ton $\mathrm{ha}^{-1}$ of crop residue) and organic fertilizers (i.e. 4 ton $\mathrm{ha}^{-1}$ of compost at site I, 4 ton ha ${ }^{-1}$ of animal manure at site II, and 1 ton ha ${ }^{-1}$ Leucaena leucocephala prunings at site III). In addition, in T3 pigeon-pea hedges were planted cross-slope at 3-meter intervals.

\subsubsection{PESERA model background}

The Pan European Erosion Risk Assessment (PESERA) model provides an objective, physically based and spatially explicit methodology to consider land degradation (Kirkby et al., 2008). Spatial applications at the continental scale at $1 \mathrm{~km}$ resolution and at $100 \mathrm{~m}$ resolution at regional scale allow detailed observed data to be placed in the broader spatial context. As rainfall variability and the occurrence of drought are key issues in food security and land degradation in Cabo Verde consideration is also given to time series analysis at representative points to consider the probability of achieving a defined yield under baseline conditions (TO) and the SLM scenario (T3). Simulated time series generated from historical climate statistics are run repeatedly for each treatment to produce a probability distribution of yield, runoff and erosion. This approach aims to 
capture a representative picture of the rainfall variability observed on the island. Field observations and measurements enable a conceptual understanding of the SLM technology, which informs model adaptations. Through the comparison between the response of the treatments TO and T3 to the variable rainfall, PESERA-DESMICE offers a methodology to compare the benefits of an adapted conservation scenario against a baseline scenario assessment. PESERA provides this comparison through a series of monthly estimates of biomass (productivity), runoff and erosion for T0 and T3. The core of the PESERA model (for both spatial and point applications) is the water balance which partitions precipitation into interception losses, evapotranspiration (from the vegetation canopy and bare ground), overland flow, runoff and infiltration (Figure 5.2, Irvine \& Kosmas, 2003). The rainfall is partitioned such that soil water remains available for plant growth after overland flow is conveyed (Kirkby et al 2008; Esteves et al., 2012). Transpiration is controlled by potential evapotranspiration and the availability of soil water. Soil organic matter contributes to the runoff threshold and infiltration capacity of the soil. Soil organic matter is built through in situ leaf fall and the addition of mulch. The organic matter decomposes as a function of temperature.

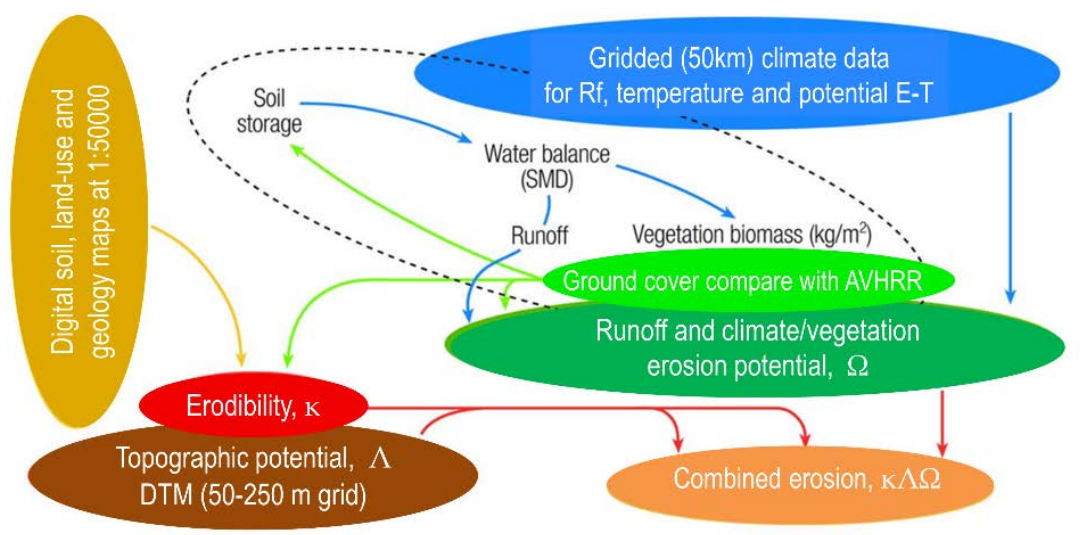

Figure 5.2 PESERA model: partitioning of rainfall (after Irvine \& Kosmas, 2003)

The PESERA model is first run to equilibrium to estimate initial or average conditions before the time-series model is executed. The equilibrium conditions are achieved by running the model with monthly climate statistics derived from the frequency distribution of observed daily rainfall totals. Daily rainfall data is used, as it is more readily available than finer temporal rainfall data even though it is appreciated that the finer storm detail is that which generates most overland flow and erosion. 


\subsubsection{DESMICE model background}

The Desertification Mitigation Cost-Effectiveness (DESMICE) model (Fleskens et al., 2009; 2014) essentially performs a spatially-explicit financial cost-benefit (in terms of long term investments) or gross margin (in terms of annually repeated measures) analysis of SLM technologies. DESMICE evaluates the applicability limitations and inventories the spatial variation in the investment and maintenance costs involved for a pre-selected portfolio of technologies. The effects of the implementation of the SLM technologies (here the T3 scenario) relative to the without situation (TO scenario) are subsequently assessed and valuated in monetary terms. DESMICE consists of a number of steps. First, an analysis is made where a SLM option can in principle be applied based on biophysical factors such as soil depth, slope, landform and land use. The output of this step is a map showing applicability in a dichotomous fashion. A subsequent step assesses investment costs based on environmental factors (i.e. slope) and socio-economic factors (i.e. distance to market) in a spatially explicit way. It allows defining for each cost item the location of source areas (markets) and transportation costs assuming the cheapest transport path, either through a (road) infrastructure network or over a cost surface. Next, in case of assessing multiple SLM options, a common time horizon is set, which in the case of T3 was set at 1 year. Costs and benefits are subsequently assessed including production output (yield $x$ value) realized with the technology, costs of implementing the technology and land use associated with it, and production output and costs of the land use in the without case (TO). Production output is derived from the PESERA model output of biomass yield. Again, benefits and costs may vary in both space and time. The annual cash flows thus established are used either in a financial cost-benefit analysis or, as in this study, gross margin analysis. For each grid cell, one of the following three possible outcomes will apply for assessment of an SLM option: if the gross margin is positive, the technology is deemed viable; if the gross margin is negative, the investment is not financially attractive; or the technology is not applicable in the area. Finally, per unit and aggregate cost-effectiveness indicators can be calculated, i.e. the cost per unit of soil conserved (as simulated by PESERA) by implementing an SLM option (Fleskens et al., 2014).

\subsubsection{Model Application}

\section{Rainfall data}

Climate variability and agricultural practice have been identified as drivers of land degradation in Cabo Verde (Tavares et al., 2014; Baptista et al., 2015a). T0 and T3 consider possible management options while rainfall records provide the basis for generating simulated time-series. These time series have been derived from rainfall data obtained 
from two locations, one (São Jorge) representing sub-humid and the other (Ponto Ferro) semi-arid conditions. The simulated time series are generated directly from the observed variability in the rainfall data (mean monthly rainfall, mean rain per rain day and coefficient of variation in rain per rain day), as the future rainfall predictions for Cabo Verde do not indicate a significant trend (McSweeney et al., 2010). The records extend beyond the two-year period of the field trials and, as such, they can be used to put the experimental rainfall in a wider context by considering frequency of the events experienced during the trials.

Rainfall frequency is estimated from the rainfall records at São Jorge as this station is more representative of the study site. The record covers the period $1983-2007$ (Annex 1). The return period of a given rainfall is estimated by fitting a Gumbel Extreme Value distribution to the observed annual rainfall totals and monthly values. Annual rainfall totals and monthly values are plotted for the duration of the record against a reduced variate ' $y$ ' (here $y=-\ln \left(\frac{r}{n-1}\right)$ ) which describes the probability on a linear scale. The Gumbel Extreme Value distribution estimates the probability of a given event based on the observed mean and variance. This allows the observed event of the two-year field trial to be put in context with the extended rainfall record.

\section{Adapted Model}

Field observations inform the conceptual model for the SLM scenario (T3). A key element considered in the T3 scenario is the improved soil condition through the application of mulch, compost, animal and green manure in soil pits. Manure and mulch are added directly to the soil humus and above ground biomass residue respectively. In the adapted model, this impacts directly on the soil water storage capacity. Soil pits have previously been considered in the modelling of in-situ water harvesting technologies (Lebel et al., 2015). Although the benefits of pits have been highlighted, the application of organic matter is a much more significant component of the hydrological equilibrium. Several studies (Zougmoré et al., 2003; Sawadogo et al., 2008; Lebel et al., 2015) highlight that soil pits alone have little benefit, however, when combined with compost the soil water available to plant growth increases. A number of additional benefits of pits are not readily modelled such as increasing sediment-trapping efficiency, reducing the removal of seed and soil organic matter. Further, soil water available to plants is elevated as the infiltration is reduced, allowing greater soil water retention time

\section{Time series application}

As way of validation, the PESERA baseline model and the adapted model were run against a single 50-year simulated rainfall time-series for the three study sites. Cumulative runoff and erosion are plotted for T0 and T3 (Annex 2a-b). Over the 50-year simulation, the 
reduction in average annual runoff and erosion is of the same magnitude as the observed site data (Baptista et al., 2015b). Extrapolating the experimental data beyond the plot scale requires further data at increasing scales to account for the complexity of scaling between plot area and PESERA hillslope application. However, the magnitude and direction of the observed change remains of greater value and interest when considering spatial applications.

\section{Spatial Application}

Applicability of the SLM scenario (T3) confined to areas under rainfed cropping. GLOBCOV data for Santiago Island (Bontemps et al., 2011) defined these areas. Slope also imposed further limitation on applicability. SRTM90 digital elevation data provided slope maps of the island, and land with slope $>45 \%$ was considered too steep to apply the SLM technology.

Table 5.1 Cost of inputs and produce of the conventional (TO) and improved (T3) soil management scenarios.

\begin{tabular}{|c|c|c|c|c|c|c|}
\hline \multirow[b]{2}{*}{ Item } & \multicolumn{3}{|c|}{ Scenario T0 } & \multicolumn{3}{|c|}{ Scenario T3 } \\
\hline & \# of units & $\begin{array}{c}\text { unit price } \\
\left(^{(E C V)}\right)^{* *}\end{array}$ & $\begin{array}{c}\text { total cost } \\
\text { (ECV) }\end{array}$ & \# of units & $\begin{array}{c}\text { unit price } \\
\text { (ECV) }\end{array}$ & $\begin{array}{c}\text { total cost } \\
\text { (ECV) }\end{array}$ \\
\hline Labour (man days/ha) & 85 & 800 & 68000 & 100 & 800 & 80000 \\
\hline \multicolumn{7}{|l|}{ Seeds } \\
\hline maize $\left(\mathrm{kg} \cdot \mathrm{ha}^{-1}\right)$ & 12 & 100 & 1200 & 12 & 100 & 1200 \\
\hline beans $\left(\mathrm{kg} \cdot \mathrm{ha}^{-1}\right)$ & 12 & 160 & 1920 & 12 & 160 & 1920 \\
\hline pigeon pea (kg.ha $\left.{ }^{-1}\right)$ & 0 & & 0 & 5 & 200 & 1000 \\
\hline \multicolumn{7}{|l|}{ Organic amendments Site I } \\
\hline Crop residue $\left(\mathrm{kg} \cdot \mathrm{ha}^{-1}\right)^{*}$ & 0 & & 0 & 4000 & 6 & 24000 \\
\hline compost $\left(\mathrm{kg} \cdot \mathrm{ha}^{-1}\right)$ & 0 & & 0 & 4000 & 8 & 32000 \\
\hline \multicolumn{7}{|l|}{ Organic amendments Site II } \\
\hline Crop residue $\left(\mathrm{kg} \cdot \mathrm{ha}^{-1}\right)^{*}$ & 0 & & 0 & 4000 & 6 & 24000 \\
\hline Animal manure $\left(\mathrm{kg} \cdot \mathrm{ha}^{-1}\right)^{*}$ & 0 & & 0 & 4000 & 6 & 24000 \\
\hline \multicolumn{7}{|l|}{ Organic amendments Site III } \\
\hline Crop residue $\left(\mathrm{kg} \cdot \mathrm{ha}^{-1}\right)^{*}$ & 0 & & 0 & 4000 & 6 & 24000 \\
\hline green manure $\left(\mathrm{kg} \cdot \mathrm{ha}^{-1}\right)$ & 0 & & 0 & 1000 & & 0 \\
\hline \multicolumn{7}{|l|}{ Transportation (ECV ha ${ }^{-1}$ ) } \\
\hline Products to local market & 1 & 1000 & 1000 & 1 & 1000 & 1000 \\
\hline Materials to the field ${ }^{*}$ & 0 & 0 & 0 & 1 & 4000 & 4000 \\
\hline
\end{tabular}

Costs depending on local availability of inputs and need for transportation. ${ }^{* *}$ (Cabo-Verdean Escudos). Source: own experimental data, local price information. 


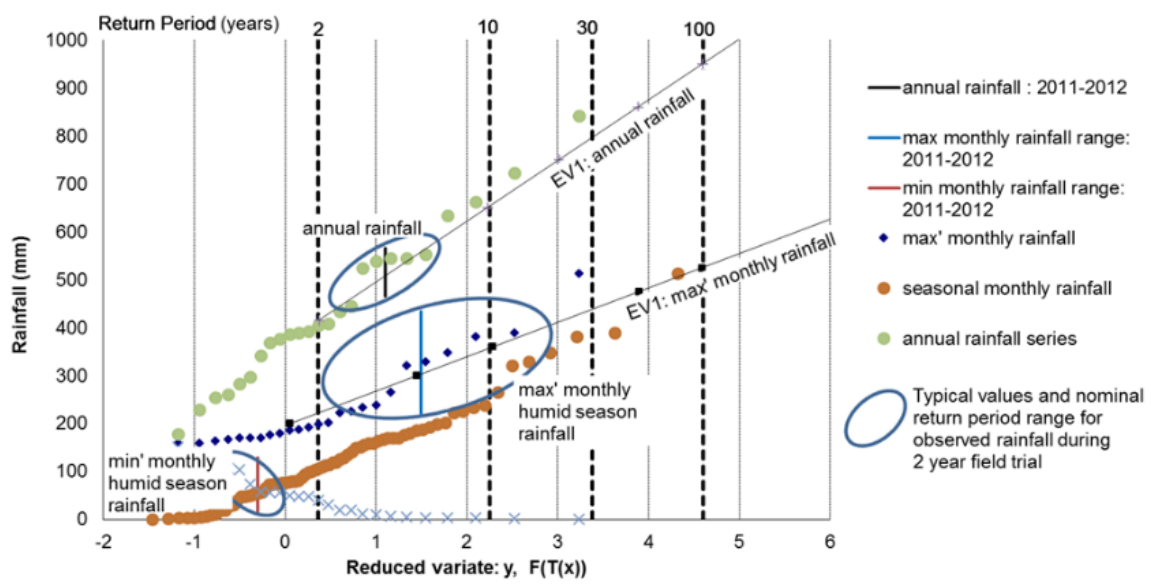

Figure 5.3 Gumbel Extreme Value Estimates; derived from the probability distribution of observed rainfall (plotted as a linear reduced variate value).

Experimental data included estimates of the costs of inputs and produce (Table 5.1). From variations between experimental sites, it was estimated that $20 \%$ of cost levels was due to differences in accessibility, expressed as the distance between field and road. The island's main road network was taken from the gROADSv1 dataset (CIESIN/ITOS, 2013) and used to map variable transport costs based on Euclidian distance to the nearest road. For example, transport costs in Site I amounted to $4000 \mathrm{ECV}$; the site is at $500 \mathrm{~m}$ distance to road, so transport costs of the 4 ton crop residues amount to $0.2 * 4000 / 500=1.6 \mathrm{ECV}$ per meter, or $0.4 \mathrm{ECV}$ per ton per meter. Based on experimental yield data (Baptista et al., $2015 \mathrm{~b})$, biomass partitioning was assumed as follows: $33 \%$ of biomass is produce $(50 \%$ maize, $50 \%$ beans, at average price $130 \mathrm{ECV} / \mathrm{kg}$ ) and $67 \%$ crop residues valued at 6 $\mathrm{ECV} / \mathrm{kg}$.

Soil type and depth are poorly defined at the available spatial resolution for Santiago Island. Available data classifies the majority of the island into one category and depth, where both are seemingly independent of landscape characteristics. However, it is noted from the study plots that biomass growth before and after mitigation may be more sensitive to land management practice and inputs rather than typical soil parameters. This observation therefore justifies the potential value of the spatial assessment based on available data. For the upscaling, climate data is distributed according to annual rainfall totals. However, rainfall variability is considered relative to the two points considered (São Jorge and Ponto Ferro). Mean erosion rates and crop potential are estimated under the rainfall time series derived from the observed climate data from these two stations. 
Input data for DESMICE, average and standard deviation of biomass yield, was derived from a regression analysis of the probability maps of exceedance of nominal biomass yield. Parabolic trend lines were fitted through probabilities of having 0 (always $100 \%$ probability), 800 and $1200 \mathrm{~kg} /$ ha biomass (PESERA). $P_{50}$ values of biomass were taken to inform spatial financial viability assessment. Fluctuating biomass rasters were created using random normal raster creation with probability distribution details specific for T0 and T3. Random rasters were created independently for T0 and T3 to mimic variability due to a range of conditions, but the direction of variability was kept equal (i.e. positive and negative deviances coincide for both treatments).

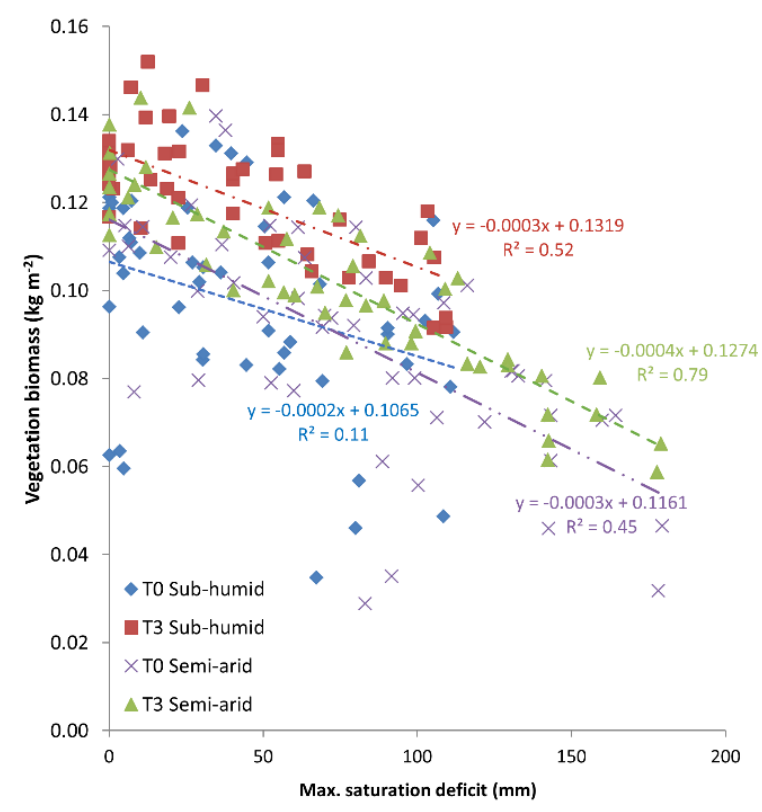

Figure 5.4 Simulated biomass from treatments TO and T3 under sub-humid and semi-arid conditions. Treatment T3 elevates yield under both sub-humid and semi-arid climates, although risk of crop failure still exists.

\subsection{Results}

\subsubsection{Rainfall magnitude and frequency}

Monthly and annual rainfall totals were plotted on a probability scale (Figure 5.3). The observed annual rainfall range of 2011-2012 (vertical black line) shows a return frequency 
range of 1 in 2 years to 1 in 5 years. The observed maximum monthly rainfall range (20112012) shows a return period from 1 in 2 years and 1 in 30 years relative to the long-term records. Records do not suggest significantly unusual dry periods but do indicate a significant monthly rainfall bias. Simulated 50 -year time series generate rainfall variability that allows the impact of rainfall to be extended. Multiple simulations allow this to be extended further typically covering annual rainfall in the range between $200-1000 \mathrm{~mm}$.
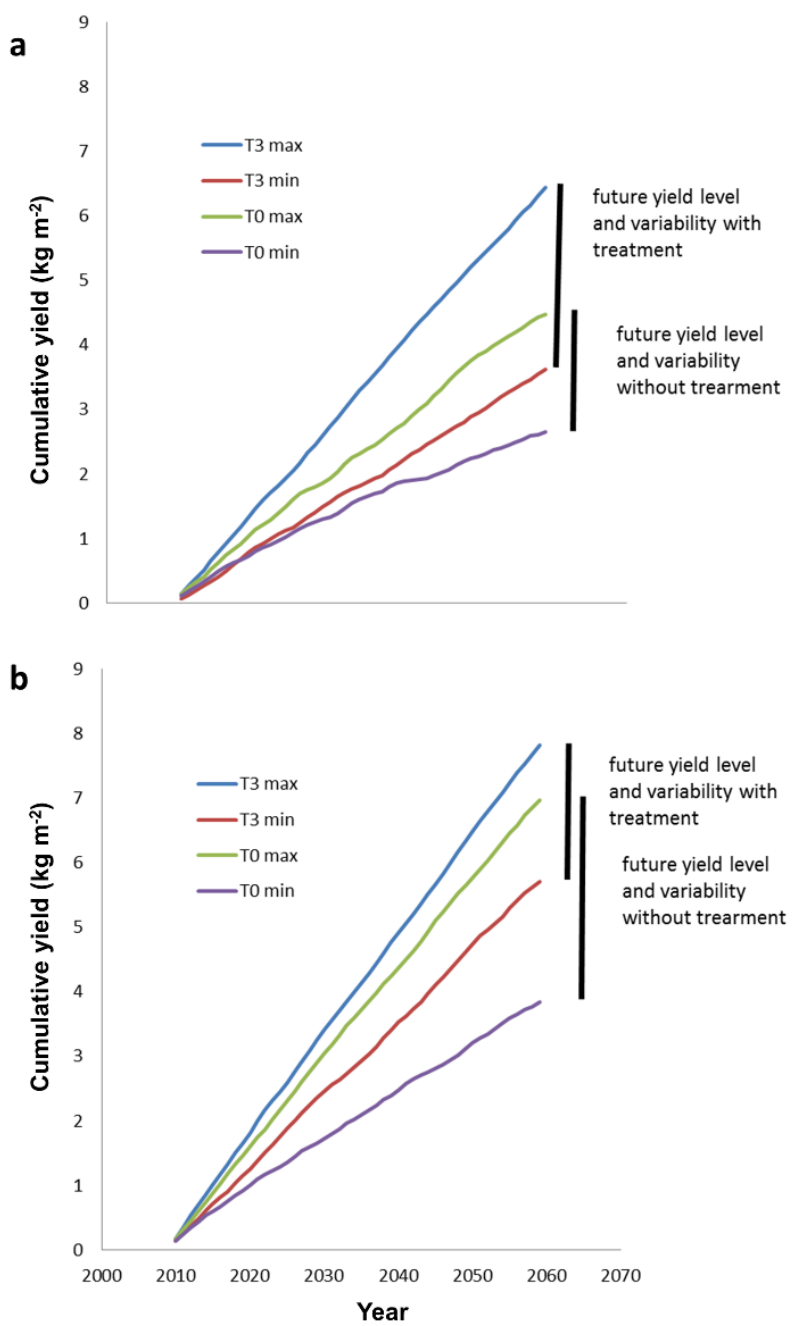

Figure 5.5 Envelopes of potential biomass production for sub-humid (a) and semi-arid (b) conditions indicating that biomass yield in the sub-humid regions tends to be secured. Rainfall data for São Jorge (annual rainfall $450 \mathrm{~mm}$ ) and Ponto Ferro (annual rainfall $300 \mathrm{~mm}$ ) respectively. 


\subsubsection{Sensitivity to climate variability with / without treatment}

Historical rainfall records, field observations and recent reports (FAO, 2015) highlight the potential rainfall variability of the climate in Cabo Verde. Thus, we consider the impact of rainfall variability on both the baseline and improved soil management conditions and the financial viability of the measures. The PESERA model has been modified to represent both the untreated plots (TO) and the treated plots (T3). The benefits of T3 are achieved through management inputs and cultivation practice.

Improvements are observed for both climate zones (sub-humid and semi-arid) when treated (T3). However, despite significant improvement in the semi-arid case, in the drier years yield does not exceed a nominal value of 0.8 -ton $\mathrm{ha}^{-1}$ as in the sub-humid case (Figure 5.4).

\subsubsection{Time series analysis of yield and probability of yield}

The time series approach allows repeated realisations of the climate to be generated from the frequency distribution of observed data, thus enabling sampling of the performance of the standard and improved practice across a much wider spectrum of climatic conditions. The envelope of potential biomass growth is derived from the modelling of repeated realisations. The maximum and minimum biomass predictions are plotted for a notional 50-year simulation for both climate zones (Figure 5.5a and 5.5b.)

Simulations of the SLM interventions indicate that biomass yield in the sub-humid regions tend to be secured (i.e. future yield level under climate variability exceeds nominal value over time). However, extreme years remain critical.

The probability of a given yield being achieved or exceeded is determined by treatment and climate variability at a given location (point). At a point, the probability distribution is derived with respect to treatment and climate (Figure 5.6). The probability for a given yield is derived from the cumulative frequency of 300 years simulated yields for treated and untreated sites in sub-humid and semi-arid climates. The generated probability is taken as the basis to distribute the probability of achieving a nominal value across the landscape based on annual rainfall totals assuming a similar distribution of observed interannual monthly variability applies across the island. 


\subsubsection{Spatial assessment at Island scale}

The probability of potential biomass growth envelopes can be considered across the island by setting a nominal limit and considering the probability of exceedence at each point based on the available climate distribution. The estimated probability for biomass growth greater than nominal values of $0.8 \mathrm{Mg} \mathrm{ha}^{-1}$ and $1.2 \mathrm{Mg} \mathrm{ha}^{-1}$ are presented in Figure 5.7. The change in the associated erosion risk is a direct result of the SLM intervention (Figure 5.8). Significant reductions of soil erosion are possible, from an average of over $15 \mathrm{Mg} \mathrm{ha}{ }^{-1}$ to below 7 ton $\mathrm{ha}^{-1}$. Average biomass production was simulated derived from the probabilities of exceedence (Figure 5.9a-b), and allowed to vary between 2 standard deviations from the the average value (Figure 5.9c-d). The effect of T3 is large relative to introduced variability in low potential arid zones, but in the most productive sub-humid part of the island, the variability effect is larger than the difference in average yields between T3 and T0, hence some negative effect (T3 - TO $<0$ ) can be observed (Figure 5.9e-f).

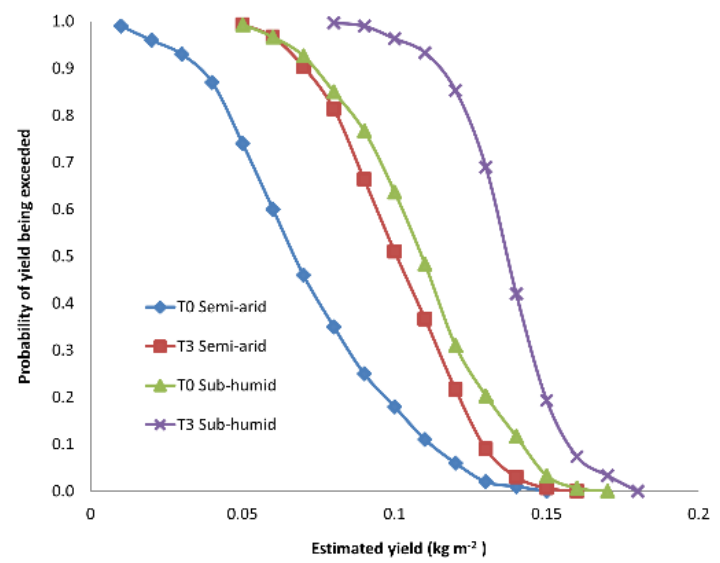

Figure 5.6 Probability of achieving yield level as a function of climatic conditions and agricultural management at two given locations.
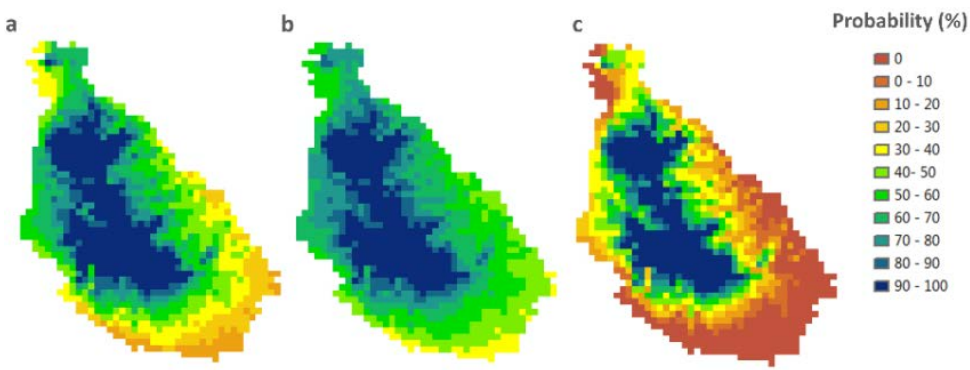

Figure 5.7 Probability of biomass production exceeding a nominal value: (a) Baseline (TO) $p>0.8 \mathrm{Mg} \mathrm{ha}^{-1}$; (b) Improved (T3) p>0.8 $\mathrm{Mg} \mathrm{ha}^{-1}$; (c) Improved (T3) p>1.2 $\mathrm{Mg} \mathrm{ha}^{-1}$. 


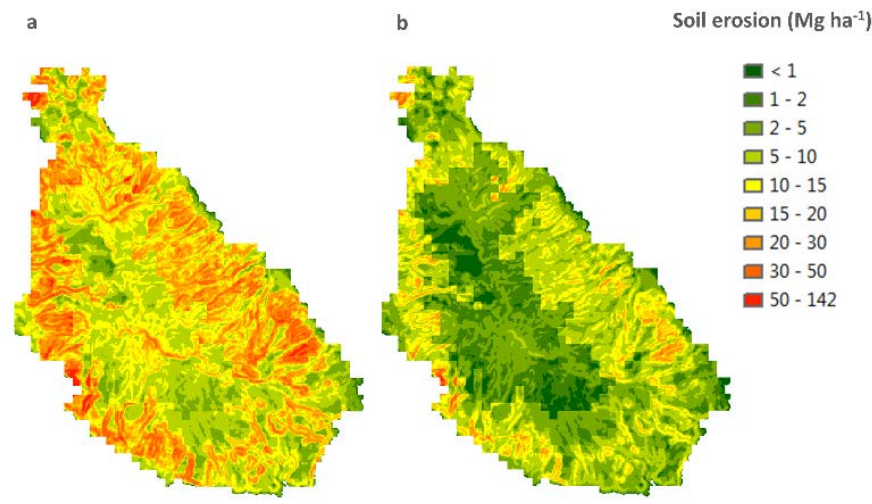

Figure 5.8 Erosion rate status for baseline TO (a) and improved T3 (b) conditions.

a

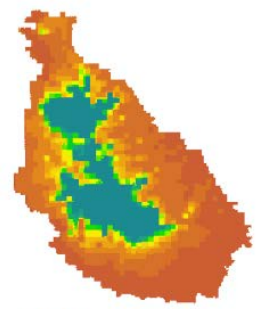

c

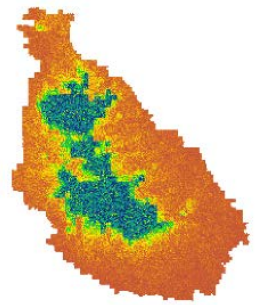

e

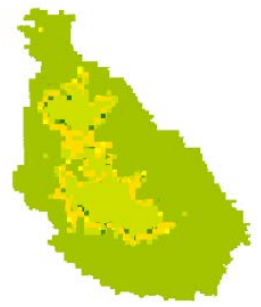

b

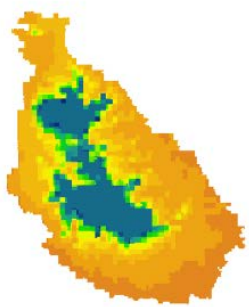

d

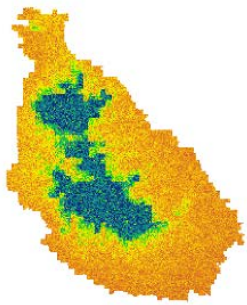

f

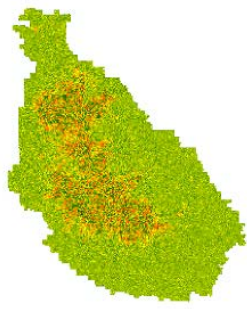

Biomass yield

$\left(\mathrm{Mg} \mathrm{ha}^{-1}\right)$

$0-0.2$

$\square 0.2-0.4$

$\square 0.4-0.6$

$\square 0.6-0.8$

$\square 0.8-1.0$

$\square \quad 1.0-1.2$

$\square \quad 1.2-1.4$

$\square 1.4-1.6$

$\square \quad 1.6-1.8$

$\square \quad 1.8-2.0$

$\square 2.0-2.2$

$\square \quad 2.2-2.4$

- $2.4-2.6$

- $2.6-2.8$

- $2.8-3.0$

- $3.0-3.5$

- $3.5-4.0$

- $4.0-4.5$

드 $4.5-5.0$

= $5.0-5.5$

( $\mathrm{Mg} \mathrm{ha}^{-1}$ )

- $<-2.5$

므 $-2.5-1.0$

口 $-1.0--0.5$

$\square-0.5-0.25$

$\square-0.25--0.1$

$\square \quad-0.1-0$

$\square$ 0 0.1

ㅁ $0.1-0.25$

$\square 0.25-0.5$

ㅁ. $0.5-0.75$

$0.75-1.0$

$=1.0-2.5$
$=2.5$

Figure 5.9 Average biomass production under TO and T3 derived from the probabilities of exceedance using generic rules (a-b), or introducing random effect of up to 2 standard deviations from the average value (cd). The difference between biomass production under average T3 (b) compared to TO (a) conditions is given in (e), and between fluctuating and average T3 conditions in (f). 

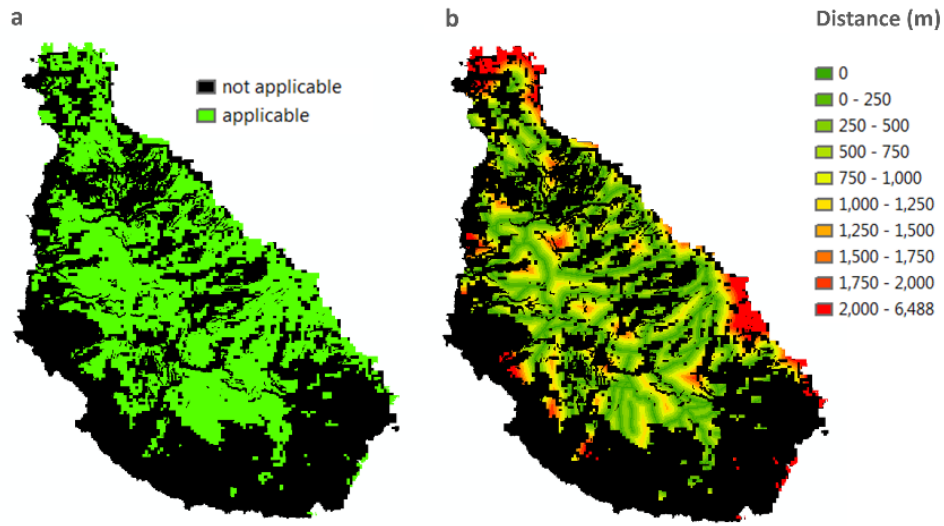

Figure 5.10 Suitability of improved technology at island scale (a) in relation to the distance to main road (b).
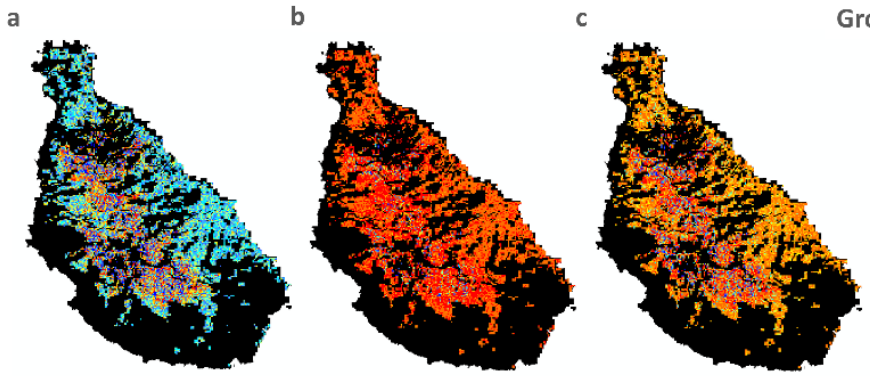

Gross margin (ECV ha-1)

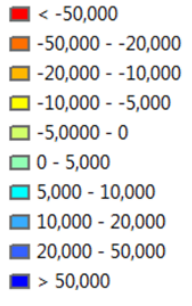

Figure 5.11 Gross margin analysis of T3 in relation to TO under three different scenarios: (a) organic inputs are locally available; (b) organic inputs are not locally available; (c) transport of manure only. All results shown in Cabo-Verdean Escudos (ECV, 100 ECV = 1 US\$).

Table 5.2 Cost-effectiveness indicators for selected ecosystem services for the T3 scenario.

\begin{tabular}{cccc}
\hline & Unit value & Total value & Cost-effectiveness \\
\hline T3 applicable area & & $41679 \mathrm{ha}$ & \\
Reduction of soil erosion & $-8.6 \mathrm{Mg} \mathrm{ha}^{-1}$ & $-358 * 10^{3} \mathrm{Mg}$ & $10060 \mathrm{ECV} \mathrm{Mg}^{-1}$ \\
Increased food production & $115 \mathrm{~kg} \mathrm{ha}^{-1}$ & $4800 \mathrm{Mg}$ & $566 \mathrm{ECV} \mathrm{kg}^{-1}$ \\
\hline I00 ECV =1 US\$ & &
\end{tabular}

Applicability limitations limit the suitability of the SLM scenario to about $42 \%$ of Santiago Island (Figure 5.10a). In addition, the distance to main roads is taken into account for 
transport costs of organic inputs to the fields for a number of situations (Figure 5.10b). This works out differently depending on the situation: if all inputs are locally available the SLM technology is an attractive investment in most parts of the island except in the high potential zones where negative results are possible because little difference in biomass production and higher costs involved in T3 compared to T0 (Figure 5.11a). However, although T3 is profitable in low potential zones it is unlikely that inputs are locally available. Therefore situations $b$ and $c$ explore the viability of the SLM technology if manure and crop residues are not locally available (Figure 5.11b) or only manure needs to be transported (Figure 5.11c). In situation b costs amount to ECV 48000 for inputs plus variable transport costs (0-14000 ECV for most remote locations), whereas in situation $b$ an allowance is made of 24000 ECV for manure only and variable transport costs. Clearly, purchasing of inputs is generally too expensive, except in few locations.

The average maximum simulated reduction of soil erosion and food production increase in the Santiago Island were $8.6 \mathrm{Mg} \mathrm{ha}^{-1}$ and $0.1 \mathrm{Mg} \mathrm{ha}^{-1}$, respectively, corresponding to a low cost-effectiveness of $10060 \mathrm{ECV}^{-1}$ ton $^{-1} 566 \mathrm{ECV}$ per kg (Table 5.2).

\subsection{Discussion}

\subsubsection{Sensitivity to climate variability}

Historical rainfall records, field observations and recent reports (FAO, 2015) highlight the potential rainfall variability of the climate in Cabo Verde. The time series simulations generate rainfall variability that allows extending the impact of rainfall and putting the observed event of the two-year field trial in context with the extended rainfall record. The observed annual rainfall range for the experimental years (2011-2012) show a return frequency range of 1 in 2 years to 1 in 5 years. Although there were marked differences in rainfall between the experimental seasons (2011 and 2012), based on the historical record both seasons fall close to the average annual rainfall. However, the intra-seasonal pattern is significantly different, with one-month dominant in 2012. High monthly rainfall in September 2012 approached a 1: 30 year return period, skewing rainfall significantly and greatly reducing the length of growing season. Thus, results do not suggest significantly unusual dry periods but do indicate a significant monthly rainfall bias, as previously reported (Smolikowski et al., 2001; Sanchez-Moreno et al., 2014; Baptista et al., 2015c).

The model can be constrained to the plot scale results with and without treatment and as such, over the 50-year simulation, the reduction in average annual runoff and erosion is of 
the same magnitude as the observed site data (Baptista et al., 2015b). This helps validate the modified PESERA model as a suitable model but requires further consideration at the field and slope scale to consider more confidently the biophysical impact of the improved SLM technique. However, as stated earlier the magnitude and direction of the observed change remains of greater value and interest when considering this spatial application.

\subsubsection{Time series analysis and probability of yield}

Improvements were observed for both climate zones (sub-humid and semi-arid) when treated with the proposed SLM (T3). However, despite significant improvement in the semi-arid case, in the drier years yield does not exceed a nominal value of $0.8-\mathrm{Mg} \mathrm{ha}{ }^{-1}$ as in the sub-humid case. Though T3 elevates biomass yield under both sub-humid and semiarid climates, risk of crop failure still exists. Results also suggest greater security or return on investment in sub-humid rather than semi-arid conditions.

The historic rainfall statistics and the multiple 50-year rainfall realisations capture a fuller range of climatic conditions, providing a unique time-series of rainfall, simulated crop yield and an envelope of the potential crop yield. Envelopes of potential biomass production help express the agricultural risk associated with climate variability and the potential of the conservation measures to absorb the risk, thus, highlighting the uncertainty of a given crop yield being achieved in any particular year. This information can directly inform or influence the adoption of conservation measures under the climatic variability of the Cabo Verde drylands.

\subsubsection{Applicability of the improved scenario}

While analysis at plot level is informative, upscaling the analysis to the island level was able to demonstrate that the viability of the improved technology is questionable from a farmer's perspective. By fluctuating the yield level to represent natural variability, it could be established that T3 could lead to yield increase in $81 \%$ of circumstances. However, given additional labour costs, if crop residues and manure are available locally, investment in the technology is attractive in $65 \%$ of cases. However, land users have to buy and transport manure to the farm, a favourable return on investment occurs in only $10 \%$ of cases, and if also crop residues have to be sourced off-farm, this drops to a mere $3 \%$. The investments involved are too high to justify investment for the benefit of reduced risk of 
poor crop yield alone. Further data are required to be able to quantify the contribution of pigeon pea to system productivity.

It seems appropriate to consider additional benefits from the improved technology, which could be applied on 41679 ha, or $42 \%$ of Santiago Island. It should be noted though that the land cover map used to inform the area of rainfed cropping (Bontemps et al., 2011) includes mosaic land cover classes, which are leading to a higher area under agriculture than observed from governmental data that shows a $50 \%$ less potential area (PEDA, 2005). Notwithstanding this discrepancy, the average reduction of soil erosion that can be achieved was simulated to be $8.6-\mathrm{Mg} \mathrm{ha}^{-1}$ (Table 5.2). Apart from the direct on-site damage, with the dominant local soil bulk density this translates in a loss of 0.6-0.7 mm of soil annually, which implies nutrient losses of i.e. $86 \mathrm{~kg} \mathrm{~N}$ and a gradual reduction of maximum available soil water. Several authors (Ali et al., 2007; Zhang et al., 2011; Xia et al., 2013; Baptista et al., 2015c) also reported similar rates of erosion-related nutrient loss. Considering the medium to long-term impact of land degradation, the cost-effectiveness of the investment for the purpose of soil conservation could, in some cases be of sufficient interest. The increased food production is, when considered in isolation, not cost-effective with a per unit cost of over three times the crop price. However, in total $4800 \mathrm{Mg}$ food could be produced extra annually, which is almost $50 \%$ more than was produced in the whole archipelago in 2014 (FAO, 2015) and could be a strategic asset from a food sovereignty perspective. There is finally a need to consider effect on the regional water balance and any improvements to off-site conditions, such as raising local water table and reducing stream erosion and sedimentation of downstream reservoirs.

While the improved technology show great biophysical potential as an adaptation strategy to climate change, there exist specific barriers to its adoption (i.e. availability of crop residue and organic amendment, which will need to be addressed to guarantee its successful application at a wider scale (Lebel et al., 2015). Moreover, for farmers to adopt technologies, these must be attractive in economic terms, i.e. have potential from a farmer's perspective, lead to cost reductions, benefit enhancements, or both (Teshome et al., 2013; Fleskens et al., 2014). Strategies to assist farmers in simultaneously conserving water and nutrients have shown promise in similar environments (Wakeyo \& Gardebroek, 2013; Zougmoré et al., 2014). In the case of Cabo Verde, improvement of animal husbandry practices seems to hold good potential as simulations highlighted insufficient financial returns for farmers with poor availability of organic amendments. The quantification of off-farm benefits to society would enable the government to decide on institutionalizing a Payment for Ecosystem Services scheme to incentivise farmers to adopt SLM technologies. 


\subsection{Conclusions}

Using the PESERA-DESMICE modelling approach, we analysed the potential benefits for upscaling an innovative land management technique - residue mulch combined with pigeon-pea hedges and an organic amendment - that emerged from field trials at Santiago Island, Cabo Verde. Biophysically, the technique offered good potential to increase yields by $20 \%$ in $42 \%$ of the Santiago Island area and reduce erosion by $8.6 \mathrm{Mg}$ ha-

${ }^{1}$, but might be prohibitively expensive in terms of cost effectiveness for farmers lacking crop residues, manure, or both. The technique elevates yield under both sub-humid and semi-arid climates with greater security for sub-humid areas even though risk of crop failure still exists due to rainfall variability. Simultaneous improvement of land management and animal husbandry would be required to fulfil the promise of the technology. In addition, a governmental payment for ecosystem services scheme could incentivise farmers to adopt the technology. Further research should also look at the downstream effects through a series of nested catchment studies to consolidate impact of the technology. Despite limited data availability and considering that the purpose of our analysis was not to extensively test, calibrate and validate the model, we conclude that PESERA-DESMICE could be calibrated to local conditions using data from two years of field experiments, complementing missing data with data from global datasets. Based on the results the PESERA-DESMICE modelling approach enables the assessment of policy options at larger scale, under variable climatic conditions, to improve soil management and, thus, resilience to future climate change. 
Appendix 1 Long-term rainfall record for S. Jorge station, Cabo Verde

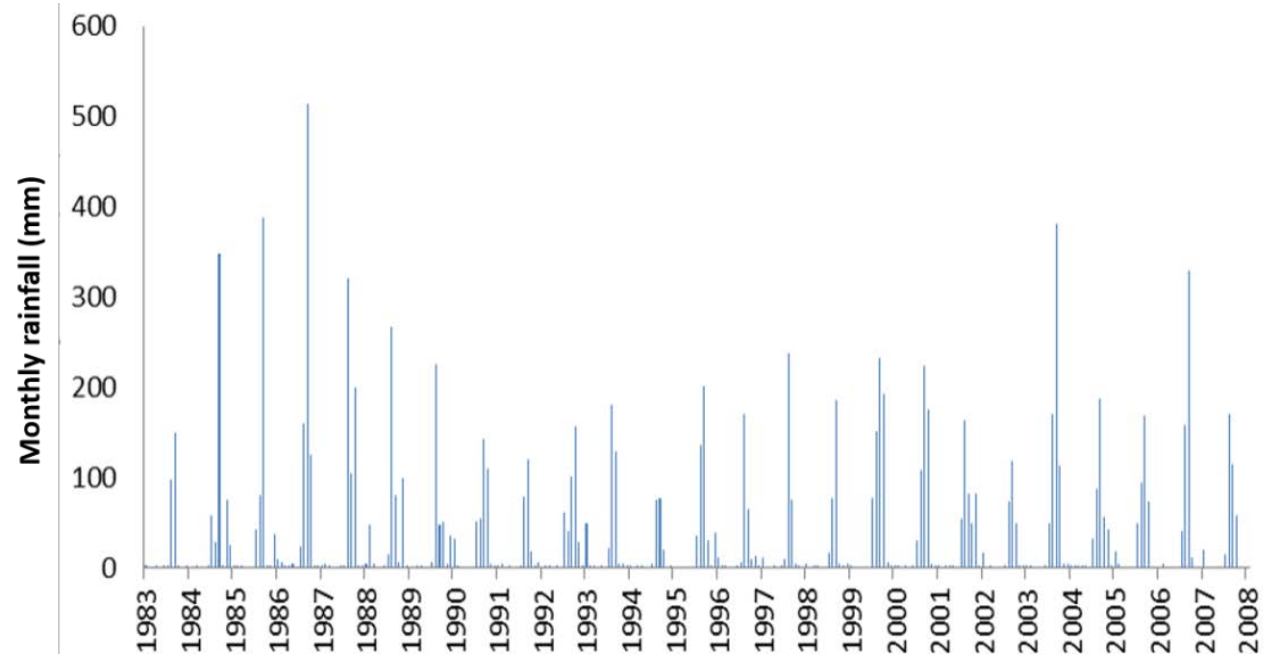


Appendix 2 Plot scale cumulative runoff and erosion rates.

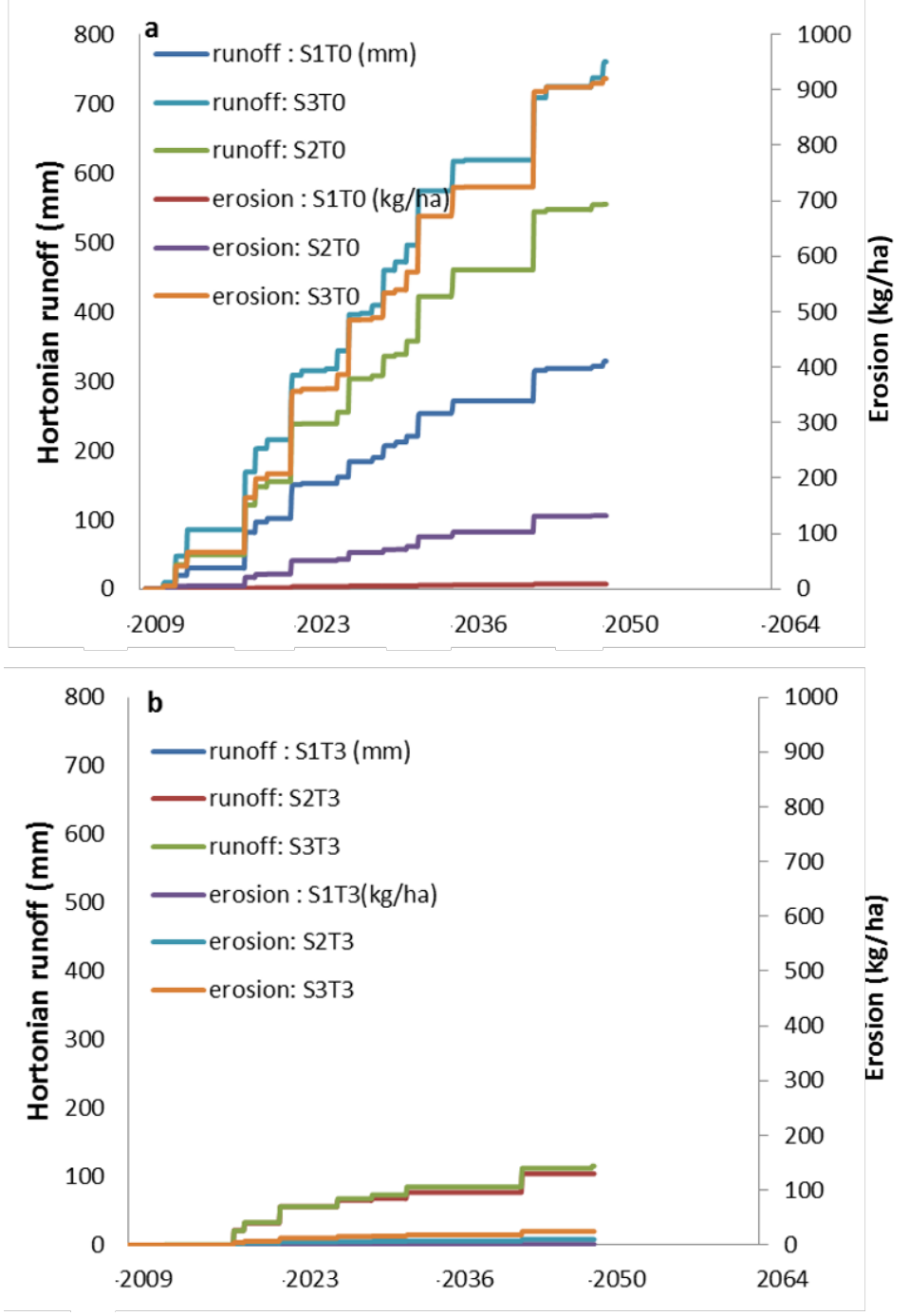




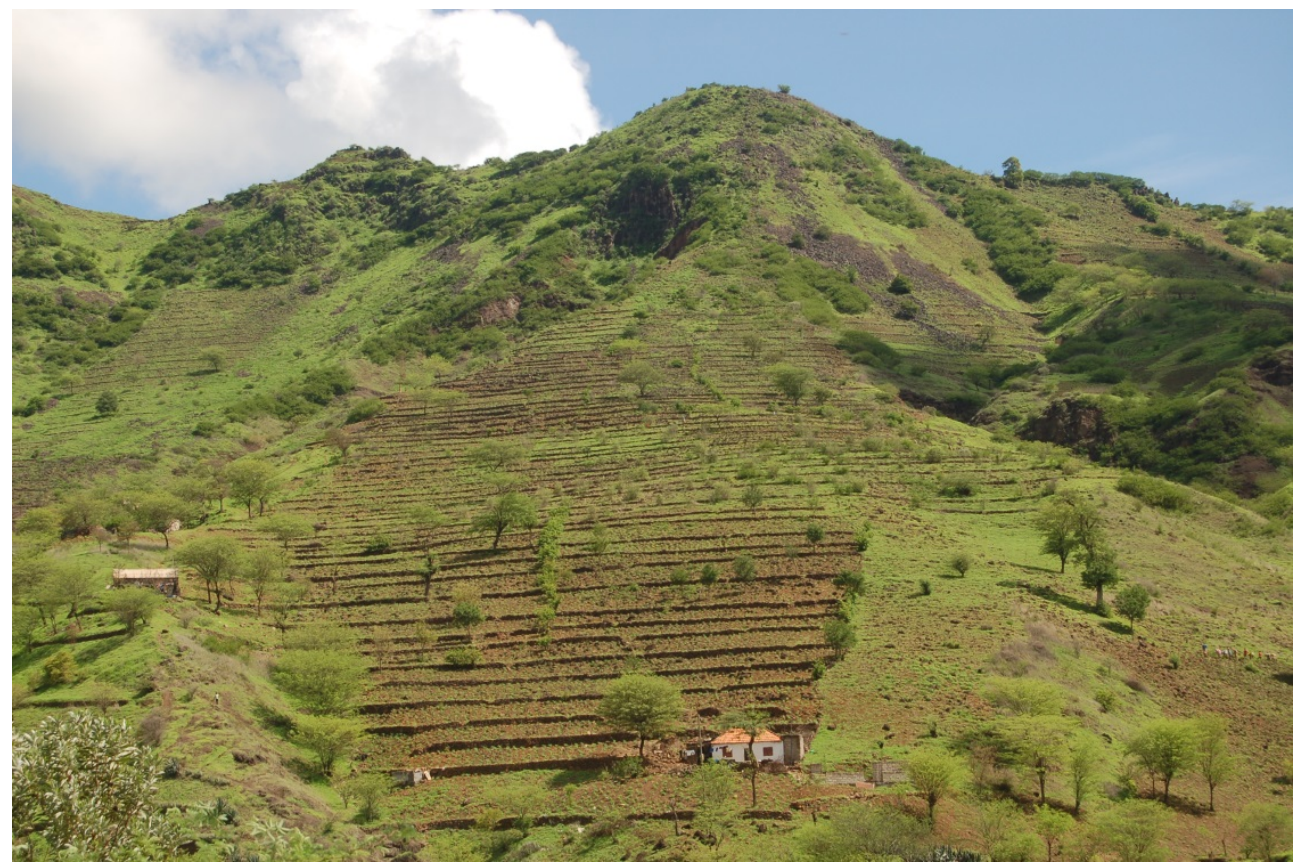




\section{Synthesis}




\subsection{Introduction: The problem to investigate}

As a Sahelian country, Cabo Verde has suffered the effects of desertification through the years, which has threatened the livelihood of the islands' population and their fragile environment (Ferreira et al., 2012; Langworthy and Finan, 1997; Liu et al., 2008). Food production in such dryland environments is challenged by steep slopes, inadequate practices, irregular intense rain, recurrent droughts, high runoff rates, severe soil erosion and declining fertility, leading to the inefficient use of rainwater. Despite enormous governmental investment in soil and water conservation techniques at watershed scale, to reverse the processes of land degradation and desertification in the country, erosion driven land degradation is still very problematic (Tavares et al., 2013), and dryland yields remain low (FAO, 2003, 2014), even in years of sufficient annual rainfall. Maize and beans occupy $>80 \%$ of the arable land in a low-input, low-yielding subsistence farming culture which still faces severe climate conditions, inadequate crop and land management practices, and increasing land degradation (Ferreira et al., 2012; Schwilch et al., 2012). For a more secure future for the people and environment of Cabo Verde, more sustainable land management practices that have been scientifically validated are needed.

Though dryland farming is a subsistence activity, it is very important for the livelihoods of smallholder farmers that rely on it for food production. However, dryland food production is becoming increasingly difficult due to lack of water for crop production resulting in low crop yields (FAO, 2003, 2009) and cannot fulfil the growing population's demand for food. As the application of conservations strategies depends on the farmers (Huenchuleo et al., 2012; Thapa and Yila, 2012), they must have a selection of integrated management options (Stroosnijder, 2003) that provide sufficient benefits against reasonable costs and simultaneously reduce dryland degradation and maintain sustainable yields.

Despite the existing knowledge that an integrated approach to water, crop and nutrient management is essential to increase crop production and optimise input, there is a lack of integrated studies on their effects (Stroosnijder, 2009). The lack of an effective involvement of farmers and rural communities has limited adoption of improved agricultural technologies by smallholder farmers, for whom it is not worth investing in dryland as long as the risk of crop failure associated with water scarcity remains a reality (Stroosnijder, 2009).

Since irregular rainfall patterns will increasingly affect agriculture, maximizing the efficiency of rainwater-use for crop production is crucial (Turner, 2004; Hassan, 2007). To contribute to the stability of food and fibber production it is therefore also crucial to explore innovative land management techniques and approaches that integrate soil 
fertility, the efficiency of rainwater-use and, at the same time, increase dryland crop productivity (Hatfield et al., 2001). Thus, more efficient use of rain in dryland agriculture deserves increased scientific attention (Stroosnijder, 2003).

The PESERA-DESMICE modelling approach is useful to facilitate the analysis of the integrated system approach at a larger scale (Esteves et al., 2013; Fleskens et al., 2014; DESIRE, 2011), while a participatory research approach is effective in enhancing the adoption of techniques and empowering of rural communities (Zougmoré et al., 2014).

Thus, this research proposed to investigate the potential of certain sustainable land management (SLM) techniques selected in collaboration with stakeholders to contribute to the optimization of soil and water management in dryland farming systems through the reduction of runoff, soil and nutrient losses and increase crop productivity.

\subsection{Answering the research questions: summary and general discussion}

To improve understanding of how to move from water erosion and water scarcity driven land degradation conditions to a more sustainable intensification of semiarid dryland areas and climate smart agriculture, this thesis addressed five questions. In this section, the previous chapters are summarised and discussed in light of these five research questions. Given that runoff and erosion related nutrient losses and crop productivity are the central theme of this research, the discussion will elaborate more on research question 4.

The summary diagram (Figure 6.1) links the topics, factors and processes involved in this thesis project. While aspects such as the reduction of runoff, erosion and soil nutrients due to application of the promising SLM techniques are dominant and contribute to improving land degradation conditions, aspects related to crop productivity (i.e. maize yield) are somewhat inconclusive due to great rainfall variability during the growing season and shading of pigeon peas on the maize plants. 


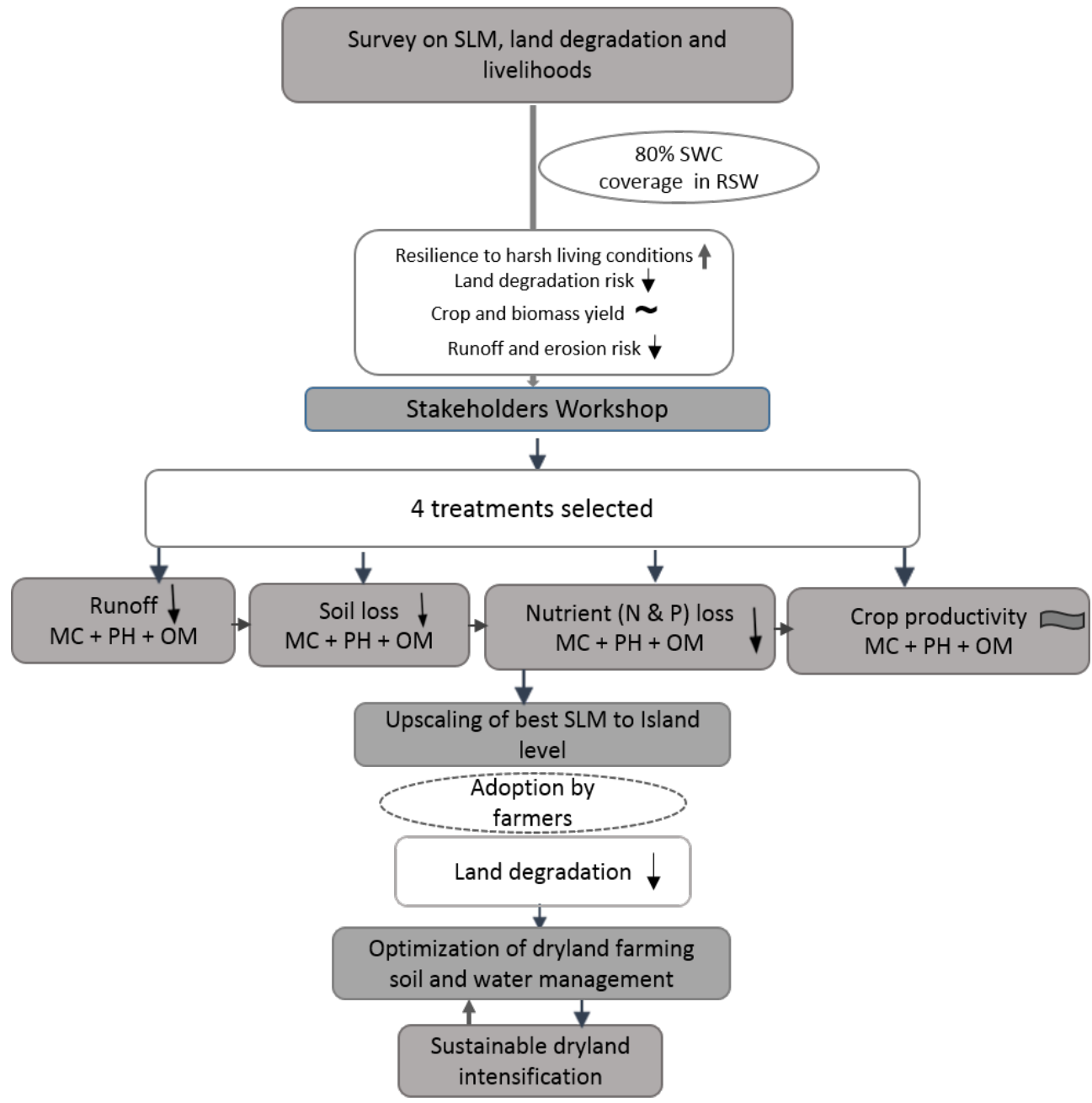

Figure 6.1 Summary diagram linking the topics, factors and processes to reduce land degradation due to water erosion and drought, towards optimization of soil and water management in dryland farming systems. Arrows pointing up and down inside the boxes indicate, respectively, the processes increasing and decreasing; while indicates fluctuation. (SLM - Sustainable Land management; SWC - soil and water conservation; RSW - Ribeira Seca Watershed; MC - mulch cover; PH - pigeon-pea hedges; OM - organic amendments) 


\section{What have the impacts of sustainable land management (SLM) strategies been on livelihoods in Cabo Verde drylands in the last decades?}

A review of the literature combined with qualitative and quantitative field surveys showed that soil and water conservation strategies implemented in Cabo Verde have positively contributed to the livelihoods of the people as well as to the mitigation of land degradation. This positive impact has been evidenced through several aspects related to SLM, namely:

- Increasing resilience to the harsh conditions by eradicating famine, mobilizing financial resources, elaborating national strategic instruments, adhering to regional and international agreements, creating an appropriate institutional set up, adopting a participatory approach, and raising stakeholders' awareness, training and capacity building. The combination of all these governance factors has contributed to the relative success of Cabo Verde in combating desertification and land degradation, and decreasing rural poverty.

- Decreasing degree, extent and trend of land degradation and desertification risk. In the Ribeira Seca Watershed $>80 \%$ of the area benefits from conservation measures which have had moderate to high effectiveness in reducing/preventing land degradation and increasing efficiency in rain-fed agriculture over time. The implementation of SLM measures modifies landscape functions at different spatial scales (Wakindiki and Ben-Hur, 2004) and in Cabo Verde they have produced dramatic changes both at plot and watershed scales, changing the lunar aspect of the landscape to a more green and pleasant one (Ferreira et al., 2013; Tavares et al., 2013). The high effectiveness of the measures, evidenced by the greener landscape, increased available water, and reduced degradation and risk of desertification, confirm that the implemented SLM measures have imparted greater resilience to the agro-ecosystems, making them able to resist droughts and land degradation.

- Crop and biomass yield increase. SLM measures have also contributed to the maintenance of the production and improvement of the environmental conditions of the treated lands in Cabo Verde by making crop production possible, and consequently improving the livelihood of the people. These positive aspects contribute to people's well-being as evidenced by farmers' testimonies showing satisfaction, for example with the pigeon-pea technology that has lead to high yield and better soil cover, with positive impacts on soil conservation, human nutrition and animal feed (Tavares et al., 2013). Evaluation of food production potential (DESIRE, 2011) showed that pigeon-pea technology can significantly increase yield both per area and per capita, decreasing production risk by $50 \%$ and increasing production area also by $50 \%$; thus, reducing poverty levels. In addition, the surface runoff water 
mobilized and stored in the dams is used for irrigation, allowing farmers to increase yield and diversify their sources of income (MDR, 2012).

- Decrease in erosion and runoff rates. At hillslope level, research has shown high effectiveness of measures such as vegetation barriers, residue mulch and organic amendments in reducing runoff and water erosion, at plot level, when compared with traditional cropping practices (maize and beans) (Querido, 1999; Smolikowski et al., 2001; DESIRE, 2011; Baptista et al., 2015a). However, these experimental results have not been applied at larger scale.

However, despite the recognised positive impact of the massive implementation of SLM measures, monitoring and assessment of biophysical and socioeconomic impacts remain insufficient and a harmonised system for scaling up the effects of SLM is still lacking. In addition, the yield of traditional crops remains low.

\section{What are the most important criteria for farmers in selection of SLM practices/techniques?}

The selection of the techniques tested in the scope of this study combined traditional and scientific knowledge in a field-based participatory approach, with the perceptions and contributions of the farmers playing a major role, as demonstrated in chapters 3 and 4 . In the first stage, from a list of potential techniques, local farmers decided which techniques to select based on their own criteria. According to the farmers that participated in the stakeholders' workshop and the perception at the end of the workshop, the most relevant factors that influenced farmers' choices were the following:

- Relevance to the specific biophysical and socioeconomic constraints of dryland production. Soil loss, low fertility and runoff from agricultural fields emerged as the three main constraints. For the three highest-priority problems, the farmers selected the use of stone walls or vegetation hedges using drought-resistant species along contour lines, and conservation farming (mulch) with partial weeding and organic fertilizers.

- Local availability of materials such as crop residues for mulch, and organic fertilizers (animal or green manure and compost). If locally available, the techniques are more likely to be selected.

- Cost effectiveness of the techniques and their local applicability. Farmers are not willing to invest in expensive techniques that do not have immediate returns or that are not applicable to certain areas. In addition, as dryland farming is not reliable due to risk of crop failure because of lack or irregularity of rain, farmers do not want to invest in rainfed drylands. 
- Land tenure/ownership. Farmers who do not own land are not willing to invest large sums of money, as they may not get the return in the time span they work the land.

- Level of farmer education and training. Farmers with higher level of education, or that have received specific training on resource management through extension or research services, are in a better position to make informed choices on land management practices.

These factors were perceived as the most important in influencing farmers' choice in the selection of techniques for this study. They also influenced the selection of the SLM techniques identified and recommended in this thesis through the participatory approach applied (Willy and Holm-Müller, 2013). Most of these factors have also been reported as determinants of adoption in several parts of the world (Chomba, 2004; Bandara and Thiruchelvam, 2008; Deressa et al., 2009; Mavunganidze et al., 2013; Willy and HolmMuller, 2013; Obayelu et al., 2014; Tesfaye et al., 2014).

\section{How do selected SLM techniques influence runoff and erosion?}

This study selected a combination of mulch, pigeon-pea hedges and an organic amendment (animal or green manure or compost) on steep slopes as a promising technique to reduce runoff and erosion from dryland agricultural fields in Cabo Verde, as indicated in chapter 3 . Mulch or a soil surfactant combined with an organic amendment also reduced runoff and erosion on gentler slopes with low erodibility. The combined technique influenced runoff and erosion either through the effect of individual components or through their synergetic effect, as explained below.

As runoff occurs when rain intensity exceeds the infiltration capacity of the soil (Lal, 1975; Schwab et al., 1993; Le Bissonnais et al., 2005) and soil erosion positively correlates with runoff (Baptista et al., 2015b), any measure that promotes infiltration will decrease both runoff and erosion. On the steep slopes, the high effectiveness of the technique in reducing runoff rates observed to negligible levels is mainly due to the protection of the soil surface by mulch and vegetation, controlling splash, runoff, rills and mass flow, as also reported by Ali et al. (2007) and Zheng et al. (2007). The residue mulch protects the soil surface from the erosive energy of rainfall. Yet, the combined technique reduces the runoff volume as well as changing the runoff-erosion relationship (Zheng et al., 2007).

The results in chapter 3 indicate that the traditional farming system lost more soil than the SLM treatments tested, but the magnitude of soil loss only exceeded the tolerable threshold value of $12 \mathrm{Mg} \mathrm{ha}^{-1}$, established for some African semiarid regions, on the steepest slope site, which lost $17 \mathrm{Mg} \mathrm{ha}^{-1}$ in a regular rainfall season. Such results and 
previous ones by Querido (1999) and Smolikowski et al. (2001) confirmed that soil erosion on Cabo Verde semiarid, steep hillsides under current traditional rain-fed farming could be excessive, leading to loss of top soil and nutrient depletion. However, the combination of mulch, pigeon-pea hedges and organic amendments (T3) was able to reduce runoff by 84 to $99 \%$ and soil erosion by 97 to $100 \%$. Even though runoff coefficients and specific erosion rates were low for the treatments ( 0 to $5.7 \%$; specific erosion rates: 0.04 to $5.22 \mathrm{~g}$ $\mathrm{m}^{-2} \mathrm{~mm}^{-1}$ rain) and control (runoff coefficient: 1.4 to $6.7 \%$; specific erosion rates: 0.04 to $2.08 \mathrm{~g} \mathrm{~m}^{-2} \mathrm{~mm}^{-1}$ rain), the application of this combination of SLM treatments will prevent long-term nutrient depletion and contribute to improve crop yield.

The mean erosion rates in this study, particularly for the flatter areas, are lower than those in other semiarid Sahelian countries (Martin, 1995; Roose, 1997; Ande et al., 2009) where $12 \mathrm{Mg} \mathrm{ha}^{-1}$ is considered a tolerable threshold value (Lal, 1998). However, given the shallow soils on steep slopes and the aggressive character of the rains in Cabo Verde (Sanchez-Moreno et al., 2013), the acceptable threshold rate should be substantially lower to ensure long-term production sustainability. Its determination should take into account soil depth, rate of soil formation, land use and landscape, while also tailoring appropriate SLM measures locally (Bui et al., 2011). The next paragraphs discuss how each individual component affects runoff and soil erosion.

Residue mulch, as a system that maintains a protective cover of vegetation on the soil surface, has been widely used to reduce runoff and erosion from agricultural fields. The beneficial effects of mulching include protection of the soil against rain impact, decrease in runoff velocity and improved infiltration capacity of the soil (Zougmoré et al., 2003). Protecting the soil surface with a dead or living cover is an effective way to reduce erosion and runoff water by dissipating raindrop energy (Lal, 1975; Mando 1997; Novara et al., 2013).

Vegetation hedges of pigeon-pea, as a perennial crop with roots deeper than those of maize and beans, can continue to produce biomass and provide soil cover after the maize and beans have been harvested. The hedges also protect the soil from raindrop impact and decrease runoff velocity.

Organic amendments (i.e. compost and animal or green manure) contribute to the integrity of soil particles, increasing aggregate stability and decreasing erodibility. Several authors (Cogle et al., 2002; Zougmoré et al., 2003; Srinivasarao et al., 2014) have also reported the positive effect of organic amendments on the reduction of runoff and soil loss in semiarid areas. However, the availability of organic matter is limited, which makes composting crucial to valorise the scarcity of organic resources. 
Soil surfactants improve infiltration, distribution and retention of water (Mobs et al., 2012), decrease runoff and increase water-use efficiency (Lentz, 2003; Cooley et al, 2009). The already high infiltration rate of the soils under natural conditions could explain the lack of response from the soil surfactant on runoff obtained in the study on the sandy- and silt-clay loam soils in steeper areas.

The positive influence of soil cover on both runoff and soil loss indicates the importance of maintaining some residue on the soil surface during erosive rainfall events, as also stated by other authors (Cerdà, 2001; Hartanto et al., 2003; Kairis et al., 2013).

\section{How do selected SLM techniques influence soil erosion related nutrient losses and crop productivity?}

One of the unique aspects of this study was evaluation of the efficacy of selected SLM techniques (residue mulching, a soil surfactant, and pigeon-pea hedges) combined with organic amendments (compost, animal and green manures) on $\mathrm{N}$ and $\mathrm{P}$ losses with eroded soil and runoff, and on crop yields in Cabo Verde drylands. It was hypothesised that the synergetic effect of the combined techniques would significantly decrease nutrient losses related to runoff and erosion, and increase crop productivity.

\section{Runoff and erosion related nutrient losses}

Soil erosion is one of the main processes causing nutrient depletion, with the amount of nutrient loss by soil erosion depending on the amount of soil loss and the nutrient content of the eroded soil, particularly the topsoil. Runoff and water erosion can transport nutrients either dissolved in solution or associated with soil particles, reducing the amount of nutrients available to support crop production (Pimentel et al., 1995; Roose, 2004). As the losses of $\mathrm{NO}_{3}-\mathrm{N}$ and $\mathrm{PO}_{4}-\mathrm{P}$ are highly correlated with the amounts of runoff and eroded soil, the techniques that reduce runoff and erosion also reduce nutrient losses.

Our results, as reported in chapter 4 , indicated that all applied treatments significantly reduced nutrient $\left(\mathrm{NO}_{3}-\mathrm{N}\right.$ and $\left.\mathrm{PO}_{4}-\mathrm{P}\right)$ losses related to runoff and eroded soil. Yet the combination of mulch with an organic amendment and pigeon-pea hedges nearly eliminated nutrient loss in the runoff and eroded soil by reducing soil loss to a minimum. The effectiveness of all applied treatments in significantly reducing nutrient losses can be attributed to the effect of individual components of the treatments (residue mulch, organic fertilizers and pigeon-pea hedges); nonetheless, the synergetic effect of the combined components seems to be more effective. 
The loss of nutrients in each treatment was mainly a function of the amount of runoff and eroded soil, and did not depend on nutrient concentrations in either runoff or sediments, corroborating other studies (Zobisch et al. 1995; Tiscareno-Lopez et al., 2004; Ali et al., 2007). This fact can also account for the considerable nutrient losses in the control plot (5 to $19 \mathrm{~kg} \mathrm{ha}^{-1}$ of $\mathrm{NO}_{3}-\mathrm{N}$ and 0.1 to $0.4 \mathrm{~kg} \mathrm{ha}^{-1}$ of $\mathrm{PO}_{4}-\mathrm{P}$, respectively), which lost the most soil, and the negligible nutrient losses in the combined treatment, which lost the least amount of soil. The mechanisms by which each component of the combined techniques influences soil erosion related nutrient losses are as follows:

Residue mulch. As the treatments containing residue mulch nearly eliminated soil loss, they nearly eliminated nutrient losses as well. Mulch protects soil against the impact of raindrops, decreases runoff velocity and improves the infiltration capacity of the soil; thus, controlling erosion and nutrient loss (Mando, 1997; Zougmoré et al., 2003; Novara et al., 2013).

Pigeon-pea hedges. The lower nutrient losses, particularly $\mathrm{PO}_{4}-\mathrm{P}$, in the eroded soil (Chapter 4) from plots with hedges indicate that the pigeon-pea hedges were effective in reducing PO4-P losses on steep slopes. Such effectiveness is due to the ability of the hedges to intercept rainfall and decrease runoff velocity, thus acting as a barrier to water erosion and decreasing nutrient losses on hilly landscapes (Gilley et al., 2012; Wolton et al., 2014).

Organic amendments. The application of organic amendments such as compost, animal or green manure to the soil can improve aggregate stability and thus reduce $\mathrm{NO}_{3}-\mathrm{N}$ and $\mathrm{PO}_{4}-$ $P$ losses as previously reported (Zougmoré et al., 2009). The higher nutrient inputs in the applied treatments than nutrient loss, and the greater losses in the traditional system (control) that received no inputs, indicate that nutrients were lost from the original soil, a premise also supported by Ali et al., 2007. In addition, the negative nutrient balance in the traditional system could lead to medium/long-term nutrient depletion in the soil, crop nutrient deficiency, and lower yields.

\section{Crop development and productivity}

As reported in chapter 4, the effects of the applied treatments on dryland maize development and yield were inconsistent across the different sites, mainly due to the irregularity of the rainfall that affected the crops at crucial stages of development during the experimental season. The short and irregularly distributed rainfall also led to overall low crop yield. Nonetheless, the way each of the different treatment components might influence crop yield is discussed below. 
Residue mulch. The expected positive effect of mulch on crop productivity is associated with its ability to promote infiltration, conserve moisture and, thus, make more water available for the crop. In addition, decomposed residue mulch adds organic matter and nutrients to soil (Bhardwaj, 2013; Tanveer et al., 2014). In this study, despite higher maize yield for the treatment containing mulch in some study sites, results about the effect of the mulch on maize yield was not conclusive. Smolikowski et al. (2001) also questioned the ability of mulch combined with L. leucocephala hedges to improve the use of water resources by grain crops in semiarid regions.

Pigeon-pea hedges. The anticipated benefits of vegetation hedges come from their ability to reduce runoff and erosion, promoting infiltration of water into the soil, thus increasing water availability for the associated maize crop. Pigeon-pea, as a leguminous crop, may also provide nitrogen to the soil, further benefiting the maize crop. However, in this study, maize yield and development were hindered and treatment effect on yield was masked due to shading by the fully developed pigeon-pea hedges. This constraint suggests that the hedges were spaced too closely and/or that the pigeon-pea plants needed to be managed to eliminate shading of the maize crop, as also reported by Zougmoré et al. (2003) in studies with hedges of $L$. leucocephala.

Organic amendments as fertilizers. Compost, animal and green manures supply nutrients to crops and improve soil structure, contributing to increased infiltration and above ground biomass (Diacono and Montemurro, 2010; Bouajila and Sanaa, 2011). In this study (Chapter 4), when these organic amendments were combined with the soil surfactant, they resulted in a significant increase in maize yield, even though the plant nutrient content did not reach the sufficiency level. This finding corroborates other studies (Baptista, 2000; 2003) that reported maize yield increase with the application of animal manure and Leucaena pruning as $\mathrm{N}$ source for dryland maize. Other studies that have reported positive effects of Leucaena leaf biomass on the $\mathrm{N}$ economy and productivity of maize include Mittal et al., (1992) and Sharma and Behera, (2010).

Regarding the fact that the organic fertilizers increased $\mathrm{N}$ content of maize plant tissue, but did not reach the recommended sufficiency level of $25-35 \mathrm{~g} \mathrm{~kg}^{-1} \mathrm{~N}$ (Modesto et al., 2014), there may be several reasons. Among them are: i) the low $\mathrm{N}$ content of the compost, animal and green manures applied $\left(23,24\right.$ and $38 \mathrm{~g} \mathrm{~kg}^{-1}$, respectively), in which case higher rates would be required to supply adequate nutrients to the maize plants; and ii) the slow rate of $\mathrm{N}$ mineralisation, particularly in the manure, which would reduce the amount of $\mathrm{N}$ available to the crops during the cropping season (Baptista, 1996). Given that $\mathrm{N}$ is a limiting nutrient for dryland maize in Cabo Verde (INIDA, 1997) and maize is a nutrient-demanding staple crop, symptoms of deficiency appear and grain yield and 
quality decline when $\mathrm{N}$ levels drop below the sufficiency range (Modesto et al. 2014). Since the availability of organic fertilizers is limited, increasing their amount would not feasible, but compost enriched with chemical fertilizers could be a solution to promote among farmers

\section{What is the potential of the promising SLM technique to upscale the biophysical impact and financial viability at Santiago Island under variable climate scenarios?}

This study considered the PESERA-DESMICE modelling approach to extend biophysical and economic benefits of the promising land management technique (residue mulch combined with pigeon-pea hedges and an organic amendment - T3), selected in chapters 3 and 4, across typical field conditions on Santiago Island, under variable climatic conditions. Chapter 5 reported the results of our evaluation of the biophysical impact and financial viability of the improved conservation technique (T3) compared to a traditional practice (T0). The historic rainfall statistics and 50 -year rainfall realizations provide a unique timeseries of rainfall and an envelope of the potential crop yield. Envelopes of potential biomass production help express the agricultural risk associated with climate variability and the potential of the conservation measures to absorb the risk, highlighting the probability of a given crop yield being achieved in any particular year.

The fact that the SLM technique offered good potential to elevate yield by $20 \%$ in $42 \%$ of the Santiago Island area, and reduce erosion by $8.6-\mathrm{Mg}^{-1}$ hander both sub-humid and semi-arid climate regions, highlights its positive biophysical impact. The combination of an erosive climate (i.e. high intensity rainfall) and slope gradients is responsible for high rates of erosion, i.e. 10 to $20 \mathrm{Mg} \mathrm{ha}^{-1} \mathrm{yr}^{-1}$ on hilly drylands under conventional management, supporting findings in response to research question 3.

The high implementation cost, however, indicates that the technique might not be economically feasible for farmers lacking inputs. Still, the findings can directly inform policy options and/or influence adoption of conservation measures under the climatic variability of the Cabo Verde drylands, thus supporting greater resilience to future climate change. 


\subsection{General conclusions}

This thesis investigated alternative SLM techniques to contribute to the sustainable intensification of agriculture in the Cabo Verde drylands though the reduction of runoff, soil erosion and nutrient losses, combining traditional and scientific knowledge in a fieldbased participatory process with local stakeholders. The following main conclusions can be highlighted:

- The orientation of rural development policies towards combating desertification and reducing poverty in Cabo Verde, based on massive implementation of SLM measures, has built resilience to extreme drought periods and land degradation. Although the positive impact of the implemented SLM measures on the environment, economy, food production, livelihood and combating land degradation in the country is generally acclaimed, monitoring and assessment of biophysical and socioeconomic impacts of SLM remain incipient, poorly quantified and documented, and are restricted to a few isolated studies with limited scope. This study contributes to a better integration of biophysical and socioeconomic aspects of SLM through a robust scientific framework and a harmonised system for scaling up proven sustainable land management practices.

- The erosive character of rainfall in Cabo Verde associated with the traditional practice of rain-fed farming can cause considerable losses of soil and water from agricultural fields, leading to soil degradation. The soils of the experimental sites had relatively high capacities for water retention and low runoff rates, but their continuous cultivation without protection will eventually accelerate the degradation of the land. A combination of mulch, pigeon-pea hedges and an organic amendment on steep slopes can significantly reduce runoff and erosion from dryland agricultural fields in Cabo Verde, thus contributing to a more efficient use of rainwater at the field level. Mulch or a soil surfactant combined with an organic amendment can also improve the use of rainwater on gentle slopes with low erodibility. The high effectiveness of the combined technique in reducing runoff and erosion is mostly due to mulch' direct soil coverage, protecting the soil from rainfall impact.

- All applied treatments significantly contributed to reduce nutrient $\left(\mathrm{NO}_{3}-\mathrm{N}\right.$ and $\mathrm{PO}_{4}-\mathrm{P}$ ) losses from the plots at all sites. The combination of mulch with an organic amendment and pigeon-pea hedges nearly eliminated nutrient loss in the runoff and eroded soil, reducing soil loss to a minimum. The effects of the treatments on dryland maize yield were inconsistent, due to the irregularity of the rainfall that affected the crops at crucial stages of development during the experimental season. Combining the use of crop-residue mulches with organic nutrient sources 
and vegetation runoff barriers could reduce nutrient losses in the runoff and sediments, thereby maintaining or improving soil productivity. However, to guarantee higher maize yields, the pigeon-pea must be sufficiently managed to avoid shading of the maize plants. The integrated SLM technique (T3) is important for prevention of nutrient depletion and at least maintenance of crop yield.

- The selected (combined) conservation technique has good potential to increase yields ( $20 \%$ in $42 \%$ of the area) and reduce erosion by $8.6 \mathrm{Mg} \mathrm{ha}^{-1}$ across Santiago Island, but might not be cost-effective for the smallholder farmers lacking inputs. The climate envelopes help express the agricultural risk associated with climate variability and the potential of the conservation measures to absorb the risks, thus, highlighting the uncertainty of a given crop yield being achieved in any particular year. The findings can directly inform policy options and/or influence adoption of conservation measures under the climatic variability of the Cabo Verde drylands and support increased resilience to future climate change. The PESERA-DESMICE model proved to be a useful and effective modelling tool for estimation of the financial viability and biophysical impact of the improved techniques.

\subsection{Implications of mitigating erosion-induced land degradation: Preventing erosion, runoff and nutrient losses}

The findings of this study make a significant contribution to the scientific community, the society and the international policy context for sustainable dryland intensification, as synthesized in the following subsections.

\subsubsection{Scientific contribution}

The scientific value of this research lays in its multidisciplinary nature, combining biophysical, environmental and agro economical aspects at local community, watershed, island and national levels.

The results derived from this research contribute to the current scientific debates on Climate-Smart Agriculture (CSA) technologies promoted by the United Nations (FAO, 2010), and also highlighted by Zougmoré et al. (2014) for sub-Saharan Africa. Indeed, the technology combining mulch with pigeon-pea hedges and an organic source of nutrients 
can be a promising CSA practice that could be widely used by smallholder farmers in semiarid regions to maintain food production and secure farmers' livelihoods, while contributing to ecosystem services by storing water in the soil. In addition, our results regarding this type of SLM measure contribute to the scientific debate around sustainable intensification (SI) of drylands provided that solutions to reach cost-effectiveness are implemented, prioritizing sub humid and semiarid areas. The CSA and the SI approaches seem highly complementary, as $\mathrm{SI}$ is an essential means of adapting to climate change while CSA provides the foundations for enabling sustainable intensification (Campbell et al., 2014).

The participatory approach, which consisted of a combination of stakeholder workshops with on-farm participatory trials and farmer-hosted visits to experimental plots, was the basis for stakeholders' cooperation, future assessments of strategies and adoption of the best technology options, contributing to farmers' empowerment. This approach, which was a modification of the DESIRE approach (Schwilch, 2012), could be used as a conceptual framework to up-scale SLM techniques across the country and to other regions with similar agro-climatic characteristics.

At the decision making level, the validated PESERA-DESMICE modelling approach serves as a decision support tool for decision makers to predict erosion, nutrient losses, food security and cost-effectiveness under current and alternative land management and climate scenarios at national, regional and international level (Fleskens et al., 2014; Stringer et al., 2014).

\subsubsection{Societal and economic contribution}

The social-economic contribution of this research is multi-faceted. Firstly, it is linked to the significant need that exists in Cabo Verde for conservation measures to ensure food and income for the local people. Indeed, the selected SLM techniques will contribute to preventing and/or controlling further land degradation in the fragile Cabo Verdean environment. This will support government policy that aims to increase agricultural production and at the same time protect the environment. Secondly, the tested land management techniques were selected in close collaboration with the local stakeholders and, thirdly, selection and implementation of field trials were based on local knowledge and stakeholder input. The integrated participatory planning methods used throughout the research project are expected to increase the likelihood of farmers to apply the techniques because they have been part of the process and have seen the efficiency of the techniques. 
Even though the country already benefits from significant coverage of SLM techniques, the SLM techniques and approaches covered in this research differ from those in the sense that the participatory approach contributes to empower farmers, and the selected techniques take into account the integration of runoff and erosion control, nutrient management and crop yield, positively contributing to people's livelihoods. It is essential to stress that most soil and water conservation measures previously implemented in the country have been focused more on combating desertification even though they may contribute to improve crop yield, and less on other prevalent degradation issues and what can directly benefit the people. As such, this research contributes an approach that has the potential to broaden protection and productivity of the land through engagement of the local people in a way that combines local knowledge, scientific process and economic analysis in order to maximize participation.

Results of this research can be disseminated to other watersheds in the country and, thus, up-scaled at island or country level. Further dissemination could be done through the WOCAT network (www.wocat.net) by including the results in the WOCAT database for further use and implementation by others in similar environmental conditions around the world.

\subsubsection{International policy context contribution}

At international policy level, the results of this research directly contribute to policy context on issues such as the Sustainable Development Goals (SDGs) of the United Nations Convention, the Climate Smart Agriculture and the Sustainable Intensification approaches. Of the SDGs, the land degradation neutrality (LDN) is of particular importance (UNCSD, 2012) as the concept aims at securing the current amount of the global productive land, (UNCCD, 2013). Achieving LDN through SLM practices such as the combined technique of residue mulch with vegetation hedges and an organic nutrient source, as selected in this research, will ensure the productivity of lands by maintaining healthy soils.

Thus, implementing the selected technique at larger scale will lead to sustainable and more resilient soils, which underpin land productivity. Since land degradation can be both a cause and a consequence of climate change (UNCSD, 2012) techniques that combat land degradation will also offer opportunities to mitigate the impacts of climate change. 


\subsection{Research challenges and further research direction}

While hoping that this research will contribute to optimize soil and water management in dryland farming systems, a number of challenges remain to be addressed to fully understand, tackle and reverse water erosion and drought-induced land degradation, and make the selected SLM techniques more appealing to farmers. These challenges suggest that further research is needed on the following issues:

- One of the main limitations of this study was the short period of time during which the field research was conducted. Coupled with the variability in rainfall distribution and pigeon-pea shading of the maize crop, this did not allow consistent and realistic evaluation of crop productivity. Thus, further research should focus on long-term field trials to include a wider range of rainfall conditions aiming to consolidate yield data and establish trends for the semiarid steep hillsides. To optimize yield and adapt to availability of organic amendments, composting with available animal and green manure enriched with mineral fertilizers could be an alternative option.

- Evaluation of pigeon-pea yield as an additional incentive for farmers to adopt the selected SLM technique since neither field evaluation nor the PESERA-DESMICE model accounted for the pigeon-pea yield.

- Better integration of biophysical and socioeconomic aspects of SLM through a robust scientific framework and a harmonised system for scaling up sustainable land management, to allow extrapolation of results to climatic zones with similar physiographic and socio-economic characteristics, if adoption is feasible. The approach taken throughout this thesis, depicted in figure 6.1, contributes to the integration of the biophysical and socioeconomic aspects of SLM, but would need adaptation according to the site-specific conditions.

- The 50-year simulation of runoff and erosion with the PESERA-DESMICE model was of similar magnitude as observed field data, thus, helping to validate the modified PESERA model as suitable. Nevertheless, it requires further consideration at field and slope scale for more confidence in the biophysical impact of SLM techniques.

- Evaluation of downstream effects through a series of nested catchment studies to consolidate the impacts of the technology.

\subsection{Policy and extension recommendations}

Cabo Verde's authorities should reinforce their policy towards SLM practices to optimize soil and water management. SLM benefits reach far beyond the potential to reduce land degradation and desertification. SLM also addresses global concerns such as water 
scarcity, resource-use efficiency, food security, poverty relief, climate change, and biodiversity conservation (FAO, 2011). These multiple benefits justify investments in SLM as it is vital to move beyond purely monetary valuation of ecosystem services, and to learn from the mistakes of similar measures introduced elsewhere as also recommended by Reed et al. (2015). Since in Cabo Verde most efforts in SLM measures aim to improve land management as a whole, there is also a need to address the soil as a limited and threatened resource to restore its productive potential, enabling food security.

In this regard, policies should consider legislation on the following:

- Establishment of soil, topographic and conservation conditions regarding where to practice dryland farming in order to avoid cultivation of excessively sloped land, which is especially susceptible to water erosion, without conservation measures.

- Incentives for farmers to adopt sustainable land management techniques that increase the use of rainwater, prevent further degradation of soil fertility, and potentially increase sustainable dryland yields, particularly on the semiarid hillsides.

- Standardization of tolerable threshold erosion rates for hilly areas that have shallow soils and are highly susceptible to soil erosion as a contribution to attaining the Land Degradation Neutrality goal. Unless authorities take serious priority actions to reverse the soil degradation process, soil degradation neutrality may be an unrealistic goal to attain in Cabo Verde and sub-Saharan Africa, in the near future.

- Support of sustainable dryland intensification for resilient livelihoods and food security through sustainable livelihood diversification; sustainable agriculture; community-based natural resource management; integrated watershed management; and education and training programmes on the sustainable use of natural resources.

- A concerted approach between stakeholders and the scientific community, similarly to the DESIRE approach, which could be up-scaled to the national level and integrated into long-term programs. Such an approach should also include the PESERA-DESMICE modelling to evaluate biophysical impact and financial viability of SLM measures.

Likewise, extension services are recommended to:

- Promote compost production to valorise the scarcity of organic resources in the country and region. Developing local capacities and empowering rural communities to produce good quality compost and to use basic agricultural equipment could contribute to reducing the labour demand while enabling the widespread implementation of SLM techniques.

- Increase effective farmer involvement through demonstration plots, farmer interactions and education about the need to protect the soil. This will be crucial for the successful implementation and assumption of SLM techniques. 


\section{Literature cited}

Abdi, O. A., Glover, E.K., Luukkanen, O. 2013. Causes and Impacts of Land Degradation and Desertification: Case Study of the Sudan. International Journal of Agriculture and Forestry 3(2): 40-51.

Adimassu Z., Mekonnen, K. Yirga, C., Kessler, A. 2014. Effect of soil bunds on runoff, soil and nutrient losses, and crop yield in the central highlands of Ethiopia. Land Degradation \& Development 25 (6): 554-564.

Adu-Gyamfi, J.J., Myaka, F.A., Sakala, W.D., Odgaard, R., Vesterager, J.M., Høgh-Jensen, H. 2007. Biological nitrogen fixation and nitrogen and phosphorus budgets in farmermanaged intercrops of maize-pigeonpea in semi-arid southern and eastern Africa. Plant \& Soil 295: 127-136.

Aerial Photography and Imagery, Ortho-corrected-2010 Digital Orthophotos. 2010. Lafayette County, Florida, US.

Ali, I., Khan, F., Bhatti, A.U. 2007. Soil and nutrient losses by water erosion under monocropping and legume intercropping on slopping land. Pakistan Journal of Agriculture Research 20: 3-4.

Amaral, I. 2007. Santiago de Cabo Verde: A terra e os Homens, Memórias da Junta de Investigação do Ultramar, segunda série, $n^{\circ} 48$, Universidade do Algarve, Portugal, p. 444.

Ande, O.T., Alaga, Y., Oluwatosin, G.A. 2009. Soil erosion prediction using MMF model on highly dissected hilly terrain of Ekti environs in southwestern Nigeria. International journal of Physical Science 4 (2): 53-57.

Araya, A., Stroosnijder, L. 2010. Effects of tied ridges and mulch on barley (Hordeum vulgare) rainwater use efficiency and production in Northern Ethiopia. Agricultural water management 97: 841-847.

Araya, A., Stroosnijder, L., Girmay, G., Keesstra, S.D. 2011. Crop coefficient, yield response to water stress and water productivity of teff (Eragrostis tef (Zucc.) Agricultural Water Management 98 (5): 775-783.

Araya, T., Cornelis, W., Nyssen, J., Govaerts, B., Bauer, H., Gebreegziabher, T., et al. 2011. Effects of conservation agriculture on runoff, soil loss and on crop yield under rainfed conditions in Tigray, Northern Ethiopia. Soil Use and Management 27: 404414.

Araya, T., Negatu, W., Brouwer, R., van der Zaag, P. 2014. Understanding soil conservation decision of farmers in the Gedeb watershed, Ethiopia. Land Degradation \& Development 25: 71-79.

Bandara, D.G.V.L., Thiruchelvam, S. 2008. Factors affecting the choice of soil conservation practices adopted by potato farmers in Nuwara Eliya District, Sri Lanka. Tropical 
Agricultural Research and Extension 11: 49-54.

Baptista, I. 1996. Use of animal manure to supply $\mathrm{N}$ to crops in Cape Verde. Master thesis. University of Georgia, Athens, USA. p 222.

Baptista, I. 2000. Effects of organic and inorganic fertilizers on the nutrient status and yield of dryland crops in Cape Verde. In Proceedings of the workshop of the InterCRSP project: Improving and sustaining food and row material Production in West Africa. Bamako. Mali

Baptista, I. 2003. Use of Leucaena leucocephla pruning as nitrogen source for Dryland crops in Cape Verde. In Technology adaptation under the interCRSP. A New model for international Collaborative Research and Technology Transfer: The NMR InterCRSP Project in West Africa. Bertelsen M. and Brewster C. Editors. Virginia Tech.

Baptista, I., Fleskens, L., Ritsema, C.J., Querido, A., Ferreira, A.D., Tavares, J., et al. 2015a. Soil and water conservation strategies in Cabo Verde and their impacts on livelihoods: an overview from the Ribeira Seca Watershed. Land 4: 22-44.

Baptista, I., Ritsema, C., Geissen, V. 2015c. Effect of integrated water-nutrient management strategies on soil erosion mediated nutrient loss and crop productivity in Cabo Verde drylands. PLOS ONE 10 (7): e0134244.

Baptista, I., Irvine, B., Fleskens, L., Geissen, V., Ritsema, C. 2015d. Assessing the biophysical impact and financial viability of soil management technologies under variable climate in Cabo Verde drylands: the PESERA-DESMICE approach. Land Degradation \& Development. Accepted.

Baptista, I., Ritsema, C.J., Querido, A, Ferreira, A.D.F, Geissen, V. 2015b. Improving rainwater-use in Cabo Verde drylands by reducing runoff and erosion. Geoderma 237-238: 283-297.

Baptista, I., Tavares, J. 2011. Highlights of work carried out in the DESIRE project. Based on research at INIDA, Cape Verde. DESIRE Project; 10. Available: www.desire-his.eu

Barrow, C.J. 1991. Land Degradation: Development and Breakdown of Terrestrial Environments. Cambridge: Cambridge University Press.

Barry, O., Smolikowski, B., Roose, E. 1995. Bilan de la lutte anti-érosive dans les zones d'agriculture pluviale au Cap-Vert, un projet innovant, le PRODAP. Agric. Dév. CIRAD-CA 5: 57-68.

Bationo, A., Kihara, J., Vanlouwe, B., Waswa, B., Kimetu, J, 2007. Soil organic carbon dynamics, functions and management in West African agro-ecosystems. Agriculture systems 94 (1): 13-25.

Bationo, A., Lompo, F., Koala, S. 1998. Research on nutrient flows and balances in West Africa: state of the art. Agriculture, ecosystems \& environment 71: 19-35.

Bhardwaj, R.L. 2013. Effect of mulching on crop production under rainfed condition - a review. Agricultural Reviews 34 (3): 188-197.

Blaikie, P., Brookfield H. 1987. Land Degradation and Society. London: Methuen.

Blake, G.R., Hartge, K. 1986. "Bulk density," in Methods of Soil Analysis, Part 1, A. Klute, Ed., vol. 9 of Agronomy Monograph, pp. 363-375. America Society of Agronomy, Madison, Wis, USA, 2nd edition. 
Bontemps, S., Defourny, P., Van Bogaert, E., Arino, O., Kalogirou, V., Ramos, P.J. 2011. GLOBCOVER 2009 Products Description and Validation Report. European Space Agency and Université Catolique de Louvain. 53 pp. Available: http://due.esrin.esa.int/globcover/LandCover2009/GLOBCOVER2009_Validation_ Report_2.2.pdf.

Bossio, D., Geheb, K. Critchley, W. 2010. Managing water by managing land: Addressing land degradation to improve water productivity and rural livelihoods. Agricultural Water Management 97: 536-542.

Botha, J.J., van Rensburg, L.D. Anderson, J.J., Henseley, M., Machelli, M.S., van Saden, P.P., et al. 2003. Water conservation techniques on small plots in semi-arid areas to enhance rainfall use efficiency, food security and sustainable crop production. Report No 1176/1/03. Water research commission. Pretoria, South Africa: WRC.

Bouajila, K., Sanaa, M. 2011. Effects of organic amendments on soil physico-chemical and biological properties. Journal of materials and Environmental science 2: 485-490

Bu, L-d., Liu, J-I., Zhu, L., Luo, S-S., Chen, X-p., Shi-qing Li, S-q. 2013. The effects of mulching on maize growth, yield and water use in a semi-arid region. Agricultural Water Management 123: 71-78.

Buerkt, A., Piepho, H.P., Bationo, A. 2002. Multi-site time-trend analysis of soil fertility management on crop production in sub-Saharan West Africa. Experimental agriculture 38: 163-183.

Bui, E.N., Hancock, G.J., Wilkinson, S.N. 2011. Tolerable' hillslope soil erosion rates in Australia: Linking science and policy. Agriculture, Ecosystems and Environment 144: 136-149.

Campbell, B.M, Thornton, P., Zougmore, R., van Asten P., Lipper, L. 2014. Sustainable intensification: What is its role in climate smart agriculture? Current Opinion in Environmental Sustainability 8: 39-43.

CDP2012/PLEN. 2011. Committee for development policy, expert group meeting for review of the list of the least developed countries. In Proceedings of the Monitoring the Progress of Graduated Countries-Cape Verde, New York, NY, USA, 16-17 January.

Center for International Earth Science Information Network (CIESIN), Columbia University, and Information Technology Outreach Services (ITOS), University of Georgia. 2013. Global Roads Open Access Data Set, Version 1 (gROADSv1). Palisades, NY: NASA Socioeconomic Data and Applications Center (SEDAC). http://dx.doi.org/10.7927/H4VD6WCT.

Cerdà, A. 1996. Seasonal variability of infiltration rates under contrasting slope conditions in Southeast Spain. Geoderma, 69 217-232.

Cerdà, A. 2001. Effects of rock fragment on soil infiltration, inter-rill runoff and erosion. European Journal of Soil Science 52 (1): 59-68.

Chambers, J.C., Brown, R.W. 1983. Methods for vegetation sampling and analysis on revegetated mined lands. Gen. Tech. Rep. INT-151. Ogden, UT: USDA Forest Service, Inter-mountain Forest and range experiment station.

Chomba, G.N. 2004. Factors affecting smallholder farmers' adoption of soil and water 
conservation practices in Zambia. Master's thesis. Michigan State University.

Cogle, A.L., Rao, K.P.C., Yule, D.F., Smith, G.D., George, P.J., Srinivasan, et al. 2002. Soil management for Alfisols in the semi-arid tropics: erosion, enrichment and runoff. Soil use and management 18: 10-17.

Cooley, E.T., Lowery, B., Kelling, K.A., Speth, P.E., Madison, F.W., Bland, et al. 2009. Surfactant use to improve soil water distribution and reduce nitrate leaching in potatoes. Soil Science 174: 321-329.

Cooper, P.J.M., Dimes, J., Rao, K.P.C., Shapiro, B., Shiferow, B., Twomlow, S. 2012. Copping better with current climatic variability in the rain-fed farming systems of the subSaharan Africa: An essential first step in adapting to future climate change. Agriculture Ecosystem and Environment 126: 24-35.

Cowie, A.L., Penman, T.D., Gorissen, L., Winslow, M.D., Lehmann, J., Tyrrell, T.D., et al. 2011. Towards sustainable land management in the drylands: Scientific connections in monitoring and assessing dryland degradation, climate change and biodiversity. Land Degradation \&. Development 22: 248-260.

Dass, A., Sudhishri, S., Lenka, N., Patnaik, U. 2011. Runoff capture trough vegetative barriers and planting methodologies to reduce erosion, and improve soil moisture, fertility and crop productivity in Southern Orissa, India. Nutrient cycling in Agroecosystem 89 (1): 45-47.

Defersha, M.B, Quraishi, S. Melesse, A. 2011. The effect of slope steepness and antecedent moisture content on interril erosion, runoff and sediment size distribution in the highlands of Ethiopia. Hydrology of Earth System Science 15: 2367-2375.

Department for International Development (DFID). 1999. Sustainable Livelihood Guidance Sheets. Available online: http://www.livelihoods.org (accessed in June 2014).

Deressa, T., Hassan R. M., Ringler C., Alemu T. and Yesuf M. 2009. Determinants of farmers' choice of adaptation methods to climate change in the Nile Basin of Ethiopia. Global Environmental Change 19 (2): 248-255.

DESIRE (Desertification Mitigation and Remediation of Land). 2011. Pesera Model Simulation for Ribeira Seca Watershed. DESIRE Scientific Report Series (WP 5.3), University of Leeds: Leeds, UK. Available at http://www.desire-his.eu. (Accessed in June 2014).

DGA (Direç̧ão Geral do Ambiente). 2004. PANAll-Segundo Plano de Acção Nacional para o Ambiente (2004-2014). Ministério do Ambiente, Agricultura e Pescas: Praia, Cabo Verde.

DGASP (Direcção Geral de Agricultura, Silvicultura e Pecuária). 2013. Inventario Florestal Nacional, Praia, Cabo Verde.

Diacono, M., Montemurro, F. 2010. Long-term effects of organic amendments on soil fertility. A review. Agronomy for Sustainable Development 30 (2): 401-422

Diniz, A.C., Matos, G.S. 1986. Carta de Zonagem Agro-ecológica e de Vegetação de Cabo Verde: I-Ilha de Santiago. In Garcia da Orta; Serie de botanica 8 (1-2): 39-82. 
Drechsel, P., Giordano, M., Gyiele, L. 2004. Valuing Nutrients in Soil and Water: Concepts and Techniques with examples from IWMI studies in the Developing World. IWMI Research report 82. International Water Management Institute. Colombo.

Ehlers, K., Lobos Alva, I., Montanarella, L., Müller, A., Weigelt, J. 2013. Soils and land in the SDGs and the post-2015 development agenda. A proposal for a goal to achieve a Land Degradation Neutral World in the context of sustainable development. Berlin, Germany. Available at: www.globalsoilweek.org

Erenstein, O. 2003. Smallholder conservation farming in the tropics and sub-tropics: a guide to the development and dissemination of mulching with crop residues and cover crop. Agriculture, Ecosystems and Environment 100: 17-37.

Esteves, T.C.J., Kirkby, M.J., Shakesby, R.A., Ferreira, A.J.D., Soares, J.A.A., Irvine, B. et al. 2012. Mitigating land degradation caused by wildfire: Application of the PESERA model to fire-affected sites in central Portugal. Geoderma 191: 40-50

FANRPAN (Policies for a Food secure Africa). 2012. Climate Smart Agriculture: more than technologies are needed to move smallholder farmers toward resilient and sustainable livelihoods. Policy Brief 2, Volume XIII.

FAO. 1993. Agro-ecological land resources assessment for agricultural development planning. A case study of Kenya resources database and land productivity. World soils resources report 71. ISSN 0532-04.

FAO. 2003. Agriculture and Food in Cape Verde. Available at: http://earthtrends.wri.org/

FAO. 2007. The State of Food and Agriculture: Paying Farmers for Environmental Services. FAO: Rome, Italy.

FAO. 2011. The State of the World's Land and Water Resources for Food and Agriculture: Managing Systems at Risk. FAO: Rome, Italy, Earthscan: London, UK.

FAO. 2013. FAOSTAT Country profile - Cabo Verde. Available: http://www.fao.org/index/en/?iso=CPV (Accessed May 2015).

FAO. 2014. Evolution of crop production. FAOSTAT, Country profile CVP. Available at: http://faostat.fao.org/site/567/default. (Assessed in 2014)

FAO. 2015. GIEWS Country Briefs - Cabo Verde. Available: http://www.fao.org/giews /countrybrief/country.jsp?code=CPV

Ferreira, A.D.F., Tavares, J., Baptista, I., Coelho, C.O.A., Reis, A., Varela, L., et al. 2013.

Efficiency of overland and erosion mitigation techniques at Ribeira Seca, Santiago

Island, Cabo Verde. In Overland Flow and Surface Runoff, Hydrological Science and Engineering Book Series, Wong, T.S.W., Ed., Nova Science Publishers, Inc.:

Singapore, p. 113-135.

Fleskens, L., Irvine, B., Kirkby, M.K., Nainggolan, D., Reed, M.S., Termansen, M. 2009. A model that integrates the main biophysical and socio-economic processes interacting within an agro-ecosystem (WP 5.1 Coarse scale model development). In DESIRE report series number 63. Series: Scientific reports. University of Leeds (Leeds), United Kingdom. Available at http://www.desire-his.eu. (Accessed in June 2014).

Fleskens, L., Nainggolan, D., Stringer, L.C. 2014. An Exploration of Scenarios to Support Sustainable Land Management Using Integrated Environmental Socio-economic 
Models. Environmental Management 54 (5): 1005-1021

Franzluebbers, A.J. 2002. Water infiltration and soil structure related to organic matter and its stratification with depth. Soil \& Tillage Research 66: 197-205

Gao, X. Wu, P. Zhao, X. Wang J., Shi, Y. 2014. Effects of land use on soil moisture variation in a semi-arid catchment: implications for land and agricultural water management. Land Degradation \& Development 25: 163-172.

Geissen, V., Kampichler, C., López-de Llergo-Juárez, J.J., Galindo-Acántara, A. 2007. Superficial and subterranean soil erosion in Tabasco, tropical Mexico: Development of a decision tree modelling approach. Geoderma 139 (3-4): 277-287

Gilley, R.S., Durso, L.M., Eigenberg, R.A., Marx, D.B., Woodbury, B.I. 2012. Narrow grass hedge control of nutrient loads following variable manure application. American Society of Agricultural and Biological Engineers 54 (3): 847-855.

Gruver, J.B. 2013. Prediction, prevention and remediation of soil degradation by water erosion. Nature Education Knowledge 4 (12): 2.

Haagsma, B., Reij, C. 1993. Frentes de trabalho: Potentials and limitations of large scale labour employment for soil and water conservation in Cabo Verde. Land Degradation \& Development 4: 73-85.

Hallsworth, E. G. 1987. Anatomy, physiology and psychology of erosion. ISBN 0-47191212- The International Federation of Institutes of Advanced Study. John Wiley \& Sons Ltd., Chichester.

Han, J.G., Li. Z.B., Li, P., Tian, J.L. 2010. Nitrogen and phosphorus concentrations in runoff from a purple soil in an agricultural watershed. Agricultural Water Management 97 (5): 757-762.

Hartanto, H., Prabhu, R., Widayat, A. Asdack, C. 2003. Factors affecting runoff and soil erosion: plot-level soil loss monitoring for assessing sustainability of forest management. Forest Ecology and Management 180: 361-374.

Hassan, M.H.A. 2007. Building Capacity in the Life Sciences in the Developing World. Cell131 (3): 433-436. doi:10.1016/j.cell.2007.10.020

Hatfield, J.L., Sauer, T.J. Prueger, J.H. 2001. Managing soils to achieve greater water use efficiency. Agronomy Journal 93: 271-280.

Hensley, M., Bennie, A.T.P., van Rensburg, L.D., Botha, J.J. 2000. Review of 'plant available water' aspects of water use efficiency under irrigated and dryland conditions. Water SA 37, No. 5.

Hessel, R., Reed, M.S,. Geeson, N., Ritsema, C., van Lynden, G., Karavitis, C.A., et al. 2014. From framework to action: the DESIRE approach to combat desertification. Environmental Management 54(5): 935-50.

Hessel, R., Van den Berg, J., Kaboréc, O., Van Kekema, A., Verzandvoort, S., Dipama J-M,. Diallo, B. 2009. Linking participatory and GIS-based land use planning methods: A case study from Burkina Faso. Land Use Policy 26: 1162-1172

Huang, M., Liang, T., Wang, L., Zhou, C. 2015. Effects of no-tillage systems on soil physical properties and carbon sequestration under long-term wheat-maize double cropping system. Catena 128:195-202 
Huenchuleo, C., Barkmann, J., and Villalobos, P. 2012. Social psychology predictors for the adoption of soil conservation measures in Central Chile. Land Degradation \& Development 23: 483- 495. DOI: 10.1002/Idr.1093

INGRH. 2010. Instituto Nacional de Gestão e Desenvolvimento dos Recursos Hídricos. Plano de Acção Nacional para Gestão Integrada dos Recursos Hídricos-PAGIRE. INGRH Serie No 45, 2, República de Cabo Verde: Praia, Cabo Verde.

INIDA (Instituto Nacional de Investigação e Desenvolvimento Agrário). 1997. Manual de fertilidade do solo e fertilização das culturas. São Jorge dos Órgãos - República de Cabo Verde.

INIDA (Instituto Nacional de Investigação e Desenvolvimento Agrário). 2006. Avaliação da produtividade das culturas de sequeiro. Relatório do estudo realizado pelo INIDA para o Agriculture Cooperative Development International ACDI/VOCA, São Jorge, Cabo Verde.

INIDA (Instituto Nacional de Investigação e Desenvolvimento Agrário). 2013. Avaliação económica de 4 explorações agrícolas em Santiago. Relatório de actividades, São Jorge dos Órgãos, Cabo Verde.

INIDA/DESIRE. 2008. Characterization of the Ribeira Seca - Santiago Island - Cape Verde Hotspot. Field Guide to the DESIRE 2nd plenary meeting.

INIDA-DESIRE (Instituto nacional de Investigação e Desenvolvimento Agrário Desertification Mitigation and Remediation of Land). 2008. Characterization of the Ribeira Seca Watershed-Santiago Island-Cabo Verde Hotspot. Field Guide for the DESIRE 2nd Plenary Meeting, Praia, Cabo Verde.

INMG (Instituto Nacional de Meteorologia e Geofísica). 2010. Dados anuais de pluviometria referentes as estações de São Jorge, Vale de mesa e Ribeirinha. Sal. Cabo Verde

IPCC (Intergovernmental Panel on Climatic Change). 2001. "Impacts, Adaptation and vulnerability". A report of working group II of the Intergovernmental Panel for Climate Change. Summary for policy makers.

IPCC. 2007. Intergovernmental Panel on Climatic Change. Summary for Policymakers: An Assessment of the Intergovernmental Panel for Climate Change, Valencia Spain, pp. 1-18. Parry, M.L., Canziani, O.F., Palutikof, J.P., van der Linden, P.J., and Hanson, C.E. (eds). Cambridge University Press, Cambridge, United Kingdom and New York, NY, USA.

Irvine, B., Kosmas, C. 2003. PESERA User's Manual. Pesera technical report deliverable 15, European Commission funded fifth framework project - contract QLK5-CT 199901323, 34p.

Jackson, M.L. 1982. Soil Chemical analysis. Prentice-Hall Inc. England, New Jersey. USA.

Jarvis, A.; Lau, C.; Cook, S.; Wollenberg, E.; Hansen, J.; Bonilla, O.; Challinor, A. 2011. An integrated adaptation and mitigation framework for developing agricultural research: synergies and trade-offs. Experimental Agriculture 47: 185-203.

Johnson, D.L., Lewis, L.A. 1995. Land Degradation: Creation and Destruction. Oxford: Blackwell.

Kairis, O., Karavatis, C., Kounalaki, A., Salvati, L., Kosmas, C. 2013. The effect of land 
management practices on soil erosion and land degradation in an olive grove. Soil Use and Management 29: 597-606.

Khan, F., Khan, S., Fahad, S., Faisal, S., Hussain, S., Ali, S., Ali, A. 2014. Effect of different levels of Nitrogen and Phosphorus of the phenology and yield of maize varieties. American Journal of Plant Science 5: 2582-2590.

Kirkby, M.J., Irvine, B.J., Jones, R.J.A., Govers, G., \& the PESERA team. 2008. The PESERA coarse scale erosion model for Europe. I. - Model Rationale and implementation. European journal of Soil Science 59: 1293-1306.

Kogbe, J.O.S., Adediran, J.A. 2003. Influence of nitrogen, phosphorus and potassium application on the yield of maize in the savana zone of Nigeria. African Journal of Biotechnology 2 (10): 345- 349.

Lal, R. 1975. Role of mulching techniques in tropical soil and water management. Technical Bulletin IITA, Ibadan, Nigeria.

Lal, R. 1995. Erosion-Crop Productivity Relationships for Soils of Africa. Soil Science Society of America Journal 59: 661-667.

Lal, R. 1998. Mulching effects on runoff, soil erosion and crop response on Alfisols in Western Nigeria. Journal of Sustainable Agriculture 11: 2-3.

Lal, R. 2009. Laws of sustainable soil management. Agronomy for Sustainable Development 29: 7-9

Langworthy, M., Finan, T. 1997. Waiting for Rain: Agriculture and Ecological Imbalance in Cape Verde. Technology and Engineer Book; Lynne Rienner Publishers: Boulder, CO, USA, 1997; p. 212.

Le Bissonais, Y,. Daroussin, J., Jamagne, M., Lambert, J.J., le Bas, C., King, D., et al. 2005. Pan-European soil crusting and erodibility assessment from the European Soil Geographical data base using pedotransfer rules. Advances in environmental monitoring and modelling 2: 1-15.

Lebel, S., Lorenz, S., Jackson, L. Forster, P., Fleskens, L. 2015. Evaluation of In Situ Rainwater Harvesting as an Adaptation Strategy to Climate Change for Maize Production in Rainfed Africa. Water resources management. DOI: 10.1007/s11269015-1091-y

Lentz, R.D. 2003. Inhibiting water infiltration with polyacrylamide and surfactants: application for irrigated agriculture. Journal of soil and water conservation 58(5): 290-300.

Lesourd, M. 1995. État et société aux îles du Cap-Vert. Collection «Hommes et Sociétés». Éditions Karthala: Paris, France, p. 524.

Liniger, H.P., Mekdaschi Studer, R., Hauert, C., Gurtner, M. 2011. Sustainable Land Management in Practice-Guidelines and Best Practices for Sub-Saharan Africa. TerrAfrica: World Overview of Conservation Approaches and Technologies (WOCAT): Berne, Switzerland, Food and Agriculture Organization of the United Nations (FAO): Rome, Italy.

Liu, J., Fritz, S., van Wesenbeeck, C.F.A., Fuchs, M., You, L., Obersteiner, M., Yang, H. 2008. A spatially explicit assessment of current and future hotspots of hunger in SubSaharan Africa in the context of global change. Global and Planetary Change 64 (3- 
4): 222-235.

Lobell, D.B.; Schlenker, W.S.; Costa-Roberts, J. 2011. Climate trends and global crop production since 1980. Science 333: 616-620.

Lopes, V., Mayer, J. 1993. Watershed management program on Santiago Island, Cabo Verde. Environmental Management 17: 51-57.

Mando, A. 1997. The effect of mulch on the water balance of Sahelian-crusted soil. Soil Technology 11: 121-138.

Mannaerts, C.M. 1986. Contribution à l'évaluation de l'érosion des sols au Cap Vert. Rapport Inédit, GCP/CVI/002/BEL.FAO, Food and Agriculture Organization (FAO): Rome, Italy, p. 43.

Mannaerts, C.M. 1993. Assessment of the Transferability of Laboratory Rainfall-Runoff and Rainfall-Soil Loss Relationship to Field and Catchment Scales: A Study in the Cape Verde Islands. Ph.D. Thesis, University of Twente, Enschede, the Netherlands.

Mannaerts, C.M., Gabriels, D., 2000. Rainfall erosivity in Cape Verde. Soil Tillage Research. $55: 207-212$.

Martin, P. 1995. Ader Doutchi Macgia (Niger). Notes sur l'historique des stratégies de Lutte antiérosif. Bull. Réseau Erosion 15, 266-282.

Mavunganidze, Z., Madakadze I.C., Mutenje, M.J., Nyamangara, J. 2013. Factors affecting the choice of conservation agriculture practices adopted by smallholder cotton farmers in Zimbabwe. African Journal of Agricultural Research 8 (17): 1641-1649.

McSweeney, C., New, M., Lizcano, G. 2010. UNDP Climate Change Country Profiles: Cabo Verde. Available: http://country-profiles.geog.ox.ac.uk/ (Accessed May 2015).

MDR. 2012. Ministério de Desenvolvimento Rural. Diagnóstico da implementação dos instrumentos: Plano Estratégico de Desenvolvimento Agrícola - Plano Nacional de Investimento Agrícola (PEDA-PNIA). Praia, Cabo Verde.

Middleton, N., Stringer, L.C., Goudie, A., Thomas, D.S.G. 2011. The Forgotten Billion: MDG Achievement in the Drylands. UNCCD-UNDP, New York and Nairobi.

Millennium Ecosystem Assessment (MA). 2005. Ecosystems and Human Well-being. World Health Organization, Geneva, Switzerland.

Mingguo, Z., Qiangguo, C., Hao, C. 2007. Effect of vegetation on runoff-sediment yield relationship at spatial scales in hilly areas of the Loess Plateau, North China. Acta Ecologica Sinica 27 (9): 3572-3581.

Ministério de Desenvolvimento Rural (MDR). 2012. Diagnóstico da implementação dos instrumentos: Plano Estratégico de Desenvolvimento Agrícola - Plano Nacional de Investimento Agrícola (PEDA-PNIA). Praia, Cabo Verde.

Mittal, S.P., Grewal, S.S., Agnihotri, Y., Sud, A.D. 1992. Substitution of nitrogen requirement of maize through leaf biomass of Leucaena leucocephala: agronomic and economic considerations. Agroforestry systems 19: 207-216.

Mobs, T.L., Peters, R.T., Davenport, J.R., Evans, M.A., Wu, J.Q. 2012. Journal of Soil and Water Conservation 67 (4): 275-285.

Mobs, T.L., Peters, R.T., Davenport, J.R., Evans, M.A., Wu, J.Q. 2012. Journal of Soil and Water Conservation 67 (4): 275-285. 
Modesto, V.C., Parent, S-E., Natale, W., Parent, L.E. 2014. Foliar nutrient balance standards for Maize (Zea mays L.) at high yield level. American Journal of Plant Science 5: 497-507.

Montenegro, A.A.A., Abrantes, J.R.C.B., Lima, J.L.M.P., Singh, V.P, Santos, T.E.M. 2013. Impact of mulching in soil and water dynamics under intermittent simulated rainfall. Catena 109: 139-149.

Moreno, A., Pereira, L.S. 2005. As obras de engenharia rural e os seus impactos nos recursos hídricos em Cabo Verde. 7ạ Silusba da APRH: Évora, Portugal.

Morgan, R.P.C. 1985. Establishment of plant cover parameters for modelling splash and detachment. In: Soil Erosion and Conservation. Eds. S.A. Swaify, W.C. Moldenhauer e A. Lo. p. 377-383.

Musinguzi, P., Ebanyat, P., Tenywa, J.S., Basamba, T.A., Tenywa, M.M., Mubiru, D. 2015. Precision of farmer-based fertility ratings and soil organic carbon for crop production on a Ferralsol. Solid Earth 6 (3), pp. 1063-1073.

Mutekanga, F.P., Kessler, A., Leber, K., Visser, S. 2013. The use of stakeholders' analysis in Integrated Watershed Management. Mountain Research Development 33, 122-131

NAPA. 2007. National Adaptation Programme of Action on Climate Change (NAPA 20082012). Global Environmental Fund/United Nations Development Programme (GEF/UNDP): Praia, Cabo Verde.

Nelson, D.W., Sommers, L. E. 1982. Total carbon, organic carbon and organic matter. In: page, A.L. Miller, R.H., Kenney, D.R. (eds.). Methods of soil analysis. Part 2. American Society of Agronomy, Madison, Wisconsin, USA. p 539-577.

Neufeldt, H.; Jahn, M.; Campbell, B.M.; Beddington, J.R.; DeClerck, F.; De Pinto, A.; et al. 2013. Beyond climate-smart agriculture: toward safe operating spaces for global food systems. Agriculture \& Food Security 3:16.

Novara, A., Gristina, L., Guaitoli, F., Santoro, A., Cerdà A. 2013. Managing soil nitrate with cover crops and buffer strips in Sicilian vineyards. Solid Earth 4: 255-262.

O'Geen, A.T., Elkins, R., Lewis, D. 2006. Erodibility of Agricultural Soils, with Examples in Lake and Mendocino Counties. University of California. Division of Agriculture and Natural Resources. ANR Publication 8194. http://anrcatalog.ucdavis.edu (consulted May 2015).

Obayelu, O. A., Adepoju, A.O., Idowu, T. 2014. Factors influencing farmers' choices of adaptation to climate change in Ekiti State, Nigeria. Journal of Agriculture and Environment for International Development (JAEID) 108 (1): 3-16.

Oldeman, L.R. 1997. Global extent of Soil degradation. In D.J. Greenland and I. Szaboles (ed): Soil Resilience and Sustainable Land Use. CAB International. Wallinford. P. 99118.

Olsen, S.R., Sommers, L. E. 1982. Phosphorus. In: page, A.L. Miller, R.H., Kenney, D.R. (eds.). Methods of soil analysis. Part 2. American Society of Agronomy. Madison, Wisconsin, USA. p 403-430.

PEDA. 2005. Agriculture et peche : strategie de developpement a l'horizon 2015 \& plan d'action 2005-2008. Ministério do Ambiente, Agricultura e Pesca (MAAP). Praia, Cabo Verde. 
Pimentel, D, Kounang, N. 1998. Ecology of Soil Erosion in Ecosystems. Ecosystems 1: $416-$ 426.

Pimentel, D. 2006. Soil Erosion: A Food and Environmental Threat. Environment, Development and Sustainability 8 (1): 119-137.

Pimentel, D., Harvey, C., Resosudarmo, P., Sinklair, K., Kurz, D., McNair, et al. 1995. Environmental and economic costs of soil erosion and conservation benefits. Science 267: 1117-1122.

Poesen, J., Nachtergaele, J., Verstraeten, G., Valentin, C. 2003. Gully erosion and environmental change: importance and research needs. CATENA 50 (2-4): 91-133.

Pretty, J. 1995. Participatory learning for sustainable agriculture. World Development 23: 1247-1263.

Querido, A.L. 1999. Watershed System Analysis for Evaluating the Efficiency of Soil and Water Conservation Works: A Case Study in Ribeira Seca, Santiago Island, Cabo Verde. Faculty of Geo-Information Science and Earth Observation of the University of Twente (ITC): Enschede, the Netherlands.

Ramakrishna, A., Tam, H.M., Wani, S.P., Long, T.D. 2006. Effect of mulch on soil temperature, moisture, weed infestation and yield of groundnut in northern Vietnam. Field Crops Research 95: 115-125.

Reed, M.S. 2008. Stakeholder participation for environmental management: A literature review. Biological Conservation 141: 2417-2431.

Reed, M.S., Buenemann, M., Atlhopheng, J., Akhtar-Schuster, M., Bachmann, F., Bastin, G., et al. 2011. Cross-scale monitoring and assessment of land degradation and sustainable land management: A methodological framework for knowledge management. Land Degradation \& Development 22: 261-271.

Reed, M.S., Fraser, E.D.G., Morse, S., Dougill, A.J. 2005. Integrating methods for developing sustainability indicators that can facilitate learning and action. Ecology and Society 10, r3.

Reed, M.S., Stringer, L.C., Dougill, A.J., Perkins, J.S. Atlhopheng, J.R., Mulale K., Favretto, N. 2015. Reorienting land degradation towards sustainable land management: Linking sustainable livelihoods with ecosystem services in rangeland systems. Journal of Environmental Management 151: 472-485

RGA. 2004. Recenseamento Geral da Agricultura. Ministério do ambiente, Agricultura e Pescas. Praia. Cabo Verde.

Robinson, L.W., Polly, J., Ericksen, C.S., Worden, J.S. 2014. Sustainable intensification in drylands: What resilience and vulnerability can tell us? Agricultural Systems 135: 133-140

Rockström, J, Barron J., Fox P. 2002. Rainwater management for increased productivity among small-holder farmers in drought prone environments. Physical Chemistry of the Earth 27: 949-959.

Rockström, J. 2003. Resilience building and water demand management for drought mitigation. Physical Chemistry of Earth 28: 869-877. 
Rockström, J., Karlberg, L., Wani, S.P., Barron j., Hatibud, N., Oweise, et al. 2010. Managing water in rainfed agriculture - the need for a paradigm shift. Agricultural Water Management 97:543-550.

Rockstrom, J., Kaumbutho, J. Mwalley, A.W., Nzabi, M., Temesgen, L., Mawenya, J., et al. 2010. Conservation farming strategies in East and Southern Africa: Yields and rainwater productivity from on-farm action research. Soil \& Tillage research 103: 23-32.

Roose, E. 2004. Eroded carbon and selectivity of sheet erosion at plot scale in tropical and Mediterranean areas and enrichment ratios: Influence of green cover, soils and erosion processes on slopes of tropical countries. Bulletin erosion 22: 74-94.

Roy, S., Arunachalam K, Dutta BK, Arunachalam A. 2010. Effect of organic amendments of soil on growth and productivity of three common crops viz. Zea mays, Phaseolus vulgaris and Abelmoschus esculentus. Applied soil ecology 45 (2): 78-84.

Ryan, J.G., Spencer, D.C. 2001. Future challenges and opportunities for agricultural R\&D in the semi-arid tropics. International Crops Research Institute for the Semi-Arid tropics, Patanchero India.

Sabino, A. 1990. As estruturas de conservação do solo e água em Cabo Verde e a quantificação dos impactos na área do Watershed Development Project (Ilha de Santiago). In Proceedings of the $1^{\text {as }}$ Jornadas sobre Agricultura de Cabo Verde, Comunicações do Instituto de Investigação Científica Tropical, Série de Ciências Agrárias, Lisboa, Portugal, 23-25 de Outubro, p. 91-124.

Sadeghi, S.H.R., Azari M., Ghaderi Vangah, B. 2008. Field evaluation of hill slope erosion model (HEM) in Iran. Biosystem Engineering 99: 304-311.

Sanchez-Moreno, J.F., Jetten, V., Mannaerts, C.M., Tavares, J.P. 2014b. Selecting best mapping strategies for storm runoff modelling in a mountainous semi-arid area. Earth Surface Processes \& Landforms 39 (8): 1030-1048

Sanchez-Moreno, J.F., Mannaerts, C.M., Jetten, V. 2014a. Influence of topography on rainfall variability in Santiago Island, Cape Verde. International Journal of Climatology 34 (4): 1081-1097.

Sanchez-Moreno, J.F., Mannaerts, C.M., Jetten, V. 2014a. Rainfall erosivity mapping for Santiago Island, Cape Verde. Geoderma 217-218: 74-82.

Sawadogo, H., Bock, L., Lacroix, D., Zombré, N.P. 2008. Restauration des potentialités de sols dégradés à l'aide du zai et du compost dans le Yatenga (Burkina Faso). Biotechnologie, Agronomie, Société \& Environnement 12:279-290.

Schwab, G. O., Fangmeier, D. D., Elliot, W. J., Frevert, R. K. 1993. Soil and water conservation engineering. 507 pp. ISBN 0-471-59994-8.

Schwilch, G., Bachmann, F., de Graaff, J. 2012a. Decision support for selecting SLM technologies with stakeholders. Applied Geography 34: 86-98

Schwilch, G., Bachmann, F., Liniger, H.P. 2009. Appraising and selecting conservation measures to mitigate desertification and land degradation based on stakeholder participation and global best practices. Land Degradation \& Development 20: 308326.

Schwilch, G., Bestelmeyer, B., Bunning, S., Critchley, W., Herrick, J., Kellner, K., et al. 2011. 
Experiences in monitoring and assessment of sustainable land management. Land Degradation and Development 22: 214-225.

Schwilch, G., Hessel, R., Verzandvoort, S., Eds. 2012b. Desire for Greener Land. Options for Sustainable Land Management in Drylands. Centre for Development and Environment, University of Bern (CDE): Bern, Switzerland, ALTERRA-Wageningen UR, World Soil Information (ISRIC) and Technical Centre for Agriculture and Rural Cooperation (CTA): Wageningen, the Netherlands.

Sharma, A.R., Behera, U.K. 2010. Green leaf manuring with prunings of leucaena Leucocephala for nitrogen economy and improved productivity of mayze (Zea mays)-wheat (Triticum aestivum) cropping season. Nutrient Cycling in Agroecosystems 86: 39-52.

Smolikowski, B., Puig, H., Roose, E. 2001. Influence of soil protection techniques on runoff, erosion and plant production on semi-arid hillsides of Cabo Verde. Agriculture Ecosystem and Environment 87: 67-80.

Srinivasarao, C.H., Venkateswarlu, B., Lal, R., Singh, A.K., Kundu, S., Vittal, et al. 2014. Long-term manuring and fertilizer effects on depletion of soil organic stocks under Pearl millet-cluster vean-castor rotation in Western India. Land Degradation \& Development 25: 173-183.

Steinhilber, P., Salak, J. 2010. Plant tissue analysis. In Soil fertility guide series. University of Maryland College of Agriculture and natural resources. Maryland, USA.

Stringer, L.C., Fleskens, L., Reed, M.S. 2014. Participatory Evaluation of monitoring and Modelling of Sustainable Land management Technologies in Areas Prone to land Degradation. Environmental management 54: 1022-1042.

Stringer, L.C., Reed, M.S. 2007. Land degradation assessment in Southern Africa: Integrating local and scientific knowledge bases. Land Degradation \& Development 18: 99-116.

Stroosnijder, L. 1996. Modelling the effect of grazing on infiltration, runoff and primary production in the Sahel. Ecological Modelling 92: 79-88.

Stroosnijder, L. 2003. Technologies for improving Green Water use Efficiency in West Africa. Water Conservation Technologies for Sustainable Dryland Agriculture in SubSaharan Africa. Symposium and Workshop, Bloemfontein, South Africa.

Stroosnijder, L. 2009. Modifying land management in order to improve efficiency of rainwater use in the African highlands. Soil \& Tillage Research 103 (2): 247-256

Stroosnijder, L. 2009. Modifying land management in order to improve efficiency of rainwater use in the African highlands. Soil \& Tillage Research 103 (2): 247-256

Stroosnijder, L., Moore, D., Alharbi, A., Argaman, E., Biazin, B., van den Elsen, E. 2012. Improving water use efficiency in drylands. Current Opinion in Environmental Sustainability 4: 1-10.

Tan Z.X., Lal, R., Wiebe, K. D. 2005. Global Soil Nutrient Depletion and Yield Reduction. Journal of Sustainable Agriculture 26 (1).

Tanveer, S.K., Zhang, J., Lu, X., Wen, X., Wu, W., Liu, Y. and Liao, Y. 2014. Effect of Corn Residue Mulch and N Fertilizer Application on Nitrous Oxide (N2O) Emission and Wheat Crop Productivity under Rain-fed Condition of Loess Plateau China. 
International J. Agric. Biol. 16: 505-512.

Tavares, J. 2010. L'érosion des sols au Cap Vert: une étude des processus et la Quantification à l'échelle des trois bassins versants de l'île de Santiago. Ph.D. Thesis, Bourgogne University, Dijon, France. p. 226

Tavares, J., Amiotte-Suchet, P. 2007. Rainfall erosion risk mapping in volcanic soils of Santiago Island, Cabo Verde Archipelago. African Geoscience Review 14: 399-414.

Tavares, J.P., Baptista, I., Ferreira, A.D., Amiotte-Suchet, P, Coelho, C., Gomes, et al. 2015. Assessment and mapping of sensitive area to desertification in an insular sahelian mountain region - case study of the Ribeira Seca Watershed, Cabo Verde". Catena 128:214-223.

Tavares, J.P., Ferreira, A.D., Reis, E.A., Baptista, I., Amoros, R., Costa, L.R., et al. 2014. Appraising and selecting strategies to combat and mitigate desertification based on stakeholder knowledge and global best practices in Cape Verde archipelago. Land Degradation \& Development 25: 45-57

Tenge, A.J., de Graaff, J., Hella, J.P. 2005. Financial efficiency of major soil and water conservation measures in West Usambara highlands, Tanzania. Applied Geography 25:348-366

Tenge, A.J., Okoba, B.O., Sterk, G. 2007. Participatory soil and water conservation planning using a financial analysis tool in the West Usambara highlands of Tanzania. Land Degradation \& Development 18: 321-337

Tesfaye, M.A., Negatu, W., Brouwer, R., van der Zaag, P. 2014. Understanding soil conservation decision of farmers in the Gedeb watershed, Ethiopia. Land Degradation \& Development 25: 71-79.

Tesfaye, M.A., Bravo-Oviedo, A., Bravo, F., Kidane, B., Bekele, K., Sertse, D. 2015. Selection of tree species and soil management for simultaneous fuelwood production and soil rehabilitation in the Ethiopian central highlands. Land Degradation \& Development 26 (7): 665-679.

Teshome, A., Rolker, D., De Graaff, J. 2013. Financial viability of soil and water conservation technologies in Northwestern Ethiopian highlands. Applied Geography 37: 139-149.

Thapa, G. B., Yila. O. M. 2012. Farmers' land management practices and status of agricultural land in the Jos Plateau, Nigeria. Land Degradation \& Development 23: 263- 277.

Tiscareno-Lopez, M., Velasquez-Valle, M., Salinas-Garcia, J., Baez-Gonzalez, A.D. 2004. Nitrogen and organic matter losses in no till corn cropping systems. Journal of the American Water Resources Association (JAWRA) 40: 401-408.

Turner, N.C. 2004. Agronomic options for improving rainfall-use efficiency of crops in dryland farming systems. Journal of experimental botany, 55, 407, Water saving Agriculture Special Issue: 2413-2425.

UNCCD. 2012. Desertification Land Degradation \& Drought - Some global facts and figures. http://unccd.int/lists/SiteDocumentLibrary/WDCD/DLDD/\%20Facts.pdf.

UNCCD. 2013a. United Nations Convention to Combat Desertification. The Economics of Desertification, Land Degradation and Drought: Methodologies and Analysis for 
Decision-Making. Background document. UNCCD 2nd Scientific Conference. http://2sc.unccd.int. Assessed in March 2015.

UNCCD. 2013b. United Nations Convention to Combat Desertification (UNCCD).

Decision8/COP11. Available at:

ww.unccd.int/Lists/SiteDocumentLibrary/Rio+20/IWG\%20on\%20rio\%2020/Decisio n\%208-COP11.pdf

UNCSD. 2012. Report on the United Nations Conference on Sustainable Development. www.uncsd2012.org. Assessed March 2015.

UN-MDG. 2006. United nations Millennium Development Goals. www.un.org/milleniumgoals/environ.shtml. Assessed March 2015.

UNU-INWEH (United Nations University). 2011. Guidelines for the Preparations and Reporting on Globally Relevant SLM Impact Indicators for Project Level Monitoring, UNU-INWEH: Hamilton, ON, Canada.

Varela, A.C. 2012. Avaliação do impacto das técnicas de conservação de solo e água na produção agrícola pluvial e na qualidade do solo: Estudo de caso da bacia hidrográfica da Ribeira Seca, Santiago. Master's Thesis, Universidade de Cabo Verde/Universidade Técnica de Lisboa (UniCV/ISA-UTL), Praia, Cabo Verde.

Wakeyo, M.B., Gardebroek, C. 2013. Does water harvesting induce fertilizer use among smallholders? Evidence from Ethiopia. Agricultural Systems 114:54-63

Wakindiki, C., Ben-Hur, M. 2004. Indigenous soil and water conservation techniques: Effects on runoff, erosion, and crop yields under semi-arid conditions. Australian Journal of Soil Research 40: 367-379.

Warner, K., Afifi, T., Henry, K., Rawe, T., Smith, C., de Sherbinin, A. 2013. Where the Rain Falls: Climate Change, Food and Livelihood Security, and Migration. Global Policy Report of the Where the Rain Falls Project. Bonn: UNU and CARE. A background paper prepared for the 11th Coordination Meeting on International Migration, New York, 21-22 February 2013.

Willy, D. K., Holm-Müller K. 2013. Social influence and collective action effects on farm level soil conservation effort in rural Kenya. Ecological Economics 90: 94-103.

Wischmeier, W.H, Smith.D.D. 1978. Predicting rainfall erosion losses - a guide to conservation planning. Agriculture Handbooks 537. US Deptartment of Agriculture, Washington, DC.

Wischmeier, W.H., Smith, D.D. 1965. Predicting rainfall-erosion Losses from cropland east of the Rocky Mountains. Agriculture handbook No.282, USDA, Washington, DC.

WOCAT, 2007a. Where the land is greener - Case studies and analysis of soil and water conservation initiatives worldwide. Editors: Hanspeter Liniger and William Critchley.

WOCAT. 2007b. World Overview of Conservation Approaches and Technologies. Where the Land is Greener-Case Studies and Analysis of Soil and Water Conservation Initiatives Worldwide; Liniger, H.P., Critchley, W., Eds. Technical Centre for Agriculture and Rural Cooperation (CTA): Wageningen, The Netherlands; Food and Agriculture Organization (FAO): Rome, Italy; United Nations Environment Programme (UNEP): Nairobi, Kenya; Centre for Development and Environment 
(CDE), University of Berne: Berne, Switzerland.

WOCAT. 2008. World Overview of Conservation Approaches and Technologies Questionnaires on SLM technologies and approaches (basic). In A Framework for the Evaluation of Sustainable Land Management (Revised), Liniger, H.P., Schwilch, G., Meckdachi Studer, R., Hauert, C., van Lynden, G., Critchley, W., Eds., Centre for Development and Environment, Institute of Geography, University of Berne: Berne, Switzerland.

Wolton, R.J., Pollard R.A., Goodwin, A., Norton, I. 2014. Regulatory services delivered by hedges: the evidence base. Report of Defra project LM0106. p99.

World Bank. World Development Report 2000/200. 2000. Attacking Poverty, World Bank: Washington, DC, USA.

World Meteorological Organization (WMO). 2005. Climate and Land Degradation. WMONo. 989. ISBN 92-63-10989-3. Geneva, Switzerland.

WSR. 2015. Status of the World's Soil Resources - Summary Report. Working document of the Intergovernmental Technical Panel on Soils (ITPS). FAO, Rome, Italy.

$\mathrm{Wu}$, W., Ma, B. 2015. Integrated nutrient management (INM) for sustaining crop productivity and reducing environmental impact: A review. Science of Total Environment 512-513: 515-427.

Xia, L., Hoermann, G., Ma, L., Yang, L. 2013. Reducing nitrogen and phosphorus from arable slope land with contour hedgerow and perennial alfalfa mulching in Three Gorges Area, China. Catena 110: 86-94.

Xie, L.W., Zhong, J., Chen, F.F., Cao, F.X., Li, J.J., Wu, L.C. 2015 Evaluation of soil fertility in the succession of karst rocky desertification using principal component analysis. Solid Earth 6 (2): 515-524.

$\mathrm{Xu}$, E.Q., Zhang, H.Q. 2014. Characterization and interaction of driving factors in karst rocky desertification: A case study from Changshun, China. Solid Earth 5 (2): 13291340.

Xu, Q. X., Wang, T. W., CAI, C. F., Li, Z.X., SHI, Z. H. 2012. Effects of soil conservation on soil properties of citrus orchards in the Three-Gorges Area, China. Land Degradation \& Development 23: $34-42$.

Zhang, S., Zhang, X., Ruffman, X., Liu, X., Yang, J. 2011. Influence of topography and land management on soil nutrient variability in Northeast China. Nutrient Cycling in Agroecosystems 89 (3): 427-438.

Zhao, G., Mu, X., Wen, Z., Wang, F., Gao, P. 2013. Soil erosion, conservation, and Ecoenvironment changes in the Loess Plateau of China. Land Degradation \& Development 24: 499- 510.

Zheng Mingguo, Cai Qiangguo, Chen Hao, 2007. Effect of vegetation on runoff-sediment yield relationship at spatial scales in hilly areas of the Loess Plateau, North China. Acta Ecologica Sinica 27(9): 3572-3581.

Zobisch, M. A., Richter, C., Heiligtag, B., Schlott, R. 1995. Nutrient losses from cropland in the central highlands of Kenya due to surface runoff and soil erosion. Soil and tillage Res. 33: 109-116. 
Zobisch, M. A., Richter, c., Heiligtag, B., Schlott, R. 1995. Nutrient losses from cropland in the central highlands of Kenya due to surface runoff and soil erosion. Soil and tillage Research 33: 109-116.

Zougmoré, R., Jalloh, A., Tioro, A. 2014. Climate-smart soil water and nutrient management options in semi-arid West Africa: a review of evidence and analysis of stone bunds and zaï techniques. Agriculture \& Food Security 3:16.

Zougmore, R., Mando, A., Ringersma, J., Stroosnijder, L. 2003a. Effect of combined water and nutrient management on runoff and sorghum yield in semi-arid Burkina Faso. Soil Use and Management 19: 257-264.

Zougmoré, R., Mando, A., Stroosnijder, L. 2009. Soil Nutrient and Sediment Loss as Affected By Erosion Barriers and Nutrient Source in Semi-Arid Burkina Faso. Arid Land Research and Management 23: 85-101

Zougmore, R., Mando, A., Stroosnijder, L., Ouédraogo, E. 2004. Economic benefits of combining soil and water conservation measures with nutrient management in semi-arid Burkina Faso. Nutrient Cycling in Agroecosystems 70: 261-269.

Zougmoré, R.B., Zida, Z., Kambou, N.F. 2003b. Role of nutrient amendments in the success of half-moon soil and water conservation practice in semi-arid Burkina Faso. Soil Tillage Research 71:143-149. 


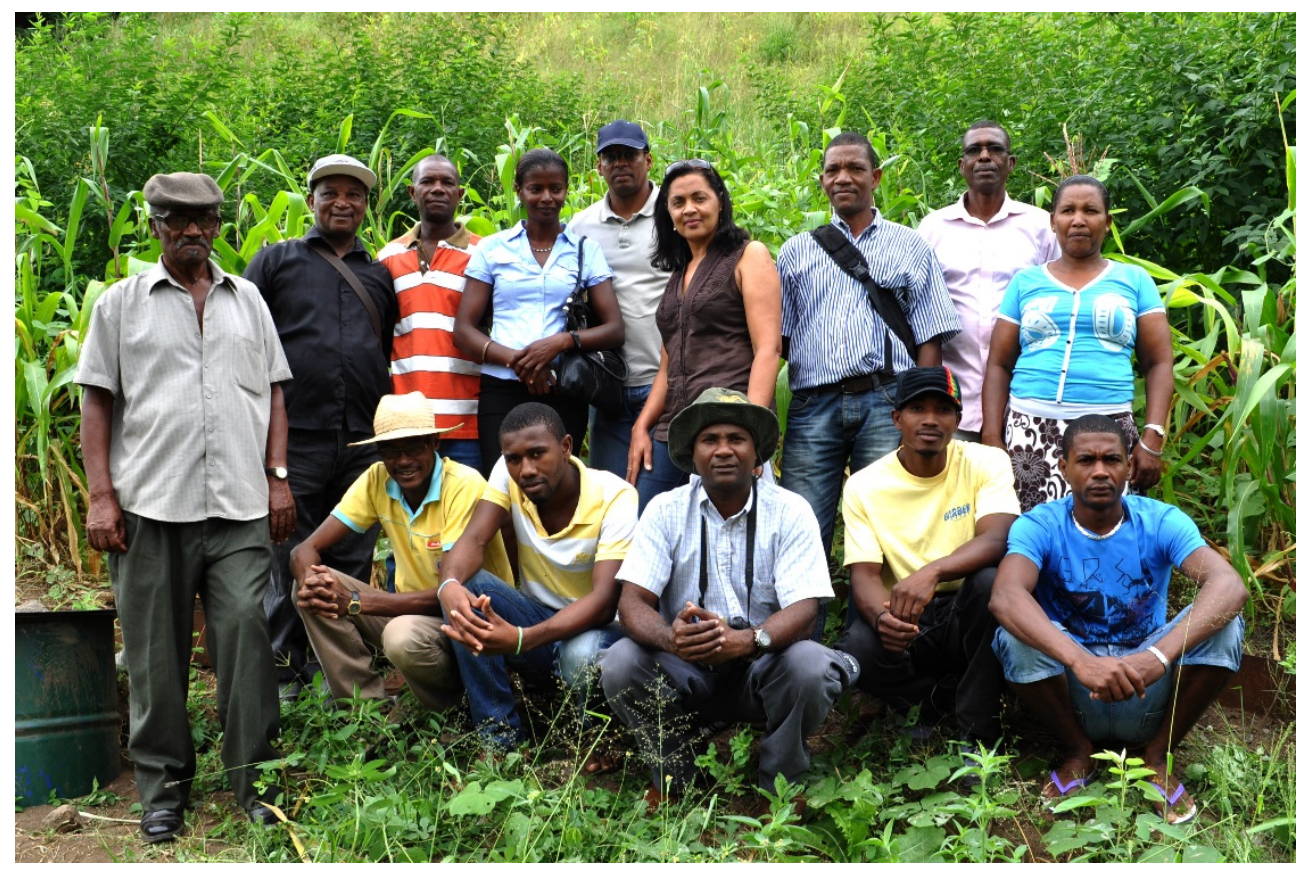




\section{English summary}

Soil and land degradation poses a great challenge for sustainable development worldwide. In Cabo Verde, severe land degradation has strongly affected both people's livelihood and the environment. Dryland food production in Cabo Verde is challenged by steep slopes, inadequate practices, irregular intense rain, recurrent droughts, high runoff rates, severe soil erosion and declining soil fertility, leading to the inefficient use of rainwater. Despite the enormous investment in soil and water conservation measures (SWC), which are visible throughout the landscape, land degradation due to water erosion is still rife and dryland crop productivity remains low. Sustainable land management (SLM) techniques that reduce runoff, erosion and nutrient loss are the key to mitigating/preventing land degradation and assuring long-term soil productivity.

Model evaluation of SLM technologies informs stakeholders regarding the spatial extent and regional impact of the technologies; thus enhancing their understanding of the technologies. The PESERA-DESMICE modelling approach offers a methodology to assess the biophysical and socio-economic benefits of SLM technologies against a local baseline condition and their potential application at larger scale.

This thesis aimed to investigate soil and water management techniques for Cabo-Verdean dryland farming systems to increase the efficiency of rainwater and crop yield, combining traditional and scientific knowledge in a field-based participatory approach. Field experiments were conducted in different agro-ecological zones, on slopes with different gradients and soil with different texture, during two growing seasons in the Ribeira Seca watershed, Santiago Island. The objective of the field experiments was to evaluate the effects of water conservation techniques (mulching of crop residue, soil surfactant and pigeon-pea hedges) combined with organic amendments (compost and animal or green manure) on runoff, erosion, soil nutrients and crop yield.

Following the general introduction (chapter 1), chapter 2 reviews the national strategies towards building resilience against the harsh environmental conditions, analyses the state of land degradation and its drivers, surveys the existing soil and water conservation measures, and assesses their effectiveness against land degradation and in supporting people's livelihoods. This chapter brings together insights from literature and policy review, field survey and participatory assessment in the Ribeira Seca Watershed through a 
concerted approach devised by the DESIRE project. The analysis allows us to infer that the relative success of Cabo Verde in tackling desertification and rural poverty is due to an integrated governance strategy that comprises awareness raising, institutional framework development, financial resource allocation, capacity building, and active participation of rural communities. This chapter provides a panoramic view of the importance of SWC measures for Cabo Verde drylands and recommends further specific, science-based assessment of the biophysical and socioeconomic impact of SLM and potential for upscaling using the "Desire approach".

Given the key roles of SLM techniques in reducing erosion and runoff, chapter 3 first discusses the participatory approach used in selecting the soil and water conservation techniques that are field-tested in this research and, then, evaluates the effects of the selected water conservation techniques combined with organic amendments on the generation of runoff and soil loss from rain-fed agricultural fields compared with traditional farmers' practices. The chapter also discusses the main factors influencing runoff and soil loss in semiarid dryland hilly areas, including the degree of soil cover, rainfall amount and erosivity, slope and soil infiltration rate. Runoff was significantly reduced only with the treatments containing mulch on slopes $>10 \%$ and in the treatment containing surfactant and organic amendment on slopes $<10 \%$. Erosion highly and positively correlated with runoff. Observed soil erosion rates were highest for the siltyclay-loam soil, followed by the sandy-loam soil and the loamy-soil, reaching a maximum value of 17 ton per hectare in the traditional practice, but were reduced by more than $50 \%$ with the soil conservation techniques. Mulch with pigeon-pea combined with an organic amendment almost eliminated runoff and erosion from agricultural fields even on steep slopes, contributing to improved use of rainwater at the plot level. The chapter recommends that SLM techniques, such as a combination of mulching, pigeon-pea hedges and an organic amendment, be advocated and promoted for the semiarid hillsides of Cabo Verde prone to erosion to increase rainwater-use and to prevent further soil degradation.

As soil erosion, runoff and related nutrient losses constitute a high risk to soil fertility in Cabo Verde drylands, chapter 4 focuses on the effects of the techniques tested in chapter 3 on erosion and runoff related nutrient losses $\left(\mathrm{NO}_{3}-\mathrm{N}\right.$ and $\left.\mathrm{PO}_{4}-\mathrm{P}\right)$ and on crop productivity. The traditional system lost significantly higher amounts of both $\mathrm{NO}_{3}-\mathrm{N}$ and $\mathrm{PO}_{4}-\mathrm{P}$ than the tested SLM techniques, with the combination of crop-residue mulch with organic amendment and (cross-slope) pigeon-pea hedges reducing soil loss, runoff and nutrient losses to nearly a $100 \%$. The loss of nutrients highly correlated with the amounts of runoff and eroded soil. Nutrient losses from the amended plots were low, while the significant losses from the traditional system could result in long-term nutrient depletion in the soil. The treatments did not consistently increase crop yield or biomass in all three 
sites, but the combination of organic amendment with soil surfactant increased both crop yield and biomass in some cases. The results lead to the conclusion that combining cropresidue mulch with organic amendment and runoff hedges is the best treatment for steep slope areas, although it is crucial to manage the pigeon-pea (runoff) hedges to achieve higher maize yield. For flatter areas with deeper soils, the combination of organic amendment with soil surfactant could be a less expensive and effective choice. Hence, this chapter identifies and recommends SLM techniques to prevent nutrient depletion, improve dryland crop yield and avoid further land degradation due to erosion by water, both in steep slope areas and flatter areas.

With chapters 3 and 4 demonstrating potential of SLM techniques, but also significant spatial-temporal yield variability, chapter 5 considers the PESERA-DESMICE modelling approach to capture a greater range of climatic conditions and evaluate the biophysical and socio-economic benefits of the most promising SLM technique - residue mulch combined with pigeon-pea hedges and an organic amendment (T3) against the traditional baseline practice of maize-bean intercropping (TO). It also evaluates the potential for upscaling the selected technique at Island scale.

From stations in semi-arid and sub humid climates, long-term historic rainfall statistics allowed construction of 50-year rainfall realizations providing a unique time-series of rainfall scenarios and an envelope of the potential biomass production. Such an envelope of potential yield helps express the agricultural risk associated with climate variability and the potential of the conservation measures to absorb the risk, highlighting the uncertainty of a given crop yield being achieved in any particular year. T3 elevates yield under both sub-humid and semi-arid climates with greater security for sub-humid areas even though risk of crop failure still exists. The T3 technology offered good potential to increase yields by $20 \%$ in $42 \%$ of the area and reduce erosion by $8.6 \mathrm{Mg} \mathrm{ha}^{-1}$, but in terms of cost effectiveness, it might be prohibitively expensive for farmers lacking inputs. The findings can directly inform policy options or influence adoption of conservation measures under the climatic variability of the Cabo Verde drylands and resilience to future climate change.

The thesis ends with a synthesis (Chapter 6) that presents the research findings, highlights the new contributions made to the current scientific debates on Climate-Smart Agriculture (CSA) technologies for sub-Saharan Africa, sustainable intensification and land degradation neutrality. The technology combining mulch with pigeon-pea hedges and an organic source of nutrients can be a promising CSA practice that could be widely used by smallholder farmers in semiarid regions to maintain food production and secure farmers' livelihoods, while contributing to ecosystem services by storing water in the soil. The synthesis also provides directions for further research and concludes with policy 
recommendations for optimizing soil and water management on hilly drylands to prevent further degradation and to contribute to sustainable intensification.

Indeed, this thesis presents alternative options to support moving from degrading and unproductive land management practices towards a more sustainable land intensification in hilly drylands through SLM techniques and approaches that reduce runoff and soil loss, increase crop nutrient and crop productivity, ultimately contributing to the adaptation to climate change, food insecurity and land degradation neutrality in Cabo Verde. 


\section{Acknowledgement}

As I reach the end of this long journey, I find myself thinking and agreeing with a PhD proposition of a friend that said, "A PhD is a joint endeavour of so many contributors where, in the end, only one is awarded a diploma". I wished it would be possible to award a gratitude certificate to all the people that contributed to the success of this thesis, to show my appreciation, since words may be too vague. This accomplishment would not have been possible without the valuable contribution of so many people (some not knowing it) at different level, scale, nature and dimension. Not meaning to underestimate or excluding the ones not mentioned here, I would like to express here my deep appreciation and gratitude to the following people and Institutions:

My promoter, Coen Ritsema, for accepting me as student, for helping with the proposal, for encouragement and excellent, sharp ideas. My deep appreciation to my co-promoter and supervisor, Violette Geissen, for her guidance in writing and statistical analysis, daily supervision and friendship. Thank you Coen and Violette for being there for me. My gratitude to Luuk Fleskens for the precious assistance in writing and revising some chapters of the thesis and co-authoring two of the papers. My thanks to Brian Irvine, from Leeds University, for his input with the PESERA modelling and co-authoring one of the articles.

António Querido and António D. Ferreira, members of my supervising team for their support, guidance and friendship.

The Netherland fellowship program for high education (NUFFIC) for granting me the PhD fellowship.

The Instituto Nacional de Investigação e Desenvolvimento Agrária of Cabo Verde (INIDA), headed first by Mr. Isildo Gomes, followed by Mrs. Aline Monteiro and Mrs. Angela Moreno, for allowing me to pursue the degree, granting my salary during the periods in the Netherland and making available the field and laboratory conditions to carry out the research. 
The farmers of Ribeira Seca for their collaboration in the field trials and the workshops, particularly the ones that also made available their field for the experiments (Jaime, Zé Luis, Lamine).

My colleagues at INIDA: Samuel Gomes, Antonio Fortes, Jacques Tavares, José Teixeira, Zenaida, Amarildo and Balbina for exchanging of ideas, moral support, assistance with fieldwork and / or laboratory analysis. Special thank goes to João Moreno, Varela, Mário Jorge, Gerson and Tiló for their precious assistance with field work; and Viriato Firmino for his prompt and valuable help in formatting the figures.

All my relatives and friends in the Netherlands (Rotterdam), particularly, tio Herculano, Celeste, Laila, Sy, Djunga, Mana Paula, Aldevino, Bia, Idá, Benvindo and all my cousins for their friendship and support, making me fell at home away from home. My long absences from home would have been unbearable without their affection.

My colleagues and friends at Wageningen University, particularly, Nádia, Celia, Akalu, Innocent, Edmond, Xiaomei, Kaveh, Sija, Karrar, Ammar, Renee Salm and many others for friendship, sharing of ideas and enjoyable moments spent together. I thank the members of the "Atlas gang" for keeping friendship within the group. My good friends Sabarmate Tiki and Maria Pereira (São) for the nice friendship, long walks in Wageningen, long talks and sharing Cabo-Verdean, Indian and Portuguese meals. Célia and Bruno for their hospitality and friendship during my last stay in Wageningen.

Professor Leo Stroosnijder, the former LDD chair group, for giving me pragmatic ideas for the proposal. Demie Moore, for the English editing of some of the chapters and friendship; Klaas Oostindie for helping with some figures and for assembling and formatting the thesis.

Marnella van der Tol and Annelies Bunte, for their efficiency in providing timely administrative arrangements and for their friendship. Marnella's smile brightens everyone's day.

My loving mother Marcelina, my dear sisters (Alzira, Lurena, Carmen, Ana Paula) and brothers (Alcídio, Uca, Beto, Vlá) for their endless love and unconditional support even when they did not fully understand why I still needed to study more for an advanced degree. Their love and support were fundamental to keep my strength and emotional equilibrium. 
My housekeeper for taking care of my house and family during my several absences along these years. Zenaida, I highly appreciate your caring and dedication to my family.

Finally, I give my appreciation and love to my husband, Aristides Costa (Tito), who supported and believed in me, even when I doubted myself, and stayed with me through my countless pleas of "Please be patient and wait until I'm finished!" Sorry for my bad moods. "Tito", thank you for your love, friendship, understanding and for handling the house during my absences. My love and apologies go to my children Melanie and Rodrigo for not being always available for them, particularly Rodrigo for my constant absences, missing important occasions like his birthdays and school events. Your understanding and support gave me strength to proceed. 


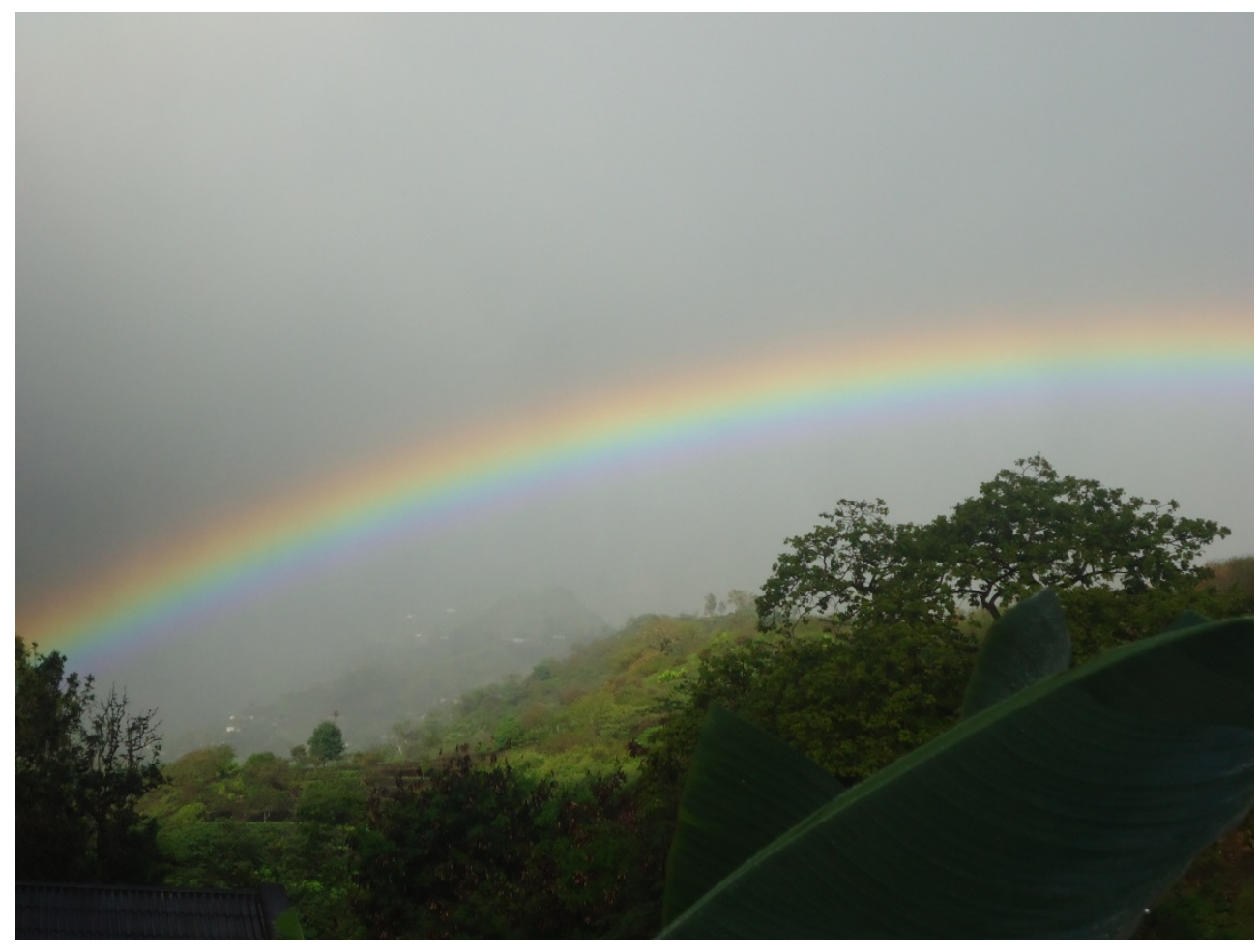




\section{Agradecimentos}

Ao chegar ao fim desta longa jornada, dei-me a pensar e a concordar com uma proposição de doutoramento de uma amiga que dizia, "PhD é um esforço conjunto de muitos contribuintes que, no final, é concedido um diploma só a uma pessoa". Gostaria que fosse possível atribuir um certificado de gratidão e reconhecimento a todas as pessoas que contribuíram para o sucesso desta tese, para mostrar o meu apreço, uma vez que palavras podem ser muito vagas. Essa conquista não teria sido possível sem a valiosa contribuição de tantas pessoas (algumas, sem saber) a diferente nível, escala, natureza e dimensão. Não querendo subestimar ou excluir as pessoas não mencionadas aqui, gostaria de expressar o meu profundo apreço e gratidão as seguintes pessoas e instituições:

Meu promotor, Coen Ritsema, por me aceitar como estudante, por ajudar com a proposta, pelo encorajamento e ideias excelentes e pragmáticas. Minha profunda gratidão a minha co-promotora e supervisora diária, Violette Geissen, pela sua orientação na escrita e análise estatística, supervisão diária e amizade. Obrigada, Coen e Violette, por terem estado sempre do meu lado e me apoiarem. Minha gratidão ao Luuk Fleskens pela preciosa assistência na escrita e revisão de alguns capítulos da tese e pela coautoria em dois artigos científicos. Meus agradecimentos ao Brian Irvine, da Universidade de Leeds, pelo input no modelo PESERA e pela coautoria num dos artigos.

António Querido e António D. Ferreira, membros da equipa de supervisão, pelo apoio, assistência pontual e amizade.

O programa de bolsas para o ensino superior dos Países Baixos (NUFFIC) por me conceder a bolsa de doutoramento. Uma muito obrigada ao Governo Holandês.

O Instituto Nacional de Investigação e desenvolvimento Agrária de Cabo Verde (INIDA) na pessoa, primeiro, do Sr. Isildo Gomes, seguido pela Sra. Aline Rendall e Sra. Ângela Moreno, por me permitir continuar os estudos e por me garantirem o salário durante os períodos na Holanda.

Meus colegas do INIDA, Samuel Gomes, António Fortes, Jacques Tavares, José Teixeira, Zenaida, Amarildo e Balbina pelas trocas de ideias, apoio moral, assistência com trabalho de campo e / ou análise de laboratório. Agradecimento especial vai para João Moreno, 
Varela, Mário Jorge, Gerson e Tiló pela sua preciosa ajuda no trabalho de campo e Viriato Firmino pela valiosa ajuda na formatação de muitas figuras.

Os agricultores da Ribeira Seca que participaram nos ensaios de campo e nos workshops, particularmente os que disponibilizaram os campos para os ensaios em meio real (Jaime, Zé Luís e Lamine).

Todos os meus familiares e amigos na Holanda (Rotterdam), particularmente, tio Herculano, Celeste, Laila, Sy, Djunga, Mana Paula, Aldevino, Bia, Idá, Benvindo e os restantes primos pela amizade e apoio, fazendo com que eu me sentisse em casa, apesar de longe de casa. As minhas longas ausências de casa teriam sido insuportáveis sem o vosso carinho e acolhimento.

Meus colegas e amigos da Universidade de Wageningen, especialmente, Célia, Nádia, Akalu, Innocent, Edmond, Kaveh, Sija, Karrar, Ammar, Renee Salm e muitos outros pela amizade, troca de ideias e momentos divertidos passados juntos. Agradeço aos colegas do "Atlas Gang" por manterem a amizade no seio do grupo. Minhas grandes amigas, Sabarmate Tiki e Maria Pereira (São), pela bonita amizade, longas caminhadas em Wageningen, longas conversa e partilha de refeições Cabo-verdianas, Indianas e Portuguesas. Célia e Bruno pela amizade e acolhimento na minha última estadia em Wageningen.

Professor Leo Stroosnijder, ex-leader do grupo de pesquisa, pelas ideias pragmáticas dadas a quando da elaboração da proposta. Demie, pela revisão da língua inglesa em alguns dos capítulos e pela amizade; Klaas Oostindie pela assistência com figuras, montagem e formatação da tese.

Marnella van der Tol e Annelies Bunte, pela sua eficiência no fornecimento de arranjos administrativos oportunos e pela amizade. O sorriso da Marnella ilumina o dia de todos.

Minha adorável mãe (Marcelina), queridas irmãs (Alzira, Lurena, Carmen, Ana Paula) e irmãos (Alcídio, Uca, Beto e Vlá) pelo seu apoio, amor infinito e incondicional, mesmo quando não fazia sentido para eles o facto de eu querer estudar mais para obter um grau de formação mais avançado. O amor e apoio da minha família foram fundamentais para manter a minha força e equilíbrio emocional.

Minha empregada por cuidar da minha casa e da minha família durante as minhas ausências ao longo desses anos. Zenaida, muito obrigada pelo teu carinho e dedicação à minha família. 
Finalmente, expresso a minha gratidão e meu amor ao meu marido, Aristides Costa, que me apoiou e acreditou em mim, mesmo quando eu duvidei de mim mesma, e ficou do meu lado nos meus inúmeros apelos de "por favor, seja paciente e espere até eu terminar!" Peço desculpas pelo meu mau humor. "Tito", obrigada pelo teu amor, companheirismo, compreensão e por gerir a casa durante as minhas longas ausências. Meu amor e sinceras desculpas vão para os meus filhos, Melanie e Rodrigo, por eu não estar sempre disponível para eles, particularmente o Rodrigo, pelas minhas ausências constantes e não estar presente em ocasiões importantes como aniversários e eventos escolares. Obrigada, meus amores, pela vossa compreensão e encorajamento. 


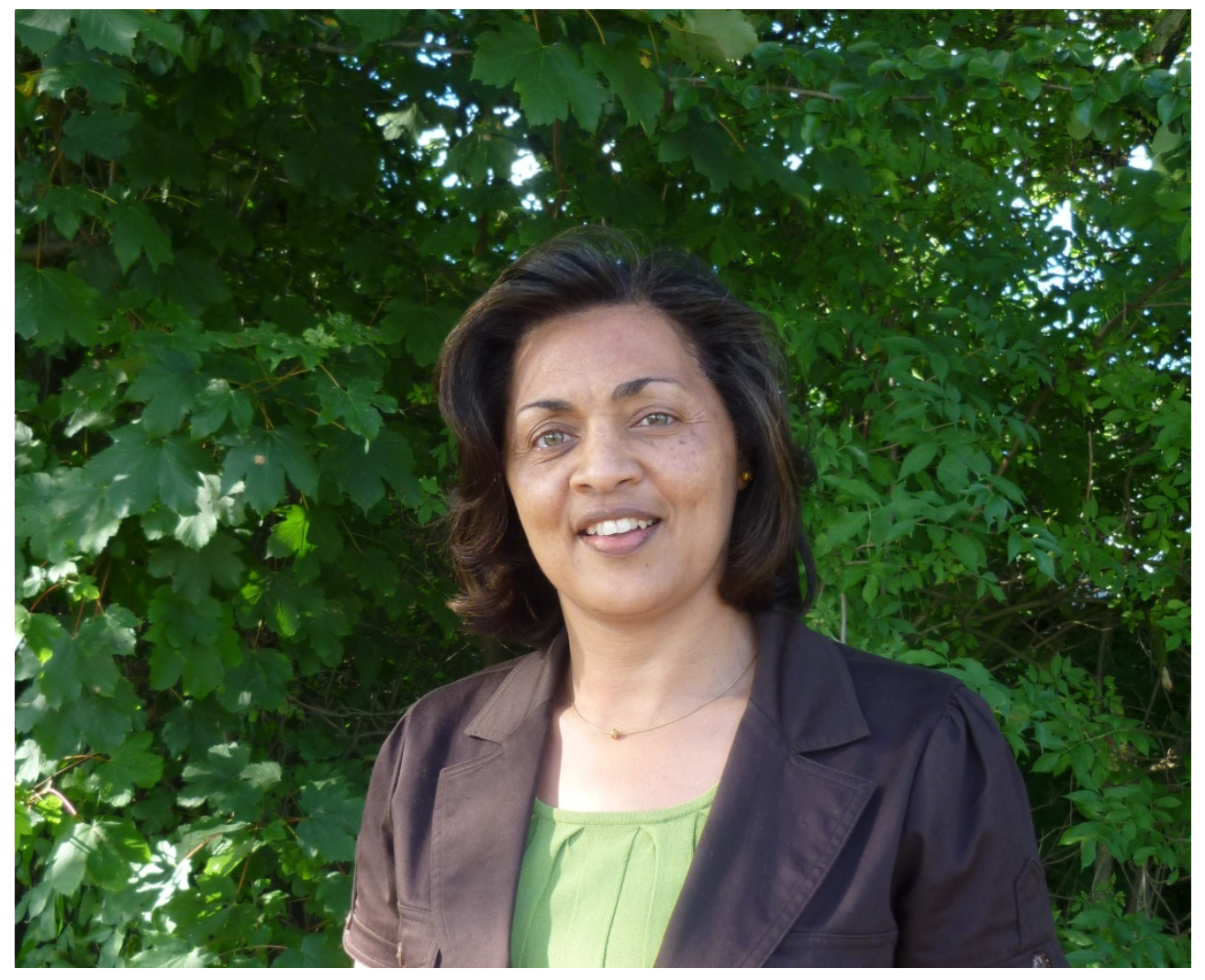




\section{Curriculum Vitae}

Isaurinda dos Santos Baptista Costa (Isaurinda Baptista) was born on February 18, 1963 in Santo Antão, Cabo Verde.

She has a bachelors' degree (BSc.) in agronomy from Colorado State University (US, 1988) and a Masters (MSc.) also in agronomy / soil science from the University of Georgia (USA, 1996).

Isaurinda is an agronomist specialized in soil fertility management and, currently, a senior researcher at the Instituto Nacional de Investigação e Desenvolvimento Agrário / National Institute of Agriculture Research and Development (INIDA) in Cabo Verde, where she has been working for 26 years. At INIDA, she was head of the Agriculture and Livestock Department (1997 to 2004) and scientific director (2004 to 2011), coordinating research in environmental sciences, agriculture, agro-economy and social sciences.

Isaurinda has participated in several international and regional projects, both as researcher and project coordinator. From 2007 to 2012, she coordinated the European funded project "DESIRE - Desertification Mitigation and Remediation of Land - a Global Approach for Local Solutions". From 1998 to 2002, she coordinated the implementation of the InterCRSP/West project "Improving and Sustaining Food and Raw Material Production in West Africa: Reversing Soil Acidification, Loss of Organic Matter and Erosive Runoff in Food Production Systems" (collaboration with the university of Hawaii).

While hosting a DESIRE annual meeting in 2009, she met Professor Coen Ritsema (DESIRE project coordinator) and showed her interest to pursue a PhD under the project framework, which he readily accepted and agreed to be the promotor. With the help of professor Ritsema and António Ferreira (from ESAC-Portugal) a PhD proposal was submitted to the Netherland Fellowship Foundation for High Education (NUFFIC), which granted the fellowship. In April 2010, Isaurinda joined the Land Degradation and Development research group (now Soil Physics and Land Management) at Wageningen University to conduct research on: "Innovative land management techniques to improve rainwater-use efficiency in Cabo Verde", a theme of crucial importance for that drought affected country. She aims to contribute for sustainable land management in the country, 
combating desertification and land degradation that are constant threat to the people's livelihoods.

She has participated and presented her work at several international events, such as the Agro Environ Symposium 2012 in Wageningen, NL; the General Assembly of the European Geosciences Union - EGU 2012 in Vienna, Austria; the LANDCON 1010 International Conference on "Combating land degradation in agricultural areas" in China; the workshop on "Launch of Global Soil Partnership in Western and Central Africa" in Accra, Ghana; and the DESIRE annual Plenary meetings that took place in Cabo Verde, Morocco, Turkey, China and Spain.

Parallel to her research, she has done consultancy on Climate change mitigation and adaptation, and on watershed management and development projects. She also has taught soils related courses at INIDA and the Public University of Cabo Verde.

Isaurinda is affiliated in the national professional Order of Cabo Verde Engineers (OECV) and, since 2013; she is both the focal point of the FAO Global Soil Partnership (GSP) and member of the Intergovernmental Technical Panel on Soil (ITPS), representing the African region.

Isaurinda is married and has two children: a 25-years old daughter and an 18-years old son.

Email contact: zau.baptista@gmail.com; ibaptista@inida.gov.cv

\section{Publications}

\section{Peer reviewed papers}

Baptista I, Ritsema CJ, Querido A, Ferreira AD, Geissen V. 2015. Improving rainwater-use in Cabo Verde drylands by reducing runoff and erosion. Geoderma, 237-238:283-297.

Baptista I, Fleskens L, Ritsema CJ, Querido A, Ferreira AD, Tavares J, Gomes S, Reis A, Varela A. 2015. Soil and water conservation strategies in Cape Verde (Cabo Verde in Portuguese) and their impacts on livelihoods: an overview from the Ribeira Seca Watershed. Land 4: 22-44

Baptista I, Ritsema C, Geissen V. 2015. Effect of integrated water-nutrient management strategies on soil erosion mediated nutrient loss and crop productivity in Cabo Verde drylands. PLOS ONE 10 (7): e0134244.

Baptista I, Irvine B, Fleskens L, Geissen V, Ritsema C. 2015. Assessing the biophysical impact and financial viability of soil management technologies under variable climate in 
Cabo Verde drylands: the PESERA-DESMICE approach. Land Degradation \& Development. Under review.

Tavares JP, Baptista I, Ferreira AD JD, Amiotte-Suchet P, Coelho C, Gomes S, et al. 2015. Assessment and mapping of sensitive area to desertification in an insular sahelian mountain region - case study of the Ribeira Seca Watershed, Cabo Verde". Catena 128: 214-223.

Tavares J, Ferreira AJD, Reis EA, Baptista I, Amoros R, Costa L, et al. 2013. Appraising and selecting strategies to combat and mitigate desertification based on stakeholder knowledge and global best practices in Cape Verde Archipelago. Land Degradation \& Development 25: 45-57.

\section{Book chapters}

Ferreira ADF, Tavares J, Baptista I, Coelho COA, Reis A, Varela L, Bentub J. 2013. Efficiency of overland and erosion mitigation techniques at Ribeira Seca, Santiago Island, Cabo Verde. In Overland Flow and Surface Runoff; Hydrological Science and Engineering Book Series; Wong, TSW, Ed., Nova Science Publishers, Inc. Singapore, pp. 113-135.

\section{Proceedings and Master thesis}

Baptista I. 1996. Use of animal manure to supply $\mathrm{N}$ to crops in Cape Verde. Master thesis. University of Georgia, Athens, USA. p 222

Baptista I. 2000. Effects of organic and inorganic fertilizers on the nutrient status and yield of dryland crops in Cape Verde. In Proceedings of the workshop of the InterCRSP project: Improving and sustaining food and row material Production in West Africa. Bamako. Mali Baptista I. 2003. Use of Leucaena leucocephla pruning as nitrogen source for Dryland crops in Cape Verde. In Technology adaptation under the interCRSP. A New model for international Collaborative Research and Technology Transfer: The NMR InterCRSP Project in West Africa. Bertelsen M and Brewster C Editors. Virginia Tech. 


\section{Certificate of the Netherlands Research School for the Socio-economic and Natural Sciences of the Environment (SENSE)}




\title{
SENSE
}

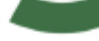

Netherlands Research School for the

Socio-Economic and Natural Sciences of the Environment

\section{I P L O M A}

For specialised PhD training

The Netherlands Research School for the

Socio-Economic and Natural Sciences of the Environment

(SENSE) declares that

\section{Isaurinda dos Santos Baptista Costa}

\author{
born on 18 February 1963 in Santo Antão, Cabo Verde
}

has successfully fulfilled all requirements of the

Educational Programme of SENSE.

Wageningen, 10 May 2016

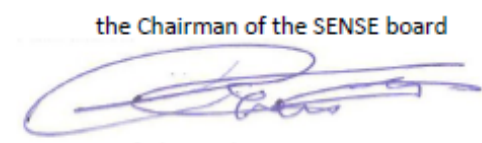

Prof. dr. Huub Rijnaarts the SENSE Director of Education

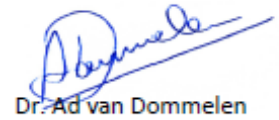

The SENSE Research school has been accredited by the Royal Netherlands Academy of Arts and sciences (KNAW)

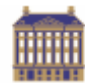

$\begin{array}{llllllllllllllllllllll}K & O & N & I & N & K & L & I & J & K & E & N & E & D & E & R & L & A & N & D & S & E\end{array}$

A K A D E M I E V A N W E T E N S C H A P P E N 


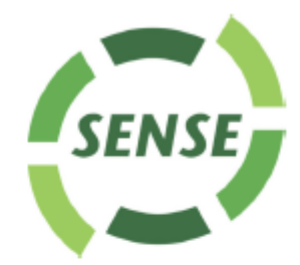

The SENSE Research School declares that Ms Isaurinda Baptista has successfully fulfilled all requirements of the Educational PhD Programme of SENSE with a work load of $56.8 \mathrm{EC}$, including the following activities:

\section{SENSE PhD Courses}

Environmental Research in Context (2010)

Soil ecology (2010)

Introduction to $\mathrm{R}$ for statistical analysis (2011)

Multivariate analysis (2012)

Research in Context Activity: 'Writing press communication for the Cabo Verde Info Journal of the Ministry of Rural Development (InfoMDR) and participation in a filmed documentary about desertification mitigation' (2014)

\section{Other PhD and Advanced MSc Courses}

Techniques for writing and presenting scientific papers, University Wageningen (2010)

Advanced statistics - Design of experiments, University Wageningen (2011)

Scientific Writing, University Wageningen (2013)

\section{Management and Didactic Skills Training}

- Co-organising the international symposium 'Brazil Cabo Verde - Environmental degradation in semiarid regions' (2010)

- Director of Research at the National Institute of Agricultural Research and Development (INIDA) (2010-2011), and member of the Institutional Management Board (2004-2011)

- Supervising MSc student with thesis entitled 'Impact assessment of soil and water conservation techniques on dryland crop yield and soil quality', Universidade de Cabo Verde (2011)

- Supervising three BSc students with thesis, Universidade de Cabo Verde (2011-2012)

- Teaching in the BSc course 'Soil fertility and fertilisation', Universidade de Cabo Verde (2012)

\section{OralPresentations}

- Assessment and mapping of desertification in an insular mountain region. International Conference on Combating Land Degradation in Agricultural Areas (LANDCON 1010), 11-15 October 2010, Xi'An, China

- Soil and Water conservation strategies and their impact on sustainable livelihoods. European Geosciences Union General Assembly (EGU), 22-27 April 2012, Vienna, Austria

- State of land Resources, needs and priorities in Cabo Verde. Launching of the Global soil Partnership-Western and Central Africa, 4-6 February 2013, Accra, Ghana

- Sustainable soil management and agricultural productivity: challenges and opportunities. International Agribusiness Fair of Cabo Verde, 30 May 2015, Praia, Cabo Verde

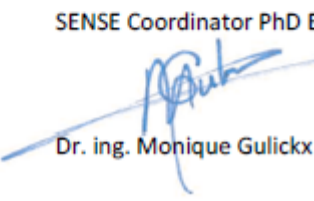

